\title{
Hans Urs von Balthasar wobec idealizmu niemieckiego Myśl chrześcijańska a refleksja filozoficzna
}


- 


\section{Marek Urban CSsR}

\section{Hans Urs von Balthasar wobec idealizmu niemieckiego Myśl chrześcijańska a refleksja filozoficzna}


Adiustacja i korekta

Paulina A. Lenar

Łamanie

Tomasz Sekunda

Projekt okładki

Małgorzata A. Batko

Publikacja finansowana $\mathrm{z}$ dotacji na utrzymanie potencjału badawczego Uniwersytetu Papieskiego Jana Pawła II w Krakowie przyznanej przez Ministra Nauki i Szkolnictwa Wyższego w roku 2016.

Copyright (C) 2017 by Uniwersytet Papieski Jana Pawła II w Krakowie

ISBN 978-83-7438-589-3 (wersja drukowana)

ISBN 978-83-7438-590-9 (wersja online)

DOI: http://dx.doi.org/10.15633/9788374385909

Uniwersytet Papieski Jana Pawła II w Krakowie

Wydawnictwo Naukowe

30-348 Kraków, ul. Bobrzyńskiego 10

tel. (12) 4226040

e-mail: wydawnictwo@upjp2.edu.pl

www.ksiegarnia.upjp2.edu.pl 
„Ideałem idealisty jest prześwietlenie siebie aż do krystalicznego świata konieczności, idei. Ideałem chrześcijanina jest odwrotne zachowanie: nie zważać na siebie, zapatrzeć się w Boga. Na tej drodze Bóg nie oszczędzi mu z pewnością wejrzenia w samego siebie, ale będzie to także przeciwieństwem idealistycznej refleksji. Demoniczność Hegla polega na tym, że próbował on zrównać bądź wykorzystać myśl chrześcijańską w refleksji filozoficznej”.

Hans Urs von Balthasar, Ziarno pszenicy. Aforyzmy

„Drogi kapłana i artysty przecinają się. Artysta kroczy, niedoceniany, wyśmiany przez tłum, w coraz większym stopniu wykraczając poza granice codzienności, a jednocześnie jego sztuka wyrasta z konwencji, przemieniając się w coś unikalnego, aż do granicy wyrazu: Michelangelo, Mozart, Hölderlin, Schubert. Na lodowcowych pustkowiach staje się łupem Boga. Kapłan natomiast kroczy od Boga, zanurzając się coraz głębiej w świat, dzieli się jak chleb, w końcu zostaje rozszarpany, jak Orfeusz przez menady. Rozdawanie siebie jest istotą obydwu, o to jedynie chodzi i to jest celem".

Hans Urs von Balthasar, Ziarno pszenicy. Aforyzmy 
- 


\section{Spis treści}

Wykaz skrótów ..................................................................... 9

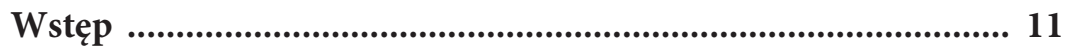

I. Filozoficzna twórczość Balthasara ....................................... 33

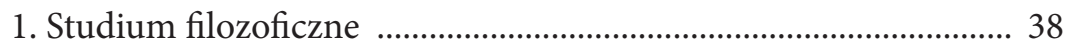

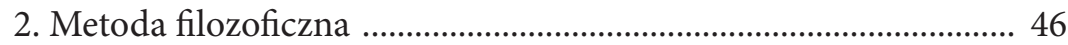

2.1. Myśl fenomenologiczna ....................................................... 47

3. Idealistyczna forma myślenia. Plotyn ............................................... 54

II. Eschatologia i mit. Apokalypse der deutschen Seele .............. 59

1. Apokalypse der deutschen Seele. Powstanie dzieła .......................... 60

1.1. Krytyczna analiza literacka dzieła .......................................... 64

1.2. Historia jako eschatologia. Pojęcie mitu ................................ 65

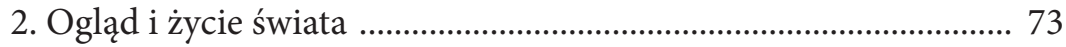

2.1. Dialektyka idealizmu niemieckiego ...................................... 75

3. Tragiczny dualizm. Immanuel Kant ................................................ 79

3.1. Filozofia praktyczna i moralność ......................................... 87

III. Systemy pokantowskie ...................................................... 95

1. Myślenie systemowe ......................................................................... 97

2. Struktura idealizmu pokantowskiego ............................................ 99

3. Mit Prometeusza …………………………………........................... 101 


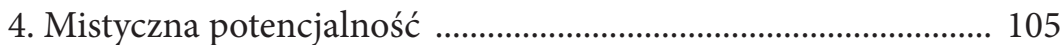

5. Johann Gottlieb Fichte. Wolność podmiotu a nieskończoność ... 108

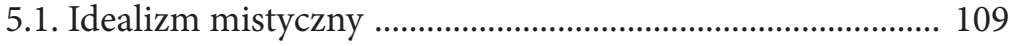

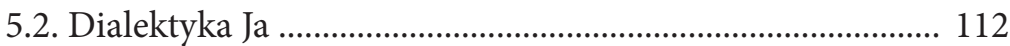

5.3. Nieskończoność i struktura egzystencjalna ....................... 116

5.4. Płaszczyzna religijna ....................................................... 120

6. Friedrich Wilhelm Joseph Schelling. Ogląd świata i filozofia przyrody ………………………………........................... 124

6.1. Odkrywanie Boga ............................................................... 125

6.2. Przestrzeń estetyki ................................................................ 130

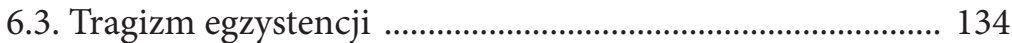

7. Georg Wilhelm Friedrich Hegel. Refleksja filozoficzna ............. 143

7.1. Hegel i kultura europejska ................................................... 146

7.2. W opozycji do Fichtego i Schellinga .................................... 148

7.3. Podmiot i przedmiot .............................................................. 151

7.4. Heglowska Apokalypse i ogień miłości ............................... 157

7.5. Chytrość rozumu a miłość ................................................ 162

8. W sporze z myśleniem idealistycznym ........................................ 167

IV. Filozoficzne piękno. Chwała ............................................... 173

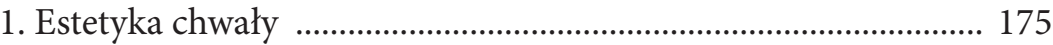

2. Historia doświadczenia chwały .................................................... 183

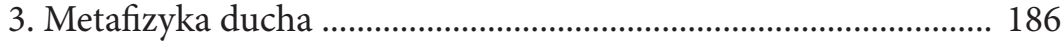

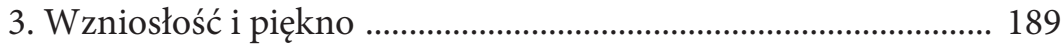

4. Chwała i dzieło sztuki .............................................................. 197

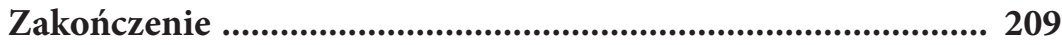

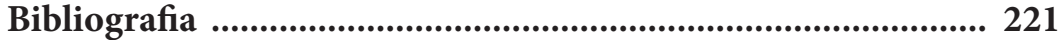

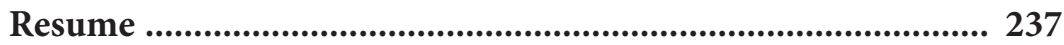

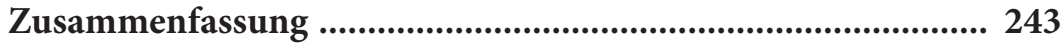

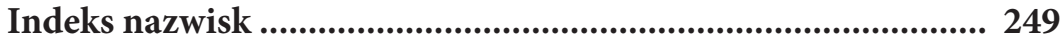




\section{Wykaz skrótów}

AP I Apokalypse der deutschen Seele. Studien zu einer Lehre von letzten Haltungen, Bd. I: Der deutsche Idealismus (1937), Studienausgabe der frühen Schriften unter der Leitung von Alois M. Haas, Johannes Verlag Einsiedeln, Freiburg 1998.

AP II Apokalypse der deutschen Seele. Studien zu einer Lehre von letzten Haltungen, Bd. II: Im Zeichen Nietzsches (1939), Studienausgabe der frühen Schriften unter der Leitung von Alois M. Haas, Johannes Verlag Einsiedeln, Freiburg 1998.

AP III Apokalypse der deutschen Seele. Studien zu einer Lehre von letzten Haltungen, Bd. III: Vergöttlichung des Todes (1939). Studienausgabe der frühen Schriften unter der Leitung von Alois M. Haas, Johannes Verlag Einsiedeln, Freiburg 1998.

CH I Chwała. Estetyka teologiczna I. Kontemplacja postaci, tłum. E. Marszał, J. Zakrzewski, WAM, Kraków 2008.

CH III/1/1 Chwata. Estetyka teologiczna III/1. Metafizyka, cz. 1: Starożytność, tłum. L. Łysień, WAM, Kraków 2011.

CH III/1/2 Chwała. Estetyka teologiczna III/1. Metafizyka, cz. 2: Nowożytność, tłum. L. Łysień, WAM, Kraków 2013.

OMD O moim dziele, tłum. M. Urban, Wydawnictwo M, Kraków 2004. 
$10 \quad * \quad$ Hans Urs von Balthasar wobec idealizmu niemieckiego

OZFK O zadaniach filozofii katolickiej w czasach wspótczesnych, tłum. M. Urban, WAM, Kraków 2003.

PW 1 Pisma wybrane, t. 1: Pisma filozoficzne, wybór i oprac. M. Urban, tłum. M. Urban, D. Jankowska, WAM, Kraków 2006.

PW 2 Pisma wybrane, t. 2: Pisma z zakresu sztuki i religii, wybór i oprac. M. Urban, tłum. M. Urban, D. Jankowska, WAM, Kraków 2007.

TL I Teologika, t. I: Prawda świata, tłum. J. Zychowicz, WAM, Kraków 2004.

TL II Teologika, t. II: Prawda Boga, tłum. J. Zychowicz, WAM, Kraków 2004.

TL III Teologika, t. III: Duch Prawdy, tłum. J. Zychowicz, WAM, Kraków 2005. 


\section{Wstęp}

W 1954 roku w jednym ze swych artykułów Hans Urs von Balthasar pisał: „Kto dziś opowie się za tym (a często się obecnie o tym słyszy i czyta), by Europa zbudowana na fundamencie chrześcijaństwa, które rozwinęło się zgodnie z własnymi prawami, nadal je pielęgnowała, walcząc za nie na śmierć i życie? Kto zagwarantuje, że skoro tak było do dzisiaj, będzie tak samo w przyszłości i że naprawdę niemożliwe jest odłączenie się od tych tradycji, bez których Europa nie będzie już Europą?"1. Można dziś za szwajcarskim teologiem i filozofem zapytać: czy istnieje jakieś prawo ciągłości historycznej, oparte na historycznym doświadczeniu, które pozwoliłoby uzasadnić lub z góry odrzucić dylemat: albo Europa chrześcijańska, albo żadna?

Czy odpowiedź na to pytanie ma wyrastać z myślenia, które odrzucałoby odpowiedzialność za przyszłość na prawach przeszłości, czy też raczej wypływa ono z wolności podejmowania decyzji całkowicie niezależnej od rozważań historycznych? Odpowiedzialność za bieg dziejów spoczywa przede wszystkim

${ }^{1}$ H.U. von Balthasar, Sur les Conditions d'une Culture, „La Revue de Culture Européenne" 1954, nr 4, s. 11-21, tutaj s. 11. (Jeśli w danych bibliograficznych nie podano inaczej, wszystkie przekłady cytowanych fragmentów prac obcojęzycznych nietłumaczonych dotąd na język polski, w tym również dzieł Balthasara, pochodzą od autora). 


\section{$12 \quad$ Hans Urs von Balthasar wobec idealizmu niemieckiego}

na człowieku, który będąc twórcą kultury i wydarzeń społecznych, swoim działaniem wpisuje się w historię. Dyskusja pomiędzy chrześcijaństwem a myślą filozoficzną jest ciągle aktualna i bez wątpienia stanowi część współczesnych sporów o właściwy obraz świata i najważniejsze kwestie dotyczące współistnienia wielu różnych światopoglądów i religii. W tę dyskusję o stanie myśli chrześcijańskiej wpisują się rozważania Hansa Ursa von Balthasara nad idealizmem niemieckim. Balthasarowskie myślenie wynikało bowiem nie tylko z troski o zrozumienie religijnego i intelektualnego obrazu dziejów Europy, ale tworzyło także przestrzeń do właściwego postrzegania zadań samej filozofii.

Początków zainteresowania problematyką idealizmu niemieckiego u Balthasara trzeba szukać już w czasie jego studiów germanistycznych w Wiedniu i Berlinie: „W Wiedniu nie studiowałem muzyki, lecz przede wszystkim germanistykę, i to, czego się tam nauczyłem, umieściłem później w centrum moich pism teologicznych: umiejętność dostrzegania, oceniania i interpretowania pewnej postaci (Gestalt), powiedzmy. Syntetyczne spojrzenie (w przeciwieństwie do krytycznego spojrzenia Kanta, czy analitycznego nauk przyrodniczych) i umiejętność dostrzegania tej postaci zawdzięczam temu, który nie odstąpił od widzenia, tworzenia i klasyfikowania wyłaniającej się z chaosu burzy i naporu żywej postaci: Goethemu. Jemu zawdzięczam decydujące narzędzie dla wszystkiego, co stworzyłem"2. Podczas studiów powstawały pierwsze zarysy konfrontacji świata chrześcijańskiego z myślą filozoficzną. Balthasar był świadomy faktu, że kultura niemiecka od wczesnego średniowiecza do nowożytności była kulturą chrześcijańską, ale z czasem coraz bardziej oddalała się

2 Tenże, Podziękowanie laureata Nagrody im. Wolfganga Amadeusza Mozarta wygłoszone 22 maja 1987 roku w Innsbrucku, w: E. Guerriero, Hans Urs von Balthasar. Monografia, tłum. M. Rodkiewicz, Wydawnictwo M, Kraków 2004, s. 397. 
od swoich chrześcijańskich korzeni. Idealizm niemiecki niósł ze sobą zsekularyzowane treści chrześcijańsko-teologiczne ${ }^{3}$. Rodziło się pytanie: „Jak wielcy tego świata, na których opiera się ta nowsza kultura, w głębi duszy, w swoim wnętrzu odnoszą się do chrześcijańskiego dziedzictwa: ci wszyscy, od Herdera i Lessinga, poprzez Kanta i idealistów, klasyków weimarskich, Jeana Paula, Hölderlina, Hebbla i Wagnera, Nietzschego, aż po filozofów życia, Hofmannsthala, Rilkego, Schelera? Prometeusz i Dionizos kontra Ukrzyżowany, ale czy oni sami też nie byli ukrzyżowani?"4

Powiązanie myśli filozoficznej z ideami chrześcijaństwa fascynowało Balthasara już u początków jego twórczości. Zdawał sobie sprawę z faktu, że utrzymanie wzajemnych, dialektycznych relacji stanowi wyzwanie dla całej filozofii. Świat postrzegany przez Balthasara był „nie dającym się zatrzymać rozpadem, ponieważ od Hölderlina już tylko krok do Nietzschego, od Hegla już tylko pół kroku do Feuerbacha i Marksa. A całkowita, nawet jeśli prymitywna i barbarzyńska, negacja chrześcijaństwa może być dla niektórych lepsza, niż cały dwuznaczny sens idealistycznego, »obojnackiego « świata (Zwitterwelt), w którym amalgamat chrześcijańsko-antychrześcijański stopił się tak nieodwracalnie, iż myślenie dialektyczne może oddać się wszelkim grom nieskończonej spekulacji, bez konieczności dojścia do jakichkolwiek konkretnych rezultatów" .

Przedzieranie się przez meandry literatury sprowokowało Balthasara do zadania pytania, jak wielcy przedstawiciele kultury niemieckiej ustosunkowują się do dziedzictwa chrześcijańskiego, a jednocześnie dawało nowe spojrzenie na wielkie postacie niemieckiej filozofii, które staną się gwiazdami rzucającymi światło na głębokie i szerokie myślenie całościowe: „Niektóre ze

\footnotetext{
${ }^{3}$ Por. tamże, s. 398.

4 Tamże, s. 397-398.

${ }^{5}$ OZFK, s. 42.
} 
starych gwiazd zachowały niesłabnącą siłę swego blasku: Platon, Hölderlin, przede wszystkim Goethe i Hegel, także kilku słów i gestów Nietzschego nie dało się już nigdy zapomnieć" .

Niestety, odpowiedź na to pytanie była niełatwa, bo wcześniej przez nikogo niepodejmowana, należało więc dochodzić do niej różnymi sposobami. Poszukiwania młodego studenta germanistyki zaowocowały próbą nowego, chrześcijańskiego spojrzenia najpierw na idealizm niemiecki. Próba ta, w opinii samego Balthasara, zdawała się przekraczać możliwości młodego człowieka, stała się jednak fundamentem późniejszego rozumienia bogatej formy myślenia idealistycznego. Jednocześnie stała się ona pierwszą egzemplifikacją tego, co Balthasar wyzna po kilku latach: „Pisząc, wyprzedza się niejako siebie samego w marzeniu o całości, w której chciałoby się bezpiecznie schronić własne fragmenty"”. Nową, dojrzałą formą myślenia i przezwyciężeniem idealizmu niemieckiego miała być w przyszłości pełna dynamiki i otwartości filozofia stawania się, wywodząca się od ojców Kościoła (przede wszystkim Orygenesa i Grzegorza z Nyssy) ${ }^{8}$.

W ten sposób pierwsze spojrzenie na filozofię idealizmu nie miało na celu jedynie opisowego, neutralnego przedstawienia poglądów poszczególnych myślicieli, ale nosiło wyraźny rys osądu i myśli krytycznej. Osąd ten wskazywał na ostateczne niepowodzenie wszelkiej myśli o charakterze czysto immanentnym. Dlatego Balthasar ceni Goethego jako „późnego arystotelika, którego niedająca się zbić z tropu obiektywność objęła również Tassa i Fausta i poradziła sobie z nimi, który każde drżenie duszy, każdy

${ }^{6}$ H.U. von Balthasar, Hans Urs von Balthasar przedstawia siebie, w: OMD, s. 10.

${ }^{7}$ Tenże, Krótki przewodnik po moich książkach, w: OMD, s. 15.

${ }^{8}$ Por. tamże, s. 21. 
rezonans wewnętrznej głębi wykorzystuje do tego, aby pieśni pochwalnej bytów nadać stosowniejszą, aktualną postać” 9 .

Twórcze kształtowanie się świata powinno być widoczne przede wszystkim jako ruch wyrażający wewnętrzną zdolność transcendowania. Transcendowanie to, stanowiące istotowy moment natury ludzkiej, winno ukazać zasadniczy cel człowieka: ostateczną postać bytu osobowego mającego swoje uzasadnienie w bycie absolutnym - Bogu. Zdaniem Balthasara, dotychczasowy bilans myśli nowożytnej jest negatywny i pełen sprzeczności. Negatywny, bo z punktu widzenia myśli czysto immanentnej zrozumienie ostatecznej postaci bytu człowieka jest niemożliwe. Pełen sprzeczności, bowiem zupełne przemienienie świata, przebóstwienie ziemi, kontrastuje z upadkiem, drogą donikąd. „Można dalej wysunąć problem, na ile wszystko, co w nowszych czasach nadaje sobie pozory filozofii religii niezależnej od chrześcijaństwa, w istocie rzeczy żywi się albo przejęciem, albo negacją chrześcijańskich idei dotyczących porządku nadnaturalnego. Niekończąca się dyskusja o wzajemnym stosunku chrześcijaństwa i idealizmu niemieckiego nadaje się szczególnie dobrze do zilustrowania tych spraw. Żadnego z wielkich idealistycznych filozofów i poetów nie można sobie nawet w najmniejszym stopniu wyobrazić bez chrześcijaństwa"10.

Dlatego musi się pojawić postulat filozofii uniwersalnej - obejmującej całość myślenia. Zadanie filozofii powinno polegać na tym, by nie ograniczyć się tylko do pewnej wybranej części ludzkiego ducha i myślenia, lecz by ująć całość rozumu ludzkiego wraz z wszelkimi jego możliwościami i konsekwencjami. Balthasar dostrzegał w myśleniu nowożytnym pewną skłonność do pełnego

9 Tamże, s. 31. Goethemu poświęca Balthasar wiele miejsca w różnych swoich pracach. Por. na ten temat np. AP, s. 407-514; CH III/1/2, s. 311374; Osobowość i forma, w: PW 1, s. 101-116.

${ }^{10}$ OZFK, s. $40-41$. 
sprzeczności ujmowania historii myśli europejskiej i jej rozwoju. Rozwój ten nabiera charakteru dialektycznego, postrzegane negatywnie wydarzenia otrzymuja pozytywne znaczenie dla przyszłości. Na horyzoncie Balthasarowskich rozważań pojawia się obraz krzyża, wyrażającego dialektykę życia i śmierci, niszczenie i budowanie nowych wartości oraz nowego rozumienia egzystencji. Ta znajduje wyraz w rozdarciu bytu, który chce przezwyciężyć wewnętrzne napięcie w pojednaniu (na wzór heglowskiej dialektyki) świata natury i ducha, a otwarty na „rzeczy ostateczne” odkryje całą prawdę o sobie samym ${ }^{11}$.

Horyzont filozoficznej myśli Balthasara wytyczają dwa kręgi, w które wpisuje się namysł nad idealizmem niemieckim. Pierwszy z nich sam opisuje w następujący sposób: „Próbowałem zatem zbudować filozofię i teologię, wychodząc od analogii, a więc nie od abstrakcyjnego bytu, lecz raczej od bytu spotykanego konkretnie w jego (nie kategorialnych, ale transcendentalnych) własnościach. Ponieważ transcendentalia władają całym bytem, muszą być także wewnętrzne względem siebie: to, co jest rzeczywiście prawdziwe, musi być również dobre i piękne, i musi stanowić jedno. Byt »ukazuje się", następuje epifania: w niej jest on piękny i uszczęśliwia nas. Ukazując się, oddaje się, daje się nam: jest dobry. A dając się, »wyraża się", odsłania samego siebie: jest prawdziwy (w sobie i w innym, któremu się objawia)"12. Drugi krąg tworzyło odniesienie człowieka do ludzkiego umysłu, który „musi być otwarty na nieskończone. W tym miejscu rozpoczyna się moja główna myśl. Powiedzmy jeszcze tylko wcześniej, że dawne pojęcie »metafizyka « oznacza akt przekraczania physis, zdaniem Greków obejmującej cały kosmos, którego częścią był człowiek.

${ }^{11}$ Por. A.M. Haas, Zum Geleit, w: H.U. von Balthasar, Apokalypse der deutschen Seele. Studien zu einer Lehre von letzten Haltungen, Bd. I, Johannes Verlag Einsiedeln, Freiburg 1988, s. XXXIX.

${ }^{12}$ H.U. von Balthasar, Spojrzenie wstecz, w: OMD, s. 82. 
Dla nas fizyka to coś innego, a mianowicie nauka o świecie materialnym. Kosmos dopełnia się dla nas w człowieku, który jest jednocześnie streszczeniem świata i jego przekraczaniem. Nasza filozofia będzie więc w istocie meta-antropologią, której podstawą są nie tylko nauki kosmologiczne, ale również antropologiczne, i która przewyższa je w kwestii bytu i istoty człowieka"13.

Celem niniejszej pracy nie jest dogłębna analiza zakreślonego tutaj horyzontu, ale zrozumienie stosunku Balthasara do idealizmu niemieckiego w kontekście całej jego myśli filozoficznej i religijnej. Konfrontacja $\mathrm{z}$ idealizmem niemieckim pozwalała mu ukazać ważkość zarówno rozumu filozoficznego, jak i refleksji nad przeżywaną wiarą. Ich wzajemną relację obrazuje postać człowieka o prometejskich rysach: odwagi i poświęcenia.

Stosunek Hansa Ursa von Balthasara do idealizmu niemieckiego jest ambiwalentny. $Z$ jednej strony bowiem ocenia on go bardzo pozytywnie, a nawet pozostaje pod wyraźnym wpływem jego zasadniczych idei. Z drugiej strony zaś ewidentnie się od niego dystansuje, poddając krytyce nawet jego zasadnicze cele. Wydaje się, że stosunek ten nie został do tej pory dokładnie przeanalizowany. W wielu opracowaniach na temat elementów filozoficznych w twórczości Balthasara i ich wpływu na myślenie teologiczne mówi się często o idealizmie niemieckim jako momencie pierwotnym i zarazem kluczowym w całokształcie myśli tego autora ${ }^{14}$. Ważkość tej kwestii ma zarówno aspekt historyczny, stano-

13 Tamże, s. 81.

${ }^{14}$ Por. np.: T.E. Oakes, Goethe, Nietzsche and the Encounter with German Idealism, w: Pattern of Redemption: the Theology of Hans Urs von Balthasar, Continuum, New York 1994; M. Bondeli, Mystische Potentialität. Hans Urs von Balthasar über den Weg von Kant zu Hegel, w: Letzte Haltungen. Hans Urs von Balthasars „Apokalypse der deutschen Seele” - neu gelesen, hrsg. von B. Hallensleben, G. Vergauwen, Academic Press-Paulusverlag, Freiburg 2006, s. 132-158; J. Disse, Metaphysik der Singularität. Eine Hinführung am Leitfaden der Philosophie Hans Urs von Balthasars, Passagen Verlag, Wien 1996; 
wi bowiem istotny początek twórczego myślenia Balthasara, jak i merytoryczny, bo ukazuje zasadniczy problem relacji człowieka do Boga, przewijający się w całej jego twórczości.

Przedmiotem poniższych rozważań nie mogą być szczegółowo wszystkie motywy Balthasarowskiej konfrontacji z idealizmem niemieckim. Co prawda w kręgu jego zainteresowań znajdują się wszyscy, którzy „starają się uratować tzw. "prawdę“ chrześcijaństwa, przenosząc ją w sferę ponad- lub pochrześcijańską: Lessing nie mniej niż Herder, Kant, Fichte, Schelling i Hegel, Goethe nie mniej niż Hölderlin czy Schiller"15, jednak centrum tych zainteresowań wydaje się stanowić myśl „trzech tytanów”: Fichtego, Schellinga i Hegla, którzy „myślą człowieka w całości Absolutu jako jego centrum"16.

Punktem wyjścia do namysłu nad idealizmem, w takim ambiwalentnym kontekście, jest zwrócenie uwagi na kategorię piękna, która zdaniem Balthasara wydaje się mocno zapomniana - zarówno przez nauki ścisłe, jak i humanistyczne, przede wszystkim przez religię i teologię. Próbę przywrócenia pięknu jego znaczenia powinna podjąć filozofia, dla której jest ono nie tyle początkowym momentem rozważań, ile punktem dojścia. „Piękno jest ostatnią rzeczywistością, na którą może ważyć się myślący rozum, ponieważ jako niepojęty blask otacza on podwójną gwiazdę prawdy i dobra oraz ich nierozerwalne odniesienie do siebie. Jest to najbardziej bezinteresowne piękno, bez którego dawny świat nie potrafił pojmować siebie, które jednak niezauważenie pożegnało się z nowym światem interesów, aby

E. Guerriero, Hans Urs von Balthasar. Monografia, dz. cyt.; P. Henrici, O filozofii Hansa Ursa von Balthasara, w: PW 1, s. 153-175.

15 OZFK, s. 41.

${ }^{16} \mathrm{CH}$ III/1/2, s. 497-498. 
pozostawić je ich żądzy i smutkowi. Religia już nie lubi i nie pielęgnuje tego piękna" 17 .

Balthasar jest przekonany, że w świecie pozbawionym piękna człowiek nie potrafi ani się modlić, ani kochać. Nie umie także dostrzec dobra, a skoro go nie dostrzega, nie będzie mógł go realizować. Ostatecznie zapomnienie o pięknie prowadzi do zapomnienia o bycie. Egzystencja ludzka pozostaje mroczna i niezrozumiała. Zadaniem myślącego człowieka jest podjęcie wysiłku przywrócenia tajemnicy ludzkiego istnienia. Dlatego też musi on pojąć, że do pewnych zadań nie jest już zdolny, lub zignorować wiedzę o braku własnych zdolności i zrozumieć, że nadszedł czas, by ponownie dostrzec prawdę całości, która jest żywą więzią między Bogiem i światem.

Odwieczne piękno ukazuje się w świecie pod widocznymi formami i daje się nam przede wszystkim w tajemnicy postaci lub obrazu $^{18}$. Tylko postać rości sobie prawo do pełnego imienia piękna i jest miejscem, w którym ukazuje się blask piękna odwiecznego. Balthasar postrzega piękno przede wszystkim jako podstawową obecność Boga w świecie i ludzkich dziejach. To właśnie w kategorii piękna Ten, który wydaje się Niewyrażalny, pozwala się niejako dostrzegalnie dotknąć.

Takie rozumienie, zmierzanie ku temu, co niewyrażalne i piękne ${ }^{19}$, przybliża Balthasara do religijnego nurtu idealizmu niemieckiego. Nurt ten widzi on jako cechę charakterystyczną wrażliwych

${ }^{17}$ CH I, s. 16.

${ }^{18}$ Por. tamże, s. 17.

${ }^{19}$ Balthasar otwarty jest na głębokie przeżycie związane z kategorią piękna, przeżycie, które wyrasta jakby ponad możliwości „ziemskiego doświadczenia”. „Podobnie nic nie będzie w stanie oderwać mnie również od Mozarta i największych dzieł Haydna, od tego ciągle nowego, przejmującego przeżycia, że istnieją rzeczy zbyt piękne dla naszego świata"; H.U. von Balthasar, Retrospektywa, w: OMD, s. 31. 
twórców idealizmu, którzy potrafili pokazać więź między pięknem a religią, czy też ogólniej: między sztuką a religią. Więź ta wynikała, jego zdaniem, z przekonania, że w ,epoce idealizmu niemieckiego jeszcze raz trzeba było podjąć próbę zbliżenia, a nawet tam gdzie to było możliwe, utożsamienia nauki o pięknie, która stała się nauką refleksyjną, z Objawieniem chrześcijańskim"20. Balthasar jest przekonany, że to właśnie pewien rodzaj estetyzmu religijnego nieustannie ożywiał idealizm niemiecki i to dzięki niemu niósł on ze sobą dynamiczność myślenia o świecie. Rzeczywistości estetyczna i religijna także wpisują się oczywiście w klimat romantyzmu niemieckiego. Samo zaś doświadczenie estetyczno-religijne ujawnia podstawowy problem filozoficzny idealizmu niemieckiego: przeczucie tego, co nieskończone. Takie nastawienie odpowiada zamiarowi ukazania zależności pomiędzy człowiekiem (podmiotem skończonym) a Absolutem (podmiotem nieskończonym) ${ }^{21}$. W ten sposób doświadczenie, mające swe źródło w namyśle estetycznym, jest w stanie odkryć to, co zdaje się podstawowe dla myślenia estetycznego, a mianowicie religijność. Jeśli podmiot chce dotrzeć do tego, co nieskończone, a nie do własnego wnętrza, droga prowadząca od doświadczenia estetycznego zmierza do pierwotnego źródła, ukrytego w tym, co boskie.

Rozważania dotyczące idealizmu niemieckiego mogą stanowić wprowadzenie w metodę i strukturę całościowego myślenia Balthasara, obejmującego zarówno jego twórczość filozoficzną,

\section{${ }^{20}$ CH I, s. 67.}

${ }^{21}$ Balthasar powołuje się w tym miejscu na doświadczenie sztuki, obecne u myślicieli idealizmu niemieckiego. Odwołując się do Aloisa Güglera, stwierdza, że „prawdziwa świadomość zamknięta jest w boskiej świadomości, a sztuka rodzi i rozwija ją w rzeczywisty sposób, budząc uśpione duchy w ludzkiej duszy, dlatego jej dzieła zaliczają się do kreacji boskości”; CH I, s. 83. 
jak i teologiczną. Mogą również wprowadzać w rozumienie zasadniczych linii rozwoju jego dzieła, postrzeganego całościowo $\mathrm{w}$ aspekcie teologicznego a priori, przenikającego i umacniającego całe jego myślenie literacko-filozoficzne ${ }^{22}$. Dla Balthasara „niemiecki idealizm znosi przymierze między chrześcijaństwem a starożytnością. Rozumuje on z punktu widzenia absolutnej samoobecności Ja (Fichte), momentu absolutności ludzkiej wolności (Schelling), możliwości pomyślenia wszystkiego, co rzeczywiste, przez ducha (Hegel), przez co idea, że to, co absolutne w ludzkim duchu, musi istnieć dzięki innemu Bogu, staje się wątpliwa"23.

W jednym z pierwszych swych dzieł, Apokalypse der deutschen Seele, Balthasar ukazuje idealizm niemiecki w perspektywie religijnej. Zostaje ona jednak skonfrontowana z perspektywą myślenia nowożytnego, które wraz z Kantem metafizykę eschatologiczną zamienia w eschatologię transcendentalną. Pragnie ona w centrum umieścić człowieka, podlegającego czasowości, a przez to stawaniu się. W związku z tym dochodzi jakby do przesunięcia rozważań eschatologicznych z Absolutu na byt skończony, jakim jest człowiek w świecie.

Prawdziwa filozofia chrześcijańska miała żyć namiętnością boskiego Logosu i w ten sposób przywracać zsekularyzowanym treściom teologicznym ich prawdziwą postać ${ }^{24}$. Stosunek idealizmu niemieckiego do chrześcijaństwa ukazuje, według Balthasara, problem, na ile nowożytna i współczesna filozofia religii, przedstawiając siebie jako niezależną od chrześcijaństwa, w gruncie rzeczy „żywi się albo przejęciem, albo negacją chrześcijańskich idei dotyczących porządku naturalnego"25. Idealizm

22 Por. A.M. Haas, Zum Geleit, dz. cyt., s. XXV-XLVIII.

${ }^{23}$ H.U. von Balthasar, Prawda jest symfoniczna. Aspekty chrześcijańskiego pluralizmu, tłum. I. Bokwa, Poznań 1998, s. 141.

${ }^{24}$ Por. OZFK, s. 20-21.

25 Tamże, s. 40. 
stanowił dla Balthasara dobre pole dla zilustrowania dyskusji pomiędzy chrześcijaństwem a myślą zsekularyzowaną. Trudno byłoby sobie wyobrazić wielkich idealistycznych filozofów bez myśli chrześcijańskiej ${ }^{26}$. Zdaniem Balthasara, wszyscy oni, „nawet ci, którzy otwarcie odżegnują się od wiary w Chrystusa, jak Hebbel, Wagner czy Nietzsche, nie mogą się uwolnić od postaci Syna Człowieczego i próbują to, co po Nim pozostaje, przenosić w nowe poznanie i nowe formy życia" 27.

Według Balthasara, sekularyzacja dotykała wyraźnie wszystkich sfer życia kulturalnego i była łatwa do przeanalizowania zarówno pod względem ogólnego, wzajemnego stosunku filozofii i teologii, ich punktów stycznych, jak też w nawiązaniu do tendencji zanikania wspólnych korzeni chrześcijaństwa. „Proces sekularyzacji przebiega na naszych oczach $\mathrm{z}$ taką anatomiczną dokładnością, że daje się prześledzić w najdrobniejszych szczegółach. Kim jest Kant bez Lutra i jak zrozumieć jego etykę bez warunków stworzonych przez protestantyzm? Kim jest Herder bez Biblii i Ojców Kościoła, Novalis bez Böhmego i Zinzendorfa, kim są Hölderlin i Hegel bez głębokiego przesiąknięcia pismami Janowymi?"28.

Religijność rozumiana jako przeczucie tego, co nieskończone, może zmierzać w dwóch kierunkach. Jeśli osadzona będzie pierwotnie w tym, co nieskończone, zachowa swój właściwy charakter. Jeśli jednak przeczucie tego, co nieskończone, zmierzać będzie w kierunku tego, co skończone, jako źródła, wtedy estetyka może stać się estetyką nie religijną, a jedynie antropologiczną, a zrozumienia, czym jest piękno, trzeba będzie szukać wyłącznie w człowieku. Autentyczny zmysł religijny poszukuje zawsze tego, co nieuwarunkowane w boskim elemencie. Zmysł ten może przyjąć formę analogiczną do kantowskiego imperatywu, któ-

\footnotetext{
${ }^{26}$ Por. tamże, s. 40-41.

27 Tamże, s. 41.

28 Tamże, s. 41-42.
} 
ry nakazuje szukanie ostatecznej miary - ale nie w podmiocie, a w chwale innego. Dlatego też dla Balthasara chwała jako piękno Boga jest podstawową miarą właściwej religijności. Tę widzi on przede wszystkim w wielkiej neoplatońskiej tradycji Plotyna czy Kuzańczyka. Pewne zbliżenie się systemu idealistycznego do Plotyna nie oznacza jeszcze zdecydowanej postawy otwartego oczekiwania, która była u niego wiodąca. Ostateczne rozstrzygnięcia idealistyczne dokonują się w czystej filozofii, w obszarze tego, co leży w granicach możliwości człowieka, historii i kultury. Jeśli „u Plotyna nie zapada ostateczna decyzja (a w każdym razie nie jest ona wyrazista) opowiedzenia się za »żywym Bogiem « Biblii”, to „Fichte tę formę żywotności namiętnie odrzuca”29.

Jeśli idealizm niemiecki źródło namysłu religijnego widzi w tradycji neoplatońskiej, Balthasar ocenia go jak najbardziej pozytywnie. Ale gdy ten sam idealizm w celu zrozumienia tego, co nieuwarunkowane, zwraca się ku filozofii transcendentalnej, to znaczy takiej, która próbuje zamknąć się w granicach bytu skończonego, a zatem w doświadczeniu piękna o charakterze antropologicznym, Balthasar, jeśli go nie odrzuca, to przynajmniej się od niego dystansuje.

Wydaje się, że Balthasar wyraża swe zastrzeżenia zawsze co do tego, że człowiek chce dojść do rozumienia piękna jedynie o własnych siłach. W filozofii transcendentalnej podmiot za wszelką cenę dąży do sytuacji, w której będzie zdolny sam z siebie wznieść się na płaszczyznę Absolutu. W takim rozumieniu człowiek jest niczym innym, jak tylko potencjalnością, ale potencjalnością, która tworzy własną drogę zjednoczenia się z tym, co absolutne. Owszem, ta droga przyjmuje formę prawie mistyczną ${ }^{30}$. W ten

${ }^{29} \mathrm{CH}$ III/1/2, s. 498.

${ }^{30}$ Balthasar stwierdzi: „Z tej podstawowej struktury, którą w takiej formie po raz pierwszy buduje Fichte, rozwija się niczym z jednego korzenia cały idealizm niemiecki”; AP I, s. 176. 
sposób człowiek ma nieograniczoną moc, która wypływa przede wszystkim z jego wolności. Przezwyciężanie wolności pozwala mu nawiązać kontakt z tym, co absolutne.

Religijny neoplatonizm ukazywał doświadczenie mistyczne jako pewną zdolność do wolności i dzielenia się nią, ponieważ wynikała ona nie z niego samego, ale z wolnego obdarowania przez Boga. W rozumieniu filozofii transcendentalnej człowiek ma wolność jakby sam z siebie, a w mocy tej wolności jawi mu się perspektywa otwarcia na rzeczywistość Absolutu. Relacja do Absolutu stanowi jednak tylko zbiór możliwości jego wewnętrznych przezwyciężeń i działań. Wtedy Absolut pojawia się jakby na horyzoncie, a to, co najważniejsze, to ludzka wolność, która $\mathrm{w}$ takiej perspektywie może mieć także charakter transcendentalny. Neoplatonizm wskazywał, że człowiekowi, poniekąd z mocy samego Absolutu, dane jest uczestnictwo w tym, co boskie. Transcendentalny podmiot stanowi zaś jedynie przestrzeń, w której ukazuje się i realizuje to, co absolutnie piękne. W ten sposób to człowiek, w swoim stawaniu się i w swojej wolności, okazuje się źródłem tego, co wzniosłe i piękne w świecie. Jeśli w całym myśleniu neoplatońskim element boski jest tym, który jest piękny, który udziela swego piękna wszystkiemu, co istnieje, to transcendentalna myśl proponuje, by postrzegać wszystko, co na ludzki sposób piękne, jako zarazem boskie.

Zderzenie myśli neoplatońskiej i transcendentalnej Balthasar postrzega jako charakterystyczny rys idealizmu niemieckiego. Przejawiać się on będzie jednak przede wszystkim w zmierzaniu do pewnego rodzaju antropocentryzmu, który widzi człowieka zanurzonego głównie w świecie. To dryfowanie w kierunku antropocentryzmu Balthasar ukazuje poprzez dwie postacie mitologiczne: Prometeusza i Dionizosa ${ }^{31}$. Prometeusz jest symbolem

${ }^{31}$ Por. tamże, s. 139-157. 
wzniosłej podmiotowości, która afirmując przede wszystkim siebie, wznosi się na poziom bogów. Skradziony z nieba ogień ma służyć rozwojowi człowieka. Posiadanie ognia to posiadanie mocy przemiany, to niszczenie w sobie tego, co słabe, i wznoszenie się do tego, co niezniszczalne. Takie pragnienie jednak wydaje się nieskończone, a zatem niemożliwe do zrealizowania. Dlatego też działanie Prometeusza jest ostatecznie nietrwałe, zajmuje tylko chwilę, a człowiek popada ponownie w nieuchronną słabość i pustkę.

Z drugiej strony pojawia się obraz Dionizosa, będącego postacią tragiczną. Dionizos bowiem to ten, który kocha przede wszystkim ziemię i ciało, a tylko w porywach zdolny jest unieść się ku temu, co nieskończone. Ziemskiemu pięknu towarzyszy udręka i melancholia samotności. Ostatecznie, nie osiągając nigdy sfer pozaziemskich, boskich, człowiek pozostaje postacią rozdartą i tragiczną. Kantowski człowiek ma zarówno odważną dumę Prometeusza, który wyrywa się ku spełnieniu swojego powołania, jak i znak rozdarcia Dionizosa. W takim napięciu dąży do stanu pewnej integralności eschatologicznej, której jednak nie znajduje i której nigdy nie urzeczywistni. Tym dwóm mitologicznym postaciom Balthasar przeciwstawi trzecią - Chrystusa, który w tajemniczy sposób wyrazi owo pragnienie zjednoczenia tego, co skończone i nieskończone. Będzie On promieniować światłem boskiego piękna w świecie.

Ostateczną ontologiczną formą całego świata jest dla Balthasara nadprzyrodzoność. Wydaje się zatem konieczne, by myślenie i działanie człowieka, całe jego życie i filozofowanie „było na zawsze już włączone w tę najwyższą formę bytu" ${ }^{32}$. Myśliciel chrześcijański stoi niejako „przed »przesłoniętym obrazem « świata nie jak poszukujący mądrości młodzieniec z ballady Schillera, lecz ra-

\footnotetext{
${ }^{32}$ H.U. von Balthasar, Apokalipsa niemieckiej duszy, w: PW 1, s. 146.
} 
czej jak (w uroczej interpretacji Novalisa) Hiacynt, któremu przy unoszeniu zasłony rzuca się w ramiona od dawna poszukiwana ukochana" 33 . Pytanie o relację między refleksyjnym myśleniem a intuicją religijną pozostaje wyzwaniem nadal aktualnym dla współczesnego człowieka, szukającego właściwego zrozumienia religii, która ciągle stawia wymagania i stara się formować ludzkie myślenie.

Niniejsza praca składa się z czterech rozdziałów. Pierwszy ukazuje przede wszystkim źródła i kontekst filozoficznej twórczości Hansa Ursa von Balthasara. Jego myśl filozoficzna rodzi się z egzystencjalnego doświadczenia człowieka żyjącego w świecie oraz z głębokiego przekonania o konieczności rozważania jej w kontekście myśli religijnej. Wprawdzie dla wielu Balthasar był w pierwszym rzędzie teologiem, nawet jeśli nigdy nie uzyskał tytułu doktora w tej dziedzinie, ale jego dzieła niosą ze sobą głęboką myśl filozoficzną. Jego przekonanie o tym, że prawdziwym teologiem może być tylko ten, kto jest zarazem filozofem, doprowadziło do zatarcia się granic między literaturą, filozofią i teologią. Swoje studia filozoficzne łączy Balthasar ze studiowaniem germanistyki najpierw w Zurychu, potem w Wiedniu, oraz ze studiami teologicznymi w Lyonie. Wynikające ze studiowania teologii (przede wszystkim ojców Kościoła) rozumienie filozofii jako całości stanowi moment otwarcia się na filozofię chrześcijańską i podjęcia próby przezwyciężenia idealizmu niemieckiego, prowadzi do pojmowania filozofii chrześcijańskiej jako filozofowania $\mathrm{w}$ wierze i ze względu na teologię.

W rozdziale pierwszym pracy podjęta zostanie także próba określenia metody filozoficznego myślenia Balthasara. W zasadzie trudno jednoznacznie ją sprecyzować, a jeszcze trudniej wskazać

33 Tamże, s. 146-147. 
taką, która obejmowałaby całą jego twórczość. Wydaje się jednak, że można ją rozumieć w dużej mierze jako fenomenologiczne ujęcie różnorodności form myślenia, wyraźnie odnoszące się do kategorii mitu i pojęcia formy, przechodzące od oglądu całościowego do pojęcia analogii. Filozoficzna myśl Balthasara tkwi mocno w tradycji filozofii neoplatońskiej, w której widzi on zespolenie wszystkich wartości mitu i religii. Postrzega ją jako powrót do źródeł, gdzie wszystko, co istnieje, nadal jest wzajemnie powiązane. W kontekście filozofii neoplatońskiej zostaną ukazane źródła zainteresowania się Balthasara filozofią idealizmu niemieckiego.

Rozdział drugi pracy zawiera opis relacji myślenia idealistycznego i refleksji chrześcijańskiej w literaturze niemieckiej dokonany przez Balthasara przede wszystkim w dziele Apokalypse der deutschen Seele. Literatura ta od samego początku przyjmuje jego zdaniem charakter religijnego a priori z wyraźnym rysem eschatologicznym. Przez pryzmat filozoficzno-historyczny patrzy Balthasar na rozwój niemieckiej filozofii ducha i przedstawia z chrześcijańskiej perspektywy ponad 700 lat z niemieckiego życia duchowego. Podjęte dzieło jest konfrontacją chrześcijańskiego punktu widzenia z całością historii immanentnego widzenia rzeczywistości, próbą ukazania dążenia do rozumienia świata w aspekcie jego transcendentnego pochodzenia. Perspektywa ta przybiera wyraźny rys eschatologiczny, apokaliptyczny. Według Balthasara, ,apokalipsa” oznacza przede wszystkim „odsłanianie” tego, co ukryte, dlatego też swoje zadanie widzi on w zrozumieniu postawy eschatologicznej danej epoki. „Apokalipsa duszy” oznacza odsłanianie jej ewentualnej umiejętności bycia całością, a więc „eschatologię” jako naukę o stosunku duszy do jej wiecznego przeznaczenia. Ponieważ filozoficzna próba systematycznego ujmowania historii zyskuje charakter mityczny, w tym rozdziale zostanie także przedstawiona Balthasarowska koncepcja mitu, wprowadzająca w po- 
czątki jego rozumienia dialektyki idealizmu niemieckiego. W dialektyce idealistycznej aktywność ludzkiego podmiotu zmierza do ujęcia w sobie całej rzeczywistości, aż po rozumienie świata jako produktu tejże aktywności. Balthasar odrzuca dążenia, które chciałyby widzieć świat jedynie przez pryzmat własnej aktywności podmiotu, i szuka możliwości wprowadzenia rozumu na drogi wiodące ku temu, co transcendentne, by na nowo odnaleźć zagubione pragnienie jedności świata. Ponieważ myślenie idealistyczne wyrasta z określeń i spekulacji Kanta, Balthasar zgadza się z tezą, że to właśnie Kantowska koncepcja krytyki rozumu doprowadziła do powstania spekulatywnych systemów Fichtego, Schellinga i Hegla.

Problem rozumienia idealistycznych systemów tych trzech filozofów podejmuje trzeci rozdział niniejszej pracy, pokazujący także, w jakiej mierze wpłynęły one na myśl Balthasara i jak zostały przez niego odczytane. Ideał harmonii, ukazywany według naszego autora w świecie starochrześcijańskim, jest wyzwaniem dla idealizmu niemieckiego, który musi dokonać niejako kroku wstecz, by móc na nowo zbudować jedność świata ludzkiego ducha i natury, jedność zatraconą w biegu historii. Głównym momentem myślenia idealistycznego jest mit Prometeusza, stojącego między Bogiem a światem. Człowiek staje się twórczym centrum całej rzeczywistości. Otrzymuje zatem zadanie bycia pośrednikiem między Bogiem a światem, a w nim jedynym, absolutnym mediatorem procesu dialektycznego. Ostatecznie jednak nie może stać się Prometeuszem i nie jest w stanie rozwiązać dialektycznej sprzeczności, a sam idealizm, zdaniem Balthasara, wydobywa na zewnątrz negatywną stronę Prometeusza. W tym kontekście zostanie opisana wewnętrzna zasada idealistycznej myśli, określana jako „mistyczna potencjalność”, będąca pośrednią formą między boską, czystą aktualnością a potencjalnością stworzenia. Zasada 
ta ujawnia się w myśli Fichtego o wolności podmiotu i jego relacji do tego, co nieskończone, oraz w oglądzie intelektualnym świata i przyrody Schellinga. Kto ostatecznie ma stanąć w centrum ludzkiego świata? Człowiek czy Absolut? Balthasar zdaje sobie sprawę, że skończony byt w świecie, podążając za twórczym impulsem pochodzącym z wnętrza Absolutu, zmierza do przedstawienia obecności Boga w tymże świecie.

W tym rozdziale pracy została wprowadzona kategoria estetyki teologicznej i filozoficznej, rozwinięta w rozdziale następnym, ostatnim. Rozważania rozdziału trzeciego kończy Balthasarowska analiza myśli Heglowskiej, przedstawiona przede wszystkim w dialektycznym napięciu pomiędzy refleksją filozoficzną a myślą chrześcijańską. Z jednej strony dystansowanie się Balthasara od Hegla przyjmuje formę świadomego oddalania się od jego myślenia, z drugiej zaś ujawnia swoiste punkty styczne, ponieważ nawet pewne skrajności zdają się zbieżne. Napięcie pomiędzy filozoficznym systemem Hegla a chrześcijaństwem wpisuje się w dyskusję nad uprawomocnionym uprawianiem ,filozofii chrześcijańskiej”. Nie ulega wątpliwości, że Balthasar chce uprawiać filozofię w przestrzeni myślenia chrześcijańskiego. Celem mistycznej potencjalności jest według niego nie tyle zbliżenie się światów natury i ducha do Boga, ile przede wszystkim związek, jaki tworzy z Nim indywidualny człowiek; tymczasem idealizm heglowski poprzez refleksję przenosi jednostkę w świat konieczności, świat idei. Kluczem do zrozumienia relacji między światem ludzkim a boskim mogłaby być miłość, tej jednak Balthasar nie znajduje ani u Hegla, ani u innych myślicieli idealizmu.

Ostatni, czwarty rozdział pracy podejmuje próbę wykazania, że punktem wyjścia namysłu nad idealizmem jest zwrócenie uwagi na kategorię piękna. Balthasar wskazuje na fakt, że myśleniu idealistycznemu, nawet jeśli wchłonęło w siebie wszelką 
treść chrześcijańską, brakuje pewnego pierwiastka różnicującego. Są nim pojęcia chwały i piękna. Próba odpowiedzi na pytanie, w jaki sposób z ram filozoficznego szkicu wyłączyć specyfikę chwały chrześcijańskiej i do jakiego stopnia jest to możliwe, została podjęta $\mathrm{w}$ pochodzącym z późniejszego okresu twórczości Balthasara dziele Chwata. Estetyka teologiczna. Pytanie o chwałę stało się jednocześnie pytaniem o filozoficzne i teologiczne rozumienie piękna. Rozważania na temat piękna umieszcza Balthasar w ramach klasycznie pojętych transcendentaliów: prawdy, dobra i piękna. Stara się wykazać, że ta ostatnia kategoria pozwala dostrzec w świecie to, co boskie. Prawdziwa wartość bytu nie może być dostrzegalna i oddziaływać mocą, jeśli nie otworzymy się na przyjęcie i zrozumienie piękna odwiecznego, ukazującego się pod formami widzialnymi. W ten sposób piękno staje się podstawową kategorią filozoficzną, stosowaną także w myśleniu teologicznym. Kategoria ta, wspomagana pojęciem „postaci” zaczerpniętym z twórczości Goethego, miała uwrażliwić i wskazać na więź istniejącą między pięknem i religią, między światem ludzkim i boskim, między tym, co skończone, i tym, co nieskończone. W historycznym doświadczeniu chwały Balthasar jeszcze raz podda próbie idealizm niemiecki. Ani kantowskie wzniosłość i piękno, ani ideał sztuki Fichtego, ani mitologia Schellinga przenikania się tego, co nieskończone i skończone, nie wytrzymują tej próby, ponieważ prowadzą do Heglowskiej koncepcji zastąpienia teologii przez filozofię, wiary przez wiedzę. 
Refleksje i analizy przedstawione w niniejszej książce rodziły się przez wiele lat, podlegając różnym weryfikacjom i zmianom. Ostateczny kształt praca przybrała dzięki pomocy i współpracy wielu ludzi, których spotkałem na drodze moich poszukiwań naukowych.

Wśród osób, którym zawdzięczam pierwsze inspiracje związane z Hansem Ursem von Balthasarem, chciałbym wspomnieć panią Janinę Łuczak-Wild, z którą prowadziłem dyskusje nad idealizmem niemieckim w czasie mojego pobytu w Bazylei. Zachętę do podjęcia trudnego zagadnienia i cenne wskazówki merytoryczne związane ze struktura pracy otrzymałem od o. prof. Petera Henriciego, ówczesnego biskupa z Zurychu i promotora mojej pracy doktorskiej na Uniwersytecie Gregoriańskim w Rzymie. Wdzięcznie wspominam okres dyskusji nad tematyką mojej pracy w czasie stypendium naukowego na Uniwersytecie w Grazu, gdzie spotkałem się z wielką życzliwością prof. Reinholda Esterbauera i jego współpracowników. Ważne, szczególnie metodologicznie, były dla mnie uwagi profesorów Karla Josefa Wallnera, Michaela Schulza, Wernera Lösera i Emmanuela J. Bauera.

Z wieloletniej współpracy z prof. Aleksandrem Bobką w Katedrze Historii Filozofii Nowożytnej i Współczesnej Papieskiej Akademii Teologicznej, a później Uniwersytetu Papieskiego Jana Pawła II w Krakowie wyniosłem otwartość umysłu i szerokie spojrzenie na problemy natury filozoficznej, religijnej i społecznej, a w ostatnim czasie otrzymałem także wiele cennych sugestii i komentarzy oraz pomoc w pisaniu pracy. W tym miejscu chciałbym również podziękować wszystkim pracownikom Wydziału Filozoficznego za życzliwość i wsparcie, za wszelkie uwagi i chętnie podejmowane dyskusje. 
Szczególną wdzięczność chciałbym wyrazić pani Dorocie Jankowskiej za wieloletnie wspólne twórcze myślenie, za życzliwość i bezcenne wsparcie translatorskie i korektorskie. Bez jej cierpliwości i dokładności nie byłoby zapewne możliwe takie uporządkowanie myśli i tekstu.

Pragnę wreszcie podziękować mojej wspólnocie redemptorystowskiej z Krakowa za cierpliwe znoszenie moich rozmaitych słabości i niedostatków oraz wsparcie w różnych momentach życia naukowego i kapłańskiego.

$\mathrm{Na}$ koniec dziękuję wszystkim bliskim moim myślom i sercu, którzy przez ten czas wspierali mnie życzliwym słowem, radą i modlitwą, wierząc, że praca, której się podjąłem, ma sens i przyniesie dobre owoce. 


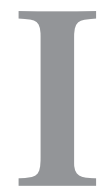

\section{Filozoficzna twórczość Balthasara}

Filozoficzna myśl Balthasara rodzi się z egzystencjalnego doświadczenia sytuacji człowieka w świecie i głębokiego przekonania o konieczności rozważania jej w kontekście myśli religijnej. Pod koniec swego życia Balthasar twierdził, że człowiek egzystuje ,jako ograniczona istota w ograniczonym świecie, ale jego rozum jest otwarty na to, co nieograniczone, na cały byt. Dowód na to leży w rozpoznawaniu jego nieskończoności, ograniczoności: jestem, ale też mogłoby mnie nie być. Wiele z tego, co istnieje, mogłoby nie istnieć. Istoty są ograniczone, ale byt nie. Ów rozpad, »rzeczywiste odróżnienie « św. Tomasza, jest źródłem wszelkiej myśli religijnej i filozoficznej”'. Balthasar jest przekonany, że filozofia przyjmuje charakter jednocześnie religijny, ponieważ „stawia pytanie o byt absolutny, czy jest on zrozumiały, czy też nie”2.

1 H.U. von Balthasar, Przemowa wygłoszona w Madrycie 10 maja 1988 roku z okazji otwarcia sympozjum poświęconego teologii Balthasara, w: E. Guerriero, Hans Urs von Balthasar. Monografia, tłum. M. Rodkiewicz, Wydawnictwo M, Kraków 2004, s. 402.

${ }^{2}$ Tamże, s. 402-403. 
Zrozumienia ludzkiej egzystencji szukał Balthasar także w kulturze, sztuce i muzyce, wierząc, że sam rozum nie może stanowić pełnej odpowiedzi człowieka na rzeczywistość i nie potrafi oddać tego wszystkiego, co człowiek może, chce i musi wyrażać. Snując refleksje dotyczące sztuki, religii i muzyki, Balthasar dostrzegał intuicyjnie myśl, która wyrastała z metafizycznej powinności. Jak sam pisał: „Ponieważ sztuka jest czymś zmysłowym, a w istocie tego, co zmysłowe, leży poruszanie się ku ostatecznemu celowi, musimy założyć, że w sztuce istnieje celowy rozwój; nie rozwój na »chybił trafił «, lecz rozwijanie się czasowo-przestrzenne i dążenie do osiągnięcia maksimum (...). Jest nim możliwie jak największa obiektywacja tego, co metafizyczne, co Boskie"3. To właśnie poprzez sztukę element boski zostaje niejako wpisany w kategorie czasowo-przestrzenne, uzyskując formę zmysłowej bezpośredniości, która przyjmuje różne postaci.

Balthasar negował interdyscyplinarne granice pomiędzy literaturą, filozofią i teologią. Interesowało go przede wszystkim pogłębienie historii pojęcia tego, co stanowi rzeczywistość w aspekcie ostatecznym. To ona miała być miejscem zrozumienia kulturowych zmian, jakie dokonywały się w ciągu wieków. Sposób, w jaki filozofia i teologia usiłują wyjaśniać dzieła sztuki i na odwrót, użycie tych dzieł do zrozumienia historii myślenia, bez istotowego wejrzenia w ich jakość estetyczną, jest zdaniem Balthasara zaskakujący. Był on bowiem przekonany, że literaturoznawstwo przechodzi na wyższy poziom, w filozofię, a ta z kolei w sztukę. Obie dziedziny jednak (podobnie jak teologia) - w konkretną egzystencję historyczną ${ }^{4}$.

${ }^{3}$ H.U. von Balthasar, Rozwój idei muzycznej, w: PW 2, s. 27.

${ }^{4}$ Por. AP I, s. 10. „Przez to, że filozofia, teologia i sztuka otaczają eschaton i niejako w apokaliptycznej spirali przedzierają się od zewnątrz do środka, od codzienności do cudu, od rzeczy do ducha, są naukami humanistycznymi, to znaczy narzędziami samoodsłaniania się duszy"; tamże, s. 4. Por. także M. Bieler, Meta-antropologia e cristologia. A riguardo della filosofia 
Dla wielu Balthasar był w pierwszym rzędzie teologiem ${ }^{5}$. Jego dzieła niosą ze sobą jednak głęboką myśl filozoficzną. Sam Balthasar jest przekonany o tym, że „teologiem może być na serio tylko ten, kto zarazem i jeszcze uprzednio jest filozofem"6. Teologiczne myślenie zakłada bowiem w naturalny sposób teoriopoznawczy i ontologiczny charakter struktury wszelkiego bytu. Z drugiej strony, Balthasar wysuwa tezę, że każda filozofia zawiera teologiczne a priori ${ }^{7}$. Wydaje się, że kluczem do zrozumie-

di Hans Urs von Balthasar, „Communio. Rivista Internazionale di Teologia e Cultura” 1991, nr 117, s. 107-121.

${ }^{5}$ „Zawsze można spotkać się ze zdziwieniem, kiedy dokonuje się sprostowania, że Hans Urs von Balthasar nigdy nie był profesorem i nigdy też nie uzyskał tytułu doktora teologii. Jednak tytuł »Dr. phil.«, jaki przyznano germaniście, zawierał więcej niż tylko niewielką cząstkę filozofii. To właśnie filozofii, dla dobra teologii, Balthasar pozostał wierny do końca swego życia"; P. Henrici, O filozofii Hansa Ursa von Balthasara, w: PW 1, s. 153. Emmanuel J. Bauer napisze: „Nie będzie chyba zbyt śmiałym nazwanie Balthasara najlepiej wykształconym teologiem i najbardziej uniwersalnym myślicielem chrześcijańskim naszego stulecia, myślicielem, którego przeogromne i niewiarygodnie wszechstronne dzieło należy zaliczyć do największych i najtrwalszych osiągnięć współczesnej teologii i historii ducha. $\mathrm{Z}$ wielką literaturą europejską był tak samo dobrze obeznany jak z patrystyką czy historią zachodniej teologii i filozofii. Prowadził dialog z najważniejszymi prądami umysłowymi swoich czasów. (...) Jego pisma świadczą o nadzwyczajnej sile spekulatywnej, kontemplatywnej głębi myśli i szerokim horyzoncie teologicznym. Balthasar był bez wątpienia w pierwszym rzędzie teologiem, jego dzieła noszą jednak w istotnym stopniu piętno podejścia filozoficznego i można wśród nich znaleźć również traktaty prawdziwie filozoficzne"; E.J.Bauer, Hans Urs von Balthasar (1905-1988): Sein philosophisches Werk, w: Christliche Philosophie im katholischen Denken des 19. und 20. Jahrhunderts, Bd. 3: Moderne Strömungen im 20. Jahrhundert, hrsg. von E. Coreth, W.M. Neidl, G. Pfligersdorffer, Verlag Styria, Graz 1990, s. 285.

${ }^{6}$ TL I, s. 12. Por. na ten temat G. Giorgio, Il raporto di corrispondenza tra filosofia e teologia nel pensiero di Hans Urs von Balthasar, „Ricerche Teologiche" 10 (1991), nr 1, s. 271-296.

7 „Filozofia, która obchodzi się bez wszelkiej transcendencji, która się okopuje w sferze wewnątrzświatowej, wkrótce przestaje mówić o nie dających się rozwiązać »szyfrach « czy o »bycie, który należy paść«, i bardzo szyb- 
nia filozoficznego myślenia Balthasara jest określenie i uzasadnienie wzajemnego stosunku filozofii i teologii, pojawiające się już na samym początku jego twórczości. Jego zdaniem, można mówić o różnorodności przedmiotów formalnych teologii i filozofii. Ta druga rozważa bowiem przede wszystkim „byt tego świata, aby od niego dotrzeć do granic bytu absolutnego", teologia zaś „pierwotne samodawanie się Boga w Logosie, aby w objawienie Boga w Chrystusie i Kościele włączyć wreszcie także sens świata". Jednak obydwie nauki ogarnięte są jednością przedmiotu materialnego. Filozofia i teologia karmią się tym samym erosem. „Filozofia jako umiłowanie mądrości zawiera w sobie moment etyczny, a przez to moment decyzji, w którym widać wyraźnie zwrot człowieka ku totalnemu przedmiotowi, ku Absolutowi" .

Balthasar zdawał sobie sprawę, że otwarty rozum jest przede wszystkim rozumem filozoficznym, któremu podlegają zarówno

ko zadowala się formami i wariantami comte'owskiego pozytywizmu, którego ostatecznym efektem jest bezpłodność funkcjonalizmów, logicyzmów i analiz językowych, gdzie z prawdy jako ontycznego transcendentale nic już nie pozostaje"; TL I, s. 11.

${ }^{8}$ Por. OZFK, s. 5. W innym miejscu Balthasar napisze: „Integracja: program taki wymaga ścisłej współpracy między filozofią i teologią, która to współpraca staje się możliwa jedynie pod warunkiem, że obie te dyscypliny są wewnętrznie wzajemnie na siebie otwarte. To zaś jest możliwe tylko wtedy, gdy obie strony spróbują ponownie uczynić analogię między boskim praobrazem a ziemskim odbiciem centralnym przedmiotem swoich rozważań. Może przy tym chodzić nie tylko o podobieństwo człowieka do Boga i o pytanie, o ile ludzka postawa skierowana przeciwko Bogu sprawia, że zostaje ono lub nie zostaje utracone - lecz szerzej: o Boże podobieństwo bytu stworzonego w jego całości”; TL I, s. 18.

${ }^{9}$ Tamże, s. 6. „Nie ma więc wątpliwości, że filozof niechrześcijański żyje w swym myśleniu tą samą namiętnością do rzeczy ostatecznych, którą może żyć chrześcijański myśliciel jako wierzący, jako teolog. Każda prawdziwie żywa filozofia pozachrześcijańska żyje »teologicznym erosem «i tylko dzięki niemu ma moc poruszania i pociągania innych do przyjęcia podobnej poszukującej postawy także wobec rzeczy ostatecznych"; OZFK, s. 8. 
systemy filozoficzne, jak i wszystkie religie, o ile ich istotę można sprowadzić do religijnego rozumu człowieka jako istoty naturalnej i historycznej. Jeśliby umieścić Objawienie w ramach filozofii religijnej, to otwarty rozum ujmowałby jedynie dialog pomiędzy światopoglądami i religiami i pozostawał ostatecznie dialogiem ludzi o Bogu. Problem jednak pojawia się w momencie, kiedy chrześcijanin jasno i zasadniczo przekracza granice otwartego rozumu i „rości sobie pretensje do tego, iż usłyszał i interpretuje słowo Boga. Słowo to, które zgodnie z definicją jest słowem podmiotu absolutnie innego od każdego człowieka i które jako słowo podmiotu absolutnego, wyrażającego $\mathrm{w}$ nim samego siebie (...) będzie w każdym razie głosiło rzeczy, jakich człowiek sam z siebie nie wie, ani wiedzieć nie może; rzeczy w pierwszym rzędzie nie o człowieku, lecz o Bogu, rzeczy, które jednak stają się bliskie i dotyczą człowieka, ponieważ przybliża się do niego Bóg"10.

Balthasar był przekonany, że myśl chrześcijańska znajdzie swoje dopełnienie w odwołaniu się do chrystologicznego aspektu namysłu nad rzeczywistością, który to aspekt wprowadza nas na zupełnie inną płaszczyznę niż otwarty rozum ${ }^{11}$. Jeśli jednak chrześcijanin przyjmie perspektywę chrystologiczną, to pozostaje mu następująca alternatywa: „albo wobec innych ludzi ująć w nawias własną wiarę i być dla nich uprzejmym, miłym czło-

${ }^{10}$ H.U. von Balthasar, Chrześcijanin a otwarty rozum, w: PW 1, s. 58.

11 „Bez radykalnego zniesienia porządku stworzenia, słowo o JEDNYM BOGU nie może rozbrzmiewać równocześnie w miliardach pojedynczych podmiotów ludzkich. (...) Jako słowo o Jednym może ono logicznie rozbrzmiewać tylko w JEDNYM miejscu czasowo-przestrzennym, a mianowicie w »całkiem-innym-bycie « człowieka, który głosi, przedstawia i reprezentuje, w sposób dla wszystkich obowiązujący, »całkiem-inny-byt « Boga. Jest to fakt specyficznie chrześcijański i teologiczny, który zdecydowanie różni się od otwartego rozumu filozoficznego - kończy jego otwartość, wiąże ją w jednym punkcie i przez to wydaje się być dla rozumu absolutnym zgorszeniem"; tamże. 
wiekiem, albo nadać jej wielkie znaczenie i głosić ją w sposób apostolski. W pierwszym przypadku może mieć co najwyżej nadzieję, że swoim człowieczeństwem pośrednio propaguje własną wiarę, w drugim przypadku musi przyjąć na siebie ograniczenie »otwartego rozumu « i w sprawach ważnych zażądać od niego posłuszeństwa słowu Chrystusa" ${ }^{2}$.

Człowiek jako indywiduum podlega wszystkim prawom filozofującego rozumu i jego zadaniem jest bycie otwartym na pytania, które dotyczą jego samego oraz pozwalają zrozumieć go jako człowieka i chrześcijanina. Balthasar wierzył mocno, że bycia człowiekiem i chrześcijaninem nie trzeba wcale rozumieć jako opozycji otwartości i zamknięcia. Żywił głębokie przekonanie, że „bycie chrześcijaninem, jeśli prawidłowo je pojmuje i w całej pełni przeżywa, hartuje go do właściwego, godnego bycia człowiekiem i że wprowadza go ono na tę drogę"13. Dlatego też myśl filozoficzna wydaje się od samego początku obecna w twórczej działalności Balthasara. Jego książki, od pierwszej do ostatniej, przesiąknięte są filozofią. Bogactwo filozoficznej myśli stanie się w przyszłości nie tylko pomocniczym narzędziem rozumienia teologii, ale często będzie niezbędnym warunkiem jej uprawiania.

\section{Studium filozoficzne}

Studiowanie filozofii rozpoczyna Balthasar wraz ze studium germanistyki najpierw w Zurychu, a potem w Wiedniu. Okres ten naznaczony jest przyjaźnią z Rudolfem Allersem ${ }^{14}$. Staje

12 Tamże.

13 Tamże, s. 65.

14 Rudolf Allers (1883-1963) - wszechstronnie wykształcony, pochodzący z Wiednia lekarz, psychiatra i psychoterapeuta, ale również lingwista, filozof i teolog, tłumacz dzieł św. Tomasza i św. Anzelma. Jego wiedza nie tylko we wszystkich tych dziedzinach, ale również w zakresie literatury, hi- 
się ona dla Balthasara, jak sam napisze, „prawie niewyczerpanym źródłem inspiracji" "15, a słuchanie wykładów Hansa Eibla o Plotynie prowokuje i wskazuje drogi wiodące ku zainteresowaniu się teologią ${ }^{16}$. W Berlinie, na wykładach Romana Guardiniego, Balthasar styka się z myślą Sørena Kierkegaarda, która okaże się źródłem wielu inspiracji egzystencjalnych. Po wstąpieniu do Towarzystwa Jezusowego w 1929 roku odbywa dwuletni kurs filozofii w Pullach, a następnie czteroletnie studia teologiczne w Lyonie (Fourvière). Prowadzone w duchu scholastycznym filozoficzne wykłady w Pullach to jednocześnie czas spotkań z Erichem Przywarą, któremu Balthasar wiele zawdzięczał zarówno w latach swego kształcenia teologicznego, jak i później. To o nim pisał: „Spora ilość głównych tematów wywodzi się z jego wskazówek"17.

storii i muzyki była niezwykła. Biegle władał siedmioma językami obcymi. Wykładał m.in. na uniwersytetach w Austrii, Szwajcarii, Francji i Stanach Zjednoczonych, gdzie żył i pracował od 1938 roku.

${ }^{15}$ H.U. von Balthasar, Retrospektywa, w: OMD, s. 63. Balthasar mówi o Allersie: „Przeciwnik Freuda, będąc wolnym kontynuatorem myśli Alfreda Adlera, zwracał uwagę na miłość bliźniego jako obiektywne medium ludzkiej egzystencji; w zwrocie od »ja « ku rzeczywistości przepełnionej »ty «tkwiła dla niego prawda filozoficzna i metoda psychoterapeutyczna"; tamże, s. 64. Balthasara łączyła z Allersem również miłość do muzyki. Z nim to często wieczorami grywał na cztery ręce symfonie Mahlera w transkrypcji na fortepian; por. H.U. von Balthasar, Unser Auftrag: Bericht und Entwurf, Johannes Verlag, Einsiedeln 1984, s. 37-38.

${ }^{16}$ „Być może wiedeńskie wykłady Hansa Eibla o Plotynie, które mnie fascynowały, były w czasie moich studiów germanistycznych okrężną drogą, którą doszedłem do zainteresowania się teologią"; tamże, s. 31.

${ }^{17}$ H.U. von Balthasar, Krótki przewodnik po moich ksiażkach, w: OMD, s. 16-17. „Kościół musi prowadzić rozmowę z myślą czasów współczesnych, wszystkich czasów. Ojcowie Kościoła i szczytowi scholastycy pozostają tego najlepszym przykładem; mistrzami naszych czasów byli w tym względzie Erich Przywara i Joseph Maréchal z ich sztuką rozumiejącej interpretacji i transpozycji”; tamże, s. 30. Urodzonego w 1889 roku w Katowicach Ericha Przywarę Balthasar określał jako tego, któremu „w latach mojego kształcenia teologicznego i jeszcze długo potem 
Podczas studium teologicznego czyta Balthasar pod katem filozoficznym wielkie dzieła ojców Kościoła ${ }^{18}$. Aspekty filozoficzne dostrzega przede wszystkim w pracach Orygenesa ${ }^{19}$, Grzegorza z Nyssy ${ }^{20}$ i Maksyma Wyznawcy ${ }^{21}$. Refleksje na temat początków filozofii egzystencjalnej, filozofii stawania się, rozumienia filozofii jako całości będą stanowiły początek otwarcia się na filozofię chrześcijańską oraz dążenia do przezwyciężenia idealizmu nie-

byłem zobowiązany tak bardzo, że spora ilość głównych tematów wywodzi się z jego wskazówek"; tamże, s. 16-17. W innym zaś miejscu dodał, że Przywara był „niezapomnianym drogowskazem; takiego połączenia głębi i pełni, porządkującej jasności i obejmującej wszystko rozpiętości nigdy potem już nie spotkałem"; H.U. von Balthasar, Retrospektywa, dz. cyt., s. 64 .

18 „Dopiero znacznie później, kiedy od wielu lat miałem za sobą nagły błysk światła powołania i kiedy ukończyłem już studia filozoficzne w Pullach (z daleka »nadzorowane « przez Ericha Przywarę) oraz cztery lata teologii w Lyonie (zainspirowany przez Henriego de Lubaca) wraz z moimi współuczniami Daniélou, Varillonem, Bouillardem i wieloma innymi, dopiero wtedy zrozumiałem, jak wielką pomocą w stworzeniu koncepcji mojej teologii miała być znajomość Goethego, Hölderlina, Nietzschego, Hofmannsthala, a szczególnie ojców Kościoła, na których zwrócił mi uwagę de Lubac"; H.U. von Balthasar, Unser Auftrag, dz. cyt., s. 32.

19 Orygenesowi poświęcił Balthasar obszerny artykuł Le Mystérion d’Origène (w „Recherches de Science Religieuse” 26 (1936), s. 513-562; 27 (1937), s. 38-64), który w roku 1957 ukazał się w formie książkowej jako Parole et Mystère chez Origène. Balthasar jest również autorem przekładu tekstów Orygenesa na język niemiecki, które w 1938 roku wybrał i wydał pod tytułem Origenes. Geist und Feuer. Ein Aufbau aus seinen Werken, Otto Müller, Salzburg 1938.

20 Tom z roku 1942 poświęcony Grzegorzowi Présence et Pensée nosi podtytuł Essai sur la philosophie religieuse de Grégoire de Nysse i omawia szczegółowo różnice pomiędzy rozmaitymi formami bycia w ramach filozofii stawania się. Por. P. Henrici, O filozofii Hansa Ursa von Balthasara, dz. cyt., s. 154 .

${ }^{21}$ Książka o Maksymie ukazała się w roku 1941 we Fryburgu pod tytułem Kosmische Liturgie. Höhe und Krise des griechischen Weltbilds bei Maximus Confessor. 
mieckiego i niektórych intuicji Heideggera ${ }^{22}$. Obok studiów i prac na temat ojców Kościoła powstaje pierwsze filozoficzne dzieło Balthasara, będące próbą zanurzenia całej epoki niemieckiej filozofii ducha w historię chrześcijańską. Geschichte des eschatologischen Problems in der modernen deutschen Literatur ${ }^{23}$ to owoc jego filologiczno-filozoficznych studiów w Zurychu. Ostatecznego opracowania tego samego materiału Balthasar dokona kilka lat później w trzech tomach Apokalypse der deutschen Seele ${ }^{24}$, która przyniesie przede wszystkim poszerzenie i pogłębienie filozoficznego tła dysertacji. W przeważającej mierze filozoficzny pierwszy tom Der deutsche Idealismus ${ }^{25}$ zawiera monografie na temat Herdera, Kanta, Fichtego, Schellinga, Hegla i kończy się przejętym z pracy doktorskiej rozdziałem „Kierkegaard i Nietzsche”, podczas gdy $\mathrm{w}$ tomie drugim, Im Zeichen Nietzsches, zostają przedstawieni Bergson, Klages i ponownie Nietzsche, a ostatni tom, Im Zeichen des Todes, zajmuje się Schelerem, Heideggerem i Karlem Barthem.

22 Por. H.U. von Balthasar, Krótki przewodnik po moich książkach, dz. cyt., s. 21.

${ }_{23}$ Tenże, Geschichte des eschatologischen Problems in der modernen deutschen Literatur, Abhandlung zur Erlangung der Doktorwürde der philosophischen Fakultät I der Universität Zürich, Selbstverlag des Verfassers, Zürich 1930 (wydanie poprawione i uzupełnione: Geschichte des eschatologischen Problems in der modernen deutschen Literatur, Johannes Verlag Einsiedeln, Freiburg $1998^{2}$ ).

24 Tenże, Apokalypse der deutschen Seele. Studie zu einer Lehre von letzten Haltungen, Salzburg 1937-1939 (wydanie poprawione i uzupełnione: Apokalypse der deutschen Seele. Studien zu einer Lehre von letzten Haltungen, Bd. I: Der deutsche Idealismus (1937), Bd. II: Im Zeichen Nietzsches (1939), Bd. III: Vergöttlichung des Todes (1939), Studienausgabe der frühen Schriften unter der Leitung von A.M. Haas, Johannes Verlag Einsiedeln, Freiburg 1998).

${ }^{25}$ W roku 1947 tom ten ukazał się w niezmienionej formie, jedynie z nowym słowem wstępnym, pod tytułem Prometheus. Studien zur Geschichte des deutschen Idealismus (wydawnictwo F. H. Kerle, Heidelberg). 
$42 \quad+\quad$ Hans Urs von Balthasar wobec idealizmu niemieckiego

Kolejne prace pochodzące $\mathrm{z}$ pierwszego okresu twórczości Balthasara tworzą w jego pismach filozoficznych pewnego rodzaju rozdroże. Pierwszą z nich jest długa rozprawa z roku 1946 O zadaniach filozofii katolickiej $w$ czasach wspótczesnych ${ }^{26}$. Balthasar pojmuje filozofię chrześcijańską jako filozofowanie w wierze i ze względu na teologię ${ }^{27}$. Rozprawa ta jest wprowadzeniem w rozumienie Balthasarowskiej metody uprawiania filozofii, a jednocześnie może uchodzić za odpowiedź na zarzut wrogości wobec scholastyki, którą mu przypisywano ${ }^{28}$. Szczególnym osiągnięciem filozofii chrześcijańskiej były według Balthasara sztuka „o t wi erania (Aufsprengung) każdej skończonej prawdy filozoficznej na Chrystusa” oraz sztuka „wyjaśniającej transpozycji (klärende Transposition)"29. Balthasar szkicuje zadania i możliwości spotkania z filozofią życia, filozofią egzystencjalną i „nowożytnym duchem historii" ${ }^{30}$. Warunki wstępne dla obopólnie

${ }^{26}$ H.U. von Balthasar, Von den Aufgaben der katholischen Philosophie in der Zeit, „Annalen der Philosophischen Gesellschaft der Innerschweiz” 3 (1946/47), nr 2/3, s. 1-38 (wyd. pol.: O zadaniach filozofii katolickiej w czasach współczesnych, tłum. M. Urban, WAM, Kraków 2003).

${ }^{27}$ „O dzisiejszym położeniu filozofii katolickiej można więc dyskutować owocnie tylko wtedy, jeśli najpierw poruszy się to, co w problemie istotne; i właśnie od tej zasadniczej kwestii zaczynają się poniższe rozważania. Myśl katolicka, znajdująca się dziś w trudnym położeniu, zostanie właściwie ukierunkowana tylko $\mathrm{w}$ świetle rozwiązania podjętego »z najwyższego poziomu «. Jeśli nie wzniesie się na ten poziom, będzie nerwowo i niespokojnie wahać się pomiędzy modernizmem (Modernität) zredukowanym do filozofii współczesnego świata, pociągniętym i zafascynowanym jej urokiem, który pod pozorem dotrzymywania kroku czasom oddaje się i zatraca w każdym rozkwitającym właśnie prądzie i kierunku, a dumną samowystarczalnością, która opierając się na mającej kiedyś znaczenie średniowiecznej syntezie chrześcijaństwa i świata, zdaje się omijać każdy wewnętrzny spór z filozofią nowożytną"; OZFK, s. 13.

28 Por. P. Henrici, O filozofii Hansa Ursa von Balthasara, dz. cyt., s. 155.

${ }^{29}$ OZFK, s. 24.

30 Tamże, s. 73. 
owocnego spotkania dostrzega przy tym w scholastycznej nauce o transcendentaliach i w różnicy realnej pomiędzy istnieniem (Sein) a istotą (Wesen). W 1947 roku publikuje filozoficzne rozważania na temat prawdy pod tytułem Wahrheit, tom I: Wahrheit der Welt ${ }^{31}$. Dzieło to miało ukazać, że prawdziwe poszukiwanie prawdy nie zmierza do obrony nominalizmu czy egzystencjalizmu, ale pragnie ułatwić filozoficzne podejście do specyficznie chrześcijańskiego rozumienia prawdy ${ }^{32}$.

Próbą syntezy ontologii i chrystologii jest przejście Balthasara od filozoficznego ujęcia prawdy do rozważań nad teologią Karla Bartha. Już wcześniej poświęcił mu obszerny rozdział w Apokalypse, a w roku 1951 książkę Karl Barth. Darstellung und Deutung seiner Theologie ${ }^{33}$. Zasadniczą treścią tego studium jest teoretyczne sformułowanie myśli chrystocentrycznej w kontekście analogii filozoficznej. Praca ponownie podejmuje i kontynuuje przerwany dialog między Przywarą i Barthem. Kończy się on niepowodzeniem z powodu ostrego przeciwieństwa pomiędzy analogia entis a analogia fide $i^{34}$.

31 H.U. von Balthasar, Wahrheit, Bd. 1: Wahrheit der Welt, Benziger, Einsiedeln-Zürich 1947. ,Jest to jedyne czysto systematycznie filozoficzne pismo Balthasara, tym razem bez szczegółowego omawiania wszystkich nazwisk, jednakże gruntownie przemyślane i w tle prowadzące jakby ciągły dialog przede wszystkim z Tomaszem z Akwinu i Heideggerem"; P. Henrici, O filozofii Hansa Ursa von Balthasara, dz. cyt., s. 156. Kolejne planowane tomy nie ukazały się, ale ten pierwszy został po latach w niezmienionej formie włączony do Balthasarowskiej Teologiki (Theologik, Bd. 1: Wahrheit der Welt, Johannes Verlag, Einsiedeln 1985; wyd. pol.: Teologika, t. I: Prawda świata, tłum. J. Zychowicz, WAM, Kraków 2004).

32 Por. H.U. von Balthasar, Krótki przewodnik po moich książkach, dz. cyt., s. $19-20$.

33 Tenże, Karl Barth. Darstellung und Deutung seiner Theologie, Hegner, Köln-Olten 1951.

34 „Trzeba więc było zapytać o podłoże trudności, zrozumieć sposób myślenia Bartha z jego pochodzeniem od idealizmu niemieckiego oraz skonfrontować go z katolickim sposobem myślenia, który łączy filozofię i teo- 
$44 \quad$ Hans Urs von Balthasar wobec idealizmu niemieckiego

W 1956 roku publikuje Balthasar dzieło Die Gottesfrage des heutigen Menschen ${ }^{35}$, w którym, odwołując się do różnych aspektów filozoficznych, próbuje wyjaśnić współczesnemu człowiekowi jego sytuację religijną. Artykuły o tematyce filozoficznej i metodologicznej pojawią się także w Mysterium Salutis ${ }^{36}$ oraz w pierwszych dwóch tomach Skizzen zur Theologie ${ }^{37}$. Dyskusje o filozoficznym charakterze na temat czasu i historii oraz teologii historii zawierają Theologie der Geschichte ${ }^{38}$ i Das Ganze im Fragment ${ }^{39}$.

Ostatni okres twórczości filozoficznej Balthasara obejmuje przede wszystkim teologiczną Trylogię, na którą składają się Estetyka, Teodramtyka i Teologika. Elementy filozoficzne przenikają w zasadzie całe to dzieło. W roku 1961 publikuje Balthasar pierwszy tom Estetyki. Zagadnienie umiejscowienia estetyki teologicznej w europejskiej historii ducha podejmuje w tomie III,1

logię, naturę i nadprzyrodzoność (zawsze z zachowaniem »względnej niezależności« tej pierwszej), co znajduje swe potwierdzenie przede wszystkim u Tomasza z Akwinu. Książka na temat Bartha, dzieło najbliższe teologii uniwersyteckiej, najwyraźniej pokazuje również, jak Balthasar konkretnie wyobrażał sobie wzajemne przenikanie się filozofii i teologii”; P. Henrici, O filozofii Hansa Ursa von Balthasara, dz. cyt., s. 156.

${ }^{35}$ H.U. von Balthasar, Die Gottesfrage des heutigen Menschen, Herold, Wien 1956.

${ }^{36}$ Por. Mysterium Salutis, II: Grundriß heilsgeschichtlicher Dogmatik, hrsg. von J. Feiner, M. Löhrer, Benziger, Einsiedeln-Köln 1967, s. 15-43, oraz Bewegung zu Gott, w: Spiritus Creator (Skizzen zur Theologie III), Johannes Verlag, Einsiedeln 1967, s. 13-50.

${ }^{37}$ H.U. von Balthasar, Verbum Caro (Skizzen zur Theologie I), Johannes Verlag, Einsiedeln 1960; Sponsa Verbi (Skizzen zur Theologie II), Johannes Verlag, Einsiedeln 1960.

${ }_{38}$ Tenże, Theologie der Geschichte, Johannes Verlag, Einsiedeln 1959 (wyd. pol.: Teologia dziejów. Zarys, tłum. J. Zychowicz, Kraków 1996).

39 Tenże, Das Ganze im Fragment. Aspekte der Geschichtstheologie, Benziger, Einsiedeln 1963. 
Herrlichkeit. Im Raum der Metaphysik ${ }^{40}$. Teodramatyka zawiera $\mathrm{w}$ tomie II, $1^{41}$ oraz III $^{42}$ elementy antropologii filozoficznej i filozofii historii. Ostania z części, Teologika, w pierwszym tomie zawiera wcześniejsze refleksje o prawdzie, a w następnych podejmuje filozoficzne rozważania na temat boskiej i ludzkiej logiki oraz różnicy bytowej ${ }^{43}$. Wreszcie Epilog ${ }^{44}$ jest ponownie filozoficzny w swym zasadniczym zrębie przez to, że z punktu widzenia filozofii zawiera klucz do całej Trylogii. Zwięzłe streszczenie myśli Balthasara, z filozofią jako centralną, prezentuje jego dzieło Wiarygodna jest tylko miłość $c^{45}$, w którym przedstawia przede wszystkim zarys filozofii miłości. Naukowo-teoretyczne stanowisko filozofii Balthasara w ostatnim okresie twórczości ukazuje jego wykład z roku 1982 Regagner une philosophie à partir de la théologie ${ }^{46}$.

40 Tenże, Herrlichkeit. Eine theologische Ästhetik, III,1: Im Raum der Metaphysik, Johannes Verlag, Einsiedeln 1965 (wyd. pol.: Chwała. Estetyka teologiczna III/1. Metafizyka, cz. 1: Starożytność, tłum. L. Łysień, WAM, Kraków 2011; Chwała. Estetyka teologiczna III/1. Metafizyka, cz. 2: Nowożytność, tłum. L. Łysień, WAM, Kraków 2013). „Po tym wielkim przedtakcie (w którym można widzieć jakby nowe, obszerniejsze opracowanie Apokalypse) kolejne pasaże filozoficzne prezentują się skromniej, mimo że mają do przekazania rzeczy ważne i nowe"; P. Henrici, O filozofii Hansa Ursa von Balthasara, dz. cyt., s. 158.

${ }^{41}$ H.U. von Balthasar, Theodramatik, II: Die Personen des Spiels, 1: Der Mensch in Gott, Einsiedeln 1976 (wyd. pol.: Teodramatyka, t. II: Osoby dramatu, cz. 1: Człowiek w Bogu, tłum. W. Szymona, Wydawnictwo M, Kraków 2006).

${ }^{42}$ Tenże, Theodramatik, III: Die Handlung, Johannes Verlag, Einsiedeln 1980.

${ }^{43}$ Tenże, Theologik, II: Wahrheit Gottes, Johannes Verlag, Einsiedeln 1985 (wyd. pol.: Teologika, II: Prawda Boga, tłum. J. Zychowicz, WAM, Kraków 2004).

${ }_{44}$ Tenże, Epilog, Johannes Verlag, Einsiedeln-Trier 1987 (wyd. pol.: Epilog, tłum. J. Zychowicz, WAM, Kraków 2010).

${ }^{45}$ Tenże, Glaubhaft ist nur Liebe, Johannes Verlag, Einsiedeln 1963 (wyd. pol.: Wiarygodna jest tylko miłość, tłum. E. Piotrowski, WAM, Kraków 2002).

${ }^{46}$ Tenże, Regagner une philosophie à partir de la théologie, w: Pour un philosophie chrétienne. Philosophie et théologie, Namur, Paris 1983, s. 175-187; 
$46 \quad$ Hans Urs von Balthasar wobec idealizmu niemieckiego

\section{Metoda filozoficzna}

Balthasar jest autorem trudnym do studiowania. Jest to trudność natury zarówno językowej i stylistycznej, jak i metodologicznej oraz merytorycznej. Można wyróżnić przynajmniej dwa istotne powody, które czynią lekturę jego tekstów wyjątkowo żmudną. Przede wszystkim trzeba wziąć pod uwagę obfitość publikacji z typową dla nich nieprzeciętną ilością przytaczanych źródeł tekstowych, rozsianych po całej historii filozoficznego myślenia: od filozofii zachodniej i wschodniej po mistykę, od ojców Kościoła po myśl średniowieczną i nowożytną, wreszcie świat literatury, muzyki, teatru i pisma z zakresu duchowości chrześcijańskiej. Trzeba często mieć głęboką znajomość wszystkich tekstów Balthasara, by nie zagubić się w widzeniu całości i rozróżnić, gdzie kończy się tekst źródłowy, a zaczyna oryginalny tekst Balthasara. Do tego trzeba dodać nader trudny sposób konstruowania przezeń wywodu. Neologizmy przeplatają się często z językiem teologicznym, pełnym wyrażeń z pogranicza poezji i modlitwy. W swym postępowaniu metodologicznym Balthasar zdaje się wychodzić od jasnych założeń typu apriorycznego, by następnie przejść do obrazów typu przedstawiającego, a potem znów powrócić do elementów a priori, by tworzyć logiczne konstrukcje i stwierdzenia o prostym, wyrazistym charakterze ${ }^{47}$.

treści filozoficzne zawiera także pośmiertny tomik Wenn ihr nicht werdet wie dieses Kind, Schwabenverlag, Ostfildern 1989.

${ }^{47}$ Por. R. Fisichella, Rileggendo Hans Urs von Balthasar, „Gregorianum” 71 (1990), nr 3, s. 511-546; por. także A. Scola, Hans Urs von Balthasar - ein theologischer Stil: eine Einführung in sein Werk, Dr. Bonifatius Buch Verlag, Paderborn 1996. 
W sposobie myślenia Balthasara trudno dostrzec systematyczność, chociaż nie ma raczej wątpliwości co do jej istnienia ${ }^{48}$. Jest on świadomy konieczności posiadania metody prowadzonych rozważań naukowych: „Oczywiście, że trzeba mówić i czysto, i jasno, i odpowiedzialnie, i zrozumiale. Reguły takiego myślenia i mówienia można jak najbardziej określić mianem naukowych. Według Husserla każda nauka swoją metodę wysnuwa z samej siebie"49. Sam Balthasar ceni sobie jednak brak systematyczności u Rahnera: „Powiedziałbym, że im mniej jest systematyczny [Rahner - przyp. M.U.], tym bardziej mi odpowiada. A jak przecież ostatnio często podkreśla, w ogóle nie chce być systematykiem" ${ }^{50}$. Niesystematyczność postępowania i fragmentaryczność niektórych wyrażeń w myśli Balthasara nie może być mylona z brakiem systematyczności natury teologicznej ${ }^{51}$.

\subsection{Myśl fenomenologiczna}

W filozoficznym myśleniu Balthasara trudno dostrzec jednoznaczną metodę naukową, jeszcze trudniej określić taką, która odnosiłaby się do całej jego twórczości. Dyskusja nad tym zagadnieniem jest więc dość złożona. Podejmowana była przez wielu naukowców, próbujących opisać szczególnie jego metodę teologiczną. Z jednej strony dyskusje te starają się ustalić sam przedmiot rozważań teologicznych Balthasara, z drugiej zaś związek metody z teologiczno-naukowym sposobem określenia tego przedmiotu. Określenie metody wiąże się często z przejściem od oglądu cało-

${ }^{48}$ Próba zrozumienia w świetle trzech transcendetaliów całościowego Objawienia jest już sama w sobie tworem systematycznym. Por. Duch i ogień.

Rozmowa Michaela Albusa z Hansem Ursem von Balthasarem, w: OMD, s. 89.

49 Tamże, s. 91.

50 Tamże, s. 93.

${ }^{51}$ Por. R. Fisichella, Rileggendo Hans Urs von Balthasar, dz. cyt., s. 513. 
ściowego do pojęcia analogii. Metoda teologiczna charakteryzuje się wówczas brakiem systematyczności, stanowi niejako rodzaj kontemplatywnego spojrzenia, starającego się przede wszystkim na drodze estetyczno-fenomenologicznej dotrzeć do tajemnic Bożych ${ }^{52}$. Podstawową i treściową kategorią myśli Balthasara staje się w wielu pracach estetyka jako duchowa możliwość oglądania tajemnic Bożych. W ten sposób jednak nieco zapomniany pozostaje element czasowy i historyczny wydarzeñ ${ }^{53}$. Werner Löser dostrzega wyraźny fenomenologiczny charakter metody Balthasara. Fenomenologia jednak, jeśli chce być nauką o obrazie Boga, zdeterminowana jest teologicznie. Absolutna postać Boga, Jezus Chrystus, jest bowiem pierwszą i ostatnią, najbardziej wewnętrzną, ontologiczną podstawą całego stworzenia. Stworzenie, mające w sobie element skończoności, pojawia się wobec nieskończoności Boskiej w pewnej analogicznej racjonalności, jak analogia entis. W ten sposób analogia jako relacja Boga i stworzenia ma swoją miarę w relacji Boga do stworzenia ${ }^{54}$. Podobnie metodę Balthasara określa James Naduvilekut, który dostrzega u niego niemożność neutralnej obserwacji objawiania się i stąd mówi o pewnego rodzaju uniesieniu związanym z doświadczaniem oblicza i blasku Boga ${ }^{55}$.

Fundamentalnym tematem metodologicznych rozważań pozostaje jednak zagadnienie analogii i fenomenologicznego cha-

${ }^{52}$ Por. J.R. Sachs, Spirit and Life. The Pneumatology and Christian Spirituality of Hans Urs von Balthasar, Hagelloch, Tübingen 1984.

53 Por. P. Eicher, Offenbarung. Prinzip neuzeitlicher Theologie, Kösel, München 1977; M. Hartmann, Ästhetik als ein Grundbegriff fundamentaler Theologie. Eine Untersuchung zu Hans Urs von Balthasar, EOS Verlag, St. Ottilien 1985.

${ }^{54}$ Por. W. Löser, Im Geiste des Origenes: Hans Urs von Balthasar als Interpret der Theologie der Kirchenväter, Josef Knecht, Frankfurt am Main 1976.

55 Por. J. Naduvilekut, Christus der Heilsweg: Soteria als Theodrama im Werk Hans Urs von Balthasars, EOS Verlag Erzabtei, St. Ottilien 1987. 
rakteru metody filozoficznej Baltahasra. Abstrakcyjna analogia entis przyjmuje postać analogia caritatis jako formy, w której najpełniej wyraża się relacja Boga do stworzenia ${ }^{56}$.

Wracając do rozważań czysto teoretycznych na temat interesującej nas nade wszystko metody filozoficznej Balthasara, trzeba ponownie podjąć próbę określenia jej charakterystyki formalno-historycznej. Metody, którą wydaje się posługiwać, nie można zapewne uznać za systematyczną - poprzez nadanie jej wyrazu analityczno-pojęciowego czy też konstruktywnego - a tym bardziej trudno przypisać jej charakter historyczny ${ }^{57}$. Można ją rozumieć w dużej mierze jako fenomenologiczne ujęcie różnorodności form myślenia ${ }^{58}$, zawierające wyraźne odniesienie do kategorii mitu i pojęcia formy.

W jednym z wywiadów, nawiązując do filozofii Karla Rahnera, Balthasar w następujący sposób opisuje swoje myślenie: „Uważam Karla Rahnera, ogólnie rzecz biorąc, za najtęższą teologiczną głowę naszych czasów. Jest oczywiste, że pod względem siły spekulatywnej o wiele mnie przewyższa. (...) Nasze pozycje wyjściowe były jednak właściwie zawsze różne. Jest książka Simmla pod tytułem Kant $i$ Goethe. Rahner wybrał Kanta, lub jeśli Pan woli, Fichtego, podejście transcendentalne. A ja - jako germanista - wybrałem Goethego; jego pojęcie postaci, jedno-

56 Por. M. Lochbrunner, Analogia caritatis. Darstellung und Deutung der Theologie Hans Urs von Balthasars, Herder, Freiburg-Basel-Wien 1981; M. Albus, Die Wahrheit ist die Liebe: zur Unterscheidung des Christlichen nach Hans Urs von Balthasar, Herder, Freiburg im Breisgau 1976.

${ }^{57}$ Por. P. Henrici, O filozofii Hansa Ursa von Balthasara, dz. cyt., s. 159161.

58 Przedstawiając zamysł powstania Chwały, Balthasar wyjaśnia swoje rozumienie pojęcia „estetyki teologicznej” i tłumaczy, iż dla jego metody „można poprowadzić pewną paralelę do fenomenologicznej metody Schelera, jak długo ta zmierza do czystego oddania się obiektu"; H.U. von Balthasar, Wiarygodna jest tylko miłość, dz. cyt., s. 17. 
razowej i niepowtarzalnej, organicznej, postaci rozwijającej się - myślę tu o Metamorfozie roślin Goethego - tej postaci, z którą Kant nawet w swej estetyce nie daje sobie rady" ${ }^{59}$.

Pojęcie postaci, która z każdej strony wydaje się inna, a cały czas promieniuje pełnym światłem bytu, stanowi wprowadzenie w świat różnorodności spostrzeżeń tej samej rzeczywistości. Na początku Apokalypse Balthasar tak charakteryzuje swoje myślenie: „Specyfiką niniejszych studiów jest (...) budowanie z historycznych struktur światopoglądowych, jak z pojedynczych kamieni, budowli, która ma sens pozahistoryczny" 60 . Sens ten ma zostać wydobyty poprzez filozoficzną refleksję, ale nie może zostać ograniczony systematycznym myśleniem, które nie pozwalałoby niejako transcendować uwarunkowań historycznych. Balthasar zdaje sobie sprawę, że potrzebuje pewnego dystansu do budowania systemu opartego na absolutności rozumu, podobnego do zamierzeń Hegla. Dlatego też wie, że struktury „znajdują się (...) między historią a systemem, w punkcie centralnym, który tylko dlatego różni się od Hegla, że owo centrum między »obiektywne « a »subiektywne « wydaje im się w najwyższym stopniu niestałe, typowe właśnie dla istot stworzonych - a więc centrum tego, co mityczne, nie zaś centrum ducha absolutnego (...). W gruncie rzeczy jest to więc niedająca się obecnie zatracić metoda fenomenologiczna, wypróbowana na samych przywódcach niemieckiego życia duchowego, wsłuchiwanie się, które, jak już wspomniano, właśnie wtedy jest pasywno-obiektywne, jeśli jest jednocześnie także twórczo-spoglądające" ${ }^{61}$.

${ }^{59}$ Duch i ogień. Rozmowa Michaela Albusa z Hansem Ursem von Balthasarem, dz. cyt., s. 92.

${ }^{60}$ AP I, s. 10, przyp. 2.

${ }^{61}$ Tamże. Przedstawiając jedną z części swojej trylogii, Balthasar napisze: „Głównym postulatem mojego dzieła Chwała była zdolność zobaczenia »postaci« w jej nierozerwalnej całości: spojrzenie Goethego miało zostać za- 
Balthasarowskie postulaty myślenia fenomenologicznego, które jego zdaniem odpowiadają całej tradycji chrześcijańskiej, występują przede wszystkim przeciwko możliwości jednoznacznego określenia całej rzeczywistości za pomocą ogólnego pojęcia. W myśleniu bowiem jest taki moment, który „ciągle pozostaje poza pojęciem, który nie da się zawrzeć w pojęciu, a który mimo to udowadnia i uzasadnia pojęcie. Takie stanowisko jest także stanowiskiem całej tradycji chrześcijańskiej"62. Fenomenologiczne ujęcie rzeczywistości niesie ze sobą przede wszystkim opisanie form (Gestalten). Formy jednak nie są wyłącznie sumą elementów tworzacycych całość. We wprowadzeniu do Origenes. Geist und Feuer formułuje Balthasar następującą myśl: „Ze wszystkich dzieł dokonać wyboru tego, co dziś jeszcze ma znaczenie, w taki sposób, aby we wzajemnym związku najistotniejszych fragmentów jak w mozaice ukazało się prawdziwe oblicze Orygenesa. (...) Przez to jednak, że w Orygenesowym myśleniu poszukujemy wewnętrznych »duchowych więzów «, stajemy już w oczywisty sposób poza zainteresowaniem czysto historycznym (...) i w przestrzeni nauk humanistycznych wznosimy posag, za którego ważność musimy ponosić odpowiedzialność”,

stosowane w stosunku do fenomenu Jezusa i konwergencji teologii nowotestamentowych"; H.U. von Balthasar, Unser Auftrag, dz. cyt., s. 32.

62 OZFK, s. 63. Każdy fenomen bytu „ma swoje wymiary i perspektywę, nie wyrazi go żadne pospiesznie sformułowane pojęcie. Chce on, aby chodzono wokół niego jak wokół statuy, która z każdej strony ujawnia coś nowego, wcześniej niewidzianego, i która z żadnego ujęcia nie ukazuje się całkowicie i ostatecznie"; H.U. von Balthasar, Geeinte Zwienatur. Eine philosophische Besinnung, Manuskript, Archiv Hans Urs von Balthasar, Basel, s. 8, cyt. za: J. Disse, Metaphysik der Singularität. Eine Hinführung am Leitfaden der Philosophie Hans Urs von Balthasars, Passagen Verlag, Wien 1996, s. 72.

${ }^{63}$ H.U. von Balthasar, Origenes. Geist und Feuer. Ein Aufbau aus seinen Werken, dz. cyt., s. 16. 
Formy są całościami, które nie dają się, historycznie rzecz biorąc, ująć bez jakiegoś centrum. Punktem wyjścia jest bez wątpienia bogata w treść całość myślenia, będąca jednocześnie owym centrum, drogę myślenia stanowią jednak różnorodne formy jego opisania. Każda z tych form żyje przecież z konkretnego królestwa treści. Przejście od centrum do form zmierza jednak w kierunku przeciwnym, można by rzec dialektycznie, na powrót do punktu wyjścia. Trudna oczywiście pozostaje odpowiedź na pytanie, jak dalece postrzeganie formy oddala nas lub przybliża do samego centrum i całościowego ujęcia rzeczywistości. Balthasar jest świadomy takich trudności: „Po pierwsze, będzie można ciągle zarzucać tej metodzie, że za każdym razem zakłada to, co należałoby udowodnić - jeżeli w ogóle kiedykolwiek można byłoby udowodnić »całość «, która przecież dla krytycznego rozumu pozostaje zawsze czymś »niezmiernym«. (...) Nie stosujemy bowiem żadnej innej metody (...) niż tę wychodzącą od widzenia, rozważania i uznania całości" ${ }^{64}$. Pojęcie centrum będzie musiało być ostatecznie związane z myśleniem teologicznym, a dokładniej z chrystocentrycznym rozumieniem prawdy jako centrum świata.

Fenomenologiczny sposób ujmowania rzeczywistości nie pozwala zatem jednoznacznie odwołać się do historyczno-analitycznego bądź też pojęciowo-konstruktywnego charakteru myślenia Balthasara. Poszczególne formy myślenia oderwane od centrum wydają się nie mieć same w sobie wielkiego znaczenia. Dopiero całość otwiera na pełne rozumienie, gdyż świat „,przypomina wielką orkiestrę, strojącą swoje instrumenty; każdy rzępoli po swojemu. (...) Na fortepianie zostaje jednak podane A, wokół którego tworzy się pewien jednolity nastrój: strojenie zmierza ku czemuś wspólnemu. Również wybór znajdujących się instrumentów nie

${ }^{64}$ Tenże, Klarstellungen. Zur Prüfung der Geister, Herder, Freiburg 1971, s. 15 . 
jest przypadkowy, poprzez wzajemne zróżnicowanie swoich właściwości tworzą one coś w rodzaju układu współrzędnych. (...) Wybór został dokonany z punktu widzenia jedności, która tymczasem spoczywa bezdźwięcznie w rozłożonej partyturze; jednak niebawem, gdy uderzy dyrygencka batuta, jedność przyciąnnie wszystko ku sobie, porwie ze sobą wszystko i dopiero wtedy będzie można zobaczyć, w jakim celu każdy jest tu obecny"65.

Istotnym momentem jest jednak sam ruch myślowy poszczególnych form, w nim bowiem ukazuje się pewnego rodzaju sens rozumienia. Balthasar chce widzieć siebie poza tym ruchem. Odczytuje sens historii nie na podstawie własnych sądów i posiadanej wiedzy, ale pozwala działać historii i różnorakim formom rozumienia rzeczywistości wokół siebie, zdobywając w ten sposób bogatą wiedzę ${ }^{66}$. Nie trzeba w tym celu jak Hegel włączać historii do królestwa konieczności. Świadomość faktu, że poznaje się zarówno historyczność bytu jako podstawową kategorię ontologiczną, jak i znaczenie historii dla bytu, prowadzi do większej spoistości, a także poszerzenia pola filozofii przez naświetlenie promieniem metafizyki tego, co indywidualne.

Można by powiedzieć, że w takim sposobie tworzenia sądu o rzeczywistości tkwi w ogóle geneza Balthasarowskiej filozofii; otworzyć się na działanie wielkich wydarzeń historii, przyjąć sposób myślenia wielkich jednostek, a jednocześnie mieć zdolność twórczej konfrontacji zdobytego doświadczenia z własnym sposobem postrzegania świata. Wolność własnego sposobu myślenia tworzy formy innego, często przeciwstawnego pojmowania rzeczywistości. Balthasarowskie myślenie definiuje się często

${ }^{65}$ Tenże, Prawda jest symfoniczna, tłum. I. Bokwa, Poznań 1998, s. 5-6.

${ }^{66}, \mathrm{~W}$ historii istnieje już tak wiele rzeczy, przemyślano już tyle spraw, które można owocnie przejąć z tradycji, o ile się je tylko w pewnym stopniu przetransponuje dla potrzeb współczesności"; Duch i ogień. Rozmowa Michaela Albusa z Hansem Ursem von Balthasarem, dz. cyt., s. 88. 
$54 \quad$ Hans Urs von Balthasar wobec idealizmu niemieckiego

w tej innej, odwrotnej formie widzenia i opisywania historii ${ }^{67}$. Ostatecznie Balthasar postrzega myślenie filozoficzne w świetle Objawienia, jako świadome i nieświadome zbliżanie się do niego.

\section{Idealistyczna forma myślenia. Plotyn}

Balthasarowska myśl filozoficzna tkwi mocno w tradycji filozofii neoplatońskiej. Pierwsze bliskie spotkanie z nią sięga czasu studiów filozoficznych Balthasara w Wiedniu. Tam słuchał wykładów Hansa Eibla o Plotynie. W Apokalypse der deutschen Seele i potem w Chwale ukazuje w świetle filozofii plotyńskiej Fichtego, Schellinga, Bergsona, Eriugenę i Kuzańczyka. Fascynuje go plotyńska teoria emanacji i koncepcja Jednego jako podstawy świata ${ }^{68}$. U Plotyna zostaje przełamany metafizyczny dualizm, który wyraźnie oddzielał od siebie świat i Boga. Wydaje się, że zmysłowa zasada świata zanika i ustępuje miejsca elementowi boskiemu. Plotyn jest dla Balthasara filozofem i teologiem jednocześnie. W filozofii Plotyn dostrzega zespolenie wszystkich wartości mitu i religii, widzi ją jednocześnie jako namiętny powrót do źródeł, gdzie wszystko, co istnieje, powiązane jest jeszcze wzajemnie ze sobą. „Dla Plotyna bycie samo jest boskie, zaś jego całkowite objawienie jest tak porywająco wspaniałe, że przyćmiewa bezmiernie wszystkie wspaniałości poszczególnych mitów" ${ }^{69}$.

Plotyn stanie $u$ początków nie tylko Balthasarowskiego estetycznego patrzenia na świat. Jego myśl znajdzie kontynuację

${ }^{67}$ Por. P. Henrici, O filozofii Hansa Ursa von Balthasara, dz. cyt., s. 160161.

68 Por. T. Krenski, Hans Urs von Balthasar. Das Gottesdrama, Matthias Gründewald Verlag, Mainz 1995, s. 35-36.

${ }^{69} \mathrm{CH}$ III/1/1, s. 251. 
w rozważaniach Balthasara o idealizmie niemieckim. Plotyn mówi o powrocie wszystkiego do Jedna, ale nie poprzez zniszczenie świata, lecz poprzez zrozumienie, czym jest piękno, będące pochodną Jedna, ponieważ „wszelkie piękno jest późniejsze od Niego (Jedna) i od Niego pochodzi, podobnie jak całe dzienne

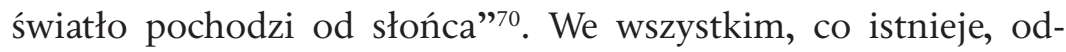
naleźć można ślady Jednego. Pozytywne spojrzenie na element tego, co skończone, przezwycięża dialektyczne napięcie wynikające z dualizmu świata i Boga, natury i łaski, duszy i ciała, ziemi i nieba. Jedno może ostatecznie ujawnić się w tym, co skończone. Dlatego też to, co skończone, może stać się pośrednikiem boskiego Objawienia: „Biada tym, którzy uważają jak gnostycy, że krytykując świat, należy też poddać krytyce jego stwórcę, zaś okazywanie czci bogu polega na odwróceniu się plecami do rzeczywistości świata" "11. Dla Plotyna spojrzenie w gwiazdy nadal w bezpośredni sposób ujawnia pewność boskości świata. Pozytywne wejrzenie na to, co skończone, otwiera możliwość boskiego Objawienia tego, co nieskończone, w różnych formach skończonego ${ }^{72}$.

Niemniej jednak harmonia między tym, co boskie, a tym, co ludzkie, pozostaje ukryta $\mathrm{w}$ nieprzezwyciężonej różnicy między źródłem a strumieniami. Balthasar napisze: „Dopiero Plotyna światło wschodzi na nowo i wspaniale, podczas gdy duch (świat idei) w niesłychany dotychczas sposób poruszany jest przez Erosa niezaspokojonej i równocześnie dopełnionej tęsknoty: ku temu, co niedające się pomyśleć, jedyne, będące samym dobrem, źródłu wszelkiego piękna, chociaż ono samo »nie raczy być piękne«. Myślenie i miłość są tutaj jednym, zaś obydwa stanowią światło

70 Tamże, s. 275. Por. Plotyn, Enneady, tłum. A. Krokiewicz, Akme, Warszawa 2000-2004, VI 9 (9) 4, w. 10-11.

71 Tamże, s. 253.

72 Por. T. Krenski, Hans Urs von Balthasar. Das Gottesdrama, dz. cyt., s. $35-37$. 
świata, światło to jednak tryska z tego, co niedostępne, co jako bezdenna podstawa i źródło jest brakiem światła, bądź ciemnością, bądź nad-światłem. Bez wątpienia byt został tutaj zrównany z myśleniem, lecz oba istnieją z łaski Jedni, oba również, na ile są erotyczne, przeniknięte są nicością (nauka o inteligibilnej materii) i tylko w ten sposób oba stanowią rodzący fundament dla bytów istniejących jako »dusza $\ll \mathrm{i} »$ natura «"73.

Pojawia się w tym miejscu filozoficzne pytanie: czy u Plotyna doświadczenie Boga jest czymś więcej niż samodoświadczeniem ducha w sobie? „Jeśli umysł w swojej nieskończonej aktywności poszukuje poprzez wszelkie przedmioty myśli Jedni, powraca w końcu ku tożsamości konfrontacji ze sobą samym: czy zatem znalazł to, czego szukał? Skoro myślenie (a tym samym umysł, nous) jest i pozostaje wtórne, wówczas musi ono z całą pewnością przekroczyć samo siebie; lecz jeżeli owo przekroczenie określimy mianem Erosa, który myślenie wprawia w ruch, czy wtedy ów Eros jest czymś więcej niż samo myślenie, czy też tylko jego wewnętrzną dynamiką? Czy Plotyński nous w swojej nieustannie przywracanej tożsamości z bytem jest »szczęśliwym bogiem «, czy też sytuuje się po stronie tego, co jest nie do końca boskie, czego ruch $\mathrm{w}$ stronę Jedna pozostaje nieukojoną tęsknotą, aż zostanie ona wypełniona przez Jedno?"74.

Balthasar rozumie myśl Plotyna jako element łączący ze sobą greckie mity i filozofię, element, poprzez który dociera się do lepszego rozumienia chrześcijańskiego pojęcia Boga i teologii stworzenia. Absolut rozumiany jest jako dające się dobro. We wszystkim, co żyje, we wszelkim pięknie, odkrywanym w muzyce i literaturze, widzi Balthasar dającą się dobroć i chwałę. Muzyka i literatura objawiają to, co boskie. Element boski pozo-

\footnotetext{
${ }^{73} \mathrm{CH}$ III/1/2, s. 579.

${ }^{74} \mathrm{CH}$ III/1/1, s. 265.
} 
staje jednak ponad wszystkim i dlatego w swej wzniosłości może zaistnieć ponad tym, co skończone, i jednocześnie wewnętrznie jakby w rzeczach skończonych, do tego w sposób niezmiernie intensywny, przerastający każdą bliskość możliwą między ludźmi. Balthasarowska nauka o Trójcy Świętej wyjaśnia dokładnie, jak Bóg, który jest dającą się dobrocią, może w wolności dawać dobroć. W związku z tym otwarte pozostaje pytanie, czy spadkobiercy i następcy filozofii plotyńskiej zwrócą swe myślenie w kierunku filozofii tożsamości (Hegel), czy też rozwiną myśl Plotyna ujętą jako możliwość zrozumienia różnicy pomiędzy Duchem a Jednością. Jest to dla Balthasara zadanie na miarę „nowożytnego rozstrzygnięcia"75. Plotyńskie zadanie wyjaśnienia boskiej nowiny, która wypływa z centrum i głębi samego bytu, wydaje się skierowane do tych, którym dane jest oglądać chwałę Boga w pierwiastku cielesnym, chrześcijanom: „Ich bowiem powinnością będzie odkrycie Boga we wszystkich rzeczach"76. Balthasar zauważa, że wzniesienie się ponad byt nabiera już nie filozoficznego, lecz teologicznego charakteru. Ten zaś zanika w wykładni nowożytnej i idealistycznej. Wprawdzie niektóre momenty pojawią się ponownie w filozofii późnego Schellinga i Fichtego, ale nie przyjmą jednoznacznej, zadowalającej Balthasara postaci ${ }^{77}$.

\footnotetext{
${ }^{75}$ CH III/1/1, s. 269.

76 Tamże, s. 270.

${ }^{77}$ Por. tamże.
} 
- 


\section{II \\ Eschatologia i mit. Apokalypse der deutschen Seele}

Balthasarowska analiza niemieckiej literatury i filozofii przyjmuje od samego początku charakter religijnego a priori z wyraźnym rysem eschatologicznym ${ }^{1}$. W sposób filozoficzno-historyczny patrzy Balthasar na rozwój niemieckiej filozofii ducha. Najważniejsze formy tej historii próbuje przedstawić w postaci pojedynczych, monograficznych studiów dotyczących przede wszystkim takich autorów, jak Lessing, Herder, Kant, Fichte, Schelling, Novalis, Hölderlin, Schiller, Goethe, Jean Paul, Hebbel, Wagner, Kierkegaard, Nietzsche, Bergson, Dostojewski, Husserl, Scheler, Heidegger i Barth.

Perspektywa prawdziwego zrozumienia istotnych momentów przyjmuje od początku charakter egzystencjalny. Wyraża się

${ }^{1}$ Por. A.M. Haas, Zum Geleit, w: H.U. von Balthasar, Apokalypse der deutschen Seele. Studien zu einer Lehre von letzten Haltungen, Bd. I, Johannes Verlag Einsiedeln, Freiburg 1988, s. XXXII. 
on przede wszystkim w postaci aktu historycznego, w myślowej formie jedności spojrzenia na całość rzeczywistości historycznej. Takie podejście mogłoby sugerować próbę zbudowania pewnego systemu prawdy historycznej. Balthasara interesuje jednak przede wszystkim możliwość wyraźnego, niejako czasowego spojrzenia na całość historii, i to w perspektywie jej rzeczywistości teologiczno-eschatologicznej. W takiej też perspektywie spojrzenie na filozofię idealizmu niemieckiego nabiera szczególnego charakteru.

\section{Apokalypse der deutschen Seele. Powstanie dzieła}

Apokalypse der deutschen Seele. Studien zu einer Lehre von letzten Haltungen stanowi pierwszą obszerną publikację Balthasara. Jest kontynuacją i jednocześnie nowym ujęciem opublikowanej w roku 1930 pracy doktorskiej Geschichte des eschatologischen Problems in der modernen deutschen Literatur, na podstawie której Balthasar, składając w 1928 roku egzaminy z filozofii i germanistyki na uniwersytecie w Zurychu, otrzymał tytuł doktora. Praca została napisana pod kierunkiem germanisty Roberta Faesiego, który wyraził się o niej następująco: „Dzieło Balthasara jest dziełem, które stawia wysokie wymagania, ale i wysokie wymagania spełnia"2. Ostateczne opracowanie tego samego materiału $\mathrm{w}$ trzech tomach powstałych w latach 1937-1938 przynosi przede wszystkim poszerzenie i pogłębienie filozoficznego tła dysertacji. W roku 1945 Balthasar tak napisze o swoim dziele: „Tak powstały owe trzy dziwne grube księgi o podobnie dziwnym tytule: Apokalypse der deutschen Seele. Studien zu einer Lehre von letzten Haltungen, które, ku niekłamanemu zdziwieniu wszystkich rze-

${ }^{2}$ R. Faesi, „Apokalypse der deutschen Seele”, „Neue Zürcher Zeitung” 1937, nr 1382. 
telnych fachowców, podjęły się przedstawienia w perspektywie chrześcijańskiej całościowej interpretacji poezji, filozofii i teologii od Lessinga do dnia dzisiejszego. Chętnie przyznaję, że i mnie to gigantyczne dziecko wydaje się trochę niesamowite; kiedy widzę je na półce, często zadaję sobie pytanie, cóż w nim może być. Możliwe, że za dużo - ale niektóre rzeczy zostały przecież wtedy napisane krwią serdeczną"3.

Przedstawienia w chrześcijańskiej perspektywie ponad 700 lat z niemieckiego życia duchowego dokonuje Balthasar w czterech fazach ${ }^{4}$. Pierwsza, zatytułowana „Początek” (Einstieg) obejmuje czas od średniowiecza do początku czasów nowożytnych i zdominowana jest przez mit Chrystusa ${ }^{5}$. W ten sposób jedność punktu eschatologicznego oznacza wewnętrzny ruch, który obejmuje zarówno podłużne, jak i poprzeczne linie historii. Tę pierwszą fazę Balthasar poprzedza historią wstępną, szkicując chrześcijański obraz świata, w którym indywidualna eschatologia ludzkości i natury są ze sobą nierozerwalnie złączone, a harmonia ciała i duszy otrzymuje uzasadnienie w zmartwychwstaniu Chrystusa jako osoby duchowej i cielesnej. Harmonia ta zostaje osłabiona w cza-

${ }^{3}$ H.U. von Balthasar, Hans Urs von Balthasar przedstawia siebie, w: OMD, s. 11. Kilka lat później doda: „Z niektórymi kwestiami z tej zapomnianej książki zgadzam się jeszcze i dzisiaj; bez trudu można odnaleźć miejsca, w których zostałem poruszony najgłębiej: przez późnego Fichtego, Novalisa i Hölderlina oraz ciągle na nowo przez Goethego"; H.U. von Balthasar, Krótki przewodnik po moich ksiażkach, w: OMD, s. 31.

${ }^{4}$ Por. A.M. Haas, Zum Geleit, dz. cyt., s. XLI, oraz W. Löser, Im Geiste des Origenes: Hans Urs von Balthasar als Interpret der Theologie der Kirchenväter, Josef Knecht, Frankfurt am Main 1976, s. 46-50.

${ }^{5}$ Nawet jeśli można dostrzec pewne wyraźne linie przebiegu wydarzeń historycznych, to jednak według Balthasara uchwycenie całości elementu historycznego wydaje się poza możliwościami człowieka. „A jednak cały ten splot szybko prowadzi w ciemność niezbadanego wyroku Boskiego jako nieprzekazanego dotąd żadnemu stworzeniu klucza do wszelkich eschata"; AP I, s. 23. 
sie reformacji i humanizmu oświeceniowego poprzez zagubienie transcendencji i zwycięstwo immanencji. Bóg nie jest już bytem, lecz ideałem, do którego zbliżamy się w nieskończonym postępie. Podmiotowa transcendentalność Herdera i Kanta nie jest w stanie odzyskać autentycznego doświadczenia tego, co nadprzyrodzone. Świat nadprzyrodzony pozostaje jedynie snem i niezrealizowanym dążeniem. Według Balthasara, kantowska eschatologia pozostaje pomiędzy tym, co immanentne i transcendentne, dlatego też jest daleka od chrześcijańskiej wizji Wcielenia.

Druga faza, „Ogląd świata” (Weltschau), przedstawiająca historię w świetle mitu Prometeusza, obejmuje czas od humanizmu i reformacji do XIX wieku, kładąc wyraźny akcent na interesującą nas tutaj historię idealizmu niemieckiego. Myślowy ruch idealizmu zmierza ku temu, co wewnętrzne. Świat, przyroda, przedmiot stają się zwierciadłem tego, co wewnętrzne, podmiotu. Człowiek jest miejscem, do którego wszystko zmierza, jednocześnie jednak staje się początkiem zrozumienia świata. Wraz ze światem jest wewnętrznie skierowany ku Bogu, z Nim zaś jest wewnętrznie skierowany ku światu. Zasadę prometejską odnajduje Balthasar u Goethego. Prometeusz jest prawdziwym demiurgiem, który tworzy reguły życia świata. Zmieszanie tego, co boskie i ziemskie, jest wydarzeniem nieskończonym, które zostaje zapośredniczone przez człowieka rozumianego jako środek klepsydry. „Jako świat wydobywa on ogień z głębi boskiego ducha, jako duch odsłania iskrę ducha w głębi przyrody"6. W umiejętności Goethego ukazania współbrzmienia natury i życia widzi Balthasar punkt wyjścia do wskazania drogi, która zakorzeniona mocno w tym, co ziemskie, prowadzi ku temu, co ponad nią. Zakochany w myśli Goethego Balthasar nie darzy sympatią Hegla i jego dziedzictwa. Racjonalizm poznania, w którym Hegel widzi syntezę ludzkich

${ }^{6}$ AP I, s. $155-156$. 
możliwości, wydaje się wolą panowania nad miłością. Cała tradycja chrześcijańska przybiera postać karykaturalną. Objawienie i wiara są momentami przejściowymi, a ofiara absolutną przebiegłością.

Nietzsche i Kierkegaard to temat trzeciej fazy, zdominowanej przez mit Dionizosa. Stanowią oni, według Balthasara, punkt zwrotny $\mathrm{w}$ historii eschatologii. Polega to na spotkaniu i walce dwóch postaci: Chrystusa i Dionizosa. Konfrontacja postaw obejmuje czas najnowszej historii od Kierkegaarda do Nietzschego i kończy eschatologię znaczoną mitem Prometeusza. Mit Dionizosa oznacza przede wszystkim postawę ostateczną człowieka, który akceptując własną egzystencję, żyje w ciągłej sprzeczności, dialektycznym rozdarciu. Dlatego też, według Balthasara, „tego, co »ostateczne «, czyli »eschatonu « człowieka i świata, nie powinno się już szukać poza tezą i antytezą, lecz bardzo dokładnie w polu walki samych tych przeciwieństw"”.

Wreszcie czwarta faza to możliwość nowej nadziei w micie Chrystusa. Tym samym pojawia się obraz eschatologii chrześcijańskiej, w której Balthasar pragnie uchwycić to, co pierwotnie konkretne. Eschatologia ta konstruuje siebie, wychodząc zdecydowanie od elementów teologicznych. Zostaje ona przedstawiona

${ }^{7}$ AP II, s. 6. Dionizos jest „ukrzyżowanym Dionizosem”. Jego postać określa według Balthasara nowy porządek: „Układ taki jest w swej przedmiotowości jednocześnie także historyczny. Jeśli ogarniamy wzrokiem czasy od Nietzschego do roku 1930 (...), wówczas »pojedynek« między Kierkegaardem a Nietzschem przybiera całkowicie historyczną postać: interpretacja świata od Nietzschego do wojny stoi zupełnie pod znakiem Nietzschego, od wojny do roku 1930 - pod znakiem Kierkegaarda. (...) Ponieważ podstawowym słowem Nietzschego jest »życie «, a podstawowym słowem Kierkegaarda »duch «, to czasy od Nietzschego do wojny stanowią pełne rozwinięcie problematyki »życia «, zaś czasy od wojny do roku 1930 takie samo rozwinięcie problematyki »ducha«. Oba jednak tylko w sensie pewnej prewalencji i w taki sposób, że jedno zawiera w sobie drugie"; tamże, s. 12 . 
w przestrzeni czysto biblijnej, w której nie traktuje się jej tylko jak zwykłą chrześcijańską „naukę o końcu”, lecz „mowa o końcu jest w sposób bezpośredni słuchana, przeżywana i realizowana. Jedynym punktem centralnym wszelkiej eschatologii chrześcijańskiej jest sposób, w jaki Chrystus stoi u końca"».

\subsection{Krytyczna analiza literacka dzieła}

Tekst Apokalypse niesie ze sobą wiele kontrowersji zarówno natury filologicznej, jak i metodologicznej ${ }^{9}$. Opinie o dziele w środowisku filologicznym były dosyć podzielone, jednak raczej przychylne zarówno jeśli chodzi o warstwę literacką, jak i treściową. W jednej z recenzji wydanej krótko po publikacji Apokalypse filozof Otto Friedrich Bollnow, wskazując na podstawową jej tematykę, pisał: „Chodzi o szeroko zakrojoną i dzięki dogłębnej interpretacji szczegółowo przeprowadzoną konfrontację stanowiska katolickiego z całą historią myśli o immanencji, to znaczy z dążeniami zmierzającymi do zrozumienia świata i życia wyłącz-

${ }^{8}$ AP I, s. 8.

9 Obszerną literaturę na temat literackiego odbioru dzieła Balthasara podaje Alois M. Haas we wprowadzeniu do Apokalypse (por. A.M. Haas, Zum Geleit, dz. cyt., s. XXXIV-XXXV). Spośród różnych opinii znana jest m.in. dość niesprawiedliwa i krzywdząca ocena Theodora Haeckera: „Die Apokalypse der deutschen Seele jest jeszcze bardziej żenująca niż bajoro Sörgela, rości sobie bowiem całkiem inne pretensje! Porównanie Georgego z Izajaszem, tak jest - z Izajaszem, jest strasznym bluźnierstwem. Nie, byłoby nim, gdyby ów człowiek osiągnął taki poziom, ale tego nie czyni. A zatem to tylko gadanina. To nawet nie jest »literatura «, która zakłada pewne poczucie jakości. Tego właśnie mu brakuje. Nie potrafi napisać żadnego "zdania «"; Th. Haecker, Tag- und Nachtbücher: 1939 bis 1945, Suhrkamp, Frankfurt 1975, s. 240. 
nie na podstawie ich samych, z pominięciem komponentów transcendentnych"10.

Analiza poszczególnych twórców niemieckiej filozofii ducha ujawnia wprawdzie systematyczny i tematyczny zamiar, jednakże trudno ów zamiar Balthasara odróżnić od myśli omawianych autorów. Myśl jego kryje się często za fenomenologicznym przedstawieniem przedmiotu. Ponieważ w zamierzeniu Balthasara podjęte dzieło miało być konfrontacją chrześcijańskiego punktu widzenia z całością historii immanentnego widzenia rzeczywistości, próbą ukazania dążenia, rozumiejącego świat w aspekcie jego transcendentnego pochodzenia, pierwsze spojrzenie na filozofię idealizmu nie mogło mieć na celu jedynie opisowego, neutralnego przedstawienia myśli poszczególnych autorów, ale niosło ze sobą wyraźny rys osądu i analizy krytycznej, a „napiętnowana losem myśl niemiecka"11 miała zostać ukazana w perspektywie eschatologicznej.

\subsection{Historia jako eschatologia. Pojęcie mitu}

Wydaje się początkowo, że tematem zasadniczym Apokalypse jest eschatologia. „Apokalipsa duszy” jest według Balthasara „konkretnym słowem dla eschatologii”"12, jej celem zaś „»oświecenie « (Apo-kalypse), "przeinterpretowanie « tego, co światowe - w to, co chrześcijańskie, tego, co pozornie czysto naturalne - w nadprzyrodzone, tego, co przemijające i fragmentaryczne - w ostateczne"13. Balthasar używa słowa „eschatologia” w innym nieco znaczeniu,

${ }^{10}$ O.F. Bollnow, Hans Urs von Balthasar: Apokalypse der deutschen Seele.

2. und 3. Bd., „Die Literatur” 41 (1938/39), s. 761.

${ }^{11}$ H.U. von Balthasar, Retrospektywa, w: OMD, s. 36.

${ }^{12}$ AP I, s. 3.

${ }^{13}$ H.U. von Balthasar, Apokalipsa niemieckiej duszy, w: PW 1, s. 147. 
niż czyni to teologia czy eschatologia filozoficzna ${ }^{14}$. W teologii jest ono synonimem czasów ostatecznych, nasz autor zaś rozumie je w sensie greckiego słowa apokalyptein. „Apokalipsa” to odsłonięcie, stawanie się widocznym. Jeśli „apokalipsa” oznacza przede wszystkim „odsłanianie” tego, co ukryte, to Balthasar swoje zadanie widzi w zrozumieniu postawy eschatologicznej danej epoki. I nie chodzi w gruncie rzeczy o przedstawienie jedynie idei eschatologicznych danego czasu, ale o możliwość spotkania konkretnego człowieka, który staje wobec własnego przeznaczenia. „Apokalipsa duszy” oznacza odsłanianie jej ewentualnej umiejętności bycia całością, a więc „eschatologię” jako „naukę o stosunku duszy do jej wiecznego przeznaczenia, którego osiągnięcie (wypełnienie, upodobnienie się) jest jej apokalipsą" ${ }^{15}$. Apokalipsa duszy jest poza tym spojrzeniem na ,wiedzę o trwaniu konkretnego ducha wobec własnej ostateczności, dopełniającej go, ale jednak pozostającej dla niego zakrytą"16.

Innymi słowy, eschatologia jest nauką o tym, co ostateczne, nauką o stawaniu człowieka wobec swego eschatonu, wobec tego, co ostateczne i zewnętrzne ${ }^{17}$. Dostęp człowieka do ostatecznego celu otwiera się tylko w konkretnym historycznym momencie ludzkiej egzystencji. Człowiek stający wobec swojego przeznaczenia ma przed sobą zadanie odkrycia relacji „duszy”18 do

${ }^{14} \mathrm{Na}$ temat teologicznego pojęcia eschatologii w dziełach Balthasara por. I. Bokwa, Trynitarno-chrystologiczna interpretacja eschatologii w ujęciu Hansa Ursa von Balthasara, Wydawnictwo Diecezji Radomskiej AVE, Radom 1998. Obszerne opracowanie eschatologii filozoficznej można znaleźć w książce I. Ziemińskiego Życie wieczne. Przyczynek do eschatologii filozoficznej, W Drodze, Poznań-Kraków 2013.

${ }^{15}$ AP I, s. 4.

16 Tamże, s. 12.

${ }^{17}$ Por. tamże, s. 3.

18 „Mówimy tutaj »dusza« (a nie duch) nie w sensie rzeczywistości czysto »psychologicznej« czy »filozoficznej«, lecz po to, aby dotknąć tego, co 
jej wiecznego przeznaczenia. Relacja ta znajduje wyraz przede wszystkim w języku mitu, który stanowi dla Balthasara środek pomiędzy „czystym pojęciem” a „czystą naocznością”19. Jeśli człowiek zdaje sobie sprawę, że staje wobec swego przeznaczenia jak przed czymś, co ukryte, musi uświadomić sobie konieczność znalezienia środków dostępu do ukrytej rzeczywistości. Własne przeznaczenie może być wyrażone i przedstawione za pomocą obrazów, poprzez powrót do pojęcia mitu. W ten sposób Balthasar definiuje podstawowe zadanie swego dzieła: „Naszym pierwszym zadaniem będzie więc poszukiwanie ostatecznych postaw ducha niemieckiego, prowadzone zgodnie z myślą przewodnią eschatologicznej mitologii, którą ów duch stworzył jako zwierciadło i wyraz zrozumienia samego siebie"20. Dziedzina filozofii i jej próba systematycznego ujmowania historii przyjmuje charakter mityczny, dlatego też „filozofia jest ustawicznym otaczaniem pełni bytu obrazami istot, a przez to, jako aforyzm, sylogizm czy system, zawsze tylko namiastką tego, co ma się na myśli. Wszelkie myślenie ma tak bardzo wartość paraboli (przypowieści), iż zachowuje ją nawet wtedy, gdy wychodząc poza konstrukcje myślowe o konkretnej postaci, wysuwa już tylko otwarte kwestie i wątpliwości" ${ }^{21}$. Balthasar wkracza w strukturę dialektyczną, która ma historycznie i filozoficznie odpowiedzieć na podstawowe pytania dotyczące otaczającego nas świata i ukazać sposób formowania procesu poznawczego. Jest zarazem przekonany, że „»jak « i »dlaczego « mają w takim stawianiu pytań swoją własną, niedającą się pomylić z innymi postać, nacechowaną przez egzystencjalnego pytającego, pewien rytm myślowy, który zawsze daje się oddzielić

konkretno-ostateczne, a co wyraża ona choćby w zwrocie "ratować dusze« (zamiast »ratować ludzi « czy »duchy«)"; tamże, s. 4.

${ }^{19}$ Por. H.U. von Balthasar, Apokalipsa niemieckiej duszy, dz. cyt., s. 148.

${ }^{20}$ AP I, s. 8.

${ }^{21}$ Tamże, s. 9-10. 
od każdego »co« tego, co pomyślane, i który może jedynie dla siebie stanowić swój własny obraz, czyli mit"22.

W ten sposób Balthasarowska filozofia historii przyjmuje postać mityczno-egzystencjalnego oglądu elementu historycznego. Eschatologiczne przeznaczenie człowieka ma wymiar egzystencjalny, bowiem pojedynczy, konkretny człowiek w swym myśleniu i działaniu widzi siebie zawsze w perspektywie tego, co ostateczne. Eschatologia staje się mityczna w momencie, kiedy jednostka zda sobie sprawę, że w jej formie myślenia pojawia się horyzont człowieka jako takiego, a forma ta w sposób konieczny wprowadza go w sferę idei. Egzystencjalny charakter eschatologii staje się więc mityczny, gdy człowiek uświadamia sobie, że sam z siebie nie jest w stanie zrealizować swego przeznaczenia. Dusza staje wobec wielości możliwych obrazów, które niesie ze sobą historia. Człowiek może próbować w jakiś sposób je porządkować. Jednak „każda bezpośrednio-racjonalna wypowiedź o tym, co »ostateczne«, jest niemożliwa dla konkretu, ukrytego w swej istocie. Dotyka ona tylko pewnej prawdy ogólnej i abstrakcyjnej, pewnej rzeczowości, która w najlepszym wypadku sama znowu może być »mitem « dla tego, co ma się konkretnie wydarzyć"23.

Mityczność pojawia się w rozważaniach obok chrześcijańsko-biblijnego sposobu mówienia o Bogu ${ }^{24}$. Balthasar zdaje się wyraźnie optować za takim spojrzeniem, w którym ,jako najwyższa zakładana forma prawdy jawi się nie prawda pojęciowo-abstrakcyjna, lecz prawda karmiona i nasycona naocznością, która to prawda przez to także musi mieć charakter mniej lub bardziej historyczny" "25. Metoda, którą zamierza się posługiwać, ma polegać na przedstawieniu pod postacią mitu tego, co najważniejsze

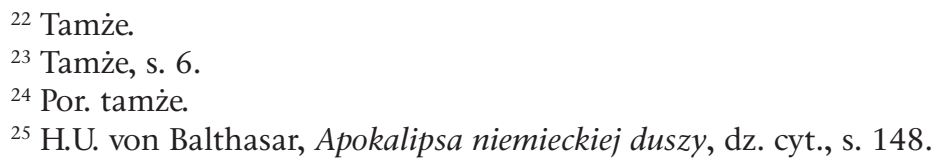

${ }^{25}$ H.U. von Balthasar, Apokalipsa niemieckiej duszy, dz. cyt., s. 148. 
w danej epoce, a mianowicie dążeń ku prawdzie. Balthasar chce jednocześnie odpowiedzieć na pytanie, w jaki sposób możliwy jest dialog między myślicielami chrześcijańskimi i niechrześcijańskimi. Uważa go za możliwy i owocny ,jedynie na płaszczyźnie, która zdaje się zawierać pełny wydźwięk ludzkiej prawdy, a mianowicie na płaszczyźnie »mitu«"26.

Czym dla Balthasara jest mit? To jednocześnie forma przedstawienia religijno-poznawczego oglądu rzeczywistości oraz postać prawdy, która „pozostając w jednakowej odległości od »czystego pojęcia « $\mathrm{i}$ »czystej naoczności «, jest wyrazem idei doniosłej światopoglądowo lub religijnie. Kant wyraźnie uznał owo bycie pośrodku za właściwy »środek « człowieka i z niego uczynił cel swojej myśli (między »pustym « pojęciem a »ślepą naocznością); środek ten był uważany za ideał zarówno przez filozoficzny idealizm, jak i przez niemiecki romantyzm (w »intuicji intelektualnej « Schellinga)" 27 .

Balthasar ukazuje zatem mit jako podstawową formę dążenia do prawdy, która jawi się nie tylko pojęciowo-abstrakcyjnie, ale karmi się naocznością, przybierając charakter historyczny.

Rozważania związane z mitem Prometeusza i Dionizosa doprowadzą Balthasara do ważnych stwierdzeń na temat idealizmu. Jest on jednak przekonany, że oba te mity obecne w ide-

${ }^{26}$ Tamże.

27 Tamże. Musi istnieć, według Kanta, pewna płaszczyzna, na której dokonuje się łączenie tego, co różnorodne. Jak pisze Aleksander Bobko, Kant wierzy, iż ,jest taki »punkt «, gdzie zbiegają się wszystkie nici tworzące racjonalną strukturę uniwersum, dzięki czemu możliwe jest naukowe poznanie (...). Ten »punkt « znajduje się w obrębie władz poznawczych podmiotu. To tam właśnie dokonuje się pierwotna synteza, której mechanizmy są potem niejako powielane w każdym konkretnym poznaniu zachodzącym na poziomie wyższym"; A. Bobko, Myślenie wobec zła. Polityczny i religijny wymiar myślenia w filozofii Kanta i Tischnera, Instytut Myśli Józefa Tischnera, Uniwersytet Rzeszowski, Kraków-Rzeszów 2007, s. 74. 
alizmie niemieckim nie są jedyną i całościową formą poznania. Chrześcijański punkt widzenia bowiem zmierza w jeszcze innym kierunku i może im przeciwstawić „bezpośrednio na pewno nie formę prawdy właściwą dla scholastycznego sposobu myślenia, lecz tylko sam jedyny, centralny »mit « chrześcijaństwa: wieczną Prawdę, która stała się ciałem, czasem, n a ocznością. Chrystus, jako »mit « we wspomnianym znaczeniu (który oczywiście w najmniejszym stopniu nie wyklucza realnej historyczności), może wejść w żywy dialog z ostatecznym mistycznym sensem idealizmu niemieckiego i filozofii życia, może okazać się ową konkretną rzeczywistością, o którą obu tym prądom chodziło w ich najgłębszych tęsknotach"28.

Apokalipsa jako objawienie ostatecznego celu jest pierwotnie ukazaniem konkretnego zdarzenia, przedstawieniem życia jednostki, a nie tylko abstrakcyjnym stwierdzeniem czy obiektywnym zbiorem przeżyć, wyrażającym to zdarzenie. Podstawowymi kategoriami tak rozumianej eschatologii są indywidualność i podmiotowość. Wynikają z tego dwa jej rodzaje: eschatologia egzystencjalna i pozytywna: „Z dwóch możliwych sposobów uprawiania eschatologii wybraliśmy tym samym jeden: zamiast eschatologii "pozytywnej ", »narracyjnej « eschatologię »mityczną «, »egzystencjalną «. Pierwsza z nich uprawiana jest jako nauka wśród nauk, żyje w medium historii, bada i zbiera źródła, w których narody snuły rozważania o śmierci i przemienieniu, o sądzie, pokucie i niebie (...). Szybko napotka przy tym formę mitu opanowującą wszystko, będzie kolekcjonowała i porządkowała obrazy oraz próbowała odgadnąć ich sens. (...) Porządkowanie tego wszystkiego, co ludzkość myślała o eschatonie, to byłaby eschatologia pozytywna, referująca" 29 .

\footnotetext{
28 Tamże, s. 149.

${ }^{29}$ AP I, s. 5-6.
} 
Pozytywna eschatologia niesie ze sobą jednoznacznie rysujące się granice. Racjonalna próba zrozumienia tego, co ostateczne, kończy się abstrakcyjnym pojęciem prawdy, pewnego rodzaju rzeczowością, która ponownie staje się przedmiotem mitu. Dlatego Balthasar stwierdza: „Pewną niedogodnością jest dla nas sumienie egzystencjalności, stanowiącej dokładną miarę żywotności eschatologicznej mityczności: mitologia dozwolona jest o tyle, o ile potrzebne są szata i wyraz dla żywego bytu. (...) Wyjaśni więc ona wszystko tak dalece, jak to wyjaśnia sytuacja, w której dusza zmierza ku swojej apokalipsie. Z uwagą spotkają się głównie (...) nie obiektywne, możliwe sytuacje i okoliczności z innego świata, lecz w tym wszystkim i poprzez to wszystko wartość wyrażenia tego, o co rzeczywiście chodziło: ich konkretne usytuowanie we własnej ostateczności. Nić prowadząca od obrazu do tego, co zobrazowane, nigdy nie może zupełnie się zerwać"30.

Eschatologia egzystencjalna, mityczna, którą Balthasar przyjmie później jako podstawową i prawdziwą, jest natomiast czymś innym niż tylko próbą naukowego, systematycznego podejścia do zrozumienia tego, co ostateczne. Jest nabrzmiałą subiektywnością. Każda dusza, według Balthasara, jest w stanie za pomocą zgromadzonych przez siebie obrazów historii, niejako wewnętrznie odczuwając swe konkretne przeznaczenie, odsłonić siebie i tym samym znaleźć się na drodze do jego wypełnienia ${ }^{31}$. Dusza bowiem „od »rzeczy ostatecznych «, o których teraz już wie i które interesują ją, bo wskazują na to, co w niej najgłębsze, utoruje sobie własną drogę do swego ostatecznego przeznaczenia"32. Jego pełne zrozumienie jest dla niej jednak nadal tylko niespełnio-

30 Tamże, s. 6-7.

31 „Również jednak pojedyncza dusza, zamykając oczy na ów ogromny natłok obrazów, może sama w swym wnętrzu przypomnieć sobie swój konkretny eschaton, możliwe drogi odsłaniania każdej duszy"; tamże, s. 6.

${ }^{32}$ Tamże. 
nym życzeniem, pewnym otwartym zamysłem. Pomocą w jego realizacji mogą stać się filozofia i sztuka, albo też sam Bóg, poprzez teologię, obdarzy duszę zrozumieniem jej przeznaczenia ${ }^{33}$. Filozofia, sztuka i teologia będą jednak wyłącznie środkami, mającymi ukazać i formułować myśl o tym, co ostateczne, nie są natomiast bezpośrednim językiem ujmującym rzeczywistość elementu ostatecznego ${ }^{34}$. Otwarte pozostaje pytanie, jak dalece taka próba wewnętrznego spojrzenia na możliwości jednostki wykracza poza krąg historycznej subiektywności, która nie zdoła przecież być jednocześnie przekonująco-obiektywną. Rozważania te prowadzą do konieczności wprowadzenia właściwego rozumienia pojęcia prawdy i rzeczywistości. Ostatecznie objawienie duszy możliwe jest jedynie w uprzednim, obejmującym wszystko, wewnętrznym i zewnętrznym objawieniu Boga. W ten sposób każda obiektywna eschatologia jest tylko momentem częściowym w obejmującym wszystko objawieniu duszy. Punkt wyjścia widziany w elemencie subiektywnym musi zostać zobiektywizowany. Moment decydujący tkwi jednak w możliwości wyjścia z eschatologii postawy duszy wobec jej ostatecznego przeznaczenia, wobec jej możliwości całości istnienia. Jest to o wiele bardziej właściwe, niż gdyby ów punkt znajdował się w obiektywnych możliwościach ostatecznych ${ }^{35}$.

${ }^{33}$ „Ponieważ jednak jej [duszy - przyp. M.U.] apokalipsa jeszcze nie nastąpiła, ponieważ zatem stoi sama przed sobą niczym przed zamkniętymi drzwiami, również logos własnego eschatonu może pojąć tylko w sposób zawoalowany. Czy sama go sformułuje (w filozofii bądź sztuce), czy też jako logos theou zostanie jej on wypowiedziany przez Boga (w teo-logii), będzie mogła go zrozumieć jedynie poprzez obrazy"; tamże.

34 Por. tamże.

35 „Objawienie duszy i objawienie Boga stanowią przez swoje ścisłe przyporządkowanie je dną tylko historię, jako przeskok iskry od środka bytu do środka bytu, a w nim jako prześwit centrów (...). Wszelka »obiektywna eschatologia jest rzeczywiście tylko częścią bardziej obszernego od- 
Warto już w tym momencie zaznaczyć, że zasadnicze, krytyczne pytanie dotyczące całego dzieła nie odnosi się jedynie do poszczególnych aspektów idealizmu, które Balthasar poddaje analizie, lecz winno dotykać przede wszystkim problemu mitycznego pojęcia prawdy i pojęcia świata, a w tym kontekście zagadnienia relacji natury i tego, co nadprzyrodzone.

\section{Ogląd i życie świata}

Perspektywa eschatologiczna i mityczna otworzyła zatem przed Balthasarem drogę myślenia, na której podjął się przedstawienia z chrześcijańskiej perspektywy ponad 100 lat niemieckiego życia duchowego, od oświecenia do czasów jemu współczesnych. W roku 1955, spoglądając wstecz na swoje dzieła, umieszcza tematykę Apokalypse w obszarze zadania, które trzeba podjąć w dialogu ze światem, aby znaleźć zrozumiały język do określenia miejsca i misji myśliciela chrześcijańskiego we współczesności. Wyjaśnia między innymi, że utajony dialog z Kierkegaardem i Dostojewskim otworzył niejako jego „sposób myślenia na »dialogiczność« między światopoglądami, zwłaszcza między chrześcijańskim i nie-chrześcijańskimi”"36.

Jak już wspomniano, Apokalypse miała być przede wszystkim próbą ponownego spojrzenia najpierw na idealizm niemiecki $\mathrm{w}$ szerokim znaczeniu tego pojęcia (przede wszystkim na filozofię i literaturę Lessinga, Herdera, Kanta, Fichtego, Schellinga,

słaniania duszy. (...) O ile punkt wyjścia od tego, co subiektywne, chociaż musi rozszerzać się na to, co obiektywne, jest jednak decydujący, to wychodzenie eschatologii od postawy duszy wobec jej ostatecznego przeznaczenia, wobec możliwości bycia całością jest bardziej słuszne i głębokie niż wychodzenie od »obiektywnych możliwości ostatecznych «"; tamże, s. 5.

${ }^{36}$ H.U. von Balthasar, Krótki przewodnik po moich książkach, dz. cyt., s. 31 . 
$74 \quad$ Hans Urs von Balthasar wobec idealizmu niemieckiego

Novalisa, Hölderlina, Schillera, Goethego, Jeana Paula i Hegla), następnie na historię filozofii życia z drugiej połowy XIX wieku (Bergsona i Klagesa, Georgego, Rilkego i innych), ze szczególnym uwzględnieniem konfrontacji pomiędzy filozofią Nietzschego i Dostojewskiego, oraz na nowożytną i współczesną filozofię egzystencji (Schelera, Husserla, Heideggera, Rilkego i Bartha). Balthasarowi chodzi nie o teoretyczną dyskusję, lecz o „wskazanie owego punktu, w którym - dobrowolnie lub w sposób wymuszony - następuje otwarcie się na to, co »ostateczne« (na Chrystusa)"37, na ostateczną prawdę o człowieku, która w swej istocie jest także ukrytą siłą napędową dzieł filozoficznych i literackich. W późniejszym okresie Balthasar napisze: „Kiedy zastanawiam się nad tematem mojej pracy doktorskiej i nad rozwiniętą z niej później Apokalypse der deutschen Seele, stwierdzam, iż podstawowym impulsem do ich powstania było pragnienie odkrycia $\mathrm{u}$ wielkich postaci współczesnej niemieckiej historii ducha ich ostatecznej, często ukrytej postawy religijnej (apokalyptein znaczy przecież »odsłaniać, odkrywać«), a zatem niejako pragnienie nakazania im szczerej spowiedzi" ${ }^{38}$. Myśl ta niosła ze sobą także chrześcijańskie przesłanie filozofii jako nauki w świecie współczesnym. Balthasar jest przekonany, że filozof nie może umieścić swego myślenia w jakiejś niezależnej, specjalnej sferze, lecz zawsze stoi w centrum chrześcijańskiego posłannictwa. „Jeżeli rzeczywiście jest myślicielem chrześcijańskim, nie może swemu myśleniu nadać innego ostatecznego sensu" 39 .

37 Tamże.

${ }^{38}$ Tenże, Unser Auftrag: Bericht und Entwurf, Johannes Verlag, Einsiedeln 1984, s. 32; por. tenże, Prüfet alles - das Gute behaltet. Ein Gespräch mit Angelo Scola, Johannes Verlag Einsiedeln, Freiburg 2001, s. 11.

${ }^{39}$ OZFK, s. 24. 


\subsection{Dialektyka idealizmu niemieckiego}

Idealizm niemiecki od samego początku zmierzał do zbudowania systemu obejmującego całość rzeczywistości ${ }^{40}$. Systemu, który łączyłby trwanie poszczególnych rzeczywistości człowieka w jedną twórczą całość. Aktywność ludzkiego podmiotu zmierza do ujęcia całej rzeczywistości, aż po rozumienie świata jako produktu tejże aktywności. Z drugiej strony, idealizm szuka możliwości przezwyciężenia tego wewnętrznego procesu. Balthasar odrzuca zdecydowanie te idealistyczne dążenia, które chciałyby widzieć świat jedynie poprzez pryzmat własnej aktywności podmiotu. Linie rozwoju myśli idealistycznej (jedna wychodząca od natury w kierunku ducha i druga, przeciwna, rozpoczynająca od ducha i zmierzająca ku naturze) zostają w sposób systematyczny włączone w ruch dialektyczny, obejmujący całą rzeczywistość stworzoną. Jedynym pośrednikiem owej dialektyki wydaje się człowiek.

Balthasar uważa, że rozerwana eschatologiczna jedność średniowieczna zostaje zdominowana przez niechrześcijański horyzont myśli spekulatywnej, właściwej dla idealistycznej filozofii niemieckiej. Rozważania związane z niemiecką filozofią ducha poprzedza w Apokalypse der deutschen Seele krótki rozdział przedstawiający czas reformacji ${ }^{41}$. Balthasar rozpoczyna go od stwierdzenia, że nauka Lutra ukazała wyraźnie rozdzielenie natury i ducha. W ten sposób eschatologiczne rozumienie natury jako

40 Por. M. Żelazny, Heglowska filozofia ducha, Wydawnictwo IFiS PAN, Warszawa 2000; M.J. Siemek, Hegel i filozofia, Oficyna Naukowa, Warszawa 1998; tenże, Idea transcendentalizmu u Fichtego i Kanta. Studium z dziejów filozoficznej problematyki wiedzy, PWN, Warszawa 1977; X. Tilliette, Rescherches sur l'intuition intellectuelle de Kant à Hegel, Librairie Philosophique J. Vrin, Paris 1995; A. Bobko, Kant i Schopenhauer: między racjonalnościa a nicościa, Wydawnictwo Wyższej Szkoły Pedagogicznej, Rzeszów 1996.

${ }^{41}$ Por. AP I, s. 27-32. 
$76 \quad$ Hans Urs von Balthasar wobec idealizmu niemieckiego

całości zostało zdecydowanie zachwiane, a teolodzy luterańscy (jak mówi jeden z nich, cytowany przez Balthasara Paul Althaus) „zgodnie nauczają (...) o całkowitej zagładzie tego świata"42.

Równolegle do rozważań teologów reformacji myśl filozoficzna zmierza do stworzenia idealnego obrazu wiedzy, w którym pojawiłoby się rozumienie absolutnego królestwa prawa, wynikającego niejako bezpośrednio z natury. Ideał abstrakcyjnej ogólności, który swą pełnię osiągnie w racjonalizmie ${ }^{43}$, jest dla Balthasara początkiem pewnego rodzaju zsekularyzowanej eschatologii, w której następuje zbliżenie świata zjawiskowego do wiecznych praw świata boskiego. „Sam zaś świat doczesny rozwija preuformowane w nim wcześniej idee do momentu pokrycia się ich z ideami współistniejącymi w Bogu, a wszystko to w nieprzerwanym szeregu monad od materii do najwyższej świadomości. Dlatego pojęcie nieskończonego zbliżenia się do (abstrakcyjnego) prawzoru stanowi podstawę każdej następującej potem nauki o końcu (Endlehre)"44.

Zbliżenie do abstrakcyjnie pojętego ideału prowadzi do rezygnacji z czasowości i indywidualności ${ }^{45}$. Ostateczną konsekwencją obu światopoglądów, reformacji i oświecenia, jest „stawanie się obojętnym wobec świata zewnętrznego i ciała, ich eschatologiczne wyeliminowanie, a tym samym otwarty spirytualizm"46. $\mathrm{W}$ momencie przejścia od myśli protestanckiej do naukowego

${ }^{42}$ P. Althaus, Die letzten Dinge. Entwurf einer christlichen Eschatologie, C. Bertelsmann, Gütersloh 1922, cyt. za: AP I, s. 27.

43 „»Mos geometricus « jest żądaniem całkowitej zrozumiałości świata aż po osiagnięcie idealnego celu »mathesis universalis «, podobnie jak astronomia dążyła do »formuły świata «"; AP I, s. 28.

44 Tamże, s. 28-29.

45 „Prawo jest jednak ogólne. Szczegół więc, zmierzając ku ogólności, będzie musiał wyzbyć się swojej szczegółowości jako przeszkody”; tamże, s. 29.

46 Tamże, s. 30. 
obrazu świata pojawia się zwątpienie w dowartościowanie osoby oraz zagubienie jej indywidualności i nieśmiertelności ${ }^{47}$. Początek czasów nowożytnych charakteryzuje się natomiast pojawieniem się dążenia do „abstrakcyjnego spirytualizmu”, który w sposób racjonalistyczny zmierza ku przedstawieniu tego, co ostateczne, jako obrazu „prawnej ogólności”48 i ku zachwianiu pojęcia jednostki. Balthasar uważa, że oświecenie niesie ze sobą pełne sprzeczności stwierdzenie, iż „rozum, ponieważ zdaje się odwracać swoje rozważanie od tego, co transcendentne, a zwracać je ku wewnętrznej pełni świata, bardziej bezradnie niż kiedykolwiek przemyka obok wszystkich pojedynczych postaci po to, aby jako zwykłe środki i etapy wstępne pozbawić je nierzeczywistego, nieosiągalnego końca"49.

Balthasar jest przekonany, że odejście rozumu od tego, co transcendentne, prowadzi nieuchronnie do sytuacji, w której zagubione zostaje pragnienie jedności świata, a „absolutne oddalenie od rzeczy ostatecznych łączy się z naiwnym odwracaniem się od nich; bezpośrednia jedność momentu ekstremalnie historycznego (teologicznego) i ekstremalnie niehistorycznego (aksjologicznego) stanowi więc właściwą cechę charakterystyczną eschatologii oświecenia"50. Filozofia Lessinga, Klopstocka i Hamanna, poprzez głębsze spojrzenie na historyczność i egzystencję człowieka, wprowadza i rozwija pojęcie eschatologii egzystencjalnej. Prawdziwe bycie jednostki wynika nie $\mathrm{z}$ analizy świata czystego rozumu jako ucieczki od tego, co zmysłowe i pełne namiętności. Prawda jest przede wszystkim nieskończoną wielością, ,jakościo-

\footnotetext{
${ }^{47}$ Por. tamże.

48 Tamże, s. 31.

49 Tamże, s. 35.

50 Tamże.
} 
wo-barwną szerokością egzystencji" ${ }^{51}$. Dla Herdera tak pojęta egzystencja niesie ze sobą subiektywno-indywidualne ograniczenia. Dlatego też winna być wprowadzona w obszar świata historyczno-empirycznego. Egzystencja jako historia, jak ją pojmował Hamann, jest ,pełnią wszelkiej historycznej egzystencji, ludzkości, »humanitaryzmu «; nie jako abstrakcyjno-prawna, lecz konkretna i dlatego przedstawiająca się nie w wiedzy, lecz w micie"52. Świat jest ,wielostopniową strukturą złożoną z form morfologicznych: niepowtarzalny pojedynczy człowiek, niepowtarzalny naród, niepowtarzalny krąg kulturowy - postacie, które wznoszą się jedna w drugiej i jedna ponad drugą, nie przenosząc przy tym niższej w sferę abstrakcji" ${ }^{53}$. Człowiek w filozofii Herdera nie jest tylko częścią natury, ale stanowi moment pośredni pomiędzy dwoma wzajemnie przenikającymi się systemami natury. Jego zadaniem jest wyrwać się ze swojego ziemskiego bycia, by wspiąć się ku innemu, duchowemu istnieniu ${ }^{54}$. Owo „wyrwanie” rozumiane jest wprawdzie raczej jako przemiana duszy, ale jednocześnie jako jej ruch ku Bogu. Cała historia jej kształtowania „wskazuje poza samą siebie na obraz Boży, który od dawna leży zaciemniony w otchłani duszy" 55 . Człowiek uczestniczy w podwójnym procesie stawania się: historycznym, w którym pojawia się tendencja określenia wewnętrznej podstawy siły rozwojowej, posługującej się pewną postacią, oraz eschatologicznym, otwartym na świat istniejący poza człowiekiem. Poprzez ideę stawania się uczestni-

51 Tamże, s. 56. „Jedynie w owej »nieczystości« nierozerwalnej całości człowieka, złożonej ze zmysłowości i duchowości, jest on sam obrazem najwyższej egzystencji”; tamże, s. 56-57.

52 Tamże, s. 63.

53 Tamże.

${ }^{54}$ Por. J.G. Herder, Myśli o filozofii dziejów, t. I -II, tłum. J. Gałecki, wstęp i komentarz E. Adler, PWN, Warszawa 1962, s. 216-230.

${ }^{55}$ AP I, s. 70. 


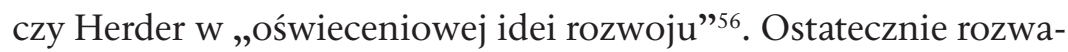
żania Balthasara nad myślą Herdera zmierzają do opracowania religijnego programu odnowy, w którym cechą charakterystyczną jest ożywienie apokaliptyki biblijnej i uświadomienie początku historii ludzkości w nawiązaniu do historii żydowskiej.

\section{Tragiczny dualizm. Immanuel Kant}

Racjonalistyczne oświecenie, zdaniem Balthasara, z jednej strony pokazało pewną ciągłość myśli chrześcijańskiej, z drugiej zaś podjęło próbę jej rozbicia. Po analizie stanowiska Herdera w Balthasarowskich rozważaniach przychodzi czas na myśl Kanta, który w przeciwieństwie do Herdera akcentuje przewagę formy stawania się. Myślący podmiot nie osiągnął jeszcze formy doskonałej. Według Balthasara Kant, największy krytyk i przeciwnik Herdera, jest świadomy faktu, że stosując Herderowski analogon stopniowania form, można dojść jedynie do wniosku, iż gdzie indziej (choćby na innej planecie) mogą istnieć stworzenia zajmujące stopień o jeden wyższy od człowieka, ale nie można na jego podstawie wywnioskować, że ów wyższy poziom osiąga to samo indywiduum $^{57}$.

Podczas gdy dla Herdera granice określające poszczególne istoty pochodzą z zewnątrz, w filozofii Kanta człowiek jako byt duchowy ,posiada swoją istotę z samego siebie i tak też wyznacza sobie "granicę", jako wewnętrzna indywidualność, wyjątkowość, świat wewnętrzny tworzący krąg" ${ }^{58}$. Duch dzięki refleksji nad samym sobą pojmuje te granice jako możliwe warunki własnego istnienia. W ten sposób Kant, zdaniem Balthasara, zmierza do

\footnotetext{
56 Tamże, s. 67.

${ }^{57}$ Por. tamże, s. 91.

58 Tamże, s. 92.
} 
określenia nowej możliwości zaistnienia eschatologii. „Przez to, że duch jednocześnie widzi samego siebie w swej wewnętrznie rozgraniczonej istocie (...) i ową rozgraniczoność pojmuje jako warunek własnej możliwości bycia duchem, odsłania się przed nim nowa możliwość eschatologii. Jego rzeczami ostatecznymi nie są już (w sposób naturalny) Bóg i świat, lecz warunki jego (skończonego) bycia duchem: w miejsce eschatologii »metafizycznej « wkracza »transcendentalna «. Tym samym »apokalipsa duszy « otrzymuje niejako nowy wymiar, z którego wysokości może dokonać się samourzeczywistnienie" ${ }^{59}$. Ostatecznymi rzeczami człowieka nie są już Bóg i sprawy doczesne, lecz warunki skończonego bycia człowieka, bycia podmiotem (duchem).

Nie ulega wątpliwości, że Balthasar chce w idealizmie niemieckim dostrzec pewien zmysł religijny. Jednakże religijność ta przybiera nową formę, w której uwaga skierowana jest przede wszystkim na człowieka i jego historię. To zwrócenie uwagi na człowieka i historię odwraca jakby perspektywę dotychczasowego rozumienia religijności. Podstawowe wartości religii nie są już rozważane $\mathrm{w}$ perspektywie tego, co absolutne i nieskończone, a jedynie w związku z człowiekiem i jego uwarunkowaniami, takimi przede wszystkim, jak czas i przestrzeń.

Kantowskie odwrócenie perspektywy Balthasar kreśli zatem jako przejście z eschatologii metafizycznej do eschatologii transcendentalnej. Kant, jeden z głównych przedstawicieli filozofii transcendentalnej, pozostaje bez wątpienia przy skończoności ducha ludzkiego i ma świadomość, że doświadczanie jej stanowi punkt wyjścia dla namysłu człowieka nad rzeczywistością. Z drugiej strony, to doświadczenie skończoności otwiera nową perspektywę myślenia, w której, według królewieckiego filozofa, człowiek jako podmiot podlega nieustannemu procesowi sta-

\footnotetext{
${ }^{59}$ AP I, s. 92.
} 
wania się. Owszem, wychodząc od świadomości skończoności, Kant buduje refleksję najpierw na temat danych doświadczenia. Jednocześnie zdaje sobie sprawę, że są one jakby prowokacją do tego, żeby podmiot mógł je nieustannie transcendować, ponieważ taka jest natura samego rozumu.

Przedmiotem nowej eschatologii jest transcendentalna jedność apercepcji. Człowiek jako duchowy posiadacz samego siebie urzeczywistnia się tylko jako szczyt wielości, różnorodności ${ }^{60}$. „Ten ostateczny punkt, który sam się nie jawi, a jednak jest źródłem i celem całego systemu, nazywa Kant dlatego »celem samym w sobie«, »świętością«, "podniosłym majestatem «. Jest on wiecznym "punktem zbiegu «, do którego nigdy nie dotrze nic, co doczesne, bo stanowi on radykalny tamten świat, właściwy »koniec wszystkich rzeczy «"61. Transcendentalna jedność kantowska nie może stać się przedmiotem poznania, bo nie ma możliwości refleksji nad samą sobą, pozostaje zatem momentem jedynie określającym, ale niemożliwym do określenia. Jest możliwością w sposób wolny określającą granice, ale nie jest w stanie ograniczyć samej siebie. W myśli Kantowskiej intelekt jawi się jako duch pochłonięty bez reszty syntetyzowaniem doświadczenia, duch, który „widzi siebie w zwierciadle natury i tylko w nim. Jednak owo »ku sobie «, w którym duch poznaje i krytykuje sam siebie jako skończony, wskazuje na pewną podstawę jedności, z punktu widzenia której taka krytyka i poznanie są możliwe, a którą jest nieskończoność rozumu. Owa jedność nie staje się przedmiotowa, ponieważ nie posiada zwierciadła, aby się w nim przejrzeć" ${ }^{2}$.

60 „Pierwszym wytyczeniem wewnętrznej granicy jest zatem uznanie, że duchowe samoposiadanie urzeczywistnia się wyłącznie jako najwyższy szczyt (jedność apercepcji) pewnej różnorodności, która, jako taka, jest nie-duchem"; tamże, s. 93.

${ }^{61}$ Tamże, s. 94.

62 Tamże. 
Balthasar ma wątpliwości, czy takie nastawienie nie ogranicza możliwości dyskusji o tym, co absolutnie transcendentne, bowiem patrzenie na podstawowe wartości i pojęcia religijne staje się w ten sposób możliwe jedynie w analizie podmiotu transcendentalnego. Innymi słowy, mówienie o Bogu jest możliwe tylko $\mathrm{w}$ perspektywie realizacji transcendentalnych potrzeb podmiotu. Dla Balthasara transcendentalna metoda Kanta może prowadzić do wypaczenia perspektywy religijnej. Jeśli bowiem obszar refleksji podmiotu ogranicza się do możliwości transcendentalnych jego samego, to co wówczas dzieje się z takimi kwestiami, jak na przykład uczestnictwo podmiotu w Absolucie, czy też rozumienie przyszłości i realizacja podmiotu w jego perspektywie absolutnej? Czy w takim rozumieniu to, co absolutne, nie stanie się jedynie normą wypracowaną tylko przez samego człowieka, albo też to on i jego historia będą ostateczną zasadą, na mocy której to, co absolutne, stanie się w ogóle zrozumiałe?

Kant zdaje sobie sprawę, że intelekt człowieka ma zdolność poznania syntetycznego, jednoczącego. Podstawą działalności jednoczącej jest dla filozofa wewnętrzna zasada jedności podmiotu, której nie da się sprowadzić do prostej relacji oznaczeń przedmiot-podmiot. W ten sposób trudno też sprowadzić tę zasadę do jakiegoś przedmiotu. Nie jest ona przedmiotem jak wszystkie. Jeśli chciałoby się zredukować ją do przedmiotu, to musiałaby przyjąć postać pewnego elementu transcendentnego, a to mogłoby prowadzić do zredukowania jej do obrazu jakiegoś Absolutu. Spowodowałoby to jednak pewne ograniczenia aktywności samego podmiotu. W związku z tym Kant, według Balthasara, proponuje następujące rozwiązanie: Absolut winien być postrzegany jako dynamiczna wolność w stawaniu się, wolność analogiczna do wolności myśli ludzkiej. Balthasar napisze, że Absolut jawi się jako rzecz sama w sobie, jako punkt ostateczny, ,punkt wiecznej 
ucieczki, którego wszystko, co doczesne, nigdy nie osiągnie, ponieważ wobec owej doczesności stanowi on radykalny »tamten świat «, właściwy »koniec wszelkich rzeczy «"63.

Tajemnicze spotkanie tego, co transcendentne i absolutne, z tym, co immanentne, stanowiłoby dla czystego rozumu pewnego rodzaju cios. Ponieważ dla Kanta wszystko skupia się wokół człowieka, to także od niego zależy wszelka stwórcza myśl, która wznosi się ponad rzeczy. Kant wyraźnie uznaje wyższość zdolności twórczej podmiotu ludzkiego nad rzeczywistością przedmiotową. Inaczej musiałby niejako przyjąć posłuszeństwo tego, co transcendentne, w stosunku do podmiotu. Próba dotarcia do tego, co transcendentne, otworzy się dopiero na płaszczyźnie etycznej, w krytyce praktycznego rozumu. Tam człowiek kantowski będzie posłuszny własnemu prawu wewnętrznemu, i to o wiele bardziej niż transcendentnemu Absolutowi. Doświadczenie Boga zostanie ponownie ukryte w dynamizmie autonomicznego podmiotu, poszukującego swego dopełnienia i swojej przyszłości. „Człowieka bowiem przenika moc, która nigdy nie może stać się dla niego przedmiotowa, która jednak rozsadza go i relatywizuje w tym, co właściwe jego naturze. (...) Świadomość moralna odsłania mu ponadto - co prawda nie tyle przedmiotowy charakter absolutnego, w stosunku do niego ekscentrycznego centrum, co jego absolutny postulat uznania, któremu należy bez reszty podporządkować wszelką wartość właściwą naturze" ${ }^{64}$.

Jedno jest pewne: wezwania wymogu absolutnego należy bezwarunkowo przestrzegać. Problematyczna pozostaje jedynie natura owego wymogu. Sam Kant, by go opisać, sięga bowiem po kategorie tradycji chrześcijańskiej. Imperatyw może przypominać majestat samego Boga, który jednocześnie pobudza do właściwe-

\footnotetext{
63 Tamże.

${ }^{64}$ Tamże, s. 98.
} 
go działania, napełnia uwielbieniem i lękiem. Pozostaje jednak niedostępny w swej wzniosłości i suwerenności. W każdym razie trzeba powiedzieć, że podobnie jak filozofia transcendentalna stawała się refleksją nad możnością samego podmiotu, tak też cała etyka nabiera skłonności do ukazania aktu moralnego opartego ostatecznie także na podmiocie. W ten sposób Kant, wierny filozofii transcendentalnej, podłoża etyki nie może znaleźć nigdzie indziej, tylko w autonomii ludzkiego podmiotu. Podmiot ludzki ma naturę w swojej wolności, która transcenduje wszelką przypadkowość empiryczną. Życie moralne to ciągłe wyzwanie, ponieważ wolność ludzka jest w rzeczywistości także dynamiczna. Podmiot wierny swemu wewnętrznemu nakazowi ciągle zmierza do przodu, by korzystać najpełniej ze swojej wolności. Jednak według Balthasara pojawia się w tym miejscu pewien paradoks, o charakterze egzystencjalnym, polegający na tym, że „eschaton człowieka ukazuje się z jednej strony jako absolutna wolność samookreślenia, z drugiej jako absolutne i niedościgłe prawo, panujące nad istnieniem. Inaczej mówiąc: autoprawodawstwo, które byłoby dopełnione wtedy, gdyby »Ja « (jako totalność homo phenomenon i noumenon) pokrywało się z prawem, jest pojęciem granicznym" 65 .

Niewątpliwie to właśnie Kant reprezentuje podstawowe myśli oświeceniowe i stoi niejako w punkcie zwrotnym. Jest on bowiem radykalnym przedstawicielem myślenia o charakterze immanentnym i jednoznacznym przykładem tragicznego dualizmu: „Kantowski obraz człowieka okazuje się więc tajemnicą w tragicznym dualizmie. W człowieku bowiem tkwi siła, która nigdy nie może stać się dla niego realna, a która jednak rozsadza i relatywizuje to, co w nim naturalne" ${ }^{\circ 6}$.

\footnotetext{
65 Tamże, s. 99.

66 Tamże, s. 98.
} 
Kant pojawia się zatem jako biegun przeciwny do Herdera, ale jednocześnie stanowi ważny punkt odniesienia dla myśli średniowiecznej, w której, przypomnijmy, królowały jedność i harmonia natury i człowieka. W ten sposób idealizm zaczyna jawić się jako pewien zwrot wstecz, a jednocześnie postępując do przodu, wraz z Kantem, wskazuje ponownie na wartość jedności świata widzianego w perspektywie neoplatońskiej. Idealizm niemiecki powinien, według Balthasara, odnaleźć na nowo prawdziwe źródło swego przeznaczenia. Źródłem tym mógłby być ideał harmonii wywodzący się ze świata chrześcijańskiego (starochrześcijańskiego). W ten sposób Kant staje niejako w punkcie przecinania się dwóch tendencji myślowych. Z jednej strony myśl Kantowska jest dla Balthasara możliwością pojednania świata immanentnego i transcendentnego, z drugiej zaś stanowi oddalenie się od źródła prawdziwej transcendencji (niezamkniętej w immanencji).

Balthasar zdaje sobie sprawę, że taki sposób myślenia wpisuje się w Kantowską filozofię stawania się. To podmiot jest źródłem wszelkiego dynamizmu i kreatywności. Przedmiot zaś stanowi jedynie moment, który pozwala podmiotowi realizować wolność działania. W ten sposób kopernikańska rewolucja w myśleniu Kanta polega na tym, że rozumienie świata nie dokonuje się przez wychodzenie od przedmiotowości danego porządku, ale na podstawie wkładu podmiotu, który stopniowo nadaje temu światu sens. Balthasar uważa, że taka rewolucja, owszem, prowadzi Kanta do zrozumienia wewnętrznej dynamiki możliwości podmiotu. Jednak w tej wewnętrznej dynamice podmiotu Balthasar chciałby dostrzec możliwość pewnej zdolności przekraczania tego, co uwarunkowane samą podmiotowością. Z jednej strony, przyglądając się Kantowi, dostrzega on dynamiczną aktywność podmiotu transcendentalnego, która jest w stanie otworzyć przed podmiotem obszar wartości absolutnej, 
$86 \quad$ Hans Urs von Balthasar wobec idealizmu niemieckiego

ale z drugiej strony, ta sama aktywność sama może stać się pewną wartością absolutną.

W dużej mierze ważne jest w tym momencie określenie tego, co Kant rozumie pod pojęciem rzeczywistości absolutnej. Czy rzeczywistość absolutna jest dla ludzkiego podmiotu jedynie aspiracją na drodze stawania się, czy też stanowi rzeczywistość transcendentną, nie do zdobycia dla podmiotu? Konieczność przebadania relacji pomiędzy Absolutem a historią człowieka stanowi dla Balthasara punkt wyjścia Kantowskiej teorii poznania. Nie ulega wątpliwości, że Kant rozważa myśl ludzką w jej radykalnej skończoności. Człowiek jest bytem skończonym, jego refleksja dokonuje się przede wszystkim w czasie i przestrzeni. Zatem bycie $\mathrm{w}$ świecie sprowadza się do pewnego rodzaju organizacji i porządkowania rzeczy, które stają się przedmiotem. Synteza wielości danych zmysłowych dokonywana przez podmiot pozwala na doświadczenie wielości danych. Doświadczenie wielości danych stanowi jednocześnie bodziec do zrozumienia całości rzeczywistości jako pewnej syntezy twórczej. W ten sposób myśl jest otwarta na przyszłość.

Owa synteza danych zmysłowych tworzona przez zdolności podmiotu kreuje bez wątpienia jego twórczą transcendentalność. Ale ta ostatnia, według Balthasara, niesie ze sobą pewne ograniczenia. Owszem, poznanie ludzkiego intelektu stanowi nieustanną wymianę pomiędzy podmiotem a przedmiotem, ale prowadzi jednocześnie do momentu, w którym wymiana ta musi zostać poddana aspiracjom rozumu. Rozum bowiem chce transcendować wszelkie doświadczenie. Myślenie podmiotowe pozostaje zatem zależne od przestrzeni i czasu, wznosząc się jednocześnie ponad tę zależność. W ten sposób człowiek jest z jednej strony duchem w świecie, ale jest także pewnym twórczym dynamizmem, który chce nadawać sens wszystkiemu, co w nim spotyka. Jednak 
owo nadanie sensu musi wychodzić poza ten świat. Problem nadawania sensu światu nie jest typowo kantowski. Balthasara interesuje, jakie są ostatecznie możliwości transcendentalnego podmiotu i jego otwarcia się na świat transcendentny. Możliwości te wskazują jednocześnie na relację między duchem skończonym i nieskończonym.

\subsection{Filozofia praktyczna i moralność}

Według praktycznej filozofii Kantowskiej, człowiek w swej świadomości moralnej zdaje sobie sprawę z transcendentalnej jedności, podobnie jak z prawa moralnego. Niemniej jednak także i tutaj świadomość ta nie ma charakteru przedmiotowego. Poznający podmiot, jak już wcześniej wspomniano, znajduje się w ciągłym napięciu wynikającym z faktu, że to, co ostateczne, jawi się z jednej strony jako absolutna wolność, z drugiej zaś jako absolutne prawo. Człowiek sam z siebie nie jest w stanie zrealizować syntezy świętości jako prawa (rzeczy samej w sobie) i bycia szczęśliwym, wynikającego z działania (sfery zjawiskowej). Wydaje się, że fundamentem takiej syntezy mógłby być Bóg, który jednak w stosunku do człowieka i jego możliwości pozostaje czymś absolutnie zewnętrznym: „Bóg nigdy nie jest syntezą, nigdy nie jest szczęśliwością człowieka, jako punktem, w którym świętość przeradza się dla niego w szczęście. Bóg stwa rza jedynie syntezę, w której ludziom „wszystko idzie zgodnie z ich życzeniem i wolą" ${ }^{67}$. Zewnętrzność Boga w stosunku do człowieka pociąga za sobą stwierdzenie, że ostatecznie to nie „Boża mądrość” jest wewnętrznym światłem jego duszy. Z natury swej rozum ludzki niezdolny jest bowiem do takiego aktu. To „własna iskierka (...) oświeca nas na wieczność" ${ }^{68}$, jako idea Boga w nas.

${ }^{67}$ Tamże, s. 115.

68 Tamże, s. 116. 
Pomiędzy Bogiem, który jako Osoba tworzy syntezę, a tym, co dla człowieka jest święte, nie może powstać relacja, gdyż to nie sam Bóg jako Osoba jest tym, co święte i szczęśliwe. Grzech nie jest naruszeniem czy też zranieniem Boga, lecz jedynie odejściem od prawa ogólnego. Zamiast postawy historyczno-egzystencjalnego spotkania dwóch podmiotów pojawia się stwierdzenie o wyższości prawa nad osobą, w którym najwyższym celem moralnej doskonałości stworzenia jest miłość prawa ${ }^{69}$. Świętość, jako odwieczne przeznaczenie (eschaton), to dla Kanta „uniwersalność tego, co (powszechnie obowiązująco) ogólne, a nie uniwersalność konkretnie istniejącego bytu najwyższego"70. Ostatecznie dla Balthasara pozostaje faktem, że ,apokalipsa duszy, jako jej ostateczna możność bycia całością, w której sens transcendencji duszy (koniec naturalny) wyjaśniałby się sensem wypełnienia osiągniętej transcendencji (koniec nadprzyrodzony) - taka właśnie apokalipsa jest »tajemnicą rozumu «"71.

Z perspektywy kantowskiej Balthasar zadaje pytanie, czy czasem wielkość człowieka jako podmiotu moralnego nie jest przesadna. Człowiek umieszczony w sytuacji pewnego rozdarcia, a mianowicie konieczności nieustannego stawania się i niemożności jego pełnej realizacji, czuje się ogarnięty zwątpieniem. Podmiot, aby pozostać posłusznym prawom swego bytu, musi nieustannie żyć realizacją obowiązku, przymuszającego go do coraz bardziej wzniosłego postępowania. Balthasar zauważa w tym miejscu pewną tragiczność człowieka, który stoi wobec niemożliwości ostatecznego spełnienia ${ }^{72}$.

${ }^{69}$ Por. E. Kant, Religia $w$ obrębie samego rozumu, tłum., wstęp i przypisy A. Bobko, Znak, Kraków 1993, s. 179. Por. także: AP I, s. 117.

${ }^{70}$ AP I, s. 116.

${ }^{71}$ Tamże, s. 98.

72 Por. tamże. 
W obliczu ostatecznego spełnienia kondycja człowieka staje się dość mocno ambiwalentna. Z jednej strony bowiem, człowiek zdaje sobie sprawę z tego, kim jest, z drugiej zaś czuje nieustanny obowiązek doskonalenia siebie, niwecząc w ten sposób dotychczasowe osiągnięcia. Tym samym, w miarę, jak musi się wznosić do spełnienia coraz większych obowiązków, zostaje skonfrontowany z pytaniem o sens nieustannego doskonalenia: czy rzeczywiście imperatyw wewnętrzny jest jednocześnie odpowiedzią na sens wszelkiego działania podmiotu moralnego? Co, tak naprawdę, może on osiągnąć, postępując w ten sposób? Jaki jest kres nieustannego spełniania obowiązków i doskonalenia się? Czy te wysiłki prowadzą do osiągnięcia jakiegoś najwyższego dobra, które byłoby ostatecznym szczęściem człowieka?

Moralno-religijna idea Kanta dotycząca czasów ostatecznych ulega zatem, według Balthasara, fascynacji coraz większym oddalaniem się od źródła prawdziwej transcendencji. Dążenie Kanta do transcendencji wydaje się ruchem daremnym. W związku z tym powstaje tajemniczy paradoks myślowy, który wyobrażenie Boga i nieśmiertelności duszy przekształca w nieprawdziwą, immanentną transcendencję, bądź też widzi je jako niezgłębioną tajemnicę ${ }^{73}$. Przecież z jednej strony Bóg i nieśmiertelność duszy ujmowane są jako postulaty wyprowadzane z ludzkiego prawa i przez to niemające znaczenia transcendentnego, z drugiej zaś zostają przypisane do rzeczy samej w sobie, stając się przez to formami myślowymi, z którymi człowiek jako istota skończona i czasowa nie może nawiązać żadnego kontaktu.

Balthasar zauważa, że kantowskie dążenie do dobra i szczęścia może pozostać jedynie pewnego rodzaju postulatem podmiotu. Może się okazać, że nie zostanie ono nigdy zrealizowane, czyli że podmiot nie będzie nigdy $\mathrm{w}$ posiadaniu doskonałego dobra

${ }^{73}$ Por. tamże, s. 99. 
i szczęścia. Bez wątpienia podmiot kantowski dąży do osiągnięcia pewnego rodzaju syntezy, której zwieńczeniem byłoby osiągnięcie jakiegoś eschatologicznego kresu. Ale, znając zasadnicze założenia myśli Kantowskiej, synteza ta jest jedynie oczekiwaniem, ponieważ jej przedmiot jest ciągle nie do uchwycenia. Pozostaje on bowiem ciągle $\mathrm{w}$ obszarze transcendentnej niedostępności. W związku z tym podmiotowi pozostaje jedynie wyobrazić sobie ostateczne szczęście, które wynurzyć się może z głębi jego samego. W tym miejscu Balthasar wyraża podstawową wątpliwość, czy czasem człowiek kantowski nie uwięzi się w ten sposób w sobie samym, w tym, czego wymaga jego własne spełnienie. Postulat filozofii transcendentalnej Kanta ukazuje jedynie fragment przyszłości, którą człowiek chce osiągnąć dzięki sobie. W ten sposób nie jest w stanie zdystansować się od własnej podmiotowości.

Balthasar dostrzega usiłowania Kanta, by doprowadzić do końca refleksje związane z dokonaniem syntezy możliwości podmiotu i rzeczywistości; syntezy mającej doprowadzić do szczęścia. Refleksje te wydają się zmierzać w kierunku czystego antropocentryzmu. Postawienie człowieka $\mathrm{w}$ ich centrum musi rodzić namysł nad podstawowymi ideami chrześcijańskimi, takimi jak nieśmiertelność czy istnienie Boga. Mówiąc o nieśmiertelności i istnieniu Boga, Kant unika wszelkich stwierdzeń i afirmacji na temat tego, co przedmiotowe (obiektywne). To bowiem, co obiektywne i przedmiotowe, odnosiłoby się do transcendentnej obecności Boga, ale byłoby przeciwne dynamicznej ewolucji stawania się podmiotu moralnego. Takie napięcie relacji w miejscu tego, co podmiotowe i przedmiotowe, Balthasar wyjaśnia w sposób następujący: „Z faktu, że człowiek znajduje się w obowiązku zrobienia czegoś, co dla niego jest niemożliwe do spełnienia, filozofia zostaje jakby przewyższona przez teologię. Nie jest to wszak, jak podkreśla sam Kant, prawdziwa teologia, albowiem rzeczywi- 
stość łaski i syntezy, która się realizuje, nie może mu zostać dana jako przedmiot. W interwencji łaski refleksja podmiotu nie mogłaby przyjąć postawy, w której przyczynek rozumu praktycznego to jedynie tyle, co czysty dynamizm podmiotu ludzkiego, który zmierza ku syntezie" 74 .

Reasumując, człowiek kantowski nie jest w stanie pojąć rzeczywistości Boga, który jest i który udziela mu szczęścia i zbawienia. Kant nie może uznać takiego Boga, ponieważ płynąca od Niego łaska byłaby momentem działającym z zewnątrz, a tym samym przeszkodą dla dynamizmu wolności podmiotu. Wydaje się zatem, że nawet jeśli podmiot kantowski ciągle potrzebuje dopełnienia, przyjęcia czegoś z zewnątrz, to owo dopełnienie zewnętrzne, czymkolwiek by było, musi znaleźć swoje miejsce w pragnieniach i aktach samego podmiotu. Oznacza to, że łaska pochodzacca od Boga transcendentnego jest w stosunku do podmiotu jedynie postulatem rozumu praktycznego; postulatem, który wyznacza sobie sam rozum. Może on stworzyć tylko pewien projekt, nadający sens wszelkiemu zaangażowaniu podmiotowemu. Podmiot kantowski nie interesuje się zatem nieśmiertelnością, ponieważ znajduje się ona poza czasowością. Zamiast tego, według Balthasara, stwarza on sobie sen o nieśmiertelności widzianej jako nieskończony postęp w czasie.

Balthasar zdaje sobie sprawę z Kantowskiego rozróżnienia wiedzy i wiary, które prowadzi ostatecznie do napięcia pomiędzy samowiedzą i moralno-religijną autonomią człowieka z jednej a wiodącą dalej wiarą w Boga $\mathrm{z}$ drugiej strony ${ }^{75}$. Wydaje się, że Kant w swojej moralno-religijnej teorii końca (Endlehre) stworzył

${ }^{74}$ Tamże, s. 104.

75 Por. M. Bondeli, Mystische Potentialität. Hans Urs von Balthasar über den Weg von Kant zu Hegel, w: Letzte Haltungen. Hans Urs von Balthasars „Apokalypse der deutschen Seele” - neu gelesen, hrsg. von B. Hallensleben, G. Vergauwen, Academic Press-Paulusverlag, Freiburg 2006, s. 146. 
perspektywę objawienia i wyobrażenia o czasach ostatecznych, wyobrażenia o „samo-apokalipsie”, które będzie kontynuowane przez Fichtego ${ }^{76}$. Wyobrażenie samo-apokalipsy wyraża stosunek, w którym chciałoby się widzieć jedność tego, co czasowe, i tego, co nieskończone, ale ponieważ Bóg jako rzecz sama w sobie jest niedostępny, nie może mieć z tego stosunku żadnej korzyści. Kantowska idea czasów ostatecznych stoi, według Balthasara, pod znakiem tragicznego dualizmu. Być może użycie w tym miejscu słowa „tragiczność”77 jest pewnego rodzaju nadużyciem, ale nie ulega wątpliwości, że niedostępność Boga dla chrześcijańskiego sposobu patrzenia na rzeczy ostateczne ma znamiona sytuacji pozbawionej nadziei.

Ostatecznie filozofia Kanta wydaje się dla Balthasara przede wszystkim filozofią ludzkiej autonomii. Twierdzenia związane $\mathrm{z}$ istnieniem Boga, doświadczeniem łaski sprowadzane są do punktu, w którym człowiek doświadcza wolności w realizacji samego siebie. Wolność ta polega koniec końców na posłuszeństwie woli podmiotu. W ten sposób, twierdzi Balthasar, Kant wprowa-

${ }^{76}$ Por. tamże, s. 147.

${ }^{77}$ Martin Bondeli uważa wprost odwrotnie. Twierdzi, że w przypadku Kanta można mówić o szczęśliwym dualiście: „Kiedy Kant konstatuje istnienie przepaści między pojęciem a zmysłową naocznością, ponieważ pojęcia w przeciwieństwie do form zmysłowej naoczności, to znaczy przestrzeni i czasu, nie mają nic wspólnego z rozciągłością czy podzielnością, nie oznacza to dla niego nieszczęścia. Tylko dzięki tej przepaści udaje się bowiem, jego zdaniem, zdystansować od realizmu pojęciowego. (...) Podobnie ma się rzecz w przypadku dualizmu jawienia się i rzeczy samej w sobie. Jak argumentuje Kant, tylko dzięki owemu dualizmowi można odróżniać się od form dogmatyzmu (np. od metafizycznego realizmu) oraz od form sceptycyzmu (np. od dogmatycznego subiektywizmu czy relatywizmu). (...) Trudno wreszcie nie zauważyć, że według Kanta również dualizm natury i wolności przy porównaniu problemów wykazuje bilans pozytywny. Dualizm ten pociaga wprawdzie za sobą problemy przekazywania wolności i natury, jest jednak warunkiem koniecznym do tego, aby o wolności moralnej móc myśleć niezależnie od wyobrażeń o konieczności natury" ; tamże. 
dza eschatologię, która nie przekracza granic tego, co czasowe i przestrzenne. Skupienie się na człowieku i jego własnej przyszłości zamyka mu drogę do możliwości rzeczywistego uczestnictwa w pięknie Absolutu. W myśli chrześcijańskiej człowiek nie może uczestniczyć w pięknie absolutnym inaczej, jak tylko przez zdystansowanie się do siebie samego, a nawet całkowite wyrzeczenie się samego siebie. Kantowski dynamizm transcendentalny zmierza jedynie do zapewnienia rozwoju samego podmiotu. Podmiot sam z siebie zdolny jest doskonalić swoje zamierzenia. Transcendentność Boga i Jego łaska mogą być widziane jedynie jako narzędzie w służbie rozwoju ludzkiego podmiotu. 
- 


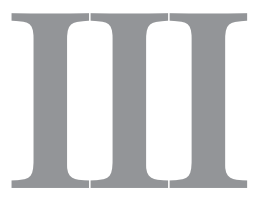

\section{Systemy pokantowskie}

Jeśli przez idealizm niemiecki rozumieć epokę niemieckiej filozofii, która metodę i podstawowe zagadnienia tematyczne czerpie z Kantowskich określeń i spekulacji, to zrozumiałe staje się stwierdzenie, że to właśnie Kantowska koncepcja krytyki rozumu doprowadziła do powstania spekulatywnych systemów Fichtego, Schellinga i Hegla. Systemy te bądź pozostają we wspólnym myśleniu z Kantem, bądź też wyraźnie go krytykują ${ }^{1}$. Wydaje się jed-

${ }^{1}$ Por. Historisches Wörterbuch der Philosophie, hrsg. von J. Ritter, K. Gründer, Bd. 4, Basel-Stuttgart 1976, s. 35-38; N. Hartmann, Die Philosophie des deutschen Idealismus, Berlin-New York 1974³. Mirosław Żelazny zwraca uwagę, że w obrębie idealizmu niemieckiego widzi się przede wszystkim systemy Kanta, Fichtego, Schellinga i Hegla. Tymczasem sam Kant dystansował się od tak przypisywanego mu powinowactwa duchowego. Według Żelaznego, „Jeśli linię filozofii idealistycznej dość konsekwentnie rozwijaną w systemach Fichtego, Schellinga, wreszcie Hegla uznamy rzeczywiście za jakąś formę kontynuacji myśli Kantowskiej, to kontynuacja taka była możliwa tylko na drodze bardzo istotnego zwrotu epistemologicznego, jakiego w stosunku do idealizmu Kantowskiego dokonał właśnie Fichte”; M. Żelazny, Heglowska 
$96 \quad$ Hans Urs von Balthasar wobec idealizmu niemieckiego

nak, że filozofowie ci rozwinęli pewną wspólną myśl - można by ją określić mianem „filozofii ducha” - która znajdzie dopełnienie, a zarazem zwieńczenie w heglizmie.

Miejsce samego Kanta w tym wspólnym myśleniu jest zatem postrzegane różnie. W pojawiających się interpretacjach widać tendencję do stwierdzenia, że to właśnie w Kantowskiej krytyce rozumu może brać początek Heglowska filozofia ducha. Wtedy droga od Kanta do Hegla byłaby pewną formą ciągłości myślenia idealistycznego ${ }^{3}$, czemu jednak przeczy wyraźne dążenie do przezwyciężenia dualizmu oglądu rzeczywistości noumenalnej i fenomenalnej. Ostatecznym wspólnym celem myślicieli idealizmu niemieckiego jest stworzenie rygorystycznego, wszechogarniającego systemu filozoficznego opartego na ostatnich i zarazem pierwszych przyczynach. Sporna wydaje się pozycja Schellinga. Dyskusyjne jest bowiem, czy pozostaje on jedynie poprzednikiem Hegla, czy też winien być widziany jako ten, który dopełnia idealizm niemiecki. Podobnie problematyczne jest stwierdzenie przynależności do idealizmu niemieckiego Schopenhauera i Nietzschego oraz spadkobierców i kontynuatorów Hegla: Feuerbacha, Marksa i Kierkegaarda, którym Balthasar poświęca wiele miejsca w swej twórczości.

Jeśli słuszne jest stwierdzenie, że Kantowska koncepcja krytyki rozumu doprowadziła także do powstania spekulatywnych

filozofia ducha, Wydawnictwo IFiS PAN, Warszawa 2000, s. 22. Por. także: D. Heinrich, Grundlegung aus dem Ich. Untersuchungen zur Vorgeschichte des Idealismus. Tübingen-Jena 1790-1794, Suhrkamp, Frankfurt 2004; L. Siep, Praktische Philosophie im Deutschen Idealismus, Suhrkamp, Frankfurt 1992; R. Lauth, Die Entstehung von Schellings Identitätsphilosophie in der Auseinandersetzung mit Fichtes Wissenschaftslehre: (1795-1801), Alber, Freiburg im Breisgau-München 1975.

${ }^{2}$ Por. CH III/1/2, rozdział 6, zatytułowany Metafizyka ducha.

${ }^{3}$ Por. X. Tilliette, Rescherches sur l'intuition intellectuelle de Kant à Hegel, Librairie Philosophique J. Vrin, Paris 1995. 
systemów Fichtego, Schellinga i Hegla, to zasadne wydaje się dotarcie do tego, w jakiej mierze filozofia tych systemów przeniknęła do myśli Balthasara i jak została przez niego odczytana. Trudno w tym miejscu ukazać całą historię zdarzeń związanych z kontekstem społecznym i kulturowym, w których pojawiły się reakcje na filozofię Kanta, dlatego wystarczające dla niniejszej pracy będzie wskazanie jedynie głównych źródeł historycznych i oddziaływań nawiązujących do analiz Kantowskich koncepcji rozumu.

\section{Myślenie systemowe}

Próby udoskonalenia i szerzenia systemu myślowego Kanta zostały podjęte przede wszystkim przez Karla Leonharda Reinholda jego wiernego ucznia i interpretatora, który do Kantowskiego myślenia filozoficznego ponownie wprowadził intuicję intelektualną. Jego zamierzeniem było ukazanie całościowego systemu Kanta, obejmującego zarówno rozum teoretyczny, jak i praktyczny. Zdając sobie sprawę ze słabości transcendentalnej zasady unifikującej myślenie teoretyczne na płaszczyźnie dedukcji pojęć, Reinhold był przekonany, że świadomość stanowi element pośredniczący w unifikacji Kantowskiej teorii poznania, a fundamentalna kategoria transcendentalna ,ja myślę” jest za słaba, by

${ }^{4}$ Zob. na ten temat: K.L. Reinhold, Versuch einer neuen Theorie des menschlichen Vorstellungsvermögens, 1789, hrsg. von E.-O. Onnasch, 1. Teilband, Felix Meiner Verlag, Hamburg 2010; K.L. Reinhold, Gesammelte Schriften, Kommentierte Ausgabe, hrsg. von M. Bondeli, Schwabe-Verlag, Basel 2007 nn. Por. także: M. Bondeli, Das Anfangsproblem bei Karl Leonhard Reinhold. Eine systematische und entwicklungsgeschichtliche Untersuchung zur Philosophie Reinholds in der Zeit von 1789 bis 1803, V. Klostermann, Frankfurt am Main 1995; A.J. Noras, Kant a neokantyzm badeński i marburski, Wydawnictwo Uniwersytetu Śląskiego, Katowice 2005; N. Hartmann, Die Philosophie des deutschen Idealismus, dz. cyt. (na temat filozofii K.L. Reinholda s. 8-15). 
sama była zdolna dokonywać syntezy tego, co różnorodne ${ }^{5}$. Poza tym uważa, że rzecz sama w sobie jest niedostępna i nie da się jej w żaden sposób przedstawić. Podmiot przedstawiający nie jest intuicyjnie bezpośrednio widziany jako przedmiot świadomości, lecz ukazuje się jedynie w swoim przedstawieniu, jest naturalną tajemnicą. Jedyna droga do niego prowadzi przez przedstawienie, jako kluczowe pojęcie poznania rzeczy samej w sobie. W ten sposób Reinhold zamierzał wzmocnić rozważania teoretyczne Kanta sferą świadomości, z jednej strony otwierając w ten sposób pole do dyskusji dla sceptyków Kantowskiej myśli, a z drugiej dał impuls do powstania systemu teorii wiedzy Fichtego.

Odrzucenie świadomości jako propozycji wzmocnienia transcendentalnej metody dowodzenia doprowadziło do zdecydowanej reakcji ze strony Fichtego, wskazującego na możliwość kontynuacji myślenia Kantowskiego w duchu uzupełnień zaproponowanych przez Reinholda. Dla Fichtego najwyższą zasadą, na której można zbudować jednolity system, jest ustanawiające samo siebie Ja, lub samoświadomość. „Ustanowione Ja przez siebie samo jest więc jego czystą aktywnością. Ja samo siebie ustanawia, i jest - na mocy tego li tylko ustanawiania siebie przez siebie samo. Jak też odwrotnie: Ja jest, i ustanawia swój byt, na mocy samego li tylko bycia"'. W ten sposób cały system zostaje wyniesiony na wyższy poziom, a myśl Kantowska uratowana od ułomności i niedociągnięć. Droga do pierwszych projektów Schellinga i Hegla została zatem otwarta. Zarówno teoria wiedzy Fichtego, jak też filozofia przyrody Schellinga i metafizyczna budowla wiedzy absolutnej Hegla jawią się jako wyniki udoskonalenia Reinholdowskiej idei całościowego systemu

${ }^{5}$ Por. X. Tilliette, Rescherches sur l'intuition intellectuelle de Kant à Hegel, dz. cyt., s. 39-52.

${ }^{6}$ J.G. Fichte, Teoria wiedzy. Wybór pism, t. 1, wybór, tłum., wstęp i przypisy M.J. Siemek, aneks tłum. J. Garewicz, PWN, Warszawa 1996, s. 89. 
rozumu. Wydaje się, iż wszyscy trzej stanowią przykład przekonania, że ich własny system stanowi dopełnienie wielu pokrewnych postaci podobnego myślenia, w którym otwarty, filozofujący rozum po przejściu przez krytykę kantowską dochodzi do systemów Fichtego i Schellinga, by ostatecznie dotrzeć do siebie w filozofii Hegla.

\section{Struktura idealizmu pokantowskiego}

Zasadniczym problemem stanowiącym wyraźne tło historyczno-metodologiczne rozważań Balthasara jest pytanie: jak dalece systemy pokantowskie tworzą lepsze formy filozofii, przewyższające Kantowską krytykę rozumu? Większość interpretatorów idealizmu niemieckiego ukazywała sposób pojmowania rozwoju myśli od Kanta do systemów pokantowskich i widziała w nim moment przejściowy w drodze do filozofii Hegla. Pośród wielu takich interpretacji z początku XX wieku można wymienić zarówno Historię idealizmu niemieckiego Moritza Kronenberga ${ }^{7}$, jak też dzieło Richarda Kronera Od Kanta po Hegla ${ }^{8}$. Według Martina Bondeliego, w obydwu dziełach systemy pokantowskie widziane są jako elementy jednolitego sposobu myślenia, ukazującego związki i napięcia dotyczące przekazywania zasad subiektywnego i obiektywnego ujmowania rzeczywistości i podmiotowego wi-

${ }^{7}$ M. Kronenberg, Geschichte des deutschen Idealismus, Bd. 1: Die idealistische Ideen-Entwicklung von ihren Anfängen bis Kant, Oskar Beck, München 1909; Bd. 2: Die Blütezeit des deutschen Idealismus. Von Kant bis Hegel, Oskar Beck, München 1912.

${ }^{8}$ R. Kroner, Von Kant bis Hegel, Bd. 1: Von der Vernunftkritik zur Naturphilosophie, Mohr, Tübingen 1921; Bd. 2: Von der Naturphilosophie zur Philosophie des Geistes, Mohr, Tübingen 1924, $1961^{2}$. 
dzenia świata ${ }^{9}$. Droga od Kanta do Hegla świadczy bez wątpienia o świadomości znaczenia samej filozofii Heglowskiej. Hegel jawi się nie tylko jako kres owej drogi, ale wskazuje także na pewną dojrzałość i wznoszenie się myśli spekulatywnej ku coraz pełniejszemu przezwyciężeniu niedoskonałości kantowskich.

W latach 1923 i 1929 Nicolai Hartmann publikuje Filozofię idealizmu niemieckiego ${ }^{10}$ : dwa tomy poświęcone analizie metody transcendentalnej i jej przemianie w dialektyczne widzenie rzeczywistości, szkicując drogę od Kanta do Hegla ,jako świadomość, która w kwestiach metod oraz przekazywania idealizmu i realizmu rozwija się na wyższy poziom" ${ }^{11}$. W lepsze rozumienie przestrzeni myślowej między Kantem i Heglem wpisują się bez wątpienia książka Martina Heideggera Kant a problem metafi$z y k i^{12}$ oraz jego wykłady o idealizmie niemieckim z 1929 roku. Heideggerowskie spojrzenie na filozofię Kanta, Fichtego, Schellinga i Hegla to próba odpowiedzi na podstawowe pytanie o bycie bytu i nowe spojrzenie na metafizykę. Wydaje się, że z jednej strony wspólnym mianownikiem wszystkich tych opracowań było zamiłowanie do filozofii Heglowskiej, któremu uległ także sam Balthasar; z drugiej zaś, motywacją do namysłu nad nią była

9 Por. M. Bondeli, Mystische Potentialität. Hans Urs von Balthasar über den Weg von Kant zu Hegel, w: Letzte Haltungen. Hans Urs von Balthasars „Apokalypse der deutschen Seele” - neu gelesen, hrsg. von B. Hallensleben, G. Vergauwen, Academic Press-Paulusverlag, Freiburg 2006, s. 136-137.

${ }^{10}$ N. Hartmann, Die Philosophie des deutschen Idealismus, 1. Teil: Fichte, Schelling und die Romantik, de Gruyter, Berlin-Leipzig 1923; 2. Teil: Hegel, de Gruyter, Berlin-Leipzig 1929.

${ }^{11}$ M. Bondeli, Mystische Potentialität, dz. cyt., s. 137.

${ }_{12}$ M. Heidegger, Kant und das Problem der Metaphysik, Klostermann, Frankfurt am Main 1929 (wyd. pol.: M. Heidegger, Kant a problem metafizyki, tłum. B. Baran, PWN, Warszawa 1989); tenże, Der deutsche Idealismus (Fichte, Schelling, Hegel) und die philosophische Problemlage der Gegenwart, Gesamtausgabe, II. Abteilung: Vorlesungen 1919-1944, Bd. 28, Klostermann, Frankfurt am Main 1997. 
rywalizacja z neokantyzmem, reprezentowanym przede wszystkim przez Ernsta Cassierera ${ }^{13}$, zwalczającego dominację Hegla nad systemami pokantowskimi. W przestrzeń historyczną wielkich dwudziestowiecznych interpretacji idealizmu niemieckiego wpisuje się bez wątpienia także myśl Balthasara, który ukazuje go z chrześcijańskiego punktu widzenia.

\section{Mit Prometeusza}

Przypomnijmy, że począwszy od Kanta, idealizm niemiecki musi dokonać niejako historycznego zwrotu wstecz, by dotrzeć do pierwotnego ideału harmonii, istniejącego według Balthasara w świecie starochrześcijańskim, w którym indywidualna eschatologia ludzkości i natury były ze sobą nierozerwalnie złączone. Dlatego też zrozumiały wydaje się Balthasarowski zamiar ponownego skierowania myśli do świata mitu, który będąc niejako środkiem pomiędzy czystym pojęciem a czystym oglądem, stanowi perspektywę całościowego ujęcia rzeczywistości.

Świat idealizmu niemieckiego przedstawia Balthasar jako mit Prometeusza, pod którego postacią Goethe wyraża „twórczą negację, stanowiącą dynamiczny środek świata między »Hen« a »Pan «"14. Obraz Prometeusza wydaje się kontynuacją idealistycznych zarysów myśli Kantowskiej. Filozofia Fichtego, Schellinga i Hegla staje się próbą dedukcyjnego dojścia do całości bycia. W centrum systemu znajduje się transcendentalny pod-

${ }^{13}$ Por. E. Cassirer, Das Erkenntnisproblem in der Philosophie und Wissenschaft der neueren Zeit, Bd. 3: Die nachkantischen Systeme, Wissenschaftliche Buchgesellschaft, Darmstadt 1974 (reprint wyd. II z 1923 roku).

${ }^{14}$ AP I, s. 147. Zasadnicze rozważania na temat idealizmu zatytułował Balthasar Prometheus Prinzip; por. tamże, s. 139, oraz: H.U. von Balthasar, Teodramatyka, t. I: Prolegomena, tłum. M. Mijalska, M. Rodkiewicz, W. Szymona, Wydawnictwo M, Kraków 2005, s. 524. 
miot kantowski. Transcendentalna jedność, jawiąca się u Kanta jako homo noumenon i będąca „niejednoznacznością pomiędzy immanentną boskością i współudziałem w transcendentnej autonomii Bożej"15, zostaje przebóstwiona w idealistycznym spojrzeniu na całość rzeczywistości, która w sposób wyraźny rozwinie się w myśli Fichtego. Jedność ta przestaje być już jedynie kategorią antropologiczną, przeradza się w punkt przecinania się całej rzeczywistości. Człowiek staje się środkiem między Bogiem i światem, a jednocześnie reprezentantem takiej postawy wobec rzeczy ostatecznych, która „traktowała siebie jako chwalebny i jednocześnie znieczulający punkt pośredni pomiędzy Bogiem i światem: jako pośrednika między boskim »wszystko « a światowym »nic « oraz między światowym »wszystko « a boskim »nic «, i w tym podwójnym $\delta \iota \alpha$ postrzegała siebie jako sławę i ból dialektyki" ${ }^{16}$. W ten sposób człowiek jest realizatorem podwójnego ruchu: „Wraz ze światem zawsze jako całość skierowany jest ku Bogu, z Bogiem zaś zawsze jako całość - ku światu"17. Wewnątrz samego siebie czuje się zatem zdeterminowany poprzez podwójne $\delta \iota \alpha$. Z jednej strony, odczuwa pragnienie, które popycha go ku naturze, z drugiej zaś rozrywa go tęsknota ducha. A jednak „owo podwójne $\delta \iota \alpha$, niwelujące wszelkie przepaści, jest prawem człowieka, strukturą ekscentrycznie scentrowanego bytu, i to właśnie $\mathrm{w}$ jego najwyższym, ostatecznym sensie, jest więc prawem pełnej apokalipsy duszy"18. Dusza, będąca punktem przecięcia dynamiki świata zmierzającego ku Bogu i Boga skłaniającego się ku światu, nie może zrealizować swego zadnia, nie jest w stanie osiągnąć jednocześnie tych dwóch rzeczywistości.

\footnotetext{
${ }^{15}$ AP I, s. 118.

16 Tamże, s. 5.

17 Tamże, s. 142.

18 Tamże, s. 143.
} 
Taka dialektyka jest prawem człowieka i warunkiem istnienia Boga, który ostatecznie jawi się jako iskierka duszy, rozniecona po to, aby stać się byciem całości ${ }^{19}$. Bóg przestaje być postrzegany jako wolny Stwórca ponad światem, jest ,absolutny tylko w całości tego, co względne, jest wieczny przez czas, niezależny przez to, co zależne" ${ }^{20}$. Bóg staje się dopiero w zaistnieniu zdarzenia podwójnego $\delta \iota \alpha$. W ten sposób człowiek ma jednocześnie udział w stwarzaniu i w działaniu bycia oraz w stawaniu się świata i Boga, nie tylko dlatego, że On obdarzył go taką zdolnością, lecz dlatego, że wydaje się ona koniecznością samego Boga. Człowiek jest prometejskim, twórczym środkiem całej rzeczywistości i poprzez samorealizację pozostaje skierowany na Boga. $\mathrm{W}$ ten sposób pojawia się przed nim nowy cel, który „wykracza daleko poza wszelkie »myślenie« i »chcenie «, cel mistyczny"21. Człowiek otrzymuje zadanie bycia pośrednikiem między Bogiem i światem, a w nim jedynym, absolutnym mediatorem procesu dialektycznego. Zadaniem jego jest „rozszerzać się w całość świata i ową całość przyprowadzić ponownie do Boga, (...) prawo serca staje się prawem wszechświata" ${ }^{22}$. Konkretne doświadczenie tej dialektyki jest naznaczone cierpieniem. Balthasar zwie ją „dialektyką serca"23. Serce bowiem rozdarte jest przez dwa zwalczające się i wykluczające nawzajem ruchy. Człowiek realizuje się w ten sposób jedynie kosztem walki. Tym samym pojawia się „kreatyw-

\footnotetext{
${ }^{19}$ Por. tamże.

20 Tamże.

${ }^{21}$ Tamże.

22 Tamże, s. 144.

${ }^{23}$ Tamże, s. 143. „To, co powiedziano tutaj z pewnym chłodem i dystansem, dotyczy w pełni tego, co najbardziej żywotne w idealizmie: jest on dialektyką serca, ponieważ jest dialektyką człowieka w jego egzystencji i przez to właśnie »mistyką«, jednak »nowszą « w stosunku do chrześcijańskiej”;
} tamże, s. 144. 
na negacja" ${ }^{24}$. Z niej dedukuje się prawo, według którego światło pojawia się jedynie poprzez ciemności, a miłość poprzez poczucie winy. U przedstawicieli idealizmu Balthasar poszukuje egzystencjalnego rozwiązania dialektyki serca. Wydaje się, że wysiłek poszczególnych autorów zmierza do ukazania absolutnej różnicy pomiędzy Bogiem a światem. Balthasar proponuje wyraźnie konfrontację wizji egzystencjalnej z ujęciem chrześcijańskim. Różnica pomiędzy tymi dwiema wizjami wyraża się w odmiennych koncepcjach mistyki i tragiczności. Idealizm proponuje i rozważa ruch mistyczny wewnątrz dialektyki; ruch konieczny, mający charakter jednocześnie regresywny i progresywny. Poszukuje zatem różnicy pomiędzy dwoma biegunami dialektycznymi. Wizja chrześcijańska, charakteryzująca się jednym ruchem, zmierzającym ponownie ku Bogu, rozważa tę różnicę jako element powrotu miłości, która transcenduje ku Niemu ${ }^{25}$.

Ogień Prometeusza płonie zatem pomiędzy byciem a nicością i kieruje się ku zniszczeniu wszelkiej indywidualności. Prometejski myśliciel staje pośrodku jako człowiek, będący jednocześnie podwójnym przejściem do ducha i natury. Wyraża w sobie dwukierunkowy ruch: natury ku Bogu, ku absolutnej postawie człowieka, oraz ducha ku naturze, ku absolutnej postawie działania. By móc rozwiązać i zrealizować myśl w duchu prometejskim, filozofia staje się wyraźnie idealistyczna, zmierza w kierunku immanentnego zdobycia przestrzeni tego, co istotne. Jednakże tam, gdzie prometejski sposób myślenia stawia siebie w samym centrum, jego prawo działania staje się prawem całej rzeczywistości. Tutaj pojawia się pierwotna tragedia idealistycznej, dialektycznej mistyki, unoszącej się pomiędzy tzw. postawą poświęcenia siebie

${ }^{24}$ Tamże.

25 Por. M. Jöhri, Descensus Dei: Teologia della croce nell' opera di Hans Urs von Balthasar, Libreria Editrice della Pontificia Univ. Lateranense, Roma 1981, s. 108, oraz AP I, s. 157. 
a postawą czynu ${ }^{26}$. To bycie „pomiędzy” staje się niemożliwe do zrealizowania. Dialektyka wpływa na świat, w którym człowiek staje się nierozwiązywalnym paradoksem jedności pełni i niezrealizowania bycia ${ }^{27}$. Człowiek bowiem poprzez dialektykę prometejską uwikłany jest w sprzeczność absolutu i ograniczoności. Ostatecznie przecież nie może stać się Prometeuszem i nie jest w stanie rozwikłać dialektycznej sprzeczności. Idealizm niemiecki, zdaniem Balthasara, wydobywa na zewnątrz negatywną stronę Prometeusza ${ }^{28}$.

\section{Mistyczna potencjalność}

Zrozumiały staje się fakt, że w Apokalypse der deutschen Seele Balthasar interpretuje idealizm niemiecki w relacji do mitologicznych form rozumienia świata. Analizuje widzenie ostatecznych czasów i postaw w świecie idei Kanta, Schillera, Fichtego, Schellinga, Novalisa, Hölderlina, Goethego, Jeana Paula i Hegla, wychodząc od losów postaci mitologicznych, Chrystusa, Sokratesa, Prometeusza, Empedoklesa, Fausta, Apollona i Dionizosa.

${ }^{26}$ „Przez to, że ruch natury ku Bogu dopełnia się w człowieku, przez to, iż staje się on całkowicie otwierającym się, poświęcającym się i przyjmującym zwierciadłem pra-ognia, jest on absolutem na granicy postawy poświęcenia siebie. Przez to jednak, że człowiek, wywodząc swoje działanie z centrum Bożego, oddziałuje na świat dopóty, dopóki nawet najbardziej peryferyjny czyn nie przemieni jego wewnętrznego ognia w największy blask, jest absolutem na granicy swojej postawy czynu"; AP I, s. 144.

27 ,Świat bowiem, co było wiadomo już w micie Lucyfera, jest niczym innym niż dialektyką »odstępowania i powrotu do tego, co pierwotne«, człowiek zaś, w którym ów rytm przeradza się w »doskonałą świadomość", niczym innym niż jednością sprzeczności bytu najbardziej doskonałego i najbardziej niedoskonałego"; tamże, s. 152.

${ }^{28}$ Por. tamże, s. 201; por. W. Klaghofer-Treitler, Gotteswort im Menschenwort: Inhalt und Form von Theologie nach Hans Urs von Balthasar, Tyrolia Verlag, Innsbruck 1992, s. 74-75. 
Ponieważ trudno dokonać całościowego opisu poszczególnych postaci i ich znaczeń, Balthasar dochodzi do przekonania, że istnieje jedna centralna, wewnętrzna zasada charakteryzująca i najgłębiej wyjaśniająca drogę od Kanta do Hegla. Tą zasadą jest „mistyczna potencjalność”. Analizując strukturę filozofii Fichteańskiej, Balthasar stwierdza: „Z tej podstawowej struktury, którą w takiej formie po raz pierwszy buduje Fichte, rozwija się niczym z jednego korzenia cały idealizm niemiecki. Najpierw jego obraz świata, później nieuchronnie także cała jego egzystencjalność, życie świata. Dlatego chcemy tę strukturę ująć terminem pozwalającym rozpoznać ją we wszystkich jej »przebraniach « i metamorfozach, i nazywać ją »mistyczną potencjalnością «"29.

Mistyczna potencjalność jest, jak stwierdza Balthasar, terminem, który w swoich badaniach nad antycznym i średniowiecznym pojęciem możliwości wprowadził August Faust ${ }^{30}$, omawiając Plotyński stosunek tego, co istnieje po prostu, i tego, co relatywnie absolutne. Balthasar widzi tym samym idealizm jako odnowienie myśli Plotyna, stanowiącej „środek między metafizyką starogrecką i chrześcijańską"31.

${ }^{29}$ AP I, s. 176.

${ }^{30}$ August Faust (1895-1945) - niemiecki profesor filozofii, po roku 1933 zdecydowany zwolennik narodowego socjalizmu, od 1937 członek NSDAP. Jego zainteresowania filozoficzne koncentrowały się na filozofii transcendentalnej Kanta i Fichtego oraz na historii filozofii. Wprowadzając pojęcie mistycznej potencjalności, Balthasar powołuje się na pracę Fausta Geschichte des Möglichkeitsbegriffs (por. AP I, s. 176). Chodzi tutaj zapewne o obszerny tekst Beiträge zur Geschichte des Möglichkeitsproblems, którego fragmenty stały się częściowo podstawą niepublikowanej pracy habilitacyjnej Fausta z 1927 roku, a który swe rozwinięcie znalazł kilka lat później w jego głównym, dwutomowym dziele Der Möglichkeitsgedanke. Systemgeschichtliche Untersuchungen, 1. Teil: Antike Philosophie, 2. Teil: Christliche Philosophie, C. Winter, Heidelberg 1931-1932 (reprint Garland Pub., New York 1987).

31 AP I, s. 177. 
W rozważaniach poświęconych myśli Goethego Balthasar stwierdzi, że mistyczna potencjalność to w swej istocie „forma pośrednia między boską, czystą aktualnością i potencjalnością stworzenia. Próbuje ona (...) to, co paradoksalne, identyczne, niepotrzebujące, wieczne, ustawić w koniecznej relacji do nieidentycznej, potrzebującej, czasowej podstawy. Krzew gorejący był tego parabolą" 32 . W nawiązaniu do Plotyńskiej koncepcji jedności mistyczna potencjalność jest kontekstem myślowym pojawiającym się wówczas, gdy próbujemy wyobrażać sobie jedność Bożej możności stwarzania i jej aktualizacji w świecie. Ten sposób myślenia przyjmuje charakter dialektyczny, w którym początek i źródło zaistnienia rzeczywistości są jednocześnie pojmowane w całości poszczególnych bytów. Dwa różne elementy, jakimi są możliwość i całość, pomyślane zostają jako momenty relacji, przedstawianej jako odnoszenie się do tego, co ją przekracza, do Jednego. Relacja ta w swej logicznej strukturze zawiera zatem również negację, wynikającą z jedności: samoodniesienia i negacji. W perspektywie eschatologicznej, rozumianej jako historyczne odniesienie do tego, co ostateczne, struktura mistycznej potencjalności ważna jest przede wszystkim jako czasowo ukonstytuowany ruch ku jakiemuś celowi. W ruchu tym widoczny jest jednocześnie ponadczasowy początek, stanowiący zalążek pełnego objawienia się całości. Celowość ta musi zostać dopiero przez Balthasara określona w całościowej strukturze procesu rozwoju myśli idealistycznej na drodze filozoficznej od Kanta do Hegla.

32 Tamże, s. 435. 


\section{Johann Gottlieb Fichte. Wolność podmiotu a nieskończoność}

W filozofii Fichtego Balthasar chce widzieć przede wszystkim przełamanie kantowskiego podmiotu, który sam z siebie nie jest zdolny osiągnać eschatologicznej integralności. Kantowskie pozostawanie w granicach doświadczenia i niemożność ostatecznego spełnienia się zostają w myśli Fichteańskiej przezwyciężone w jedności obecnego dla siebie podmiotu. Fichte wychodzi od zasady Ja jako doskonałego, wolnego posiadania siebie w czynie oraz oglądzie siebie ${ }^{33}$.

Podmiot staje się prometejskim symbolem przezwyciężania wszystkich przeciwności dzięki absolutnej sile i energii, która wspiera go w ponadnaturalny sposób. Działający podmiot, podmiot moralny, ma w sobie moc dopełnić swoją wolność, ponieważ jest poruszany z własnego wnętrza przez wolność absolutną, która się w nim rozwija. W ten sposób rozważania Balthasara nad filozofią Fichtego wprowadzają nas w refleksję nad pojęciem wolności. Dynamizm stawania się kantowskiego podmiotu i oczekiwania w ciągłym niepokoju zostaje w filozofii Fichtego wyciszony przez wyższą świadomość, jaką daje doświadczenie wolności. Człowiek to podmiot, który jest w stanie osiągnąć wolność, albowiem wolność absolutna daje się niejako sama, chcąc jednocześnie zawładnać podmiotem. Zainteresowanie Balthasara filozofią Fichtego, obok wielu innych powodów, bierze się przede wszystkim z faktu wprowadzenia przez niego do filozofii pojęcia neoplatońskiej partycypacji w Bogu (Nie-Innym). Wolność skończona, charakteryzująca działanie podmiotu, może naśladować rozwój wolności Absolutu, znajduje u siebie, w swoim wnętrzu, konieczność działania, zaangażowania się, bo w swojej głębi czu-

\footnotetext{
${ }^{33}$ Por. CH III/1/2, s. 499.
} 
je się poruszana przez wyższą wolność, w której ma możliwość uczestniczyćc ${ }^{34}$.

Idąc w ślad za Kantem, Fichte łączy uświadomienie wolności z momentem, w którym podmiot transcendentalny urzeczywistnia coraz bardziej własną autonomię. Jego filozofia konstruuje podstawy wiedzy, która doświadczanie wolności widzi w perspektywie nieprzekraczającej granic tego świata. W ten sposób wiedza pozostaje zależna od kategorii intelektu, schematów myślenia, jakimi wolność posługuje się w urzeczywistnianiu samej siebie. Ostatecznie prawdziwe urzeczywistnianie się wolności realizuje się w skończoności podmiotu poprzez korzystanie ze struktur filozofii transcendentalnej i schematów idealnych. Dynamizm aktywnej działalności podmiotu daleki jest od rezygnacji ze swych możliwości i pozostawienia przestrzeni dla zaistnienia daru ze strony dającego się Absolutu. Czy zatem fichteański podmiot może jeszcze w jakiś sposób urzeczywistniać realizację wolności bez odwoływania się tylko do samego siebie?

\subsection{Idealizm mistyczny}

Nie ulega wątpliwości, że Fichte postrzegany jest przez Balthasara najpierw jako przedstawiciel filozofii transcendentalnej. Punktem wyjścia jego filozofii, podobnie jak u Kanta, jest refleksja nad doświadczeniem podmiotu w rozwoju własnej wolności. Fichte nie stawia rozumowi żadnych granic i nie zastanawia się, czy takowe istnieją. Refleksje filozoficzne skierowane są ku świadomości wyjątkowego wydarzenia, jakim jest wolność w swej ogromnej mocy. Balthasar zdaje sobie sprawę, że Fichte, chcąc do-

34 Pierwotny akt wolności nie prezentuje się jako przedmiot, jest całkowicie nie-przedmiotowy. Wydaje się, że takim myśleniem wpisuje się Fichte w myśl mistyczną Plotyna, w której istota wolności wyrażana jest właśnie słowami o nie-inności, o nie-rzeczy, a tym samym o samości tożsamości. 


\section{$110 \quad * \quad$ Hans Urs von Balthasar wobec idealizmu niemieckiego}

konać opisu doświadczenia wolności zawartej w głębi podmiotu transcendentalnego, musi uciec się do skonstruowania innego języka, nieopartego na pojęciach kantowskich. Dynamizmu wolności nie da się opisać za pomocą statycznych kategorii, takich jak byt czy też przedmiotowość. Trudno też posłużyć się kategoriami intelektu dyskursywnego, które ciągle odwołują się do naocznego przeżycia. Musi się zatem posłużyć kategoriami należącymi do obszaru mistycznego doświadczenia i przeżycia.

Wydaje się, że Fichte zmierza drogą prowadzącą do odkrycia pewnego rodzaju intuicji, która wprowadzi go w obszar terminologii mistycznej. Akt wolności traktuje Fichte jako moment pierwotny, który daje się podmiotowi i nie jest niczym poprzedzony. Myśl idealistyczna traktuje wolność jako jedyną daną rzeczywistość pozytywną. Wolność nie może być w ten sposób utożsamiana z bytem, nie ma charakteru stałego i statycznego. To przede wszystkim działanie i, chciałoby się powiedzieć, nic więcej. Trudno też twierdzić, że wolność jest czymś działającym, ponieważ sugerowałoby to, iż wolność jest bytem jak inne byty i jako bytowi zdarza się jej działanie ${ }^{35}$.

U podstaw refleksji nad aktywnością podmiotu Fichte stawia zatem akt oglądu intelektualnego (intellektuale Anschauung), który rozumie jako „takie przypisane filozofowi oglądanie samego siebie przy spełnianiu aktu, w którym powstaje dla niego Ja (...). Jest to bezpośrednia świadomość tego, że działam i jak działam: jest to coś, dzięki czemu coś wiem, ponieważ to robię. Za pomocą pojęć nie da się wykazać, że istnieje władza takiego oglądu intelektualnego, i z pojęć nie można wywieść, czym on jest. Każdy musi odnaleźć go bezpośrednio w sobie samym, inaczej nie pozna go nigdy" 36 .

\footnotetext{
35 Por. AP I, s. 160.

${ }^{36}$ J.G. Fichte, Teoria wiedzy, dz. cyt., s. 510-511.
} 
Zadaniem tak rozumianego oglądu jest ukazanie wewnętrznego ruchu podmiotu ku własnej tożsamości. ,Jedynie w ja jako oglądzie intelektualnym znajduje się forma jaźni, (...) powracające do siebie działanie, (...) Ja w takiej postaci istnieje wyłącznie dla filozofów" ${ }^{37}$. Pozwala on także zdać sobie sprawę z doświadczenia tożsamości Absolutu, który jest ostatecznie podstawą wszystkiego, co istnieje. Intuicja nie jest uprzedmiotawiającą analizą warunków możliwości wolności, lecz raczej ruchem w kierunku tego, co stanowi w ogóle o wolności. Jako posiadanie siebie wolność musi być intuicyjnie postrzegana przez tego, który się w niej ukazuje. W myśleniu Fichtego dostrzega Balthasar taki sposób rozumienia, w którym wolność skończona, by odnaleźć to, co ją wyróżnia spośród bytów, musi dać się ponieść ku głębi Absolutu. Wtedy podmiot ludzki może zostać skierowany w przestrzeń, w której może doświadczyć swojego bytu o wiele bardziej, niż gdyby to czynił jedynie ze swej skończoności. W ten sposób podmiot człowieka staje się obrazem i odbiciem podmiotu nieskończonego, który unosi go ku wolności.

W transcendentalnej filozofii Fichtego Balthasar dostrzega zatem rozumienie wolności w sensie nieskończonego ruchu przekraczania siebie. Podmiot przystaje do wolności, w miarę jak mierzy się z przeciwieństwami, wobec których stawiają go natura i świat przedmiotowy, świat rzeczy. Mimo wewnętrznych ruchów świadomości podmiot nastawiony jest na działania świata zewnętrznego, ma swoje w nim miejsce. Jego duchowa natura, otwarta na rozwój wolności, podlega różnym wpływom świata, które mogą zagrażać życiu jego ducha. Opór rzeczy może jednak prowokować go do zdecydowanego działania, do nieustannego przeciwstawiania się mu i wznoszenia się w wolności ponad wszelkie przeciwności, by ostatecznie posiadać tylko siebie. Fichteański podmiot szuka nie-

${ }^{37} \mathrm{CH}$ III/1/2, s. 500. 


\section{$112 \quad$ Hans Urs von Balthasar wobec idealizmu niemieckiego}

ustannej konfrontacji swojej wolności z wszystkimi wydarzeniami rzeczywistości, które jakoś przecież wypełniają jego istnienie. Rozwój wolności wydaje się procesem nieskończonym, chyba że wszystkie rzeczy wokół niego zostaną obdarzone zdolnością przemiany. I znowu powstaje pytanie: czy podmiot moralny, podobnie jak u Kanta, wezwany do nieustannego działania, nie poczuje się zbytnio obciążony przezwyciężaniem wszelkich przeszkód, łamaniem oporu natury oraz wszystkiego, co stanowi nie-ja?

\subsection{Dialektyka Ja}

Idealizm Fichtego jako próba zawładnięcia centrum świata przez podmiot to wyraźny przykład działania prometejskiego. Punktem wyjścia jego filozofii jest sformułowana w Teorii wiedzy z 1794 roku zasada ustanawiającego siebie samego Ja, w którym znajduje się struktura wszelkiej wiedzy teoretycznej i praktycznej. Ja ustanawia samo siebie i samemu sobie przedstawia Nie-Ja. Ustanawianie i przeciwstawianie należy rozumieć jako działanie jednego i tego samego Ja oraz jako zmianę jednego i tego samego aktu. W ten sposób wypowiedziana zostaje treść zasady mistycznej potencjalności, w której myśl o jedności tego, co absolutnie relatywne, oraz tego, co po prostu absolutne, tworzy ruch dialektyczny. W ruchu tym ustanawianie i przeciwstawianie można ze sobą połączyć tylko wtedy, gdy wprowadzi się możliwość samoograniczenia ustanawiającego Ja. Ograniczenie implikuje zaś wprowadzenie możliwości podzielności, a zatem pewnej zdolności ujęcia ilościowego ${ }^{38}$. W ten sposób Nie-Ja jawiłoby się jako stopniowo zmniejszona aktywność Ja, a samo przeciwstawienie byłoby zmniejszonym ustanawianiem.

W konsekwencji takiego patrzenia absolutne i niepodzielne Ja można by sobie wyobrazić jedynie jako proces przyswajania

${ }^{38}$ Por. J.G. Fichte, Teoria wiedzy, dz. cyt., s. 70-71. 
ustanowionego Nie-Ja. Ale w takim wypadku absolutne Ja jawiłoby się jako absolutne „po prostu” i absolutne w czasowym znaczeniu nieskończonego zbliżania. Istnieje zatem Ja jako ponadczasowa przyczyna oraz Ja pomyślane jako ograniczone czasem, ale widziane jako rosnąca totalność określeń. Obydwa znaczenia są bardzo bliskie sobie, jednak pozostają ciągle rozłączne. Według Fichtego, postać absolutnego Ja występującego w dwóch znaczeniach da się wyjaśnić w perspektywie przejścia z Ja teoretycznego do praktycznego. Ja absolutne dąży wtedy do tego, by znieść każdą formę Nie-Ja i podziału siebie, do osiągnięcia pełni jedności z samym sobą ${ }^{39}$.

Nie ulega wątpliwości, że punktem wyjścia filozofii Fichtego jest wolność Ja. Jest ona jednak postrzegana w bezpośrednim stosunku do Ja absolutnego (boskiego), które umiejscawia się jakoś w podmiocie. Ja człowieka odnajduje siebie w nieustannym dynamizmie zdobywania wolności, w walce, którą toczy przeciwko oporowi Nie-Ja. Zadanie to podejmowane jest w ciąłłej relacji do Ja absolutnego, które wypełnia całą rzeczywistość. Wolność jest podstawowym ruchem i stawaniem się, jej spełnienie dokonuje się, gdy Ja przezwycięża opór wywołany przez Nie-Ja. Podstawową regułą działającą $\mathrm{w}$ tym procesie jest ta, że wolność dopełnia się jakby dla-siebie przez opór Nie-Ja ${ }^{40}$, pochodzi z samej istoty Ducha, wznosi ponad siebie samą, ponad to, co jest jej w sposób absolutny przeciwne ${ }^{41}$.

Z punktu widzenia wolności absolutnej Fichte postuluje zasadę, według której „Ja ustanawia siebie poprzez działanie Nie-Ja”42. Także wolność absolutna znajduje się w konfrontacji do Nie-Ja. Nigdy nie jest ona niezależna, ponieważ zawsze wiąże się z naci-

\footnotetext{
${ }^{39}$ Por. tamże, s. 305.

${ }^{40}$ Por. AP I, s. 168.

${ }^{41}$ Por. tamże, s. 160.

${ }^{42}$ Tamże, s. 170.
} 


\section{$114 \quad$ Hans Urs von Balthasar wobec idealizmu niemieckiego}

skiem „natury” i „nie-wolności”. W ten sposób wolność ubogaca się, w miarę jak przezwycięża wyzwania stawiane ciągle przez nie-wolność. Sfera Nie-Ja ukazuje się jako konieczność, którą wolność wywołuje z siebie i dla siebie. Wolność absolutna prowokuje moc, która jej się sprzeciwia i której w pewnym sensie potrzebuje jako konieczny bodziec do stałego wzrostu aktywnej energii.

Fichte przenosi schemat dotyczący wolności absolutnej na płaszczyznę ducha skończonego, gdzie podmiot transcendentalny $\mathrm{w}$ walce $\mathrm{z}$ przeciwnościami Nie-Ja kroczy ciągle do przodu. Balthasar pyta: „Kim jest owo tożsame ze sobą ja, od którego wychodzi Fichte, odpowiedź musi brzmieć: ani Bogiem, ani człowiekiem. Nie jest Bogiem, ponieważ On znajduje się poza wszelką refleksją zakładającą nie-ja oraz każdym ujęciem wolności przez siebie zakładającym powinność i dlatego raz na zawsze nie może być myślany wedle wiodących idei samoświadomości i osobowości. Nie jest również człowiekiem, ten bowiem jest wciąż skończoną świadomością siebie, nigdy czystym ja" ${ }^{43}$. Człowiek osadzony $\mathrm{w}$ świecie postrzegany jest jako ten, który nieustannie spełnia zadanie uwierzytelniania własnej wolności. Wysiłki, jakie podmiot musi podjąć, by wznieść się ponad nie-wolność, są tak wielkie, że wydaje mu się, iż przekraczają jego możliwości. Podmiot zdany tylko na siebie może mieć nadzieję, że walka z przeciwnościami doprowadzi go do zwycięstwa nad samym sobą. W ten sposób wierzy, że osiągnie „rzeczywistość” eschatologiczną, tak mocno oczekiwaną w tym świecie. „Podstawowe twierdzenie filozofa jako takiego jest następujące: podobnie jak Ja jest tylko dla samego siebie, tworzy się dla niego jednocześnie w sposób nieunikniony bycie poza nim; przyczyna drugiego leży w pierwszym, drugie jest uwarunkowane pierwszym"44. Wydaje się to możliwe dzięki

\footnotetext{
${ }^{43}$ CH III/1/2, s. 500.

${ }^{44}$ AP I, s. 171-172.
} 
mistycznej relacji z wolnością absolutną. Podmiot skończony jest w niej zdolny do ruchu, który go unosi do możliwości zrozumienia, że nie-ja, któremu nieustannie się sprzeciwia, sprawia, iż jego wolność zostaje wyniesiona do wyższego poziomu ${ }^{45}$.

Podmiot transcendentalny winien ciągle wsłuchiwać się w impuls, który poprowadzi go ku wolności. Tak naprawdę rządzi nim bowiem moc wolności absolutnej, którą Fichte określa mianem absolutnej energii (Tathandlung). Z pomocą światła ducha absolutnego nic nie jest w stanie zatrzymać go na drodze ku realizacji swojej wolności. Przeciwnie, jeśli podmiot nie podda się działaniu wolności absolutnej, może stać się przedmiotem gry anonimowych, fatalnych sił rządzących światem. W afirmacji siebie i przeznaczenia związanego z duchem absolutnym człowiek znajduje siłę, by odnieść zwycięstwo nad skończonością.

Balthasar przywołuje słowa Fichtego: „Śmiało wznoszę swą głowę ku górze, ku groźnym skalistym szczytom, ku szalejącemu wodospadowi, ku grzmiącym obłokom płynącym po morzu ognia, i mówię: jestem wieczny, i opieram się waszej potędze! Padnijcie przede mną wszystkie, ty, ziemio, i ty, niebo, zbijcie się w szalonym tumulcie, i wy, wszystkie żywioły, wrzyjcie i szalejcie, by w dzikiej walce zetrzeć ostatni słoneczny pyłek ciała, które nazywam własnym [ciałem] - sama moja wola ze swoim śmiałym planem winna mężnie i trzeźwo unosić się nad ruinami świata, albowiem podjąłem swe powołanie, a ono jest trwalsze niż wy, ono jest wieczne, więc i ja, jak ono, jestem wieczny"46.

${ }^{45}$ Człowiek może i powinien walczyć z wszelkimi przeciwieństwami, gdyż jest w stanie odnieść zwycięstwo. Jeśli chce być wierny swej naturze, musi dostrzegać we wszystkim, co stanowi nie-ja, możliwość wyzwolenia większej energii.

${ }^{46}$ J.G. Fichte, Kilka wykładów o powołaniu uczonego, tłum., wstęp i oprac. T. Kupś, Wydawnictwo Naukowe UMK, Toruń 2012, s. 62; por. AP I, s. 177. 


\section{Hans Urs von Balthasar wobec idealizmu niemieckiego}

\subsection{Nieskończoność i struktura egzystencjalna}

Balthasar pozytywnie patrzy na dialektyczny ruch wynikający z przedstawionej przez Fichtego struktury mistycznej potencjalności, jedności tego, co absolutnie relatywne, i tego, co po prostu absolutne. Sprzeciwia się jednak poglądowi Fichtego, który najwyraźniejszą jedność Ja widzi w Ja praktycznym. Dla Balthasara takie ujęcie wydaje się powrotem do stanowiska Kantowskiego, które pozostawało w obszarze immanencji, czy też transcendencji ukrytej w immanencji. Myśl Balthasara od początku dążyła do przezwyciężenia dualizmu, który w postaci Ja i Nie-Ja pozostaje ciągle niezniesiony. Nawet jeśli jest mowa o dążeniu lub transcendowaniu każdej formy podziału, to dążenie nadal pozostaje, przyjmując postać dążenia wiecznego: „Pełnią szczęścia jest jednak wieczne wzajemne przenikanie się przemienionej kontemplacji i przemieniającego czynu" ${ }^{47}$. Balthasar dostrzega tutaj pewną zależność Fichteańskiej eschatologii od myśli Kanta. Uważa jednak, że „Kantowska synteza eschatologiczna poddana została dziwnej, lecz koniecznej końcowej interpretacji zmierzającej w kierunku dualizmu, pod warunkiem że synteza ta o d nosi się właściwie tylko do Boga, a dla nas nigdy nie staje się rzeczywista. Jedynie bowiem dla Boga, prawdziwie Wiecznego, nieskończony ciąg czasowy naszego przybliżania się jest już dokonany, zakonczony, podczas gdy my wiecznie pozostajemy w czasie"48.

W ten sposób w filozofii Fichtego radykalizuje się „ów dualizm ku temu, co wieczne, opór, immanentny wszelkiemu dokonaniu, staje się immanentny samej wieczności i jej szczęściu. Dopiero w pełni osiągnięta struktura mistycznej potencjalności mogła pod-

\footnotetext{
${ }^{47}$ AP I, s. 187.

48 Tamże.
} 
nieść cierpienie w sferę szczęścia, a przez to uzasadnić właściwą eschatologię egzystencjalną człowieka prometejskiego"49.

Fichte jest ciągle bliski rozważaniom Balthasara, który próbuje prześledzić zmiany jego myślenia w późniejszych pismach. Wskazuje, że po roku 1800 w miejsce dualizmu Ja i Nie-Ja Fichte przedstawia propozycję nowego rodzaju relacji dialektycznej immanencji i transcendencji, człowieka i Boga. Na podstawie tekstu z 1806 roku zatytułowanego Anweisung zum seeligen Leben Balthasar uważa, że relacja „człowiek i Bóg”, „immanencja i transcendencja” da się scharakteryzować przez wyjaśnienie faktu, iż podstawową myślą Fichtego nie jest już dążenie do praktycznego Ja, do jedności ze sobą, lecz unoszenie się religijnie nastrojonego Ja między czynem absolutnym a oddaniem się Absolutowi.

Formuła mistycznej potencjalności stała się podstawowym określeniem tajemnicy nieskończoności. Ujęta w postać egzystencjalną tworzy ona strukturę ostatecznej postawy człowieka. Opis egzystencjalności mistycznej potencjalności ma zmierzać do przedstawienia teorii Absolutu, a nie stanowić jedynie opis relacji kontemplacji i czynu w tym, co skończone. W ten sposób eschatologia Fichtego przybiera charakter religijno-filozoficzny ${ }^{50}$.

Czy jednak w ten sposób najważniejsza Fichteańska zasada nie jest już gwarantem mistycznej potencjalności czynu? Nie ma bowiem miejsca na zjednoczenie czynu i kontemplacji Boga. Pozostaje stan niejako pośredni: „unoszenie się” między działaniem a oddaniem się Absolutowi. Ze względu na ten właśnie charakter „unoszenia się” prometejska filozofia Fichtego rozpada się na dwa kierunki. „Tak zatem Fichte jest bohaterem Prometeuszem: w swej dwojakiej postawie wizjonerskiego wstępowania ku temu, co na górze, oraz twórczego panowania w tym, co na dole; pro-

\footnotetext{
${ }^{49}$ Tamże, s. 187-188.

${ }^{50}$ Por. tamże, s. 189.
} 


\section{$118 \quad$ Hans Urs von Balthasar wobec idealizmu niemieckiego}

metejski przez zagarnianie ku sobie centrum świata, które Bogu daje świadomość, a światu boskość; jednak to heroiczność przemieniona w prawdziwie niemieckie bohaterstwo Zygfryda; podwójna jedność dziecka i pogromcy smoków" ${ }^{51}$. Wobec tego, co w górze, Fichte jest „dzieckiem” znajdującym się w wizjonerskim uniesieniu ku Bogu; wobec tego, co w dole, nadal pozostaje człowiekiem czynu ${ }^{52}$.

W tym miejscu uwidocznia się następna wątpliwość Balthasara w stosunku do początkowych założeń koncepcji Fichtego: czy czasem fichteański podmiot zbyt wielkiej części swojego dynamizmu stawania się w historii nie przenosi na realny i transcendentny fakt swojej partycypacji w wolności? Jeśliby tak było, to wówczas współpraca z wolnością absolutną (boską) byłaby tylko pozorna, bowiem odnajdywałaby siebie jedynie w świadomości pewnej mocy właściwej samemu podmiotowi. W tym miejscu interesują Balthasara struktury, które pozwoliłyby na stworzenie przestrzeni dla samego Boga, a tym samym jakiejś rezygnacji, wyrzeczenia się podmiotowych możliwości. Balthasar śledzi rozwój myśli Fichtego, która zdaje się ewoluować w kierunku połączenia boskiego nie-innego świata z aktywnością ludzkiego podmiotu, mającego się ostatecznie zanurzyć, niejako oddać temu światu.

Krytyczne spojrzenie Balthasara na system Fichtego dotyczy także redukcji Absolutu i podmiotu do tej samej płaszczyzny działania. W podmiocie transcendentalnym Absolut przyjmuje rolę spełnienia, które podmiot stawia przed sobą. Wydaje się, że podmiot potrafi sobie wyobrażać swoje zdolności, zanim jeszcze zostaną one w pełni zrealizowane, podobnie jak Absolut, który przechodzi z możności do aktu. Takie nastawienie na realizację

51 Tamże, s. 201.

${ }^{52}$ Według Hegla, system Fichtego nie potrafi połączyć początku z końcem i trwa ciaggle w dualizmie. Por. G.W.F. Hegel, Wykłady z historii filozofii, t. III, tłum. i przypisy Ś.F. Nowicki, PWN, Warszawa 2002, s. 582. 
swojej wolności w podmiocie, jak już zostało zauważone, Fichte nazywa „mistyczną potencjalnością”. Podmiot transcendentalny widziany jest wtedy na wzór absolutnego działania, w którym podejmuje się próbę wyobrażenia sobie jedności Bożej możności stwarzania i jej aktualizacji w świecie. Absolut afirmuje siebie poprzez swą obecność $\mathrm{w}$ świecie poddanym potencjalnemu procesowi stawania się. Dlatego też Absolut i podmiot transcendentalny postrzegane są $\mathrm{w}$ perspektywie ich potencjalności we wzrastaniu, zmierzającej ku coraz większej i aktywnej energii.

$\mathrm{Z}$ jednej strony Ja absolutne na mocy swego wewnętrznego prawa winno nieustannie wzrastać, z drugiej zaś może to czynić tylko w momencie, kiedy Ja skończone przekracza siebie i czyni to w mocy Absolutu. W ten sposób dochodzimy do sytuacji typowo prometejskiej. Podmiot nie porusza się w przestrzeni, w której znajdował się w relacji posłuszeństwa do Boga, udzielającego się osobowo i dobrowolnie. Balthasar pyta: „Kto jednak może u Fichtego tak wzywać, że skończona osoba samą siebie potrafi określić poprzez to wezwanie oraz podjąć je w duchu całkowitego posłuszeństwa?" 53 .

Wydaje się, że proces stawania się wolności dokonuje się w perspektywie panteistycznej. Dane empiryczne wolności są przenoszone na wolność absolutną, podczas gdy droga odwrotna charakteryzuje się tym, że wolność podmiotu jest przyodziana w struktury konieczności, które zmierzają z powrotem do wolności absolutnej. Myśl Fichtego dotycząca wolności rozwija się zatem na dwóch płaszczyznach. Płaszczyzna ludzkiej wolności nakłada się na płaszczyznę wolności absolutnej. To, co jawi się jako ważne w wolności absolutnej, to jej podobieństwo do wolności ludzkiej, które ostatecznie zostaje zatarte poprzez działanie wolności Absolutu.

${ }^{53} \mathrm{CH}$ III/1/2, s. 502. 


\subsection{Płaszczyzna religijna}

Czego potrzeba idealizmowi, by mógł wejść na religijną drogę refleksji? Balthasar uważa, że idealizm skupia się przede wszystkim na dynamizmie spełnienia, które człowiek sam sobie przypisuje. Podmiot powinien jedynie relatywnie nadać znaczenie swoim siłom, ludzkim możliwościom. Tylko wtedy, gdy zrezygnuje z własnego marzenia o doskonałości, całości, będzie mógł otworzyć się na działanie daru i będzie wolny od możliwości przywłaszczenia go sobie jako jedynie własnego. Według Balthasara, Fichte w ostatnich latach twórczości doszedł do wniosku, że wiedza winna zrezygnować ze swoich roszczeń do całości i ustąpić miejsca Temu, który chce się uobecnić we wnętrzu człowieka. Myśl sama z siebie wytwarza tylko puste pojęcia, niezdolne do autentycznego pobudzenia podmiotu do życia. Myśl dostarcza tylko schematu. Wiedza pozostaje na zawsze wiedzą uprzedmiotawiającą, nieprawdziwym życiem, stanowi jedynie cień prawdziwej rzeczywistości ${ }^{54}$. Schematy mogą być jedynie sposobem uobecniania się Bożego życia w świecie, pośród rzeczywistości skończonych. "Jest tylko jeden byt, który istnieje przez siebie, mianowicie Bóg; a Bóg nie jest pojęciem bez życia, które wzywamy, lecz jest On życiem w sobie samym, i [to] w sposób całkowity (...). Cały Byt jest Bytem przez swój Byt, i w jego Bycie cały Byt jest nam dany; niezależnie od tego żaden Byt nowy nie może istnieć ani w Nim, ani poza Nim. Tymczasem, wiedza jest, nie będąc wcale samym Bogiem; nie może więc, ponieważ nic innego nie istnieje poza Bogiem, być Bogiem pod postacią istnienia "poza sobą samym« (...). Właśnie taka forma stanowi istnienie obrazu czy schematu" 55 .

\footnotetext{
${ }^{54}$ Por. AP I, s. 166.

55 Tamże, s. 195.
} 
Wiedza umieszcza podmiot w miejscu, w którym jest świadom faktu, iż jego możliwości pochodzą od przedmiotu. W momencie kiedy wiedza próbuje zrozumieć życie Boże, istnieje niebezpieczeństwo, że redukuje je do wąskich granic ujęcia uprzedmiotawiającego. „Z racji, że wiedza przykłada się do opisania i wychwycenia tego, co się wyróżnia, to, czym życie Boże jest absolutnie samo przez się, zostaje sprowadzone do samego życia myśli, do Bytu statycznego i skostniałego" ${ }^{56}$. Pojawia się w ten sposób tajemnicza więź, która łączy życie boskie z tym, co ukazuje się w wiedzy ludzkiej. To, co wiedza dostrzega z życia boskiego, winno odnosić się do niego samego, oczywiście tylko na tyle, na ile ono samo wyraża się poza sobą jako „odbicie” czy pewien „obraz”. W tym kontekście obraz może oznaczać także obecność.

Życie przedstawione za pomocą pojęcia staje się określoną formą, w której sam Bóg postanowił żyć jakby poza sobą. Wydaje się, że z drugiej strony ta forma powinna stanowić pewną bramę, przez którą istnieje możliwość przejścia do życia Bożego. Forma jednak nie może w pełni ukazać i zawierać w sobie obecności boskiej dopóty, dopóki nie otworzy się na moc życia samego Boga. Staje się to możliwe w chwili, gdy wiedza niejako usuwa się na drugi plan. Poznający i działający podmiot powinien zdać sobie sprawę, że aby zrobić miejsce tajemnemu działaniu życia Bożego, musi oddalać się od myśli przedmiotowej. Balthasar uważa, że w rozwoju swojego systemu Fichte powoli dochodzi do momentu, w którym uświadamia sobie, iż podmiot, usuwając się w swoich badaniach prawdy w cień, staje się coraz bardziej zdolny do oddania się ukrytemu źródłu życia. Fichte, według niego, zdaje sobie sprawę, że aby poznać prawdę, trzeba prowadzić życie oparte na posłuszeństwie ${ }^{57}$. Podmiot określa siebie ostatecznie

\footnotetext{
56 Tamże.

${ }^{57}$ Por. tamże, s. 181.
} 
w swojej wolności przez wymagania Bożego życia, które staje się życiem w nim samym. Filozofia religijna Fichtego czyni, według Balthasara, częste aluzje do wzniosłej misji zleconej człowiekowi. Polega ona na tym, że człowiek przez swoją całkowitą przejrzystość i całkowite oddanie ma stać się w świecie stworzonym żywym obrazem Boga. Podmiot będzie o tyle bardziej wierny swojej misji, o ile pozwoli się pochłonąć przez życie Boże, rozchodzące się w nim w najwyższym stopniu ${ }^{58}$.

Balthasar uznaje ostatecznie, że filozofia religijna Fichtego w jego ostatnich dziełach dochodzi do poziomu piękna, którego idealizm w przedstawieniu postaci tego świata nigdzie nie osiąga. I to właśnie tam Fichte stawia przed życiem propozycję postawy - Plotyńskiej i Janowej - na mocy której człowiek pozwala się porwać przez wyższe piękno, jakie się przez niego przejawia. Niemniej jednak zadaje pytanie, czy prawdziwa postawa religijna, tu obecna, nie jest mimo wszystko pozbawiona sił przez niepokoje, zawsze w jakiś sposób nierozłącznie związane z filozofią transcendentalną, która zapewnia człowiekowi środki samodzielnego dojścia do własnego spełnienia osobowego. Czy nie znajdujemy

${ }^{58}$ „Najlepiej ujmuje cię dziecięca, oddana ci prostota. (...) Jesteś dla niej matką, która jest zawsze dla niej dobra, która wszystko zmieni dla niej na lepsze. (...) Uczyń ze mną, jak zechcesz - mówi ona - wiem, że to będzie dobre, ponieważ Ty to czynisz. Mędrkujący rozum, który tylko o tobie słyszał, nigdy cię nie widział, pragnie dać nam poznać twoją istotę samą w sobie i stawia przed oczy pełnego sprzeczności potwora, podając go za twój obraz, widok dla człowieka tylko rozsądnego śmieszny, a dla mądrego nienawistny i wstrętny. Zasłaniam przed tobą oblicze moje i kładę rękę na ustach. Jaką jesteś dla siebie samej i jaką się sobie samej wydajesz, nie zdołam nigdy dociec, ponieważ nie mogę stać się tobą. (...) Ty s prawias z we mnie poznanie mego obowiązku, mego powołania w szeregu istot rozumnych. (...) Ty wi es z i poznajesz, co ja myślę i czego chcę. (...) Ty ch cesz, ponieważ chcesz, aby dobrowolne posłuszeństwo moje miało skutki po wieczne czasy"; J.G. Fichte, Powołanie człowieka, tłum. i wstęp A. Zieleńczyk, Hachette, Warszawa 2010, s. 106; por. AP I, s. 202-203. 
tu mimo wszystko, nawet jeśli w sposób ukryty, obecności schematu mającego jeszcze mocne podobieństwa do „mistycznej potencjalności”? Fichte z pewnością nie ogranicza się w swoim systemie do potwierdzenia ważności podmiotu w obliczu jego działania i oporów wobec Nie-Ja. Owszem, dynamiczna interpretacja podmiotu zostaje w pewien sposób zamazana, by zrobić miejsce niezmąconej postawie oddania i przejrzystości. Niemniej jednak wolno raz jeszcze zapytać, czy ta postawa nie opiera się ostatecznie na interpretacji, według której człowiek pojmuje siebie jako „moc” istniejącą na pełnych prawach w relacji z Absolutem. Tak więc schemat „mistycznej potencjalności” nie przestaje funkcjonować, choć dzieje się to w mniejszym stopniu, może w sposób subtelny i ukryty. Co człowiek pragnie w rzeczywistości osiągnąć, oddając się Absolutowi? Czy chce naprawdę uczynić się narzędziem „biernym”, które całym swoim bytem nabiera dystansu do siebie, aby być zdeterminowanym jedynie przez suwerenną wolę Boga? Czy może przeciwnie, człowiek pragnie wyrzec się siebie, by już przez sam ten akt wznieść się ku większej pełni, by ukazało się w nim doskonale życie Boże? W tym ostatnim przypadku myśl nie byłaby jeszcze uwolniona od perspektywy prometejskiej. Balthasar posługuje się porównaniem do klepsydry: nawet w momentach subtelnych, kiedy idealista poddaje się najczystszemu wyrzeczeniu, trzyma się punktu prometejskiego, który podobnie jak wąska szyjka klepsydry łączy ze sobą dwa królestwa. „Tutaj znajduje się punkt prometejski, który jak przewężenie w klepsydrze łączy dwa królestwa: »Stoję w centralnym punkcie dwóch przeciwstawnych sobie światów, jednego widzialnego, w którym decyduje czyn, drugiego niewidzialnego i zupełnie niepojętego, w którym decyduje wola; dla obu jestem jedną z pierwotnych sił. Moja wola jest tym, co oba te światy obejmuje «"59.

${ }^{59}$ AP I, s. 184. 
Przez wyrzeczenie się siebie idealista nie może uczynić nic innego, jak tylko pozwolić na zaistnienie świata $\mathrm{z}$ wyższego poziomu, to jest życia boskiego. W ten sposób podmiot wydaje się przygotowywać miejsce dla tego, co Absolutne. W rzeczywistości jednak chodzi ciągle o podtrzymanie w transcendentalnym podmiocie postawy, w której zanikanie pojawia się ze względu na nieustanny rozwój. Taki schemat determinuje całe działanie podmiotu, dalekie jednak od postawy radykalnego wyrzeczenia się siebie.

W kwestii doświadczenia estetycznego Balthasar wiąże co prawda pewne nadzieje z myślą Fichtego, ale stopniowo będzie musiał się od niej dystansować. Uważa bowiem, że podmiot dociera do prawdziwego piękna wewnętrznego jedynie wtedy, gdy pozwala się niejako przyciągnąć do miary piękna absolutnego, która przecież jest też jakoś mu udzielana z Absolutu. Podobnie i wolność podmiotu ma najgłębszy dostęp do własnej wewnętrzności, o ile otworzy się na wolność absolutną, która w podmiocie się sama objawia. Filozofia wolności Fichtego jest, zdaniem Balthasara, ciągle wyjaśniana na podstawie kategorii podmiotu transcendentalnego i w ten sposób pozostaje obca religijnemu aktowi rezygnacji z siebie.

\section{Friedrich Wilhelm Joseph Schelling. Ogląd świata i filozofia przyrody}

W innym nieco świetle niż filozofia Fichtego zostają przedstawione przez Balthasara ogląd świata i filozofia przyrody Schellinga. W jego rozważaniach działanie prometejskie nabiera nowego, wydaje się, pełniejszego znaczenia. Jednocześnie znika dualizm kontemplacji i działania, będący u Fichtego podstawowym elementem. Dzięki zwrotowi ku filozofii przyrody i metodzie oglądu intelektualnego Schelling dysponuje jakby szerszym 
rozumieniem świata. Pojęcie mistycznej potencjalności użyte przez Balthasara w stosunku do filozofii Fichtego nabiera pełniejszej postaci, dotyczy już bowiem nie tylko świata podmiotu i relacji człowieka do Boga, ale rozciąga się na naturę.

Filozofia Schellinga w niewielkim stopniu wychodzi poza ramy struktury idealistycznej. Balthasar przywołuje jego myśl, według której filozofia „odczuwa” skłonność „przechodzenia od tego, co jest w stanie pojąć jako konieczne, a co właśnie dlatego nie budzi żadnego podziwu, ku temu, co znajduje się poza i ponad wszelkim pojmowaniem i poznaniem; a nawet nie znajdzie spokoju, zanim nie przedrze się ku temu, co godne absolutnego podziwu (...), co ze swej natury znosi wszelkie dalsze myślenie, ponieważ poza nie wykracza (...). Bóg jest większy, niż myślimy, i nie ma się czego lękać"60. Według Balthasara, myśl Schellinga jest wglądem w prawdziwe tajemnice filozofii, której akt zadziwienia jest aktem pierwotnym. Schelling odpowiada jednocześnie na lęki Jacobiego, który w nauce i racjonalności widział narzędzie eliminacji tego, co godne podziwu. „Podziw może tylko o tyle być nazwanym afektem filozofa, o ile, gdy próbuje namiętnie znaleźć to, co ostateczne, absolutnie zadziwiające, przy spotkaniu z czym zamiera nauka, zaś rozpoczyna się niepojmowana przez Pana niewiedza"61.

\subsection{Odkrywanie Boga}

Schelling widzi rozwój historii w procesie odkrywania żyjącego Boga ${ }^{62}$. Jego koncepcja Boga wpisuje się w charakterystyczną dla całego idealizmu panteistyczną wizję stającego się świata.

${ }^{60}$ Cyt. za: CH III/1/2, s. 508. Omawiając dzieła Schellinga, Balthasar korzysta z wydania: F.W.J Schelling, Sämtliche Werke, hrsg. von K.F.A. Schelling, Stuttgart (Cotta) 1856-1861.

${ }^{61} \mathrm{CH}$ III/1/2, s. 508.

${ }^{62}$ Por. AP I, s. 206. 
Według Balthasara, idealizm Schellinga koncentruje się w dużej mierze na przedstawieniu świata religijnego i jawi się jednocześnie jako „ten, który faktycznie odsłania idealistyczny obraz świata” oraz jako ,prawdziwy teoretyczny eschatolog czasu”63.

W procesie rozwoju świata centralne miejsce zajmuje Bóg głęboko zanurzony w stawaniu się rzeczywistości skończonych. Dynamizm zmiany działający w przyrodzie, głównie w człowieku, otwiera przestrzeń, w której Absolut rozwija się i dąży do swojej głębi. Jednocześnie ,istota człowieka spoczywa wyłącznie w wolności absolutnej, (...) człowiek nie jest rzeczą, przedmiotem, zaś stosownie do swojego własnego bytu nie jest żadnym obiektem" ${ }^{64}$. W ten sposób świadomość zbiega się z bytem. Schelling opowiada się za punktem tożsamości, w którym ,ja (podmiot) ustanawia siebie samego w czynie pierwotnym, a w nim wie o sobie (jako przedmiocie)" ${ }^{65}$. Unoszenie się między działaniem a oddaniem się Absolutowi staje się jednoczącą siłą wyobraźni. Jedność jedności i zróżnicowania pozostanie ostatecznie jednością indyferencji. Według Balthasara, oczywiste jest, że u Schellinga wraz z ,absolutnością myślany i domniemany jest Bóg (»Absolut bądź Bóg«)"66.

Absolut staje się i sam się tworzy, i jako taki objawia się pod postacią bytów skończonych, które pochodzą z jego Bytu i które odnoszą się do niego jako siły jego stawania się. W ten sposób jedność pomiędzy Bogiem i człowiekiem nabiera specyficznego charakteru. Rodzi się pytanie, czy człowiek otwiera się na działanie Boga w pokornym poddaniu się Mu, czy też bosko-ludzka struktura człowieka eliminuje wszelkie koncepcje boskiej przychylności.

\footnotetext{
63 Tamże, s. 205.

${ }^{64}$ Cyt. za: CH III/1/2, s. 507.

65 Tamże.

${ }^{66}$ Cyt. za: tamże.
} 
Badanie filozofii Schellinga w Apokalypse der deutschen Seele Balthasar rozpoczyna od krytycznej analizy oglądu intelektualnego (intellektuale Anschauung). Podobnie jak Fichte, Schelling stawia tezę, że Bóg nie jest przedmiotem należącym do tego świata i nie może zostać sprowadzony do wewnętrznej strony podmiotu. Bóg jest pewnego rodzaju wolnością, która się wydarza. Nie jest ona wolnością ludzką, rozciągającą się w czasie. Bóg, który się wydarza, jest tożsamością, nieustannie uwieczniającą samą siebie, istnieje w swojej ogólności i uniwersalności. Jako taka staje się ona sobą poprzez to, co skończone, a co do niej należy jako siła jej rozwoju. Człowiek jest zatem momentem, za którego pośrednictwem Absolut staje się w świecie rzeczywistości skończonych. Absolut, mimo że „staje się” w podmiocie, ciągle go jednak przewyższa i próbuje nim zawładnąć. W ten sposób absolutna tożsamość wymyka się ludzkiemu rozumieniu, ale jednocześnie sama rozpoznaje siebie we mnie, ja zaś jestem tylko przedmiotem, którym się posługuje, by poznać samą siebie.

Balthasar zauważa, iż ogląd intelektualny Schellinga pokazuje, że jednostka interpretuje samą siebie w świetle Absolutu rozwijającego się własną siłą. Człowiek w świecie skończonych przedmiotów jest wyłącznie ekspresywną figurą Absolutu. Ta wyższość Absolutu pozwala mu beztrosko i spokojnie prowadzić życie w świecie. Inaczej niż w filozofii Fichtego, jednostka jest niejako zwolniona od nieustannego przezwyciężania siebie. Wręcz przeciwnie, może osiągnąć harmonijną równowagę, dając się ponieść strumieniowi życia boskiego, które jednocześnie ożywia i umacnia jej aktywność. Człowiek stanowi część dynamicznego stawania się Absolutu. Cały wszechświat od początku przeznaczony jest do tego, by stanowił miejsce, w którym Bóg poprzez swoją aktywną energię chce stać się sobą poza samym sobą. W ten sposób świat i wszystko, co w nim istnieje, są zewnętrz- 


\section{$128 \quad$ Hans Urs von Balthasar wobec idealizmu niemieckiego}

nym założeniem, możliwym polem działania, które Absolut daje sam sobie, aby móc wypełnić cały swój byt. Bóg jest nieograniczoną siłą bytu, zarówno własnego, jak i wszystkiego, co istnieje poza Nim jako możliwość zaistnienia. Panteistyczna wizja Boga pozwala Schellingowi stwierdzić, że jeśli Bóg rzeczywiście jest Bogiem, musi rozciągnąć swoje działanie i swoją moc także na to, co istnieje poza Nim, i nie może przestać stawać się w świecie. Balthasar stwierdza: „Oto pełna forma mistycznej potencjalności. Wieczne prius (aktualnej) tożsamości w zamkniętym kręgu odwiecznej »konieczności « istoty immanentnie nosi w sobie to, co »przypadkowe«. Bycie istoty Boga - oba te słowa należy ponownie brać jak najbardziej dosłownie - zakłada byt, egzystencję poza tą istotą" ${ }^{67}$. Powołując się na Schellinga, Balthasar kontynuuje: „Praistota jako absolutna tożsamość tego, co realne i idealne, jest sama zakładana znowu tylko subiektywnie, ale równie dobrze musimy ją pojmować obiektywnie: musi być ona absolutną tożsamością tego, co realne i idealne, nie tylko w sobie, ale także poza sobą, to znaczy, że jako taka musi się objawiać, aktualizować - musi ukazywać się również w egzystencji” ${ }^{68}$.

Świat jest zatem pomyślany jako wielość bytów skończonych, w których Absolut nieprzerwanie się staje. Każdy byt zaś jawi się jako możliwość, dzięki której rozprzestrzenia się on i zmierza do swojej pełni w przyrodzie, istotach żywych i w ludzkiej historii. Bóg, realizując siebie samego, wyzwala dynamiczną ewolucję w różnych formach bytu, które są przecież obdarzone zdolnością twórczą. W ten sposób byty stanowią możliwości (Potenzen), w których realizuje się potęga Absolutu. Całość stworzenia stanowi łańcuch ewolucji, począwszy od najniższych warstw materii aż do genialnych wyrażeń ducha w kulturze i historii. Rozwijający się

\footnotetext{
${ }^{67}$ AP I, s. 215.

${ }^{68}$ Cyt. za: tamże.
} 
w świecie duch jest niczym oblicze Boga odbite we wszechświecie, refleks boskości, absolutne niezróżnicowanie, „o ile tkwi ono w odwzorowanym świecie, a jednak równe istocie Boga i do niej podobne, ponieważ w odwzorowanym wszechświecie zawiera się ono nie jako szczególny skutek, lecz jako absolutna tożsamość wszystkich szczególnych skutków z Boga" ${ }^{69}$. Choć fundamentalne dla całego myślenia Schellinga przeciwieństwo tego, co idealne i realne, nie jest według Balthasara ustalone „co do zawartości treściowej"70, to ,ideałem jest to, co powszechne, »kontrakcja jest początkiem wszelkiej realności «: kiedy zatem Bóg z »tego, co powszechne« (bądź ze sfery »bytu«) kurczy się do sfery »bytów«, staje się rzeczywisty, owo kurczenie się jest również jego "przystępnością « od pewnego idealnego »istnienia « do samego założenia, fundamentu bądź bazy, mianowicie »bytu«"71.

Możliwość stworzonego świata istnieje dzięki temu idealnemu istnieniu i otrzymuje możliwość uczestniczenia w bycie Boga, bez utożsamiania z Nim świata. Balthasar za Schellingiem wyciąga wniosek, że „Bóg jako Absolut w tożsamości jest tym, »co nierzeczywiste «, podczas gdy »to, co rzeczywiste, istnieje w nietożsamości tego, co ogólne i szczególne «"72. W ten sposób też „Bóg, aby stawać się istniejącym, potrzebuje świata jako swojej podstawy rzeczywistości, tak że »cały proces stwarzania świata (...) właściwie nie jest niczym innym, jak tylko procesem uświadomienia, postępującej personalizacji Boga «"73.

${ }^{69}$ Tamże, s. 222.

${ }^{70} \mathrm{CH}$ III/1/2, s. 510. Balthasar przywołuje tutaj analogię do Kantowskiego przeciwieństwa między pojęciem i zmysłowością, czy też Husserlowską noezą i noematem. Por. tamże.

71 Tamże.

72 Tamże.

73 Tamże, s. 511. 
Skończony byt w świecie zdaje sobie sprawę, że podążając za twórczym impulsem pochodzącym z wnętrza Absolutu, zmierza do przedstawienia obecności Boga w świecie. Ten, kto przeżywa głęboko jedność z mocą Absolutu, jest jednocześnie najmocniej złączony z uniwersalnym impulsem twórczym i chętnie poddaje się jego działaniu. Balthasar przywołuje słowa Schellinga: „Życie wewnętrzne rzeczy wzmaga się $\mathrm{w}$ relacji do zewnętrznego $\mathrm{w}$ takim stopniu, w jakim ich życie włącza się w centrum lub staje się z nim identyczne. Stąd człowiek, który się w nim znajduje, pozostaje także w najbardziej doskonałej, najbardziej wewnętrznej jedności ze wszystkimi rzeczami: w jedności, która staje się dla niego wiedzą i poznaniem"74.

\subsection{Przestrzeń estetyki}

Takim myśleniem otwiera Schelling przestrzeń ekspresji dla samego bytu, a tym samym dla estetyki, w której forma skończona przedstawia i uobecnia intensywne piękno Absolutu. Balthasar patrzy dosyć przychylnie na myśl Schellinga związaną z rozumieniem piękna, w której podkreśla wzajemne przenikanie się pierwiastka boskiego i ludzkiego. Bóg obejmujący wszechświat wyraża się w postaciach świata ludzkiego, a one z kolei otwierają się na działanie siły boskiej. W ten sposób jednostka otrzymuje własne piękno, które odzwierciedla i wyraża piękno Absolutu, w takim stopniu, w jakim zgadza się być inspirowana do życia przez immanentną działalność twórczą. To właśnie filozofia Schellinga, według Balthasara, najwyraźniej przedstawia ducha estetyki i wyraża go w języku, który stanowi idealistyczną prezentację koncepcji teologii estetycznej ${ }^{75}$.

\footnotetext{
${ }^{74}$ Cyt. za: AP I, s. 223.

${ }^{75}$ Por. CH III/1/2, s. 516.
} 
W kategoriach myślowych idealizmu estetyka nabiera charakteru teologicznego i filozoficznego zarazem. Balthasar pisze: „Estetyczne niezróżnicowanie między nieskończonością i skończonością, między Bogiem, który przejawia się w świecie, światem, który staje się przezroczystym dla Boga, staje się dla Schellinga właściwym kluczem otwierającym wymiar religijny, bowiem różnica $\mathrm{w}$ niezróżnicowaniu pozwala na konstrukcję religii historycznej"76. Balthasar zdaje sobie sprawę, że precyzyjne określenie, jak rozumie się estetykę, pozwala rozróżnić jej znaczenie zarówno w religii, jak i w sztuce i filozofii. Uważa, że „estetyka jako przejawianie się nieskończoności w skończonej postaci (bądź naturze) jest »mitologią «, religią przedchrześcijańską; estetyka jako wyobrażanie skończoności w perspektywie nieskończonej jest »objawieniem ", religią chrześcijańską (i filozofią religijną)"77.

Jeśli jednostka chce być odbiciem Absolutu, musi pozwolić porwać się mocy, która pochodzi z jego wnętrza. Być człowiekiem oznacza: pozwolić ponieść się ku takiemu obrazowi piękna, poprzez który Absolut chce się ukazać. Człowiek niejako zatraca się w tożsamości, by piękno Absolutu mogło się w nim w pełni wyrazić. To zatracenie przywołuje pierwsze pragnienie Schellinga przeprowadzenia obiektywnej metafizyki w nowy idealizm, a tym samym jej zniesienia. Ta obiektywna metafizyka, według niego, zdawała się odnajdywać swój ostateczny kształt w filozofii Spinozy i wyraziła się w, ,identyfikacji z absolutnym przedmiotem oraz zatraceniu siebie $\mathrm{w}$ nieskończoności - w owym amor intellectualis, w którym ja przekracza wszelką granicę siebie samego, aby przyznać absolutowi, Bogu, absolutną przewage" Balthasar ma wątpliwości, czy jednak taka postawa nie oznacza łudzenia samego siebie, bowiem ,jeżeli postrzega siebie samego

\footnotetext{
${ }^{76}$ Tamże.

77 Tamże.

${ }^{78}$ Tamże, s. 508-509.
} 
unicestwionego $\mathrm{w}$ przedmiocie absolutnym, to jednakże siebie samego postrzega, nie mógłby pomyśleć siebie samego jako unicestwionego, nie myśląc siebie równocześnie jako istniejącego" "79. Poświęcenie siebie przedmiotowi jest równocześnie najwyższym posiadaniem siebie. Zdaniem Balthasara, Schelling, zakładając punkt zbieżności podmiotu i przedmiotu, ukazuje zbieżność dwóch ostatecznych postaw egzystencjalnych, w których rozstrzygające słowo ma ja, i wyraża to na sposób mistyczno-eckhartowski: „Tam, gdzie stworzenie samo siebie unicestwi, czyniąc siebie przejrzystym dla stwórcy, tam jest rozum" "80, lub na sposób fichteański: „Tylko w najwyższej wiedzy zamyka się śmiertelne oko, gdzie już nie człowiek widzi, lecz wieczne widzenie stało się w nim widzące"s1.

Balthasar uważa, że rozmyślanie nad kwestią porzucenia wszystkiego prowadzi Schellinga do punktu wyjścia jego filozofii, którym jest niezróżnicowanie (Indifferenz) (podmiotu i przedmiotu). Staje się ono „ową »zapominającą o byciu « jednoznacznością, na której fundamencie można »skonstruować zarówno absolutny, jak i stworzony byt. Zapomnieniem o byciu odznaczała się tradycyjna metafizyka, na ile sądziła, iż niemożliwe jest ustanowienie abstrakcyjnego pojęcia niezależnie od istoty i aktu bytu, od rzeczywistej różnicy między bytem stworzonym oraz tożsamym bytem Boga «"2. Zapomnienie bycia jest dla Schellinga idealizmem, który pojęcie Boga otrzymuje w myśleniu i może go precyzyjnie konstruować, a jednocześnie jest rodzajem ateizmu ${ }^{83}$.

${ }^{79}$ Cyt. za: CH III/1/2, s. 509.

${ }^{80}$ Tamże.

81 Tamże.

82 Tamże, s. 510. Balthasar przywołuje tutaj słowa Emanuela Hirscha, por. E. Hirsch, Geschichte der neuern evangelischen Theologie im Zusammenhang mit den allgemeinen Bewegungen des europäischen Denkens, Bd. 4, C. Bertelsmann, Gütersloh 1952, s. 414.

${ }^{83}$ Por. CH III/1/2, s. 510. 
Zatracanie się człowieka w całkowitej tożsamości, by w ten sposób piękno Absolutu mogło się najpełniej wyrazić w człowieczeństwie, wpisuje się koncepcję Balthasarowskiej estetyki teologicznej. Jednocześnie Balthasar dostrzega jednak fakt, że analogia pomiędzy siłą ekspresji człowieka i mocą boską jest redukowana do pewnego poziomu samodoświadczenia jednostki. Zapewne pozostanie ona $\mathrm{w}$ relacji zgodności z boskim centrum, ale nie ma gwarancji, że oddana w „posłuszeństwie” Absolutowi zrezygnuje z własnego myślenia i działania. Wydaje się, że człowiek schellingowski posłuszny jest przede wszystkim entuzjastycznemu uniesieniu, które porywa jego duszę. Ten „estetyczny entuzjazm, otrzymany z góry i zarazem twórczo wyrastający z głębi własnej duszy, w konsekwencji w systemie czystej potencjalności mistycznej zastępuje pojęcie chrześcijańskiej łaski”" Wewnętrzne uniesienie wydaje się pewnego rodzaju środkiem do wszelkiej relacji z boskością. Tożsamość człowieka z Absolutem wspomaga jego emocjonalny entuzjazm, a boskie piękno jest impulsem, możliwością skupienia się na własnym poczuciu piękna. Tym samym Absolut staje się obecny w świecie poprzez jednostkę i jej przeżycie estetyczne. Balthasar uważa jednak, że obecność samego Absolutu w świecie jednostki służy nie tyle dotarciu do jego piękna, ile temu, by uwydatnić wewnętrzne, entuzjastyczne doświadczenie samej jednostki. W ten sposób rozumienie piękna nabiera charakteru mocno subiektywnego. Potencjalność mistyczna sprowadza się wówczas jedynie do świata idei, namysł człowieka nad pięknem prowadzi do jego bezinteresownej kontemplacji. Można by zatem wysnuć wniosek, że człowiek schellingowski nie interesuje się niczym innym niż własnym entuzjazmem estetycznym i rozumieniem piękna w głębi swojej duszy. To oczywiście skłania go do poszukiwania estetycznych doświadczeń w świecie

${ }^{84}$ AP I, s. 212. 
i życia według nich. „Tylko absolutne jest w Absolutnym (...). To, co szczególne, przez to, iż zostaje rozproszone w nieskończonym wszechbycie, zyskuje tym samym absolutne życie, jest absolutne w samym sobie jednak tylko, o ile jest we wszechświecie, nie może być absolutne i jednocześnie korzystać z życia szczególnego jako szczególnego; również jako szczególne może żyć tylko życiem wszechświata" ${ }^{85}$. Subiektywność przeżywania piękna otwiera człowieka na to, co absolutne, a co jawi się wprawdzie w bezinteresownej kontemplacji, ale prowokuje jednocześnie do nieustannych poszukiwań, by tym samym wznieść się poza bycie w tym, co jedynie szczególne.

\subsection{Tragizm egzystencji}

Krytyczne spojrzenie Balthasara na filozofię Schellinga dotyczy momentu, w którym subiektywne doświadczenie piękna przechodzi od entuzjastycznego uniesienia do przygnębienia i melancholii. Według Balthasara, przejście to ma miejsce, gdy człowiek decyduje się żyć bez poddania się działaniu Boga, w całkowitej koncentracji na samym sobie. Skupiając się na własnym pięknie, odcina się od źródła prawdziwego życia i poddaje zwątpieniu, dryfując w kierunku zagubienia się w rozpaczy. Musimy w tym momencie wrócić ponownie do filozofii Schellinga poświęconej filozofii sztuki.

Estetyczne doświadczenie wprowadza człowieka w entuzjazm wzniosłego przeżycia, pozwala mu przekroczyć ramy czasowości i wznosi go w intensywne doświadczenie nieskończoności ${ }^{86}$. Trwanie podniosłej wzniosłości przeżycia otwiera na

${ }^{85}$ Cyt. za: AP I, s. 229-230.

86 „Jedynie w owym skoku w to, co wieczne, w »świętą otchłań", Schelling pokonuje nerwową klątwę wiecznego zbliżania, która od Leibniza do Kanta i wczesnego Fichtego ciążyła na nowszej eschatologii. W tym, co 
nowe rozumienie piękna. Balthasar wyjaśnia: „Absolutna tożsamość nieskończonego ze skończonym, rozpatrywana obiektywnie i antytypowo, to piękno. Jest więc ona odbiciem jawienia się Boga w czasie. »Zgodnie ze swą naturą, a zatem pośrodku czasu«, jest »wieczna«. Co więcej, tak jak kairos najwyższego oglądu jest jedynie punktowym stykaniem się obu sfer, czasu i wieczności, tak też doskonałe piękno tego, co żyjące, trwa właściwie tylko chwilę, i to tę chwilę próbuje uchwycić sztuka, aby uczynić ją wieczną"87. Sztuka daje możliwość przemiany czasowości w wieczność, a skończony byt musi niejako zapomnieć o sobie, by móc nieść nieskończone życie. Filozofia sztuki Schellinga nawiązuje do greckich ideałów apollińskich, skończona forma zanurza się w nieskończoności uniwersalnej idei.

Sztuka apollińska uznaje za piękną taką figurę, która wykracza poza to, co jednostkowe i ograniczone, zmierzając ku uniwersalnej idei piękna. „Wspaniałością bogów greckich jest to, że w doskonałości indywiduum przedstawiają gatunek, człowieka, i w ten sposób pozwalają podziwiać to, co jednostkowe, a jednocześnie o nim zapomnieć. W doskonały sposób zobrazowany został tutaj eschatologiczny proces »rozpuszczania «. Niesamowicie znamienne dla eschatologii Schellinga jest to, iż w pięknie wdzięku odnajduje najwyższe centrum sztuki, w które jako jego wyższa forma wpisuje się także »wzniosłość« w rozumieniu Kanta i Schillera"88. Schelling postrzega wieczność na podstawie ekstatycznego uniesienia ducha, który wyprowadza poza czasowość i stanowi o intensywnym doświadczeniu nieskończoności. W obecnej u Schellinga apollińskiej tęsknocie za uniwersalnym

wieczne, wszelkie następowanie po sobie jest jednoczesnością, jest też owocem wszelkiej czasowej przyszłości, zagarniętym już w »eonie « wiecznej »przyszłości« Boga"; tamże, s. 232.

${ }^{87}$ Cyt. za: tamże, s. 234.

88 Tamże, s. 235. 
pięknem Balthasar dostrzega przygnębienie dionizyjskiej melancholii. Nieskończoność wiecznego piękna może zostać osiągnięta jedynie w uniesieniu, które jest jednocześnie utratą czasowości.

W perspektywie ekstatycznej wieczności z nieuniknioną koniecznością staje się jasna nietrwałość wszystkiego, z czego jesteśmy wyrywani. Estetyczny entuzjazm uniesienia ujawnia się najmocniej w perspektywie śmierci. Nikt nie jest zdolny do wydobycia piękna bez obowiązku uśmiercenia własnej indywidualności, ponieważ wyrzeczenie się indywidualnego bytu i przemiana w wieczne piękno stanowią dwa aspekty tego samego wydarzenia. Pęd ku wiecznemu pięknu nabiera charakteru dialektycznego. W ogólnej perspektywie jawi się jako dialektyka życia i śmierci, w bliższej zaś jako dialektyka uniesienia i upadku. Upadek jest powrotem do świata skończonego. Wszelkie doświadczenie piękna, nawet najbardziej wzniosłe, niesie ze sobą rozczarowanie. „Tak więc najwyższej szczęśliwości immanentna jest owa melancholia, która uwidacznia się u bogów greckich i która sprawia, że to, co dionizyjskie, wzrasta w tym, co doskonale apollińskie"89. W późnych dziełach Schelling będzie mówił o „słodkiej truciźnie melancholii”, która towarzyszy najwyższej sztuce i będzie rozumiana jako ,jawienie się podwójnego $\delta \iota \alpha$ sytuacji prometejskiej. $\mathrm{W}$ »rozpuszczeniu « bowiem bezpośrednio jednym stają się najwyższe »w sobie« jednostki i najwyższy upadek. »W ten sposób niejako życie i śmierć spotykają się tutaj na szczycie swego zjednoczenia «"

Obecność śmierci w życiu wydobywa na powierzchnię skazanego na nią człowieka, doświadczającego upadku, ale i nadziei na wyzwolenie i odkupienie. Wolność jawi się jako siła, która przez ekstatyczne uniesienie ma pomóc wyrwać się z więzów narzuco-

\footnotetext{
89 Tamże.

90 Tamże, s. 235-236.
} 
nych przez kondycję ludzką. W ten sposób filozofia idealistyczna ukazuje człowieka, który zamyka się w możliwościach własnego myślenia i woli, oddalając się od Absolutu w takim stopniu, w jakim sam dąży do przejęcia kontroli nad własnym losem. Wydaje się, że zarówno Fichte, jak i Schelling „wrzucają” człowieka w jego własną indywidualność, która jednocześnie zaczyna niejako konkurować z samym Absolutem. Ta droga zdaje się jednak skazana na niepowodzenie. Jedynie odrzucenie zarozumiałej afirmacji otwiera na zwycięskie działanie Absolutu.

Schelling, według Balthasara, włącza się w doświadczenie postawy religijnej, oddającej jednostkę w posłuszeństwo mocy Absolutu, postrzeganego jako ten, który staje się sobą poprzez bunt stworzenia. Kontynuując wizję panteistyczną, stawia tezę, że wszystko, co wydarza się w świecie, wydarza się tak naprawdę w Absolucie. Bunt pojawiający się w człowieku jest wydarzeniem, które ma miejsce wewnątrz Absolutu. Historia człowieka i świata jest zbieżna z objawieniem żywego Boga, nieustannie walczącego ze złem w świecie. Schelling nawiązuje do teologii Jakuba Böhmego, u którego Bóg będący żarem miłości musi zdobywać swoją moc w zbuntowanym świecie, pragnącym odłączyć się od Niego.

Balthasar przyznaje, że Schelling na ostatnim etapie swojej działalności wprowadza jakby nowe rozumienie religijnej koncepcji odkupienia. Pojawia się pytanie o grzech i interwencję Boga włączającego się w historię zagubionej ludzkości. Jednak jego rozumienie obce jest myśleniu chrześcijańskiemu, ponieważ zgodnie z duchem dionizyjskim zwraca się przede wszystkim w stronę dramatu wewnętrznego rozdarcia. Odrzuca tym samym koncepcję, że odkupienie pochodzące od Boga musi wyjść poza dialektykę upadku i śmierci. Człowiek nie może zrozumieć samego siebie inaczej jak tylko poprzez egzystencję prowadzącą przez 
śmierć do życia. Jego upadek i słabość stanowią jednocześnie jego wielkość, ponieważ na drodze cierpienia zostaje uniesiony do pełni swojego bytu. Im bardziej Balthasar zagłębia się w tajemnicę kenozy samego Boga, tym bardziej oddala się od dionizyjskiego oczekiwania na zbawienie przez śmierć ${ }^{91}$.

Schelling zdawał sobie sprawę, że tajemnica skończonej wolności ostatecznie nie utożsamia się z wolnością Absolutu. Ludzka wolność jest wprawdzie odbiciem wolności Absolutu, także jej została bowiem dana możliwość determinowania samej siebie, tak jak to czyni sam Absolut, który jest najwyższym sposobem samostanowienia. Ograniczona wolność dąży także do samostanowienia, wybierania siebie, ale w ten sposób działa w jakiś sposób przeciwko Absolutowi. Dążąc do samookreślenia, pragnie koniecznie być równą Bogu. Wpada tym samym w stan zarozumiałego nieposłuszeństwa, który prowadzi ostatecznie do upadku, bycia poza Absolutem. Balthasar pisze: „Wszelka możliwa wolność czy to doczesnego, czy też wiecznego obrazu Boga w momencie jej urzeczywistnienia jest w sposób nieunikniony odstępstwem. Potwierdza się wcześniejsze stwierdzenie, że Schelling rozumie wolność według schematu wolności estetycznej jako demoniczno-nierozstrzygniętą indyferencję między dobrem i złem, ale jej urzeczywistnienie, bycie-dla-siebie (...) może pojąć jedynie przez dokonanie odstępstwa i powrotu" ${ }^{\text {". }}$.

Człowiek znajduje się w przedziwnej sytuacji. Realizując siebie, aktualizuje jednocześnie swoją zdolność do czynienia zła, przechodzi w stan nie-bycia, który oddziela go od Absolutu. W ten sposób Schelling prowadzi do kantowskiej tajemnicy zła

${ }^{91}$ Por. H.U. von Balthasar, Kosmische Liturgie. Höhe und Krise des griechischen Weltbilds bei Maximus Confessor, Herder, Freiburg 1941, s. 108110; tenże, Karl Barth. Darstellung und Deutung seiner Theologie, Hegner, Köln-Olten 1951, s. 71-79.

92 AP I, s. 238. 
radykalnego. W odróżnieniu jednak od filozofii Kanta wydźwięk jego myśli ma wyraźny charakter gnostycki. Człowiek zdaje sobie sprawę, że jego naturą jest widzenie siebie w opozycji do Absolutu, przez co znajdzie się w przestrzeni oddalenia od Boga. Drzemie w nim jednak siła, która pozwala mu nieustannie podnosić się z upadku. Jak już wspomniano, w panteistycznym obrazie świata wszystko, co się wydarza, wydarza się tak naprawdę w Absolucie. Schelling zdaje sobie sprawę, iż jedynym wyjściem w kierunku wyzwolenia człowieka z upadku jest założenie myśli, że w samym Bogu istnieje jakaś mroczna cząstka ograniczenia, zamknięcia, słabości, która jednak w odróżnieniu od bytu skończonego w Nim „całkowicie rozświetlona jest światłem Ducha”93. Bóg jest tym, który pokonał i oczyścił w sobie wszelką ciemność i przemienił ją w światłość, stając się tożsamy z samym sobą. Człowiek unosi się ciągle między ciemnością i światłem, tworząc własną wolność jako „niezróżnicowanie”. Bóg staje się doskonale uporządkowaną miłością, która dostrzega człowieka i w nim kocha cały świat ${ }^{94}$. Ten pozostaje jednak miejscem nieustannej walki harmonijnej miłości i ślepej namiętności, która pragnie oderwać się od uporządkowanej miłości, ponieważ „»W człowieku tkwi cała siła zasady ciemności i właśnie w nim zarazem cała siła światła. W nim są najgłębsza otchłań i najwyższe niebo, albo oba te centra«. On jest niezwykłą równowagą mocy Bożych, prometejskim środkiem świata. On jest »zamkniętym w głębi Bożym spojrzeniem życia (...), jedynie w nim Bóg umiłował świat «"95.

Ostatecznie losy świata leżą w rękach Absolutu, a człowiek podlega dionizyjskiemu tragizmowi, który stawia go w sytuacji rozdarcia, oddzielenia od Boga i oczekiwania na wyzwolenie. Dokona się ono przez działanie Chrystusa, który pokona rozdar-

${ }^{93}$ Cyt. za: tamże, s. 243.

${ }^{94}$ Por. tamże, s. 242.

95 Tamże. 
cie Dionizosa, zajmie miejsce grzesznika i pojedna cały wszechświat z Bogiem, a boskie światło rozproszy wszelki mrok. Co prawda Balthasar zauważa u Schellinga zbliżenie się do objawienia chrześcijańskiego, ale wie, iż jego myśl pozostanie do końca zdominowana przez obce chrześcijaństwu elementy melancholijne i tragiczne. Człowiek będzie w jego filozofii przede wszystkim tym, który cierpi i czuje swoją słabość, ponieważ musi dokonać akceptacji siebie, przeciwstawiając się Absolutowi. Doświadczenie upadku przenika jego życie. Trudno mu zrozumieć konieczność odrzucenia siebie po to, by móc być prowadzonym przez Absolut. Nawet Chrystus nie jest wolny od tego tragicznego przeżycia: On także będzie mógł pojednać Boga ze wszechświatem, wyłącznie odrzucając afirmację samego siebie poprzez bolesne ofiarowanie swego życia.

Człowiek jest wprawdzie otwarty na życie Absolutu w sobie i uzyska w ten sposób wolność, ale będzie ona ograniczona. W momencie kiedy staje się obrazem Boga w świecie, wyrzucany jest niejako poza Niego. Jeśli dąży ku afirmacji siebie, oddalając się tym samym od Boga, to od pierwszych momentów istnienia także jego wolność przyciągana jest przez tajemniczą siłę ku upadkowi. Balthasar przywołuje słowa Schellinga: „Tym, co najciemniejsze i dlatego najgłębsze w naturze ludzkiej, jest tęsknota, niejako wewnętrzna siła ciężkości duszy, zaś w jej najgłębszej postaci melancholia (...). Melancholia jest również tym, co najgłębsze w przyrodzie, ona też opłakuje zagubione dobro; niemożliwa do usunięcia melancholia związana jest także z każdym życiem, bo ma ono pod sobą coś od niego niezależnego"

Człowiek może wyzwolić siebie z melancholii, jeśli pozwoli na unicestwienie wszelkiej dumnej afirmacji siebie i otworzy się na przemieniający wszystko boski ogień. „Zniszczenie wszelkiej

${ }^{96}$ Cyt. za: tamże, s. 248-249. 
możliwości, najwyższy cel każdego dynamicznego działania, zostaje osiągnięte jedynie w wybuchu ognia lub w procesie spalania. (...) »Każdy proces spalania jest złożeniem w ofierze indywidualności «, »rozpuszczeniem tego, co realne, przez to, co idealne«, ale jednocześnie w tym zniszczeniu jego pełnym wyzwoleniem"97. W koncepcji świata charakterystycznej dla Schellinga człowiek prometejski jest nieustannie popychany ku egzystencji tragicznej, która stara się odrodzić w zniszczeniu. W myśl logiki prometejskiej chęć wyzwolenia pozostaje w ten sposób zawsze połączona z pasją jednostki, w swoim pragnieniu skupionej na sobie. Według Balthasara, nie może być mowy o kenozie miłości Boga w kenozie miłości człowieka - a dokładnie Syna człowieczego Jezusa. Dlatego koncepcje Schellinga dotyczące cierpienia, jakkolwiek głębokie by były, nie prowadzą nas do miłości Syna Bożego. Przenikają jedynie do wnętrza uczucia tragizmu, którego człowiek dionizyjski doświadcza w obliczu własnego zniszczenia.

Mistyczna potencjalność, będąca gwarantem dialektycznego ruchu w tym, co absolutne, oraz ku temu, co absolutne, dawała nadzieję na pojednanie człowieka i Boga. Filozofia przyrody Schellinga oznaczała dalszy zwycięski marsz Prometeusza przez naturę. Pozostając ciągle, zdaniem Balthasara, pod „prawem dionizyjskim"98, niósł on ze sobą również symptomy pewnego zakłócenia. Pojawia się miejsce na to, co przypadkowe: „Jakościowa odmienność, odróżniająca to, co idealne, i to, co realne, w obrębie ich samych, ale nie w ich totalności, jest rzeczywiście stanowiona

${ }^{97}$ Cyt. za: tamże, s. 250.

${ }^{98}$ Por. tamże, s. 204nn. Człowiek prometejski jest tutaj najbardziej szczęśliwy i nieszczęśliwy jednocześnie. W swoim rozdarciu znajduje już tylko jedno bóstwo opiekuńcze: Dionizosa. On to mianowicie wypełnia prometejskie zstąpienie na ziemię jako typowy dla natury duch, zmieniający transcendencję w immanencję i tęsknotę w rezygnację. Por. także G. Parotto, Lo sguardo della sibilla. Rivelazione e storia nell'interpretazione balthasariana di Schelling, „Humanitas” 15 (2005), nr 6, s. 1240-1259. 
przez paralelność idealnych i realnych potencji, które z kolei znoszą się w ich totalności. Obie totalności jako jedn a tworzą w ten sposób aktualność formy tożsamości, której tożsamością (...) jest odwieczna żywa idea Boga" ${ }^{99}$. Ogień oświecenia przyniesiony przez bohatera Schellinga jest co prawda ogniem przemieniającym wszystko, ale jako taki nie jest jeszcze realny. „Bóg to dla niego [Schellinga - M.U.] wprawdzie »wyniszczająca ostrość« czystej światłości, ale właśnie dlatego nie jest jeszcze realny"100.

Balthasar zauważa u Schellinga jeszcze jeden decydujący brak: $\mathrm{w}$ zasadniczym nurcie swojej filozofii pozostaje on panteista, zwolennikiem idei jedności wszystkiego. Jego zwrot ku chrześcijaństwu wydaje się Balthasarowi niemożliwy. „Duch-natura-miłość jako rzeczy ostateczne to znak Dionizosa. Jest to także znak Schellinga. Jego ogromne późne dzieło Filozofia mitologii i objawienia, chociaż bardzo stara się włączyć całe chrześcijaństwo w to, co gnostyczne, również stoi pod tym znakiem, który swą wyrazistość już wcześniej przecież zawdzięczał właśnie owe$\mathrm{mu} »$ włączeniu «"

Czy jednak rzeczywiście Schelling jest wyznawcą naiwnego panteizmu, jak będzie to widział także Hegel $^{102}$ ?

${ }^{99}$ AP I, s. 215.

100 Tamże, s. 250.

101 Tamże, s. 246. W przypisie Balthasar dodaje: „Dlatego też możemy zrezygnować tutaj z przedstawienia tego późnego dzieła, tym bardziej że nie wywarło ono już istotnego wpływu na dzieje najnowsze"; tamże.

102 Schellingiański spinozyzm, panteizm od samego początku zgodny jest z linią teistycznie interpretowanego spinozyzmu Mendelssohna, Herdera i Goethego. Zasada jedności i powszechności oraz wynikająca z jej dynamizacji i objaśnienia zasada triady są dla Schellinga podstawą religii w ogóle, powszechnie obowiązującym punktem wyjścia do samoobjawienia się Boga, które niejako wyłania się z religii przyrody i mitologii. Za ostatnie i najbardziej rozwinięte ogniwo tego objawienia Schelling uważa chrześcijaństwo; por. M. Bondeli, Mystische Potentialität, dz. cyt., s. 152. 


\section{Georg Wilhelm Friedrich Hegel. Refleksja filozoficzna}

Hegel jest dla Balthasara filozofem, który kończy bogatą myśl nowożytną. Według Petera Henriciego, kuzyna szwajcarskiego myśliciela, „od swego pierwszego do ostatniego dzieła Balthasar snuje swą myśl oko w oko z Heglem. (...) U Hegla, a więc w okresie postchrześcijańskim, nie ma już nierozstrzygniętej otwartości, lecz to, co chrześcijańskie, zostaje wyraźnie przejęte przez filozofię"

Dlaczego akurat Hegel jest tym, którego myśl można odnaleźć w większości dzieł Balthasara? Wydaje się słusznym spostrzeżenie Michaela Schulza, że odpowiedź na to pytanie można sformułować na dwa sposoby: „Starogrecka reguła dotycząca poznania mówi, że podobne poznawane jest tylko przez podobne. Czy zatem Balthasar rozpoznaje w Heglu myślenie podobne do swego własnego? Czy też to, co podobne, zostaje raczej ukazane przez to, co w nim inne, sub contrario? Tylko czym w takim razie byłoby to inne? Tym, co podobne, co łączy Hegla i Balthasara, jest trynitarna prawda chrześcijaństwa. Jednak to, co wspólne, zostaje opisane z dwóch całkowicie przeciwnych perspektyw. Balthasar wybiera perspektywę miłości, Hegel - perspektywę rozumu, rozumu przebiegłego, jak dodaje Balthasar, cytując Hegla"104.

Różne perspektywy prowadzą zapewne do różnych relacji między treścią i formą rozważanej myśli. Różne perspektywy mogą też znacząco zmienić samą treść, trynitarną prawdę chrześcijaństwa, a wtedy może się okazać, że wspólne myślenie Hegla

${ }^{103}$ P. Henrici, O filozofii Hansa Ursa von Balthasara, w: PW 1, s. 164.

${ }^{104}$ M. Schulz, Die Logik der Liebe und die List der Vernunft. Hans Urs von Balthasar und Georg Wilhelm Friedrich Hegel, w: Logik der Liebe und Herrlichkeit Gottes. Hans Urs von Balthasar im Gespräch. Festgabe für Karl Kardinal Lehmann zum 70. Geburtstag, hrsg. von W. Kasper, Matthias Grünewald Verlag, Ostfildern 2006, s. 111. 


\section{$144 \quad$ Hans Urs von Balthasar wobec idealizmu niemieckiego}

i Balthasara jest tylko pozornym podobieństwem. W takim wypadku dystansowanie się Balthasara od Hegla musiałoby przyjąć świadomie formę oddalania się od jego myślenia, z zachowaniem jednak pewnych punktów stycznych, ponieważ skrajności też zdają się być zbieżne ${ }^{105}$. Balthasar zarówno zauważa odkrycie młodego Hegla, że życie i miłość należy rozumieć jako postacie tworzące jedność pokonującą wszelkie sprzeczności, jak też aprobuje jego próbę ratowania chrześcijańskiej prawdy o Trójcy Świętej. Według niego, Hegel podejmuje ją w swojej metafizyce miłości, jak i w poszukiwaniach fundamentów ontologii miłości bytu. Rozwija prawdę o tym, że bycie osobą wypełnia się dopiero w miłości, w tym drugim. Dlatego też mówienie o trzech Osobach nie odnosi się do trzech wyizolowanych indywiduów, nie do trzech bogów, lecz do jednego Boga, który jest Miłością. Miłość zaś może być rzeczywista tylko jako osobowe wydarzenie jedności i różnicy, wydarzenie bycia sobą jako bycie w drugim.

W Apokalypse Balthasar stwierdzi, iż cały świat Hegla streszcza się całkowicie w tajemnicy miłości, która staje się eschatonem, a więc tym, co ostateczne. Miłość jest w myśleniu Hegla w oczywisty sposób postawą ostateczną, zgodnie z którą wszelki byt należy opisywać jako miłośćci ${ }^{106}$. Nie ulega wątpliwości, że Balthasar, podkreślając jego rozważania na temat miłości, wskazuje również inną, nową perspektywę, która u Hegla przewyższy ostatecznie świat miłości, a mianowicie perspektywę przebiegłego rozumu. Balthasar przyjmuje wprawdzie Heglowską filozofię rozumu, o ile w warunkach czasów nowożytnych aktualizuje ona klasyczną tezę inteligibilności i prawdy wszelkiego bytu. Oczywiste jest również, że miłość pozbawiona prawdy, a więc nieprawdziwa lub nierozsądna, stanowi sprzeczność samą w sobie. Jednak, zda-

105 Por. tamże, s. 112.

${ }^{106}$ Por. AP I, s. 582, 606. 
niem Balthasara, w myśleniu Hegla powoli zarysowuje się pewien zwrot. Trynitarna prawda jawi się jako ,idea i prawda wszelkiego bytu w Bogu i poza Nim"107. W ten sposób pojawia się przezwyciężające myślenie ${ }^{108}$, wyrastające z roszczeń systemowego patrzenia na rzeczywistość, które zmierza do dedukcji z pojęcia absolutu wszystkiego, co konieczne i rzeczywiste. Przy tej dedukcji istota miłości, jej odwieczność i niepochodność jako wydarzenia wolności, a wobec tego misterium tego, co osobowe, giną na rzecz miłości, która ,jako taka zostaje zlogicyzowana (logisiert)"109.

Pojęcie rozumu rozwinięte przez Hegla pozbawiło ofiarę miłości, wprowadziło wyrachowanie, które przedstawia się jako zręcz-

107 Tamże, s. 587.

108 „Myślenie przezwyciężające jest bezsilne wobec tajemnic filozoficznych. Jego rozwiązanie brzmi: divide et impera - rozdziel tajemnicę rzeczywistości na dwoje; tu to, czego »o Bogu można się dowiedzieć« (gnoston tou Theon; Rz 1, 19), co da się zrozumieć i co można sobie przyswoić - tam to, »czego nie można poznać« (aorata; Rz 1, 20), do czego brakuje nam odpowiednich organów, co nas w konsekwencji też wcale nie obchodzi. Z tego powodu kierunek nowoczesnego myślenia jest podwójny: najpierw tak przybliżyć Boga ludziom, aby to, co On przynosi, mogło być zasymilowane; następnie Boga tak oddalić, aby to, czego nie można poznać, człowieka wcale już nie obchodziło. Jedno i drugie może być realizowane zarówno pod szyldem chrześcijańskim, jak i ateistycznym: przybliżając Boga, traktuje się tajemnicę wcielenia z powagą, oddalając Boga, okazuje się Mu prawdziwą bojaźń, dzięki której nie myli się Go z bałwochwalczymi obrazami ludzkiego rozumu. Tak jest po chrześcijańsku. A tak po ateistycznemu: Boga trzeba tak bardzo przybliżać, aż zrównany zostanie z człowiekiem, i tak bardzo oddalać, aż rozpłynie się w nicości"; H.U. von Balthasar, Cordula albo o świadectwie chrześcijanina, tłum. F. Wycisk, WAM, Kraków 2002, s. 58.

${ }^{109}$ Por. M. Schulz, Die Logik der Liebe und die List der Vernunft, dz. cyt., s. 122. „»Pozytywność nie ma dla Hegla sensu sama w sobie, lecz jest po prostu odniesiona do negatywności« i odwrotnie (...), ale zapewne tylko dlatego, że przechodzenie do drugiego jest zawsze rozumiane jako wyobcowanie, a nie jako miłość (czy miłująca kenoza), że zatem miłość jako taka zostaje udostępniona poznaniu, a w końcu w absolutnej wiedzy całkowicie znika”; TL II, s. 44. 


\section{$146 \quad$ Hans Urs von Balthasar wobec idealizmu niemieckiego}

ność spekulatywnego myślenia. Miłość i ofiara zostają wprzężone $\mathrm{w}$ dobrowolnie przyjętą celowość ogarniającego wszystko rozumu, a „istotą ducha jest zdobywanie siebie przez poświęcenie"110. Heglowska wiedza stoi ponad ofiarującą siebie miłością. Balthasar docenia zatem odkrycie młodego Hegla, że życie i miłość należy rozumieć jako jednostkowe postacie przezwyciężające każde przeciwieństwo i usuwające filozoficzne dualizmy Kanta, ale stwierdza jednoznacznie, że Hegel mimo romantycznych korzeni swej myśli nigdy nie stał się ani prawdziwym filozofem życia, ani filozofem miłości ${ }^{111}$.

\subsection{Hegel i kultura europejska}

Zanim spróbujemy prześledzić drogę wskazaną przez Hegla, warto wspomnieć, że Balthasar umieszcza jego filozofię w kontekście całej kultury europejskiej, w której widział zagrożenie dla właściwego patrzenia na człowieka. W tekście z 1948 roku zatytułowanym Humanizm chrześcijański stwierdzał: „Nie będzie to chyba zbyt śmiałe, jeśli odważymy się powiedzieć: ostateczne zagrożenie zachodniego humanizmu bierze się z pojęcia Boga, pojęcia, które jako pusta nieskończoność jest przeciwieństwem wypełnionej skończoności świata, dlatego rozsadza jego wymiary stworzenia i zbija z tropu zajmującego się Bogiem człowieka"112.

Problem ten istniał w myśli europejskiej, jeszcze zanim pojawił się w filozofii Hegla: „Tak było już w gnozie, w różnych formach mistyki hellenistycznej, w którą wplatają się, co znamienne, obce Zachodowi, wschodnie motywy. Tak było też w całej pochodzącej od niej mistyce aż po Böhmego i idealistów, po dialektykę Hegla, w której pomimo nadludzkich starań abstrakcyjne bycie naprze-

\footnotetext{
110 AP I, s. 609.

${ }^{111}$ Por. tamże, s. 566.

${ }^{112}$ H.U. von Balthasar, Humanizm chrześcijański, w: PW 1, s. 89.
} 
ciw siebie skończoności i nieskończoności nie osiąga pojednania" ${ }^{113}$. Pewnym rozwiązaniem wydawała się myśl o charakterze antropologicznym, szukająca właśnie w człowieku usunięcia napięcia pomiędzy skończonością i nieskończonością. Z jednej strony pozostawał dystans między Bogiem i człowiekiem, z drugiej pojawiała się konieczność skrócenia tegoż dystansu w myślącym podmiocie, który niejako intuicyjnie dążył do wdarcia się w świat przekraczający swoje możliwości. Balthasar był przekonany, że „we wszystkich tych formach dystansu między Bogiem i człowiekiem nie da się inaczej pokonać niż w myśli o bezpośrednim, nawet jeśli może nigdy nie osiągniętym, może tylko asymptotycznie zamierzonym przebóstwieniu człowieka, które jednak jako warunek zakłada jego »od-graniczenie« i »od-człowieczenie «"114.

Takie patrzenie rodziło jednak niebezpieczeństwo odwrócenia zamierzonych celów. Zamiast wpatrywać się w świat przekraczający wszelkie ograniczenie, człowiek stawał przed możliwością odkrywania samego siebie, ale czynił to w duchu, który ukazywał tragiczne i „demoniczne” jego strony. W ten sposób „wbrew wszystkiemu, co wcześniej zostało powiedziane, „tytanizm” burzący granice humanum byłby więc wówczas zakorzeniony w nim samym, a przez to odsłonięte zostałyby tragizm, demonizm $\mathrm{i} »$ niebezpieczność « człowieka, jaką przedstawiono w Fauście, stanowiącym jednak tylko przykład całej dialektyki mistyczno-ateistycznej i sztandarowej problematyki humanizmu opierającego się na sobie samym i sobie samemu wystarczającego"115.

Balthasar zastanawia się w tym miejscu nad dalszymi drogami zrozumienia owego dystansu między Bogiem i człowiekiem. Pójście za myślą Hegla prowadzi go do religii judaistycznej lub do zsekularyzowanej myśli spirytualistycznej i panteistycznej. „Czy

113 Tamże.

114 Tamże.

115 Tamże. 
powinno się dalej (za Heglem) powiedzieć, że to samo nagie bycie naprzeciw siebie skończoności i nieskończoności leżało także u podstaw judaizmu i że zatem nie mogło ono doprowadzić do ostatecznego zakotwiczenia humanizmu w tym, co wieczne, tam, gdzie został zachowany w swej czystości element żydowski lub gdzie - jak to często bywało - wymieszał się on $\mathrm{z}$ formami helleńskimi?""116. Zsekularyzowanie myśli chrześcijańskiej otwierało jednocześnie bramy temu, co nieuporządkowane i tragiczne. Balthasar pisze dalej: „Albo Bóg, aby być »znośnym «, musiał, jak u Spinozy i Bergsona, zostać zeświecczonym, albo człowiek potajemnie lub jawnie przebóstwionym, jak to ma miejsce w większości form mistyki żydowskiej, dzięki czemu otworzyły się znowu na oścież wszystkie drzwi tego, co tragiczno-demoniczne"117.

\subsection{W opozycji do Fichtego i Schellinga}

Schellingowskie pojmowanie objawienia jako najwyższej formy mitu uważa Balthasar za dzieło niedokończone, które dopełni dopiero Hegel. Przeprowadzi on wiarę chrześcijańską w ostateczne zrozumienie, będące syntezą całej religijnej przeszłości świata i jednocześnie wskazaniem drogi ku przyszłości ${ }^{118}$.

Myślowa droga Hegla przebiega zatem w opozycji do Fichtego i Schellinga, którzy swoje filozofie opierali przede wszystkim na zasadzie tożsamości, ,wychodząc stopniowo poza jej wkład, powrócili do chrześcijaństwa naznaczonego Ewangelią św. Jana (...), Hegel we wczesnym okresie swej twórczości długo zmagał się z Chrystusem, sensem jego życia oraz tym, co po sobie zostawił, aby następnie wyraźnie zdecydować, co można z tego materiału

116 Tamże, s. 90.

117 Tamże.

118 „Hegel ma świadomość pełnomocnictwa otrzymanego od ducha świata celem odsłonięcia przyszłości”; CH III/1/2, s. 521. 
zużytkować filozoficznie oraz wcielić w jego system, co zaś jako niestrawną resztę odrzucić”119.

Napięcie pomiędzy filozoficznym systemem Hegla a chrześcijaństwem Balthasar streścił następująco: „Ideałem idealisty jest prześwietlenie siebie aż do krystalicznego świata konieczności, idei. Ideałem chrześcijanina jest odwrotne zachowanie: nie zważać na siebie, zapatrzeć się w Boga. Na tej drodze Bóg nie oszczędzi mu z pewnością wejrzenia w samego siebie, ale będzie to także przeciwieństwem idealistycznej refleksji. Demoniczność Hegla polega na tym, że próbował on zrównać bądź wykorzystać myśl chrześcijańską w refleksji filozoficznej" ${ }^{120}$. Czy rzeczywiście takie wykorzystanie myśli chrześcijańskiej ma charakter jedynie negatywny? Pytanie to wpisuje się w ciągle żywą debatę nad stanem „filozofii chrześcijańskiej”. Balthasar chce przede wszystkim uprawiać filozofię w przestrzeni myślenia chrześcijańskiego. Być może owa „demoniczność” Hegla nie ma aż tak głębokiego uzasadnienia i zostanie przez niego samego nieco osłabiona.

Balthasar nakreślił kierunki badań nad filozofią Hegla w następujący sposób: „Można próbować zsekularyzować elementy chrześcijańskie, które przeniknęły do filozofii, »rozpuścić« je w filozofii: to wielka próba Hegla, który robi zwrot od liberalnie rozumianego chrześcijaństwa Janowego ku ogólnej logizacji miłości”"121. Można także podjąć próbę całkowitego wbudowania wiary w system, który „w ten sposób ustanawia się wobec wiary tym, czym jest rzecz ostatnia wobec przedostatniej"122. Według Petera Henriciego, Balthasar, nawiązując do Plotyna, był przekonany, że postplatońska linia rozstrzygnięć prowadzi przez

119 Tamże.

${ }^{120}$ H.U. von Balthasar, Ziarno pszenicy. Aforyzmy, tłum. J. Ryndak, Wydawnictwo M, Kraków 2004, s. 140-141.

${ }^{121}$ Tenże, Ewangelia i filozofia, w: PW 1, s. 74.

122 OZFK, s. 41. 
Fichtego i Schellinga prosto do Hegla i w filozofii „wiedzy absolutnej" znajduje swe niedościgłe zwieńczenie ${ }^{123}$.

Balthasar dostrzega nowy kierunek myślenia Hegla, przywołując jego przyjaciela z młodości, Hölderlina, który „,był blisko owego zwrotu Hegla około roku 1800: hasło brzmi hen kai pan (jedno i wszystko): zamiast jak u Fichtego i Schellinga uparcie trwać jak zmrożony na stanowisku tożsamości, »jedno « rozpływa się we »wszystkim ", ukazując się w nim jako miłość-pełnia (pleroma) oraz znajdująca się w potrzebie nędza (penia, kenosis) jednocześnie, aby zwycięsko powrócić z całą swoją rozwiniętą prawdą i przepychem w jedyne jedno. Jak u Hölderlina, tak u Hegla chrześcijaństwo zniesie się w momencie wszechobecnej kenozy bytu, w której dla obu wydarzy się niedościgniona »wspaniałość« rzeczywistości” ${ }^{124}$. Ta wspaniałość rzeczywistości zmierzać będzie nieuchronnie ku zrównaniu jej z totalnością ducha absolutnego, będącego istotą zarówno filozofii, jak i religii. W ten sposób Hegel jest dla Balthasara ,zamknięciem wyjaśniania świata, które kosmos rozumie jako wykładnię Boga: stoików, Plotyna, Pseudo-Dionizego, Eriugeny, Kuzańczyka, Ficino, Spinozy, Herdera, Goethego" "125. Mówiąc słowami Hegla z Wykładów z filozofii religii: „Przedmiotem zarówno religii, jak i filozofii jest sama wieczna prawda w swojej obiektywności - Bóg i nic poza Bogiem i eksplikacją Boga. Filozofia nie jest mądrością tego świata, lecz jest poznaniem tego, co nie jest z tego świata"126.

${ }^{123}$ Por. P. Henrici, O filozofii Hansa Ursa von Balthasara, dz. cyt., s. 163.

${ }^{124} \mathrm{CH}$ III/1/2, s. 522.

125 Tamże.

${ }^{126}$ G.W.F. Hegel, Wykłady z filozofii religii, t. 1, tłum. Ś.F. Nowicki, Wydawnictwo Naukowe PWN, Warszawa 2006, s. 21. 


\subsection{Podmiot i przedmiot}

Balthasar wykazuje zatem początkowo, że filozofia Hegla próbuje w tym, co obiektywne, przezwyciężyć rozróżnienie podmiotu i przedmiotu, które przez Kartezjusza przenika z filozofii greckiej do zachodniej. Dla Hegla „prawda jest całością. Całością zaś jest tylko taka istota, która dzięki swemu rozwojowi dochodzi do swego ostatecznego zakończenia"127. W takim rozumieniu poznanie ma charakter przede wszystkim przedmiotowy i koniecznościowy i zmierza do zniesienia dialektycznego przeciwieństwa podmiotu i przedmiotu, kierując się tym samym ku jedności i całości. Według Hegla, „naukowe poznanie wymaga jednak raczej tego, by oddać się całkowicie życiu przedmiotu, albo - co na jedno wychodzi - wymaga tego, by mieć przed oczyma jego wewnętrzną konieczność i konieczność tę wyrazić. Wgłębiając się w swój przedmiot, zapomina naukowe poznanie o [dokonywanym przez rozsądek] przeglądzie całości, przeglądzie, który jest tylko refleksyjnym skierowaniem się wiedzy od treści ku sobie samej"128.

Ostatecznie wyzwanie jedności sprawia, że myśl Heglowska utożsamia treści poznania naukowego z poszukiwaniem najwyższej prawdy o rzeczywistości, która przepełniona racjonalnością nabiera charakteru boskiego. Dlatego też ,poznanie naukowe, zatapiając się w materii i idąc za jej ruchem, wraca wprawdzie także do siebie, ale nie wcześniej, aż wypełnienie, czyli sama treść, wycofując się z powrotem do siebie, nie uprości się w określoność, nie zdegraduje siebie samej do tego, by okazać się tylko jaką́s stroną istnienia, i sama nie przejdzie w swoją wyższą prawdę. W ten sposób prosta całość, będąca zarazem pewnym przeglądem (das ein-

127 Tenże, Fenomenologia ducha, tłum. A. Landman, PWN, Warszawa 1963, s. 28.

${ }^{128}$ Tamże, s. 69. 
fache sich übersehende Ganze), wyłania się sama z tego bogactwa [treści], w którym jej refleksja wydawała się zagubiona"129.

Tę dialektyczną strukturę heglowską Balthasar umieszcza na drodze zjednoczenia tego, co subiektywne i obiektywne, tego, co jednostkowe i uniwersalne. Podmiot, który uważa się za rozum prawodawczy, dzięki refleksji nad samym sobą może potwierdzać sądy aprioryczne i aposterioryczne w swoim własnym działaniu i poszukiwać ,albo ostatecznego upewnienia w archetypicznie ustanawiającym rozumie, w którym posiada udział, a którym jest Bóg (Kartezjusz), albo uczestnictwo to pojmować jako ostateczną tożsamość skończonego i nieskończonego podmiotu i wraz z nim projektować realne istoty, wyłaniając je z siebie: statycznie (u Spinozy) bądź dynamicznie (u Leibniza i Fichtego), lub też na oba sposoby (u Hegla)"130. To samo dokona się w działaniu heglowskiego ducha absolutnego. W heglowskiej dialektyce ducha ukazują się wszelkie zróżnicowania, które ostatecznie tworzą jedność i całość historii. W ten sposób, według Balthasara, Hegel krytykuje radykalnie pojęcie kantowskiego noumenu. Chcąc doprowadzić wszystko do jedności, wzmacnia niejako zapomnienie różnicy ontologicznej, która była u początku myślenia zachodniego. Rzeczywistość jest redukowalna do jedności, jeśli nawet w rozwoju dialektycznym pojawia się widoczna odrębność. Balthasar stwierdza jednoznacznie, że w myśli Heglowskiej „wzajemne dążenie do siebie jedności i wielości jest tak bardzo tym, co pierwsze w byciu i myśleniu, że rozdwojenie się (jawienie się) jako takie jest już zniesieniem przeciwstawności (skończone-nieskończone)"131.

129 Tamże, s. 69-70.

${ }^{130} \mathrm{CH} \mathrm{III/1/2,} \mathrm{s.} 24$.

131 AP I, s. 578-579. „I dlatego też rozdwojenie się tego, co równa się samemu sobie, oznacza także znoszenie siebie jako czegoś już rozdwojonego, oznacza, że to, co jest równe samemu sobie, znosi siebie jako innobyt”: G.W.F. Hegel, Fenomenologia ducha, dz. cyt., s. 190. 
Jedność, o której mówi Hegel w Fenomenologii ducha, nie jest jednością wyizolowaną z wielości, jak chciał Schelling, ale „w istocie rzeczy tylko jednym $\mathrm{z}$ momentów rozdwojenia; jest abstrakcją prostej niezłożoności, będącej przeciwstawieniem różnicy. Ale, jeśli uważamy, że jedność jest abstrakcją, że jest tylko jednym członem przeciwstawności, to stwierdzamy tym samym, że jest ona rozdwajaniem. Jeśli bowiem ta jedność jest czymś negatywnym, czymś przeciwstawnym, to została ona założona właśnie jako coś, co w sobie samym zawiera przeciwstawność. Toteż różnica między rozdwajaniem się i stawaniem się równym samemu sobie jest również tylko ruchem znoszenia samego siebie" 132 .

Hegel wybrał drogę, którą Balthasar opisuje jako metafizykę miłości. Miłość jest „dokonaniem się nowego wymiaru ducha, wymiaru, w którym jawi się on sobie rzeczywiście jako inny, tożsamość rozciąga się ponad najbardziej niezgłębione wyobcowanie - jest prawdą samego myślenia"133. To nowe prawo określające przestrzeń działania ducha. Coś jest tym bardziej dla siebie, im bardziej się otwiera i obejmuje to, co znajduje się niejako przed nim.

Balthasar wydaje się naśladować Hegla, analizując dwie formy, których nie obejmuje prawo miłości. Pierwszą jest indywidualizm przyjemności, drugą - liberalizm sentymentalny. Jednostkowa indywidualność szukała najpierw przyjemności w świecie, natrafiała jednak na nieprzezwyciężalną konieczność i obecność drugiego. Próbowała także odnaleźć się w świecie i kształtować go według prawa serca, lecz spotykała się z oporem innych indywidualności, dlatego też jej zamiar aktualizował się w sposób zniekształcony i współpracował niejako z biegiem świata, niezdominowanego

\footnotetext{
132 Tamże, s. $190-191$.

133 AP I, s. 580.
} 


\section{$154 \quad$ Hans Urs von Balthasar wobec idealizmu niemieckiego}

przez pozytywność i czystość chcianego dobra uniwersalnego. Bieg świata jawi się przede wszystkim jako owoc różnych indywidualności, ich przyjemności i egoizmów.

Formom indywidualności przeciwstawia Hegel cnotę i jej dialektykę, która idąc za chęcią odnowienia porządku idealnego w świecie, oznacza złożenie ofiary z indywidualności. Ostatecznie przecież ruch indywidualności zmierza do rzeczywistości tego, co uniwersalne. „Jako zawarta w samej świadomości cnotliwej ogólność jest celem, jako zawarta w biegu spraw świata - jest czymś wewnętrznym. Dla biegu spraw świata ogólność zawarta w cnocie ma także charakter właśnie czegoś wewnętrznego. Cnota bowiem dopiero chce spełnić dobro i sama nie traktuje go jeszcze jako czegoś rzeczywistego"134.

Wydaje się, że Balthasar chce ukazać Heglowską próbę wyjścia jednostkowej świadomości ze swego rzekomego, abstrakcyjnego odosobnienia i wzniesienia się na poziom ducha, czyli przedstawić wysiłek dialektyki, która indywidualnej świadomości odsłania jej relację ontologiczną z innymi bytami. Ruch dialektyczny dokonuje się od substancji do podmiotu, od ducha, który istnieje w sposób prosty, do samoświadomości ducha. Ostatecznie absolut jest podmiotem ${ }^{135}$. Poznanie intelektu jest myśleniem absolutu. Trynitarna miłość staje się prawdą świata. Omawiając problem rodziny, Hegel stwierdza: „Miłość oznacza w ogóle świadomość mojej jedności z kimś drugim, tak że nie istnieję w sposób odizolowany dla siebie, lecz swoją samoświadomość uzyskuję tylko jako anulowanie mego bycia dla siebie i przez wiedzę o sobie jako jedności siebie z kimś drugim i tego drugiego ze mną... Pierwszym momentem w miłości jest to, że nie chcę być samoistną osobą dla siebie i że gdybym nią był, czułbym się istotą, której czegoś brak,

${ }^{134}$ G.W.F. Hegel, Fenomenologia ducha, dz. cyt., s. 429; por. także s. 413426.

${ }^{135}$ Por. tamże, s. 31. 
która jest niepełna. Drugim momentem jest to, że uzyskuję siebie $\mathrm{w}$ innej osobie, że coś w niej znaczę, co z kolei ona osiąga we mnie. Miłość jest więc najbardziej niesłychaną sprzecznością, której rozsądek nie może rozwiązać, jako że nie ma nic trudniejszego niż ta punktowość samoświadomości, która zostaje zanegowana, a którą jednak mam mieć jako afirmatywną. Miłość jest wytwarzaniem tej sprzeczności i zarazem jej rozwiązaniem"136.

W rzeczywistości heglowska logika potrafi wyjaśnić wszelką różnicę, także tę między tym, co skończone i nieskończone, ale za cenę zredukowania tego, co nieskończone, do samej logiki. Jeśli element trynitarny ukazuje się jako idea i prawda wszelkiego bytu w Bogu i poza Bogiem, to Hegel eliminuje różnicę pomiędzy Trójcą a stworzeniem. Balthasar stwierdza: „Hegel nie drogą mistyczną, lecz czysto logiczną uczyni to tak, że tajemnica miłości Trójcy, obejmujące Boga i świat prawo samoruchu pojęcia tezy i antytezy staje się prawdą (tożsamości tożsamości i nietożsamości)"137. Jeśli jednak to, co nieskończone (Absolut), potrzebuje skończonego świata dla doskonalenia siebie i aktualizacji swoich możliwości, a nawet potrzebuje świata jako przedmiotu swojej miłości, to czy czasem sam nie staje się skończony? Wydaje się, że Balthasar dostrzega u Hegla pewną próbę przezwyciężenia panteistycznej wizji zredukowania wszystkiego do jedności. Przezwyciężenie to ukazuje się w transpozycji (przestawieniu) głębokiego doświadczenia ludzkiego i egzystencjalnego miłości. W młodzieńczych pismach Hegla można zauważyć oznaki ujęcia doświadczenia miłości ludzkiej jako miłości boskiej, która stała się podstawą myślenia dialektycznego. Balthasar jest jednak w tym miejscu mocno sceptyczny wobec zamiaru Hegla. Sądzi bowiem, że ten „,wierzył przez długi czas, że boskie życie i jego wykładnię w świecie można

\footnotetext{
${ }^{136}$ Cyt. za: TL II, s. 42.

137 Tamże, s. 306, przyp. 32.
} 
wyjaśnić, posługując się miłością jako pojęciem wiodącym; jednakże w końcu pojęcie to zanika wstydliwie we wnętrzu wiedzy absolutnej, aby jeszcze tylko panować jako wzlot i blask jego ruchu »bachantek «, w którym »nie ma ani jednego członka, który by nie był upojony «"138.

Hegel zdawał sobie sprawę, że boskości nie można zrozumieć na sposób przedmiotowy i obiektywny, jak chciał Fichte. Każdy sąd o tym, co boskie, wyrażony w formie refleksyjnej jest niedorzeczny. Dlatego też Bóg staje się dla Hegla „czystą wieczną miłością, światłem, życiem; stąd jest absolutną siłą jednoczącą, znoszącą wszelkie rozdzielenie (które jest założone)"139. Ponieważ miłość jest siłą jednoczącą, znosi wszelki podział i złożoność. Rzeczywistość otrzymuje w niej charakter nieskończony, uzyskuje prawdę o jedności i całości dzięki działaniu Boga. „W miłości człowiek odnalazł siebie samego w kimś innym; ponieważ miłość jest zjednoczeniem życia, przeto zakłada rozdzielenie, rozwój, wykształconą wielostronność życia; a w im liczniejszych formach życie jest żywe, w tym liczniejszych punktach może siebie jednoczyć i odczuwać; tym głębsza może być miłość”140. W późniejszych pismach Hegel będzie rozumiał prawdę jako rzeczywistość przewyższającą czysty intelekt, w której żywy rozum nosi w sobie żywioł miłości. Nawiązując do Hyperiona Hölderlina, będzie widział miłość jako element jednoczący wszelką odrębność, ponieważ „to, co daje się dzielić, sprawia miłującym przykrość, jest to rodzaj sprzeczności pomiędzy całkowitym poświęceniem się, jedynie możliwym unicestwieniem, unicestwieniem przeciwstawienia się w zjednoczeniu - a istniejącą jeszcze autonomią; jej tamta stoi na przeszkodzie - miłość jest oburzona na to, co oddzielone,

${ }^{138} \mathrm{CH}$ III/1/2, s. 521.

139 Tamże, s. 523.

${ }^{140}$ G.W.F. Hegel, Pisma wczesne z filozofii religii, tłum. G. Sowiński, Znak, Kraków 1999, s. 387-388. Por. CH III/1/2, s. 523. 
na jego własność; to oburzenie miłości na indywidualność jest wstydem"141.

\subsection{Heglowska Apokalypse i ogień miłości}

Drugą, główną część rozważań Balthasara nad idealizmem niemieckim w Apokalypse kończy analiza filozofii Hegla. Uwzględniając podstawowe zagadnienia odnoszące się do całego jego dzieła związanego z pojęciem apokalipsy, Balthasar koncentruje się na opisie Prometeusza, który iskierkę duszy, zamienioną w światło i jasny płomień, przekształca ostatecznie w trawiący wszystko ogień świata (Weltfeuer). Rozdział poświęcony myśli Heglowskiej rozpoczyna Balthasar strofami z Sonetów do Orfeusza Rilkego:

„Pragnij przemiany. O, zachwyć się śmiało płomieniem, w którym umyka ci rzecz rozbłysła w metamorfozie; ów duch projektujący, kształtujący co ziemskie, lubi w ruchu figury punkt, który zmienia ją w zwrocie"142.

${ }^{141}$ Cyt. za: tamże, s. 524-525.

${ }^{142}$ R.M. Rilke, Sonet II/XII, w: tenże, Elegie duinejskie. Sonety do Orfeusza, tłum. A. Lam, Dom Wydawniczy ELIPSA, Warszawa 2011:

„Pragnij przemiany. O, zachwyć się śmiało płomieniem, w którym umyka ci rzecz rozbłysła w metamorfozie; ów duch projektujący, kształtujący co ziemskie, lubi w ruchu figury punkt, który zmienia ją w zwrocie.

Co się w trwaniu zamyka, to kostnieniu podlega; czy pod strażą szarzyzny pewniejsze być się sądzi?" Uważaj, to co twardsze z dala co twarde ostrzega. Biada -; młot nieobecny się wznosi!

Kto się jak źródło rozlewa, tego poznanie poznaje; wiedzie go w zachwyceniu przez stworzenia pogody, które się często zamyka w początku, zaczyna się w kresie.

Każda przestrzeń szczęśliwa jest dzieckiem lub wnukiem rozłąki. Idą przez nią zdumieni. A przemieniona Dafne pragnie, odkąd jest laurem, byś ty przemieniał się w wietrze. 
Wyjaśniając wybór tego sonetu, Balthasar pisze: „Ta, a nie inna pieśn jest ową beztroską, a jednak upojną pieśnią śpiewaną w tańcu wokół ołtarza, na którym złożona zostaje ostatnia, trawiąca wszystko ofiara Prometeusza, dionizyjskie holocaustum najwyższego czasu"143. Główną myślą filozofii Hegla jest zatem ogień zmieniających się form, który wszystko spala i wyjaśnia bieg historii, wspinając się ku temu, co w górze, ku temu, co nieskończone. W ten sposób realizuje się projekt filozofii eschatologicznej, w której boski ogień zniesiony na ziemię przemienia świat. Heglowski „bosko »trawiący ogień «”, przenika wszystkie rzeczy, a „ogień prawdy oddziela to, co w nich wieczne, od tego, co przemijające" $" 144$.

Nie ulega wątpliwości, że Balthasarowskie odwołania do ognia, który jest jednocześnie ofiarą i sądem, zmierzają do tego, by wszystko, co czasowe, ziemskie, przekazać żywemu ogniowi ducha nieskończonego. Dialektyczna, twórcza negacja ma przemieniać wszystko, co spotyka na swojej drodze. Niemniej jednak Balthasar jest przekonany, że cel Hegla to nie zniszczenie świata doczesnego, lecz jego odnowienie w duchu tego, co nieskończone. Zniszczenie tego, co cząstkowe, oznacza w dużej mierze powrót do początku tego, co istnieje. Heglowską tezę o końcu historii widzi Balthasar w świetle nadchodzącej pożogi świata i sądu nad nim. Jeśli nawet sam Hegel był przekonany, że podstawowe idee oświecenia i rewolucji francuskiej zostały zrealizowane i dzieje świata osiągnęły swój kres, to Balthasar chce widzieć w jego myśli zachowanie tego wszystkiego, co konkretne. Dostrzega nowy ogień, który wprawdzie wszystko przemienia, ale nie niszczy, lecz zachowuje. Jest nim ogień miłości, który pojawi się w rozważaniach Balthasara dopiero po tym, jak przyjrzy się on do-

\footnotetext{
143 AP I, s. 562.

144 Tamże.
} 
kładnie romantycznym doświadczeniom zachwytu i rozczarowania Goethego, Schillera i Jeana Paula oraz estetycznemu oglądowi świata Hölderlina.

Ten „ogień, który roznieca Hegel, jest zatem jednocześnie ofiara i sądem, jednym i drugim jako eschaton. Ze strony człowieka nie ma bowiem żadnej dalszej możliwej postawy ponad transcendencję jako wolę metamorfozy, zachwyt płomieniem, rozlanie się jak światło, chodzenie w zdumieniu. Ze strony Boga, owego kształtującego Ducha, żadnej innej ponad miłość, która dla utrwalającego się w trwaniu staje się młotem i piekłem, a dla ochotnie zmieniającego się - prowadzeniem w zachwycie, poznającym poznaniem"145.

Przemiana dokonująca się dzięki trawiącemu wszystko ogniowi miłości, która wznosi się ku absolutnemu poznaniu, otwiera na nieskończoność, ponieważ „wzajemne przenikanie się obu płomieni - jako gniewnego ognia sądu lub żywego ognia miłości - jest tym, co ostatnie, co ostateczne, z powodu którego wszelkie rozstanie poprzedzało wszystko, jest początkiem, który konczy, szczęśliwym miejscem, najmłodszym dzieckiem rozpoczynającego się końca. Świat Hegla znajduje się dokładnie w owym momencie wzajemnego przenikania"146.

Czym tak naprawdę ma być ów nowy ogień miłości? Nie jest jakimś krótkotrwałym, czasowym przeżyciem, lecz relacją prowadzącą do uznania wzajemnie przenikających się, przeciwnych sobie światów. Relację tę nazwie ostatecznie Hegel duchem, którym rządzi prawo miłości. Wzbogaci ono dotychczasową strukturę mistycznej potencjalności, a Hegel przewyższy w ten sposób Fichtego i Schellinga. Nie ulega wątpliwości, że w nowym rozumieniu mistycznej potencjalności, wyrastającej z metafizyczne-

\footnotetext{
145 Tamże, s. 563.

146 Tamże.
} 
go prawa miłości, Balthasar odnajdzie ponownie ideał związku człowieka z Bogiem. Miłość to „prawda jednostek; jest zatem $\mathrm{w}$ takim samym stopniu konstytuowana przez ich oddanie się, w jakim ona sama owe jednostki konstytuuje jako prawdziwe. W ten sposób na płaszczyźnie egzystencjalnej po raz ostatni powraca mistyczna potencjalność - jako zasada miłości. Ona jest właściwą strukturą świata w każdej z jego rosnących potencji”"147.

Według Balthasara, celem mistycznej potencjalności jest nie tyle zbliżenie się światów natury i ducha do Boga, lecz przede wszystkim związek, jaki tworzy człowiek (indywiduum) z Bogiem. W związku z tym podmiot i otaczający go świat zostają zaakceptowane w ich ziemskiej, światowej postaci, która niesie jeszcze ze sobą niedoskonałość. Dla Balthasara istotny wydaje się fakt, że Hegel włączył konkretny świat natury i człowieka w rozumienie mistycznej potencjalności. Prometejskie zstąpienie na ziemię jako typowy dla natury duch, zmieniający transcendencję w immanencję, zostaje wypełnione przez dionizyjskie przeznaczenie światowości i cielesności. Rozłam pomiędzy transcendowaniem wychodzącym poza, naruszającym immanentne koło, a immanencją jedynie okrążającą, owo koło wytyczającą, został osiągnięty.

Zaakceptowanie przez Balthasara niedostateczności człowieka i natury wymaga jednak pewnego dopełnienia. Duch filozoficzny dąży do przekroczenia myślenia Heglowskiego, które według Balthasara uległo ostatecznie przesadnej racjonalności tego, co irracjonalne. Jego zdaniem, filozofia Hegla zracjonalizowała jedność tego, co absolutne, i tego, co stworzone, Bożej możności stwarzania i jej aktualizacji w świecie. W ten sposób temu, co absolutne, grozi zniszczenie. Dlatego też Balthasar uważa, że w myśli Heglowskiej „waga przechyla się od bieguna prawdziwie mistycznego ku racjonalistycznemu, a wieczność jednostki w du-

147 Tamże, s. 582. 
chu zagrożona jest już upadkiem, który dokona się wkrótce w pozytywizmie lewicy heglowskiej"148. Wprawdzie Balthasar nie rozwija w tym miejscu refleksji nad kontynuacją myśli Heglowskiej w filozofii Marksa, Blocha czy Lukácsa (uczyni to dopiero w ostatnim tomie Apokalypse ${ }^{149}$ ), ale ukazuje kierunek, jaki obrała droga od Kanta do Hegla, prowadząc w historii filozofii do odrzucenia racjonalizmu perspektywy eschatologicznej. Balthasar podkreśla, że perspektywa ta, skrywana niejako przez idealizm, najpełniej ujawniła się dopiero po czasach filozofii Hegla, a przygotowana przez niego racjonalizacja eschatologii zdobyła sobie prawo pozornej naukowości w dziedzinie socjologii dzięki Marksowi, a w biologii dzięki darwinizmowi ${ }^{150}$.

Ostatecznie idealizm heglowski poprzez refleksję przenosi jednostkę w świat konieczności, świat idei. Balthasar uważa, że w filozofii tej widać elementy pewnej przewrotności, a nawet demoniczności, że Hegel próbował ,zrównać bądź wykorzystać myśl chrześcijańską w refleksji filozoficznej" ${ }^{151}$. Ideałem chrześcijanina jest natomiast umiejętność abstrahowania od siebie samego i zobaczenia siebie w Bogu. Idealizm był zatem z jednej strony próbą zastąpienia oświeceniowego racjonalizmu poprzez odnowienie myśli Plotyna i otwarciem bram na to, co starochrześcijańskie, z drugiej zaś ciągle dawał możliwość kontynuacji tegoż racjonalizmu. Wydaje się, że to przede wszystkim w myśli Heglowskiej Balthasar dostrzega siłę racjonalizacji tego, co mistyczne i tajemnicze. Krytyka filozofii Hegla zostaje przez niego przeniesiona na cały idealizm niemiecki. Koncepcja mistycznej potencjalności, wyraźne zakreślenie granicy pomiędzy tym, co racjonalne, i tym, co ponadracjonalne, jest najmniej widoczne właśnie w filozo-

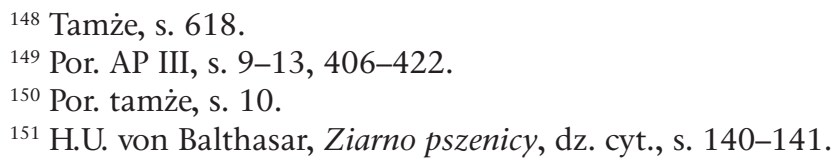




\section{$162 \quad$ Hans Urs von Balthasar wobec idealizmu niemieckiego}

fii Hegla. Zarówno Fichte, jak i Schelling pozostawili tę granicę niejako w zawieszeniu. Nie wystarcza to jednak Balthasarowi. Konstruuje on strukturę, stanowiącą w myśl filozofii Heglowskiej formę zmieniającej się postaci, która musi przejść wielostopniowe przemiany, by osiągnacé dojrzałość, stać się dopełnioną budowlą całościowego spojrzenia na świat. Wprawdzie Fichte podjął próbę przełamania tragicznego dualizmu kantowskiego, ale uczynił to jednostronnie, odwołując się tylko do praktycznego działania podmiotu. Schelling w swych rozważaniach nad jednością przyrody pokonuje jednostronność refleksji Fichtego. Czy jednak mistyczna potencjalność jest jedynym momentem całościowego spojrzenia na idealizm niemiecki?

\subsection{Chytrość rozumu a miłość}

Ukazanie myślenia ludzkiego podmiotu o Bogu, myślenia będącego prawie absolutnym punktem wyjścia wszelkiej prawdy, przypomina chytrą próbę Prometeusza wykradzenia ognia bogom i przyniesienia go ludziom. Chytrość rozumu, a nie chrześcijańską miłość, jak już wcześniej wspomniano, odkryje ostatecznie Balthasar w filozoficznych dziełach Hegla. Wydaje się, że patrzy on na jego filozofię w sposób krytyczny zarówno w Apokalypse, jak i w późniejszej Chwale. Zdawał sobie sprawę, że myślenie Heglowskie próbuje współistnieć z wiarą chrześcijańską. Wiedział też, że Hegel wierzył mocno, iż posiadł wiedzę absolutną, która przypomina wiarę chrześcijańską i ostatecznie wchłania ją w siebie, ale potrzebuje do ostatecznej syntezy rozumienia chrystologii spekulatywnego Wielkiego Piątku ${ }^{152}$. Według Henriciego,

${ }^{152}$ Balthsar odwołuje się w tym miejscu do tekstu Hegla z Filozofii religii. „Kiedy Bóg w Chrystusie przyjmuje skończoność, »skończoność ta w jej najskrajniejszym wyrazie jest złem «, wówczas jest to »nieskończona miłość, że Bóg stał się tożsamy z tym, co dla niego obce, aby je zgładzić. Takie jest 
„Heglowskiej próbie »sporządzenia czegoś takiego jak system prawdy", próbie, która »czy wie on o tym, czy nie, ma w sobie pewien rys bluźnierczy, a już na pewno antychrześcijański«, Balthasar przeciwstawia Chrystusa, »który nazwał siebie drogą i prawdą (...), a przy tym wyniósł On Heglowską tezę, że wszystko, co rozumne, jest rzeczywiste, a wszystko, co rzeczywiste, rozumne, ponad wszystko, co można ująć w pewien system, i potwierdził na zupełnie innej drodze (...)«, a mianowicie przez to, że »zdołał jednym jedynym aktem połączyć to, co absolutnie boskie, z tym, co absolutnie antyboskie, nie w głupstwie i obłędzie tytaniczno-nadludzkiego gestu, lecz w prostocie swego posłuszeństwa «"153.

Według Balthasara, „wielu chrześcijan sądzi (może wraz z samym Heglem?), że w ten sposób dotarli do najgłębszego sensu własnej religii, nie dostrzegając wszakże, iż przeoczyli przy tym wolność Boga w Jego samoobjawieniu, a tym samym niepojętość dobrowolnie dającej siebie miłości (»wiarygodna jest tylko miłość«). Niechcący przeszli ponad nią, mają ją za plecami albo w kieszeni, zamiast widzieć ją stale przed sobą jako godną adoracji tajemnicę"154. Wydaje się, że Balthasar ostrzega przed interpretacją dialektyki heglowskiej i jej wewnętrznej dynamiki miłości w kluczu chrześcijańskim, ponieważ dla Hegla duch dla stania się sobą poprzedza siebie zmysłowością, zakłada w sobie a priori swoje znaczenie. Dlatego też „system ten nie może (...) poradzić sobie ani z problemem Boga (który aby być sobą, potrzebuje świata), ani człowieka (który ma zrezygnować z siebie

znaczenie śmierci Chrystusa «. Ponieważ Bóg jest tym, który umiera, śmierć, to, co negatywne, staje się tym, co pośredniczące, "źródłowa wzniosłość ustanowiona została jako osiąnnięta « oraz zostaje pojęte to, »że to, co ludzkie, skończone, kruche, słabe, negatywne, jest samym boskim momentem, znajduje się w samym Bogu «"; CH III/1/2, s. 526.

153 P. Henrici, O filozofii Hansa Ursa von Balthasara, dz. cyt., s. 164-165.

${ }^{154}$ H.U. von Balthasar, Epilog, tłum. J. Zychowicz, WAM, Kraków 2010, s. $11-12$. 
jako konkretnego indywiduum). Śmierć zostaje tu odarta ze swej godności: staje się spekulatywnym momentem na rzecz stania się bóstwa bóstwem, jako wydarzenie konkretnego życia zostaje zapomniana"155.

Zarówno u Hegla, jak i w całej filozofii idealizmu niemieckiego „nie ma miejsca na miłość. Fichte chyba ją ostatecznie przeczuwał, Hegel znał ją początkowo, ale słońce prawdziwej miłości tylko na krótkie chwile prześwieca mu przez chmury i mgłę. Faust jest beznadziejnym egoistą. Pojęcie ducha jako »bycie w sobie i dla siebie " jest ostatecznie zaprzeczeniem miłości”156. Duch bowiem nie żyje sam dla siebie. Prawdziwa jego realizacja może dokonać się nie inaczej niż w transcendencji, która „nie jest jednak zwyczajnym stanem czy odmianą ducha, lecz prawdziwym »rozdawaniem siebie «, a jeszcze lepiej, »byciem przyjętym « w miłości" ${ }^{157}$.

Najlepszym podsumowaniem będą tutaj słowa samego Balthasara: „Dla idealistów skończoność była zawsze w jakiś sposób tymczasowością, która w samym procesie myślenia i rozwoju świata miałaby zostać wyniesiona w nieskończoność Boga. (...) Hegel chciał uniknąć owej bezpośredniej apoteozy świata, zmieniając pojęcie bytu absolutnego w proces: duch stał się dla niego $\mathrm{w}$ ten sposób dynamiczną zasadą, która przechodzi przez wszystkie poziomy świata skończonego, wciela się, pojmując samą siebie, i wyzwala się tym samym z ograniczoności świata. Skończoność była materiałem do zbudowania wewnętrznej pełni nieskończonego boskiego ducha, ale właśnie przez to jako coś skończonego

155 Tamże, s. 20. Por. na ten temat T. Gadacz, Wolność a odpowiedzialność. Rosenzweiga i Levinasa krytyka heglowskiej wolności ducha, Wydawnictwo Naukowe Papieskiej Akademii Teologicznej, Kraków 1990, s. 101-102.

${ }^{156}$ H.U. von Balthasar, Humanizm chrześcijański, dz. cyt., s. 93.

157 Tamże. 
została ostatecznie unicestwiona i pozbawiona wartości”158. Tak rozumiany idealizm prowadził nieuchronnie do materializmu, dla którego skończona materia była jedyną rzeczywistością, zaś idealne konstrukcje duchowe tworzyły strukturę ideologiczną. Z heglowskiego idealizmu wyrósł historycyzm, dla którego najważniejsze stały się zrozumienie faktycznego przebiegu historii i jakościowa analiza elementu historycznego.

Można zapewne śmiało stwierdzić, że ostatecznym wspólnym celem myślicieli idealizmu niemieckiego jest stworzenie rygorystycznego, wszechogarniającego systemu filozoficznego. Nie ulega wątpliwości, iż droga od Kanta do Hegla mogłaby stanowić pewną formę ciągłości myślenia idealistycznego, gdyby nie pojawiło się na niej wyraźne dążenie do przezwyciężenia dualizmu oglądu rzeczywistości noumenalnej i fenomenalnej. Jeśli skończoność była dla idealistów tymczasowością i miała otworzyć drogę ku temu, co nieskończone, niekoniecznie tylko na drodze procesu myślowego, to Balthasar mógł dostrzegać w idealizmie myśl stanowiącą potencjalnie pewien złoty środek pomiędzy metafizyką starogrecką i chrześcijańską. Przez wyrzeczenie się siebie idealista jest w stanie przygotować miejsce dla tego, co Absolutne. W rzeczywistości jednak chodzi ciągle o podtrzymanie w transcendentalnym podmiocie postawy, w której najważniejszy jest przede wszystkim jego nieustanny rozwój.

Przywołana przez Balthasara mistyczna potencjalność była w istocie pośrednią formą między boską aktualnością a potencjalnością stworzenia i prowadziła do osiągnięcia eschatologicznej integralności, będąc jednocześnie próbą przełamania podmiotu kantowskiego. Jej cel stanowiło nie tyle zbliżenie się światów natury i ducha do Boga, ile przede wszystkim związek, jaki tworzy

${ }^{158}$ H.U. von Balthasar, Filozofia Martina Heideggera z punktu widzenia katolicyzmu, w: PW I, s. 118. 
z Nim człowiek. Nawet jeśli mistyczna potencjalność była gwarantem dialektycznego ruchu w tym, co absolutne, oraz ku temu, co absolutne, i dawała nadzieję na pojednanie człowieka i Boga, to zwycięski marsz Prometeusza przez naturę zmierza ku niej samej. Schelling w zasadniczym nurcie swojej filozofii pozostaje panteistą, zwolennikiem idei jedności wszystkiego. Jego zwrot ku chrześcijaństwu wydaje się Balthasarowi niemożliwy.

Podmiot może stać się prometejskim symbolem przełamania wszystkich przeciwności, pod warunkiem że wspierany jest przez siły nieziemskie. Wtedy skończona wolność człowieka potrafi dać się ponieść ku głębi Absolutu i w ten sposób idealizm wszedłby na religijną drogę refleksji. Balthasar zdaje sobie jednak sprawę, że idealizm nie może wyzwolić się z więzów zamykających człowieka w działaniu, które ten przypisuje przede wszystkim sam sobie. Droga, którą ma przed sobą, wymaga rezygnacji z własnych marzeń o doskonałości i otwarcia się na przyjęcie daru, niepochodzącego od niego samego.

Ten sam podmiot otwarty jest na przenikanie się pierwiastka boskiego i ludzkiego, doświadczanie przeżycia piękna, które przyciąga go do miary piękna absolutnego udzielanego przez sam Absolut. Jednak obecność Absolutu w świecie nie gwarantuje jednostce dotarcia do niego, ponieważ podmiotowi zależy przede wszystkim na entuzjastycznym uwydatnieniu własnych przeżyć. Heglowska perspektywa twórczej miłości przemienia się w działanie przebiegłego rozumu. Owszem, prawda jest całością, ale ostatecznie miłość zostanie wchłonięta przez wiedzę absolutną. 


\section{W sporze $\mathrm{z}$ myśleniem idealistycznym}

Spróbujmy podsumować Balthasarowskie refleksje dotyczące koncepcji idealistycznych. Stworzenie rygorystycznego, wszechogarniającego systemu filozoficznego, który jako cel przyświecał przedstawicielom idealizmu niemieckiego, otwierało drogę do przełamania Kantowskiej filozofii świata dualistycznego. Balthasar od samego początku zastanawiał się, czy systemy pokantowskie rzeczywiście stanowią inną, nawet lepszą formę filozofii, która miała przewyższać Kantowską krytykę rozumu. Zdawał sobie sprawę, że w zderzeniu z chrześcijańską wizją świata myślenie idealistyczne mogłoby zostać ubogacone nowym, pozytywnym impulsem, jeśliby dokonało kroku wstecz, do pierwotnego ideału harmonii, który istniał w świecie starochrześcijańskim. Ideał ten zakładał eschatologiczną jedność człowieka i całej natury. Tym samym chrześcijańska refleksja nad idealistycznym oglądem rzeczywistości mogła pełniej wybrzmieć wzmocniona namysłem filozoficznym. Możliwość kontynuacji myślenia kantowskiego otwierała się przede wszystkim w świadomości fichteańskiej, wzmacniającej transcendentalną metodę najwyższej zasady (ustanawiającego siebie Ja), na której można było budować jednolity system. Jednocześnie jednak Balthasar był świadomy faktu, że kantowski podmiot nie jest zdolny sam z siebie osiągnąć eschatologicznej jedności.

Nie ulega wątpliwości, że z jednej strony Balthasar rozpoznaje $\mathrm{w}$ idealizmie myślenie podobne do własnego. Dotyczy to całego procesu myślowego zbliżania się do tego, co absolutne i nieskończone. Z drugiej zaś strony, ukazuje możliwość innego, często przeciwnego sposobu patrzenia na podstawowe treści myślenia idealistycznego, dostrzegając nawet w tym, co podobne, konieczność zastosowania innej perspektywy rozumienia. Tym, co po- 
dobne, co łączy idealizm i Balthasara, jest poszukiwanie prawdy o rzeczywistości widzianej w perspektywie filozoficznej i teologicznej. Mit Prometeusza pozwala Balthasarowi przedstawić idealizm niemiecki w postaci dialektycznego napięcia między tym, co skończone i nieskończone, jako środek pomiędzy wszystkim i nicością. Człowiek prometejski staje się pośrednikiem między Bogiem i światem. Gdzie zatem zobaczyć Balthasarowskie podobieństwo do niemieckiego idealizmu, a gdzie jego spojrzenie krytyczne?

Zbliżenia się Balthasara do idealizmu trzeba upatrywać w Fichteańskim sposobie rozumienia wolności. Skończona wolność odnajdzie to, co ją wyróżnia spośród innych bytów, w swym koniecznym odniesieniu do Absolutu, gdzie stanie się obrazem i odbiciem podmiotu nieskończonego, który unosi ją ku pełni. Pełnia wolności i zrozumienie siebie pozwalają człowiekowi odnaleźć moc umożliwiającą zwycięstwo nad skończonością. Fichte szuka formy pośredniej między boską aktualnością i potencjalnością stworzenia. Odnajdzie ją w potencjalności mistycznej, która tworzy dialektyczny ruch jedności tego, co absolutnie relatywne, oraz tego, co po prostu absolutne, i powołuje człowieka do wzniosłej misji stawania się w świecie stworzonym żywym obrazem Boga. Misja ta wymaga całkowitej przejrzystości działania podmiotu oraz oddania się temu, co absolutne. Podmiot, o ile pozwoli się pochłonąć przez rozchodzące się w nim życie Boże, będzie mógł doświadczyć wolności absolutnej i prawdziwego piękna udzielanego mu z Absolutu.

Balthasar patrzy przychylnie na myśl Schellinga dotyczącą przedstawienia świata religijnego. Schelling pojawia się bowiem pierwotnie jako prawdziwy eschatolog czasu i wprowadza idealistyczny obraz świata w relacje ze światem boskim. Rozwój historii jako proces odkrywania żyjącego Boga pokazuje, że człowiek 
może interpretować samego siebie w świetle Absolutu i może się nieustannie rozwijać, korzystając niejako z jego siły. Balthasar uważa, że w odróżnieniu do filozofii Fichtego myśl Schellinga pozwala jednostce rezygnować z nieustannego przezwyciężania siebie i dać się ponieść strumieniowi życia boskiego. Bliskość myśleniu idealistycznemu ujawnia Balthasar w próbie zrozumienia piękna, które Schelling przedstawia jako wzajemne przenikanie się pierwiastka boskiego i ludzkiego.

Balthasar przyjmuje Heglowską koncepcję rozumu, o ile jawi się ona jako teza o racjonalności i prawdzie wszelkiego bytu oraz prowadzi do pewnego utożsamienia treści poznania z poszukiwaniem prawdy o rzeczywistości, która ostatecznie ma ukazać swój absolutny, boski charakter. Myśl młodego Hegla, że życie i miłość są w stanie przezwyciężyć wszelkie przeciwieństwo i usunąć wszelkie dualizmy, doceniana przez Balthasara, otwiera możliwość akceptacji Heglowskiej filozofii rozumu, postrzeganej jednak jako teza o racjonalności i prawdzie wszelkiego bytu. Logika heglowska stara się wyjaśniać różnicę między tym, co skończone i nieskończone. Wszystko, co czasowe, ziemskie, ma zostać przemienione przez żywy ogień ducha. Balthasar stara się dostrzec w myśli Hegla odnowienie świata w duchu tego, co nieskończone, z jednoczesnym zachowaniem doczesności i jednostkowości tego, co cząstkowe.

Krytycznemu osądowi poddaje Balthasar fakt, że kantowski podmiot transcendentalny nie jest zdolny sam z siebie osiągnąć eschatologicznej jedności. Uważa, że fichteański podmiot musi poddać się działaniu wolności absolutnej, w przeciwnym razie znajdzie się w obszarze przypadkowych sił rządzących światem. Współpraca podmiotu z wolnością absolutną (boską) nie może leżeć w mocy właściwej samemu podmiotowi. Byłaby wtedy bowiem pozorna. Powinna raczej tworzyć przestrzeń dla samego 
Absolutu, rezygnując jakby z możliwości podmiotowych. Dopóki filozofia wolności będzie wyjaśniana za pomocą kategorii podmiotowych, dopóty pozostanie obca religijnemu aktowi rezygnacji z siebie i nie spełni misji stworzenia miejsca Temu, który chce się uobecnić we wnętrzu podmiotu. Balthasar uważa, że Fichteańska zasada Ja praktycznego, która miała być podstawą do przełamania dualizmu kantowskiego, pozostaje ciągle niezniesiona. Tworzy niejako pośredni stan „unoszenia się” między działaniem a całkowitym oddaniem się Absolutowi. Dlatego też podmiot powinien pozwolić się pochłonąć przez życie Boże, które rozchodzi się w nim samym, podobnie jak to ma miejsce w doświadczeniu estetycznym: podmiot dociera do prawdziwego piękna jedynie wtedy, gdy pozwala się przyrównać do miary piękna absolutnego. Wolność podmiotu ma najgłębszy wgląd we własną wewnętrzność, o ile otworzy się na wolność absolutną, która w podmiocie się sama objawia. Niestety, według Balthasara, filozofia wolności Fichtego zmierza ku temu, by ją wyjaśniać jedynie na podstawie kategorii podmiotu transcendentalnego.

W idealizmie Schellinga, skoncentrowanym na przedstawieniu świata religijnego, Balthasar dostrzega jednostkę, która wprawdzie interpretuje samą siebie w świetle Absolutu, nabiera jednak charakteru mocno subiektywnego. Chociaż człowiek zwolniony z (fichteańskiego) nieustannego przezwyciężania siebie daje się ponieść strumieniowi boskiego życia, stanowiąc w ten sposób część stawania się samego Absolutu, jednakże, według Balthasara, jest on posłuszny przede wszystkim swemu entuzjastycznemu uniesieniu. Jednostka uwydatnia tylko samą siebie, znajduje rozumienie piękna $\mathrm{w}$ sobie i poszukuje estetycznych doświadczeń w świecie. Balthasar uważa, że zarówno Fichte, jak i Schelling pozostawiają człowieka w obszarze jego własnej indywidualności. Indywidualność ta zaczyna niejako konkurować 
z samym Absolutem. Taka droga skazana jest na niepowodzenie. Balthasar jest przekonany, że jedynie odrzucenie przez człowieka zbyt zarozumiałej afirmacji siebie otwiera na zwycięskie i prawdziwe działanie Absolutu. Krytyczna ocena Schellinga dotyczy także momentu, w którym istnieje niebezpieczeństwo, że subiektywne przeżywanie doświadczenia estetycznego pozostawia człowieka samemu sobie. Skupiając się na sobie, traci on możliwość doświadczenia nieskończoności wiecznego piękna. Może ono zostać osiągnięte jedynie w uniesieniu, będącym jednocześnie utratą czasowości. Ta zaś mogła skutkować nastrojem pewnego rodzaju przygnębienia i melancholii. Schelling, jako zwolennik idei jedności wszystkiego, w zasadniczym nurcie swojej filozofii pozostaje panteistą. Jego zwrot ku chrześcijaństwu wydaje się Balthasarowi niemożliwy.

Pomimo pozytywnego patrzenia na rozumienie miłości ludzkiej jako miłości boskiej, przedstawianego w młodzieńczych pismach Hegla, Balthasar uważa, że jego pojęcie miłości, mające wyjaśnić boskie życie w świecie, ostatecznie zniknie we wnętrzu wiedzy absolutnej, a Hegel nigdy nie stał się ani prawdziwym filozofem życia, ani filozofem miłości. Pojęcie ducha jako „bycie w sobie i dla siebie” jest przecież ostatecznie zaprzeczeniem miłości.

Logika heglowska jest w stanie zniwelować granicę pomiędzy tym, co racjonalne, i tym, co ponadracjonalne, utożsamić treści poznania naukowego z poszukiwaniem najwyższej prawdy o rzeczywistości, potrafi wyjaśnić wszelką różnicę, także tę między tym, co skończone i nieskończone, ale wszystko to czyni za cenę zredukowania tego, co nieskończone, do samej logiki. Myślenie Heglowskie, według Balthasara, uległo ostatecznie przesadnej racjonalności tego, co irracjonalne, zracjonalizowało jedność tego, co absolutne, i tego, co stworzone. W ten sposób temu, co ab- 
solutne, grozi zniszczenie, a jednostka zostaje wrzucona w świat konieczności idei. Balthasar uważa, że Hegel chciał zrównać refleksję filozoficzną z myślą chrześcijańską, a przecież ta ostatnia niesie ze sobą umiejętność abstrahowania od siebie samego i zobaczenia siebie przede wszystkim w Bogu. Ostatecznie mistyczna potencjalność dawała nadzieję na pojednanie człowieka i Boga. Wyrastała ona z dialektycznego ruchu w tym, co absolutne, oraz ku temu, co absolutne, wynosząc skończoność i tymczasowość w nieskończoność Boga. W ten sposób natura i człowiek wymagały pewnego dopełnienia. Skończoność była materiałem do zbudowania wewnętrznej pełni nieskończonego boskiego ducha, ale właśnie przez to, jako coś skończonego, została ostatecznie unicestwiona i pozbawiona wartości.

Heglowskiemu systemowi prawdy Balthasar przeciwstawi myślenie chrystologiczne, w którym to, co absolutnie boskie, łączy się z tym, co absolutnie ludzkie, w działaniu wyrastającym z gestu posłuszeństwa Chrystusa. Balthasar chciałby widzieć w myśleniu Heglowskim możliwość powrotu na drogę refleksji religijnej, na której skończona wolność potrafi dać się ponieść ku głębi Absolutu, a człowiek prometejski stałby się symbolem przełamania wszystkich przeciwności. 


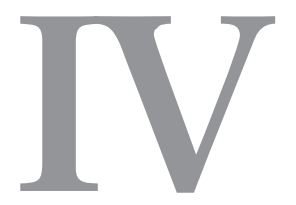

\section{Filozoficzne piękno. Chwała}

Jeśli idealizm pozostaje wykładnią Kanta i pod uwagę brane są nie obiektywne systemy świata, lecz fakt, że w całości musi się on rozwinąć z transcendentalnej struktury aktu myślowego i działającego podmiotu, to akt ten pozostaje pod względem metodycznym zasadą i sednem świata. W sytuacji gdy akt ten jest Absolutem bądź go porządkująco zakłada, pozostaje ważnym punktem odniesienia. Jest to jednak równocześnie powrót do człowieka jako pewnego centrum świata, w takim sensie, że stanowi on odwołanie się do chrześcijaństwa jako momentu przełomowego w procesie odkrywania podmiotowości. Ostatecznie systemy idealistyczne, pomimo wielkiego zbliżenia się do filozofii Plotyna, rozstrzygają wszystko w decyzji rozumienia samego chrześcijaństwa jako czystej filozofii, czyli jako czegoś leżącego w granicach możliwości człowieka, jego dziejów i kultury.

System idealistyczny w swym rozwoju przełamuje myślenie chrześcijańskie, które według Balthasara nieustannie próbuje pod- 
jąć z nim dialog, nawet jeśli w porównaniu z myślą oświeceniową u wszystkich idealistów ujawnia się odczucie wymiaru teologii negatywnej. Jeśli Bóg stanowi wykładnię świata, to nie można Go uprzedmiotowić. Zbliżenie się do myślenia plotyńskiego oddala od założeń kantowskich i wprowadza filozoficzną konieczność związania Boga z Jego objawieniem, a tym samym także z człowiekiem, który sam stanowi Jego wykładnię. Myśleniu idealistycznemu, nawet jeśli wchłonęło w siebie wszelką treść chrześcijańską, brakuje pierwiastka różnicującego, który według Balthasara w Biblii otrzymał miano „chwały”. Ta natomiast „ostaje się i upada wraz z nieprzekraczalnością analogia entis większego niepodobieństwa Boga we wszelkim - choćby największym - podobieństwie"1. Dlatego też idealizm niemiecki, jeśli nawet rozpoczął swój namysł od tożsamości bytu, „zatarasował drogę powrotną ku chrześcijaństwu; nie jest zdolny do zrodzenia chwały, a jedynie estetyki "piękna«. Szeroko rozrastająca się w XIX stuleciu »estetyka jako nauka «stanowi jego owoc”2. Właśnie w rozważaniach na temat „chwały” widać wyraźnie stosunek Balthasara do myśli idealistycznej, dlatego też w tym rozdziale zajmiemy się próbą opisu jego koncepcji estetyki (chwały), ale jedynie w kontekście wybranych wcześniej przedstawicieli myśli niemieckiej.

${ }^{1} \mathrm{CH}$ III/1/2, s. 499. Balthasar przywołuje Baumgartena jako tego, który stwarza „pierwszą »estetykę« jako naukę: obwarowany granicami obszar ludzkiego piękna (kalon) (zmysłowego-mętnego oglądu prawdy), który wszakże postępująco »oświeca się« w obrębie jasnych i wyraźnych prawd, piękna jeszcze całkowicie, jak również u Leibniza, przeżywanego w analogii do antycznego transcendentalnego kalon"; tamże, s. 439.

2 Tamże, s. 499. 


\section{Estetyka chwały}

Z późniejszego okresu twórczości Balthasara pochodzi wspomniana wcześniej teologiczna Trylogia, na którą składają się Estetyka, Teodramatyka i Teologika, i której pisaniem zajmował się ponad ćwierć wieku, prawie do śmierci. Zamierzenie Balthasara było następujące: „Nie przedstawiamy tutaj ani historii filozofii, ani ogólnej historii ducha, pytamy jedynie, co się stało w trakcie stuleci ze starożytnym doświadczeniem chwały Boga; pytamy zaś w taki sposób, aby w ramach filozoficznego szkicu wyłączyć, jak dalece jest to możliwe, specyfikę chwały chrześcijańskiej”3. Pytanie o chwałę było pytaniem o filozoficzne i teologiczne rozumienie piękna. Balthasar zdawał się bronić przede wszystkim myśli oddającej pięknu należne mu miejsce w teologii. Jednocześnie uważał, że stanowi ono także zwieńczenie analiz filozoficznych. Rozważania na temat piękna umieszcza Balthasar w ramach klasycznie rozumianych transcendentaliów: prawdy, dobra i piękna. Właśnie temu ostatniemu przypisuje ważną rolę $\mathrm{w}$ historii myśli filozoficznej i teologicznej. Uważa, że jest ono „ostatnią rzeczywistością, na którą może ważyć się myślący rozum, ponieważ jako niepojęty blask otacza ono podwójną gwiazdę prawdy i dobra oraz ich nierozerwalne odniesienie do siebie. Jest to najbardziej bezinteresowne piękno, bez którego dawny świat nie potrafił pojmować siebie, które jednak niezauważenie pożegnało się ze światem interesów, aby pozostawić je ich żądzy i smutkowi"4. W świecie pozbawionym piękna także dobro traci siłę przyciągania i oczywistość tego, że należy je czynić. Człowiek ulega pokusie, by w świecie, w którym żyje, nie dostrzegać piękna. „W świecie, który nie ufa już sobie na tyle, by potwierdzić piękno,

\footnotetext{
${ }^{3}$ Tamże, s. 7.

${ }^{4}$ CH I, s. 16.
} 
dowody wykazujące prawdę utraciły swą logikę. Oznacza to, że sylogizmy wprawdzie działają poprawnie, jak maszyny rotacyjne lub kalkulatory, które bezbłędnie dają ściśle określoną liczbę wyników na minutę, ale samo wnioskowanie jest mechanizmem, który nikogo nie zniewala, a sam wniosek nie zamyka sprawy"'. Niewyjaśniona pozostaje tajemnica bytu. Niezrozumiała jest też ciągle ludzka egzystencja z wolnością, będącą istotą ludzkiego ducha, ponieważ dla człowieka, który „nie potrafi już odczytywać piękna, świadectwo bytu staje się niewiarygodne"6.

Balthasar chce bez wątpienia wskazać na obecność piękna i jego ważność dla rozumienia świata. Ważniejsze wydaje się jednak wprowadzenie kategorii piękna po to, by uwrażliwić na objawy tego, co boskie, w świecie i ludzkich dziejach. Balthasar jest przekonany, że to, co boskie, nie może być dostrzegalne i oddziaływać mocą, jeśli nie otworzymy się na przyjęcie i zrozumienie piękna odwiecznego, które ukazuje się pod widocznymi formami.

Pomysł Balthasara, by przedstawić to, co w chrześcijaństwie wyjątkowe i niedościgłe, w formie syntetyzującego obrazu, doprowadził go do stworzenia planu trylogii, której pierwsza część poświęcona została teologicznej estetyce. Zatytułował ją Herrlichkeit. Eine theologische Ästhetik (Chwała. Estetyka teologiczna), ponieważ, jak sam tłumaczy, Bóg jest rozpoznawany przede wszystkim „po swojej boskości (Herr-heit), wspaniałości (Hehr-heit), po tym, co Izrael nazywa »kabod «, a Nowy Testament "gloria «" . Bóg przychodzi na świat „po to, aby Siebie, chwałę swojej wiecznej trójjedynej miłości ukazać i promieniować nią, w owej »bezinteresowności «, która jest wspólna prawdziwej miłości i prawdziwemu pięknu"s. Sam Balthasar przedstawiał swoje dzieło

\footnotetext{
5 Tamże, s. 17.

${ }^{6}$ Tamże.

${ }^{7}$ H.U. von Balthasar, Retrospektywa, w: OMD, s. 58.

${ }^{8}$ Tamże.
} 
w następujący sposób: „»Chwała « odpowiada na płaszczyźnie teologicznej temu, czym na płaszczyźnie filozoficznej jest transcendentalne "piękno «; piękno stanowi jednak w myśli Zachodu od Homera i Platona, przez Augustyna i Tomasza do Goethego, Hölderlina, Schellinga i Heideggera ostateczną, podsumowującą właściwość obejmującego wszystko bycia jako takiego, jego ostateczną, tajemniczą moc promieniowania, to, dla czego kocha się je jako całość, pomimo okropności, jakie kryje ono dla bytów"9.

Myślą przewodnią dzieła miała być zatem próba ukazania piękna jako podstawowej kategorii filozoficznej zastosowanej w myśleniu teologicznym. Kategoria ta wspomagana pojęciem „postaci” zaczerpniętym z twórczości Goethego miała uwrażliwić na więź, która istnieje pomiędzy pięknem a religią.

W historycznym ujęciu kształtowania się pojęcia piękna podkreślano, że jest ono bez wątpienia ,zjawiskiem”- epiphaneia. Tak postrzegali je Grecy, Platon, stoicy, Plotyn. Średniowieczne teologie estetyczne rozumiały piękno w świecie jako „przejawianie się nieprzejawiającej się Jedni, objawiającej swoją transcendencję w jednoczącym porządku wielości" ${ }^{10}$. Filozofia idealistów niemieckich będzie stanowiła kontynuację myśli średniowiecznej w tym sensie, że „w przejawianiu się nieprzejawiający się (Bóg) Duch coraz wyraźniej zbiega się z duchem ludzkim, tak że oś tej epifanii przebiega przez sam środek człowieka: on jako duch przejawia się jako ciało, on jako to, co ogólne (idea), przejawia jako to, co szczegółowe, on jako Bóg jawi się jako człowiek"11. Jednak

9 Tamże. Później jednak Balthasar doda: „Chodzi głównie nie o »piękno « w światowym czy też filozoficznym (transcendentalnym) znaczeniu, lecz o jego wywyższenie w »chwale« jako rozbłyśnięciu boskości samego Boga, odzwierciedlającej się w życiu, śmierci i zmartwychwstaniu Jezusa oraz według Pawła w chrześcijanach spoglądających na swego Pana”; tenże, Jeszcze jedno dziesięciolecie, w: OMD, s. 69.

${ }^{10} \mathrm{CH}$ III/1/2, s. 545.

11 Tamże. 
według Balthasara wraz z myślą niemiecką „estetyka ścisła cofnie się od stanowiska Hegla do Kanta i Schillera, to znaczy do subiektywnego i psychologicznego idealizmu, którego wymiary wyznaczają z jednej strony przewidywalna jeszcze przez człowieka »idea«, zaś z drugiej umożliwione przez jego strukturę zmysłową »wcielenie « tych idei"12.

Balthasar był przekonany, że nieskończoność i niewyrażalność boskiego elementu może być jakoś „dostrzegalna” w widocznych formach świata: „Porwać i zachwycić może tylko to, co zawiera postać. Błyskawica wiekuistego piękna dociera do nas tylko poprzez postać. Istnieje taki moment, gdy wybuchające światło, występujący Duch, opromienia wewnętrzną postać - a od sposobu i od miary, w jakiej to czyni, zależy, czy jest to piękno »zmysłowe « czy »duchowe«, urok czy godność - zaś bez postaci człowiek nie może być porwany i wpaść w zachwyt. Zachwyt jest początkiem chrześcijaństwa"13.

Piękno i widzialna postać były wprawdzie drogą do zrozumienia objawienia, ale jednocześnie dawały Balthasarowi możliwość ujęcia podstawowych tez idealizmu niemieckiego, mocno zakorzenionego w myśleniu religijnym. Jak już wspomniano, Balthasar był przekonany, że w wielu przypadkach idealizm niemiecki ożywiała myśl religijna, szczególnie zaś estetyczne rozumienie elementu religijnego. Doświadczenie estetyczne stanowi punkt wyjścia ku doświadczeniu religijnemu, gdy otwiera się na transcendentne piękno, które swe źródło ma nie w subiektywności podmiotu, ale w bycie Absolutnym ${ }^{14}$.

12 Tamże.

${ }^{13}$ CH I, s. 28.

14 Warto w tym miejscu zwrócić uwagę, że Balthasar, odwołując się do protestanckiej teologii Karla Bartha, polemizuje ze stanowiskiem Kierkegaarda, który postulował wyraźne rozróżnienie rzeczywistości estetycznej i religijnej. Według Kierkegaarda, piękno rozumiane w sposób dialektyczny 
Klimat właściwy romantyzmowi sprzyjał myśleniu, które sytuowało doświadczenie estetyczno-religijne na płaszczyźnie przeczucia tego, co nieskończone, przeczucia, które wynikało z aspiracji elementu duchowego myślącego podmiotu. Owszem, aspiracje myślącego i przeżywającego świat podmiotu musiały zostać wprowadzone w świadomość więzi, która ujmowała zależność pomiędzy podmiotem skończonym i nieskończonym. Więź ta z kolei otwierała drogę do doświadczenia elementu absolutnego (boskiego) w głębi samego podmiotu, ale głębi oczyszczonej ze zbytniej „wewnętrzności”, która nie zamykała na oddanie się samemu Bogu. Wprawdzie doświadczenie estetyczne miało prowadzić do doświadczenia religijnego, istniało jednak niebezpieczeństwo, że otwarcie się na to, co nieskończone, dryfuje w kierunku estetyki antropologicznej, w której piękno nie spotyka się z aspiracją transcendowania siebie, lecz jedynie $\mathrm{z}$ własną podobizną. Balthasara interesuje ciagle to, co nieuwarunkowane, co stanowi ostateczne przeznaczenie myślącego i wierzącego człowieka. Zmysł religijny znajduje w boskim pięknie wezwanie do szukania prawdy o sobie

sprawia, że jednostka zamyka się w sobie i pozostaje w obrębie samej siebie, nie wychodząc poza ramy celowej samej w sobie natury. Zarówno Barth, jak i Balthasar postrzegają piękno jako źródło i blask istoty Boskiej. W swej Dogmatyce Barth pisze: „Boskość i wolność Boga zasadza się i opiera na tym, że Bóg w sobie samym i we wszystkich swoich dziełach jest jednym, wiecznym i właśnie dlatego zawsze obecnym, wszechmocnym i chwalebnym"; K. Barth, Die kirchliche Dogmatik, t. II/1, Evangelischer Verlag, Zürich 1940, s. 495. Chwała jest pełnią boskości. Istotę Boga można uchwycić w Jego objawieniu się. W ten sposób też boska chwała jest Bogiem dającym się w sposób widoczny w swoim objawieniu. Ta możliwość „uchwycenia” Bożej chwały prowadzi do próby związania pojęcia chwały z pojęciem piękna. Por. na ten temat także: AP I, s. 695-735; M. Urban, Rozpacz tożsama z estetyką?, w: Człowiek wobec rozpaczy w filozofii Sørena Kierkegaarda, red. M. Urban, W. Zuziak, Wydawnictwo Naukowe PAT, Kraków 2004, s. 196-210; E. Rocca, Die Wahrnehmung des Glaubens. Kierkeggards Dimis-Predigt und die „Philosopischen Brocken”, „Kierkegaard Studies” 2004, ed. N.J. Cappelørn, H. Deuser, J. Stewart, Berlin-New York 2004, s. 18-38. 
samym według innej miary, która nie jest miarą podmiotu, ale tego, co inne, co jednak zamieszkuje w nim samym. Otwarcie się na to, co nieskończone, wymaga porzucenia samego siebie, by odnaleźć prawdziwe źródło swojego przeznaczenia.

$\mathrm{W}$ podmiocie jest obecny ten, który jest większy ode mnie i który, ponieważ jest Absolutem, nie może być określony jedynie jako „inny”. Odkrycie to stanowi dla Balthasara moment przezwyciężenia kantowskiej myśli reprezentowanej przez Fichtego, że duch skończony poddaje się Duchowi nieskończonemu po to, by zostać ostatecznie duchem w nim samym. Ta tajemnica bliska jest właściwie całemu idealizmowi niemieckiemu od Fichtego i Schellinga, przez Goethego, Schleiermachera, Novalisa, Hölderlina, po Hegla. Otwarcie się skończonego ducha na siebie samego, by „usłyszeć” nieskończonego Ducha, to wyzwanie dla całego idealizmu niemieckiego.

Świat „chwały” i filozoficznego piękna Balthasar porównuje do ogrodu namalowanego przez Richarda Seewalda, z którym wspólnie tworzył i wydał dzieło Das christliche Jahr ${ }^{15}$ : „Z Zachodem, namalowanym przez niego w halach monachijskiego ogrodu dworskiego (Hofgarten), istotowo spokrewnione jest to, co pełni rolę obrazu w Herrlichkeit III/1. Obaj dobrze wiemy, że nie ma tu zatrzymywania się na dłużej i że namiot ziemskiego mieszkania zostanie zwinięty wraz z otaczającymi go umiłowanymi krajobrazami ducha"16. Wydaje się, że istotą estetyki miało być „odsłonięcie (apokalipsa) prawdy Boga i człowieka jako Boga-Człowieka i Człowieka-Boga - jednej i drugiej otwartej na siebie $\mathrm{w}$ apokaliptycznej głębi i dopiero $\mathrm{w}$ tym śmiertelnym

${ }^{15}$ H.U. von Balthasar, Das christliche Jahr [in Bildern von Richard Seewald und Worten von Hans Urs von Balthasar], Josef Stocker, Luzern 1944.

16 Tenże, Retrospektywa, dz. cyt., s. 56-57. 
stanięciu twarzą w twarz niepojęte i niewyobrażalne usprawiedliwienie dobra"17.

Rozważania o charakterze metafizycznym wskazywały przede wszystkim na szeroką perspektywę podejścia do rozumienia bytu, obejmującą zarówno mit, filozofię, jak i religię. Ponieważ mit i religia naturalna wydawały się trudne do pogodzenia z myślą chrześcijańską, nicią przewodnią refleksji Balthasara pozostaje historia filozofii i filozoficzna próba podejścia do rozważań estetycznych poświęconych teologii chwały i filozoficznemu pojęciu piękna. Po tym wielkim przedtakcie, w którym można widzieć jakby nowe, obszerniejsze opracowanie Apokalypse, kolejne przemyślenia filozoficzne prezentują się skromniej, mimo że mają do przekazania rzeczy ważne i nowe. To, co chrześcijańskie, musi zostać możliwie jak najgłębiej zanurzone w myśl filozoficzną, z zachowaniem jednak rozróżnienia tego, co chrześcijańskie, i tego, co takie nie jest. Rozróżnienie to uwidaczniało się na wiele sposobów. Balthasar uważał, że „chwała elementu boskiego w świecie była (u Homera) pierwszym uformowanym doświadczeniem Zachodu"18. Sztuka czerpiąca z doświadczenia mitu niosła ze sobą dynamiczność tworzenia, ustępując z czasem miejsca filozofii. Filozofia zaś u przedsokratyków i Platona „nasączona światłem mitu”19 doprowadziła do dwuznacznego rozumienia transcendencji. Czy będzie ona samowładzą człowieka, czy też Objawieniem samego Boga? Starożytność pozostawiła w ten sposób niejednoznaczność rozumienia transcendencji, a Balthasar zastanawia się, czy chrześcijaństwo ze starożytnego pojęcia piękna stworzy mieszkanie dla boskiej chwały. Wreszcie po wielu zagmatwanych ideach historycznych od Boecjusza, przez św. Tomasza, do Kuzańczyka pojawi się nominalizm, który ograbi „stworzenie z wszelkiego Bożego

${ }^{17} \mathrm{CH} \mathrm{II/1/2,} \mathrm{s.} 343$.

${ }^{18}$ H.U. von Balthasar, Retrospektywa, dz. cyt., s. 60-61.

19 Tamże. 
światła"20. Brak boskiego światła jest wyzwaniem, by znaleźć nowe drogi, które pozwolą ponownie odszukać element boski w świecie. Balthasar dostrzega trzy takie drogi.

Pierwsza z nich to „chrześcijańska teologia harmonii”, której początek stanowią Eckhart i mistycy średniowieczni, jednak, według Balthasara, nie ma na niej miejsca na świat. Drugą drogę tworzy „ponowne zanurzenie się uskrzydlonej wcześniej teologii na dnie antyku (od Kuzańczyka poprzez renesans, barok, oświecenie do Goethego i Heideggera)"21. Na tej drodze brakuje jednak wyraźnego określenia tego, co chrześcijańskie. Wreszcie trzecią drogę stanowi „filozofia ducha (ponownie od Eckharta i Kuzańczyka do Kartezjusza, Leibniza, Spinozy i idealistów niemieckich)"22. Balthasar dostrzega na niej niebezpieczeństwa, które dotyczą całej myśli idealistów niemieckich i które będą obecne w wielu jego rozważaniach nad idealizmem. Balthasar uważa bowiem, że jeżeli „duch (ludzki) pojęciem przytłacza wszelkie bycie, wówczas gaśnie chwała bycia, zostaje ona zastąpiona »wzniosłością " myśliciela (Kant, Schiller), która u Hegla znowu należy do przeszłości: wówczas pozostaje tylko straszna fatalność materialistyczna"23.

Droga ducha prowadzi Balthasara do przekonania, że nowożytność nie znajduje właściwych możliwości powiązania metafizyki i teologii, bowiem zapomnienie o bycie skutkuje zapomnieniem o tym, co absolutne, o Bogu. Niemniej jednak myśliciel chrześcijański nie ma innego wyjścia, jak tylko wziąć na siebie ciężar metafizycznej odpowiedzialności ${ }^{24}$.

\footnotetext{
20 Tamże.

21 Tamże.

22 Tamże.

23 Tamże.

${ }^{24}$ Por. tamże.
} 


\section{Historia doświadczenia chwały}

Myśl Balthasara dotycząca chwały przeszła swego rodzaju ewolucję. Obejmowała ona spojrzenie zarówno teologiczne, jak i filozoficzne, by ostatecznie zakorzenić się w tym, co specyficznie chrześcijańskie, w chwale samego Boga. Balthasar opisywał ją w następujący sposób: „W mojej estetyce przeszedłem daleką drogę; poczynając od kategorii »świeckiej estetyki« (w pierwszym tomie), które mogą pomóc zrozumieć coś teologicznego, przechodziłem jednak coraz bardziej do tego, co specyficznie, biblijnie chrześcijańskie, mianowicie do kabod, chwały Bożej, która nie jest jakąś estetyką, lecz samym Bogiem w akcie Jego objawiania się. Chodziło mi o teorię postrzegania (aisthesis) tego, co chrześcijańskie w świecie. To, co się postrzega, to prawda, chwała ubogiej miłości Boga"25.

Najważniejsza dla naszych rozważań wydaje się część Trylogii poświęcona miejscu estetyki w europejskiej historii filozofii i historii ducha. Rozważania na temat idealizmu niemieckiego umieszcza Balthasar w końcowej części dzieła. Chodzi przede wszystkim o tom III,1 Chwaty, zatytułowany Metafizyka ducha. Filozofii niemieckiej poświęca ponad 130 stron tekstu. Interesujący nas okres nowożytności poprzedza Balthasar syntetycznym ujęciem historii filozoficznej idei ducha i doświadczenia chwały Boga w ciagu wieków. Wydaje się, że punktem centralnym, a jednocześnie punktem odniesienia historycznego pozostaje dla Balthasara średniowiecze. Jego zdaniem, to ono przejęło starożytne doświadczenie świata, który objawia Boga i w którym kosmiczne kategorie piękna służyły jako aparat pojęciowy dla wyrażenia Jego powszechnego objawienia. Myśl scholastyczna wywodząca się ze środowiska

${ }^{25}$ Duch i ogień. Rozmowa Michaela Albusa z Hansem Ursem von Balthasarem, w: OMD, s. 88 . 
franciszkańskiego i dionizyjskiego ,przyniosła raz jeszcze (...) powszechne transcendentalne spojrzenie na byt, w ramach którego nie tylko wierzący, ale i filozofujący chrześcijanie zdobywali się na twierdzenie, iż we wszelkim istnieniu dostrzegamy wprost odblask wiecznego dobra i piękna"26. Balthasar uważa, że takie rozumienie bytu nie znalazło kontynuatorów w historii. Interpretacja Arystotelesa dokonana przez awerroizm przynosiła jednak inne spojrzenie na ontologię i próbowała widzieć zrozumienie ostatecznych podstaw bytu w ludzkim rozumie, wykluczając przy tym wszelką wiedzę objawioną. Takie spojrzenie, uważa Balthasar, doprowadziło do ponownego przemyślenia granic pomiędzy filozofią a chrześcijaństwem. Można się w tym miejscu zastanawiać, czy pozbawione struktury filozoficznej chrześcijaństwo mogło wystarczająco opisać i uzasadnić własną nieredukowalną do niczego treść. Balthasara interesuje jednak inny bieg myśli historycznej. Otóż dostrzega on myśl wywodzącą się z filozofii Platona, którą określa jako mityczną możliwość objawiania się Boga, a która znalazła swoją kontynuację w rozważaniach Balthasara nad idealizmem niemieckim. Jest on przekonany, że transcendentalna nauka o pięknie osiągnęła równowagę w teorii bytu św. Tomasza; równowagę, w której istnienie stanowi pełnię rzeczywistości wyłaniającej się z Boga i która w skończonym świecie uzyskuje swoje oparcie i spełnienie. Równowagę tę jednak trudno było w historii utrzymać, dlatego też pojawiły się różne drogi myślenia. Balthasar wymienia dwie: „na jednej istnienie ulega formalizacji jako najbardziej uniwersalne pojęcie rozumu, co ma miejsce u Jana Dunsa Szkota, a tym samym rozum przyznaje sobie (...) ogląd i rozporządzanie bytem" ${ }^{27}$. W ten sposób istnienie staje się najwyższą, ale jednocześnie pustą kategorią. Owszem, można próbować za

\footnotetext{
${ }^{26} \mathrm{CH}$ III/1/2, s. 7.

27 Tamże, s. 10.
} 
pomocą rozumu dokonać syntezy kategorii istnienia z konkretnymi formami lub, jak to ma miejsce w idealizmie od Kanta do Hegla, synteza ta jest już, niejako wcześniej, samodzielnie skonstruowana, ale wtedy, uważa Balthasar, formalizowanie nie może zawierać kategorii piękna, a tym samym: ,jak długo skotystyczny formalizm stanowić będzie model naukowego myślenia w nowożytności, należy oczekiwać, iż coraz bardziej będzie jej obca świadomość jakiejkolwiek transcendentalnej chwały"28.

Druga droga, stworzona przez Mistrza Eckharta, prowadzi do ponownego zrównania istnienia z Bogiem. Balthasar wydaje się jednak zainteresowany bardziej Plotynem, który takiego zrównania uniknął, „ustanawiając źródłem wszystkiego dobro, które jest ponad bytem" 29 . Balthasara intryguje fakt, że trudno sobie wyobrazić, czy według modelu Eckharta poza bytem Boga mogłaby istnieć rzeczywistość świata, gdyż „prędzej czy później mistyczne samounicestwienie się stworzenia musi przeobrazić się w ponowne objęcie w posiadanie boskiego bytu, który od Dunsa Szkota jawi się zdecydowanie jako duch i wolność" 30 .

Ostatecznie średniowieczna mistyka poda $\mathrm{w}$ wątpliwość istnienie Chwały Bytu absolutnego, dlatego też Balthasar konkluduje, że zarówno formalizacja jako uniwersalne pojęcie rozumu, jak też mistyczne zjednoczenie istnienia jawią się jako dwie przenikające się formy panteizmu ducha lub rozumu. Ich dialektyczne wzajemne przenikanie się jest pomostem między średniowieczem a nowożytnością. Niemniej jednak transcendentalne roszczenia rozumu do uniwersalności z jednej strony i chrześcijańska myśl oparta na Objawieniu z drugiej nie są w stanie neutralnie ze sobą istnieć. Dlatego też Balthasar jest przekonany, że „od tego po-

\footnotetext{
28 Tamże.

29 Tamże.

30 Tamże, s. 11.
} 
dwójnego dziedzictwa, platońskiego i chrześcijańskiego, myślenie ludzkie nie uwolni się już nigdy"31.

Idealizm i myśl oświeceniowa to, co chrześcijańskie, zwiążą z filozofią transcendentalną. Według Balthasara, jednym ze źródeł takiego myślenia jest teologia i filozofia protestancka reprezentowana przez Bartha, a wywodząca się z idealistycznej filozofii Schleiermachera. Wydarzenie duchowe, które sięgnie od Kanta do Hegla, znajdzie oparcie w reformacji. W konfrontacji z transcendentalnymi aspiracjami rozumu i idealizmu Balthasar chce odzyskać na nowo pierwotne tory myślenia estetycznego i źródłowy sens chwały ${ }^{32}$.

\section{Metafizyka ducha}

W poszukiwaniu pomostu między średniowieczem a nowożytnością skieruje się Balthasar ponownie ku starożytności. Późne średniowiecze nie wskazuje bowiem bezpośredniej drogi ku myśleniu nowożytnemu. Powrót do starożytności daje Balthasarowi możliwość ponownego otwarcia się na treści, które niosło ze sobą chrześcijaństwo. Próba ukrycia treści chrześcijańskich pod inną postacią w celu ich ocalenia nie mogła się powieść. Analizując zadania chrześcijanina $\mathrm{w}$ rozumieniu tego, czym tak naprawdę są treści chrześcijańskie, Balthasar wskazywał, że rozumienie to musi być podjęte „z najwyższego poziomu”. Był przekonany, że chrześcijanin , jeśli nie wzniesie się na ten poziom, będzie nerwowo i niespokojnie wahać się pomiędzy zredukowaną do filozofii

31 Tamże, s. 12.

32 Por. tamże; por. także H.U. von Balthasar, Karl Barth. Darstellung und Deutung seiner Theologie, Hegner, Köln-Olten 1951, s. 181-259, oraz Christlicher Universalismus, w: Verbum Caro (Skizzen zur Theologie I), Johannes Verlag, Einsiedeln 1960, s. 260-275. 
współczesnego świata, pociągniętą i zafascynowaną przez jej urok modernistycznością (Modernität), która pod pozorem dotrzymywania kroku czasom oddaje się i zatraca w każdym rozkwitającym właśnie prądzie i kierunku, a dumną samowystarczalnością, która opierając się na mającej kiedyś znaczenie średniowiecznej syntezie chrześcijaństwa i świata, zdaje się omijać każdy wewnętrzny spór z filozofią nowożytną" 33 .

Jeśli zatem niemożliwa okazała się próba ukrycia treści chrześcijańskich w jakiejś formie przedchrześcijańskiej, należało znaleźć inne rozwiązania. Balthasar odwołuje się ponownie do Eckharta, który wskazał droge „osobowej relacji między duchem skończonym i nieskończonym, przy czym ducha (posiadającego siebie w wolności) rozumie się jako istotę, sens i cel wszystkich istnień pozbawionych ducha bądź znajdujących się poniżej ducha" 34 . Powstała w ten sposób metafizyka ducha, która nie odwołuje się do metafizyki natury, ale szkicuje analogię między „stwórczą spontanicznością Boga oraz naśladowczą mocą twórczą człowieka: obydwie są rozwinięciem istoty każdorazowej jedności ducha" 35 . Przejście od natury do ducha zakreśliło nowy obszar: duchowy i osobowy związek Boga i człowieka. Przejście to jednak w rozwoju świadomości chrześcijanina nie było jedynie krokiem w przód. Balthasar, pozostając wierny pozytywnemu znaczeniu świata stworzonego, uznaje przejście od natury do ducha za pewnego rodzaju krok wstecz. Pozostawiając niejako na marginesie teofaniczne znaczenie kosmosu, człowiek spotyka Boga wyłącznie w swoim wnętrzu. Ponieważ kosmos traci swoje pierwotne znaczenie, pozostaje jedynie „materiałem”, który człowiek może dowolnie wykorzystywać do swoich potrzeb. Bez pośrednictwa kosmosu filozofia ducha staje się z jednej strony owocem chrze-

\footnotetext{
${ }^{33}$ OZFK, s. 13.

${ }^{34} \mathrm{CH}$ III/1/2, s. 411.

35 Tamże.
} 
ścijaństwa, z drugiej zagrożeniem, ponieważ widzenie świata jako materiału ciąży ku materializmowi ${ }^{36}$.

Myślenie nowożytne, pozbawione pośredniczącego rozumienia bytu, zostaje natomiast wtrącone w pewnego rodzaju monizm ducha. Balthasar porządkuje je, wskazując postulaty aprioryczne, które próbują przywrócić utraconą całość kosmosu. Pierwszym z nich była filozofia Kartezjusza, która przesuwając środek metafizyki ku podmiotowi myślącemu, uzyskuje dostęp do istnienia nie tylko skończonego, ale także nieskończonego ducha. Balthasar uważa, że Kartezjańskie „ograniczenie filozofii do płaszczyzny ducha wiedzie do nieuniknionej tożsamości: »myślę, więc jestem « to nie żadna konkluzja, lecz bezpośrednia intuicja, jeżeli nie psychologiczna, to z pewnością spekulatywna"37. Stwierdzenie „myślę, więc jestem” pod względem formalnym jest wyjątkowe i ma charakter absolutny. Tożsamość istnienia i ducha, człowieka i bytu absolutnego, mająca początek w mistyce Eckharta, poprzez Kartezjusza prowadzi Balthasara do ponownego przyjrzenia się owej „iskierce duszy”38, o której pisał już w Apokalypse. Spojrzenie to dotyczyło przede wszystkim rozumienia „chwały” w filozofii niemieckiej na drodze od Kanta do Hegla. Dlatego też myśl ta zostanie poddana dalszemu rozwojowi w filozofii Kanta, w jego „źródłowej syntezie jedności apercepcji, $\mathrm{w} » \mathrm{Ja}$ « Fichtego, w Schellinga punkcie zróżnicowania, w procesie Ducha Hegla" ${ }^{39}$. Już tutaj Balthasar ma wątpliwości, czy w obrę-

${ }^{36}$ Por. tamże, s. 412.

37 Tamże, s. 413.

${ }^{38}$ Tamże. „Przez to jednak, że idealizm ekscentryczne centrum utrwala jako ów punkt systemowy w podwójnym $\delta \iota \alpha$, pojawia się ostatnia konsekwencja: Bóg, jako iskierka duszy, rozbudzona, rozniecona, aby być całością, jako rzeczywiście centryczne centrum (którym człowiek nigdy być nie może), jest Absolutny tylko w całości tego, co relatywne, jest Wiecznym przez czas, Niezależnym przez to, co zależne"; AP, s. 143.

${ }^{39} \mathrm{CH}$ III/1/2, s. 413. 
bie ducha można jeszcze mówić o pojęciu chwały, która przecież związana jest z doświadczeniem świata objawiającego Boga.

Możliwości skończonego podmiotu wydają się mieć charakter nieskończony. Niosą ze sobą zdolność współtworzenia świata. Jego rozwój przyjmuje dwojaką postać: „,w swoim »rzeczywistym « aspekcie rozumiany jest jako ewolucja natury w kierunku ducha, zaś w swoim ogarniającym aspekcie »idealnym « jako to, co już naprzód przez (formalnie) absolutnego ducha zaprojektowane, dzięki czemu duch zyskuje swoją treściową (egzystencjalną) całość". Filozofia ducha jawi się tym samym jako w pełni ukształtowana rzeczywistość, w której przyroda (natura) bez wstępnego projektu ducha absolutnego staje się niezrozumiała. Człowiek złożony z ducha i ciała jest jednocześnie tym, który projektuje swoje własne stawanie się w świecie, i tym, który ten świat posiada dla swojego stawania się. Balthasara nurtuje jednak ciągle następujący problem: jeśli świat został filozoficznie ukonstytuowany na boskich zasadach, to zadaniem chrześcijanina jest odkrywanie i odsłanianie owych fundamentów i ukazywanie ich światu.

\section{Wzniosłość i piękno}

U początku idealistycznego myślenia na temat piękna stoi filozofia Kanta. Refleksje nad nią Balthasar rozpoczyna dwiema ogólnymi uwagami. Pierwsza to wskazanie na fakt, że myśl Kanta stanowi punkt wyjścia do stworzenia obrazu świata, którego estetycznym dopełnieniem jest wizja eschatologiczna ujmowana od strony ducha, wizja, którą pozostawi w spadku niemieckiej filozofii Schillera, Fichtego oraz Schellinga i Hegla. Druga uwaga to próba konkluzji płynąca z przemyśleń na temat całości filo-

${ }^{1}$ Tamże. 
zofii Kanta. Otóż wskutek dokonanego przez niego krytycznego ustanowienia granic rozumu ,»idealizm krytyczny « nie dopuszcza żadnej przestrzeni, w której możliwe byłoby doświadczenie świata jako przejawiającej się chwały Boga"2. Skoro teoretyczna władza rozumu jest ograniczona, Kant przedstawia nieograniczoną przestrzeń dla postępów rozumu praktycznego. Balthasar uważa, że w przestrzeni tej „chwała” zostaje zastąpiona moralną i ostatecznie estetyczną wzniosłością. Gwiaździste niebo z Krytyki praktycznego rozumu jest przykładem czegoś wzniosłego, będącego równocześnie czymś pięknym³ ${ }^{3}$. Balthasar mniemał, że Kant dostrzega jednak, iż światy natury i ducha mają swój początek w jedynym rozumie, który jest podstawą i źródłem wszelkich istot, a który ma charakter boski. Dlatego też Kanta nie interesuje zasadniczo rzeczywistość świata zewnętrznego, zależącego od doniosłości i możliwości świata duchowego, od obiektywności i realności pojęcia. Mimo obiektywności poznania pojęciowego pozostaje niepoznawalna rzecz sama w sobie. Balthasar uważa, że stan niepoznawalności „w mniejszym stopniu sprowadzić należy do myślowo nieusuwalnej reszty w bycie niż do subiektywnego doświadczenia receptywności, która zatrzymała się tymczasem jako nieredukowalny pierwotny fenomen poznania, do czasu, gdy absolutni idealiści zastosują również konieczną redukcję do tego fenomenu"4.

Rozum kantowski, by zrealizować w pełni swoją naturę, musi dostrzec skończoność swego poznania teoretycznego, wychodząc

2 Tamże, s. 439.

3 „Dwie rzeczy napełniają umysł coraz to nowym i wzmagającym się podziwem, im częściej i trwalej nad nimi się zastanawiamy: niebo gwiaździste nade mną i prawo moralne we mnie"; cyt. za: CH III/1/2, s. 440. Balthasar uważa, że to słynne zdanie winno być rozpatrywane w kontekście podziwu Kanta dla nieba, wyrażonego w dedykowanym królowi pruskiemu dziele Ogólna historia naturalna i teoria nieba.

${ }^{4} \mathrm{CH}$ III/1/2, s. 445. 
poza nie. Jednakże jako „rozum czysty” nie ma żadnego doświadczenia w odniesieniu do tego, co ponadzmysłowe, nie ma zatem możliwości uprzedmiotowienia swego poznania, musi się zadowolić jedynie ideami. Tak rozumiana struktura rozumu musi prowadzić do przejścia od postawy teoretycznej do praktycznej, gdzie to, co nie jest możliwe do uchwycenia w sposób pojęciowo-zmysłowy, będzie mógł zdobyć w działaniu. Według Balthasara, Kant zdaje sobie sprawę, że „metafizyka, która została zakazana rozumowi teoretycznemu, praktycznie jest nie tylko dozwolona, lecz narzucana przez niego samego, ponieważ sama nie może się zrozumieć inaczej, jak tylko przyjmując założenia transcendentne (a nie »transcendentalne «!)" ${ }^{5}$. Rozum praktyczny postuluje wprawdzie swoje transcendentne założenia wynikające $\mathrm{z}$ absolutnej powinności, nie może jednak teoretycznie ich dowieść. Balthasar dostrzega w tym miejscu twórczą rolę wewnętrznego działania podmiotu, które pozwala niejako przekroczyć próg tajemniczej aktywności Boga w podmiocie. Zdolność rozumu praktycznego, pomimo jego skończonego charakteru, do skierowania się ku temu, co nieskończone, stanowi jego „wewnętrzną wzniosłość” i staje się tym, „co objawia mu Bóg, nie zaś własna wzniosła chwała Boga, której nie może on nawet dojrzeć w czystym rozumie"6.

Taki sposób myślenia, uważa Balthasar, odsyła Kanta do antycznej i chrześcijańskiej formy teologii negatywnej, gdzie pomimo prób poznawczych ze strony podmiotu Bóg pozostaje „najgłębiej Nieznanym” i „w całej nieskrytości najgłębiej Ukrytym"7. Odwołanie się Kanta do teologii negatywnej stanowi dla Balthasara pewnego rodzaju oczyszczenie i wyzwolenie w interesującej go metafizyce ducha. Władza poznawcza praktycznego

\footnotetext{
${ }^{5}$ Tamże, s. 448.

6 Tamże, s. 449.

7 Tamże.
} 
rozumu, nawet jeśli otwiera drogę do Absolutu, nie może zapewnić poznania obiektywnego. Człowiek nie może zatem obiektywnie rozpoznać Boga jako „całkiem innego”, nawet Jego istnienie $\mathrm{w}$ jakiś sposób założone $\mathrm{w}$ prawie moralnym nie prowadzi do żadnego uobecnienia ludzkiej władzy poznawczej. W myśl teologii negatywnej, rozum nie może wytłumaczyć bezwarunkowości prawa praktycznego, gdyż „i tak nie pojmujemy wprawdzie praktycznej bezwarunkowej konieczności moralnego imperatywu, ale pojmujemy przecież jego niepojętość (a w niej znak Boga), a to jest wszystko, czego można słusznie wymagać od filozofii, która w zasadach dociera aż do granic rozumu ludzkiego"s. Postulaty rozumu praktycznego winny przejawiać się na fundamencie doświadczenia transcendentalnego, jako „czyste warunki możliwości aktu estetycznego, o ile ten powinien być rozumiany w swojej totalności" pirycznych staje się „czystym formalizmem”.

Według Balthasara, istota etycznej wolności jest samouchwyceniem osoby duchowej ${ }^{10}$, nie można jej przedstawić za pomocą jakiegokolwiek obrazu, ale sama może być także źródłem religii. Kant domaga się czynienia dobra ze względu na dobro samo. $\mathrm{W}$ ten sposób dobro ukazuje się człowiekowi jako imperatyw, a powinność nie jest jeszcze identyczna z chceniem. Według Kanta, „dla boskiej, i w ogóle dla świętej woli, imperatywy nie posiadają ważności; powinność jest tutaj nie na miejscu, ponieważ

${ }^{8}$ Cyt. za: CH III/1/2, s. 450.

9 Tamże, s. 451.

${ }^{10}$ Por. tamże. Tutaj czysty rozum może oprzeć się na sądzie syntetycznym a priori, który do tej pory stosował intelekt w odniesieniu do doświadczenia zmysłowego. Sąd ten zaistnieje, „o ile w wolnym ujęciu siebie zniesiona zostaje różnica między powinnością i wolą (...), następnie, ponieważ w absolutności imperatywu etycznego wyłania się a priori istnienia Boga"; tamże, s. 452. 
wola już sama z siebie jest z konieczności zgodna z prawem"11. Człowiek odczuwa w sobie z jednej strony powinność, z drugiej dobro, wobec którego owa powinność istnieje.

Balthasar zdaje sobie sprawę, że „dla Kanta nie może istnieć przy wszelkiej świadomości tajemnicy - nic, co byłoby »nadprzyrodzonością « w tym sensie, że zasadniczo mogłoby się znajdować poza ludzkim duchem w jego otwarciu jako rozum praktyczny. Zatem ostatecznie przestrzeń pomiędzy Bogiem i człowiekiem może być wymierzona przez człowieka (w jego wolności, która styka się z Absolutem i zawiera go w sobie"12. Takim myśleniem Kant rozpoczyna rozumienie filozofii religii $\mathrm{w}$ duchu idealizmu niemieckiego, który ukierunkuje myślenie religijne w taki sposób, iż „wszelka teologia postawiona zostanie z góry przed trybunałem filozofii"13. Balthasar zastanawia się, czy Kant nie zmierzał tu do sytuacji, w której twórcza aktywność podmiotu transcendentalnego czyni z siebie i swego dynamizmu wartości absolutne. Odpowiedzi na to pytanie trzeba będzie poszukać w rozważaniach estetycznych.

Pierwiastek moralny filozofii Kanta odsłania się, według Balthasara, w tajemnicy Boga-Człowieka. Początku zaś Kantowskiej estetyki szuka on w rozumieniu znaczenia dwóch pojęć: wzniosłości i piękna. Zaznacza przy tym, że to „wzniosłość” staje się zrozumiała na podstawie swojego związku z ,pięknem” i w kontraście z nim. Jeśli poznanie teoretyczne polega na relacji spostrzeżenia i pojęcia do przedmiotu, to $\mathrm{w}$ poznaniu estetycznym spostrzeżenie i pojęcie odnoszą się do podmiotu. W Wykładach $z$ metafizyki Kant formułuje krótką zasadę poznania estetycznego: „Stosownie do tego mamy dwie doskonałości: logiczną i estetyczną. Pierwsza doskonałość pojawia się wtedy, kiedy moje poznanie

\footnotetext{
${ }^{11}$ Cyt. za: CH III/1/2, s. 452.

12 Tamże, s. 457-458.

13 Tamże, s. 458.
} 
zgadza się z przedmiotem; zaś druga doskonałość, kiedy moje poznanie zgadza się z podmiotem"14.

Sąd estetyczny w zasadzie nie przejawia żadnego „zainteresowania" obiektywnym istnieniem przedmiotu. Kiedy jednak zmysłowość pozbawiona interesowności „podoba się” podmiotowi, wówczas pojawia się kontemplacyjne trwanie przy pięknie, które nieustannie się wzmacnia i tworzy. Wtedy „doświadczenie piękna odgranicza się już od czystej »przyjemności «, która wzbudza interesowną skłonność ku temu, co przynosi radość, od »prawdy«, którą przenika zainteresowanie istnieniem przedmiotu, od »dobra «, które zawiera zainteresowanie istnieniem przedmiotu bądź działaniem"15.

Sąd estetyczny wnosi roszczenie do powszechnej, subiektywnej ważności. W odróżnieniu od sądu o tym, co zmysłowo przyjemne, nie pozostaje czysto subiektywny, lecz dotyczy „czegoś $\mathrm{w}$ transcendentalnej strukturze podmiotu, mianowicie pobudza »wolną grę« władz poznawczych - zmysłowej wyobraźni i duchowego pojęcia, podrażnia je niejako w ich wewnętrznej obiektywnej »harmonii «, wprawia w drganie, piękno w przyjemność, brzydotę w niechęć" ${ }^{16}$. Udzielanie się odczucia piękna jest dla Kanta koniecznym warunkiem możliwości powszechnego udzielania się naszego poznania.

Trudność, jaką w estetyce Kantowskiej dostrzega Balthasar, polega na tym, czy można wyizolować fenomen piękna z pozostałych transcendentaliów: prawdy i dobra. Otóż przy połączniu piękna z prawdą i dobrem Kant mówi jedynie o pięknie zależnym, które nie wykazuje swego charakteru różnicującego. Ten wyłania się jedynie wtedy, gdy nie zakłada się zgodności sądu smaku z rozumem, to znaczy piękna z dobrem. „Czyste piękno jest tutaj

\footnotetext{
${ }^{14}$ Cyt. za: CH III/1/2, s. 459.

15 Tamże, s. 459.

${ }^{16}$ Tamże.
} 
w podwójnym sensie formalne: kiedy - co w odniesieniu do tradycji antyczno-chrześcijańskiej jest niedopuszczalne - abstrahuje od związku prawdy z dobrem, aby pojęcie poddać »oczyszczającej « destylacji, oraz kiedy odpowiednio »abstrahuje « od wszelkiej przedmiotowości oraz wszelkiego zainteresowania etycznego (...), aby rozkoszować się formą jako niezwiązaną, znaczącą w sobie, poprzez czyste zainteresowanie czystą formalną harmonią władz poznawczych" ${ }^{17}$. W Kantowskiej estetyce zatem transcendentalia odnoszą się do transcendentalnego rozumu, co powoduje, że jeden aspekt pojawia się tylko pod warunkiem abstrahowania od wszystkich innych. Dzieje się tak dlatego, że czysty rozum kantowski jest rozumem, któremu brakuje zakorzeniania w bycie nieskończonym ${ }^{18}$. Jeśli istotą piękna jest „czyste powiązanie władz podmiotu, posiada dokładnie ten sam charakter zawieszenia skończoności w sobie samej, który tam, gdzie zanika zniewalająca moc imperatywu etycznego, (...) może prowadzić do czystej, nie tylko wolnej od wszelkiego zainteresowania i celu (sztuka dla sztuki), lecz ostatecznie pozbawionej sensu gry skończonego istnienia z sobą samym w nicości" ${ }^{19}$. W ten sposób piękno jako wolność od określonego pojęcia staje się ważne jedynie jako czysta idea, a wtedy także „najwyższy wzór, pierwowzór smaku jest tylko ideą”, wszelkie piękno jest tylko „przykładem jakiegoś powszechnie ważnego, ale niedającego się sformułować prawidła”20. Odwołując się do Plotyna, Balthasar zgadza się z faktem, że owszem, symetria, prawidłowość, harmonia mogą być warunkami piękna, lecz nigdy jego istotą.

\footnotetext{
17 Tamże, s. 461.

18 Por. tamże.

19 Tamże.

${ }^{20}$ Cyt. za: tamże, s. 462; por. także E. Kant, Krytyka władzy sqddzenia,
} $\S 17$ oraz $\S 18$. 
Piękno zatem, w którym nie uwydatnia się jego formalnie różnicujący charakter, a które Kant, według Balthasara, nazywa „pięknem zależnym”, niosącym ze sobą wolność od wszelkiej celowości, ma „szczególne powinowactwo z człowiekiem, który pod względem moralnym jest jedynym w przyrodzie celem samym w sobie" ${ }^{21}$. Skoro w stosunku do człowieka można ukształtować pewien rodzaj ideału, mianowicie ideę rozumową, która fundament ma w moralności, to naoczne przedstawienie idei moralnej stawia przed człowiekiem artystą nowe wyzwanie, w którym „piękno musi się wznieść ponad siebie, przyjmując formę wzniosłości"22.

Balthasar uważa, że Kantowskie rozważania nad ideą wzniosłości prowadzą do pewnego rodzaju „głębokiej czci dla tego, co wzniosłe" 23 , i to nie tylko w odniesieniu do człowieka, ale także do Boga, z „którego świętością w swoim wiecznym dążeniu wola nigdy nie może się zejść" 24 . W namyśle Kanta nad wzniosłością dostrzega Balthasar sprzeciw przeciwko Schillerowskiej koncepcji wzniosłości rozumianej przede wszystkim jako wyniesienie człowieka ku niemu samemu. Kant domaga się aby „rozumowe, samo w sobie celowe (moralne) dobro musiało - jeśli wydamy o nim sąd estetyczny - być przedstawione nie tylko jako piękne, ile raczej jako wzniosłe (...); natura ludzka bowiem zgadza się z owym dobrem nie sama przez się, lecz tylko na skutek gwałtu, jaki rozum zadaje zmysłowości" 25 . Dlatego też - uważa Balthasar - „Kant zatrzymał się przed progiem niemieckiego idealizmu oraz jego estetyki tożsamości, wzbraniając się przed tym, aby »gwałt « z konieczności zadany człowiekowi przekształcić jeszcze raz

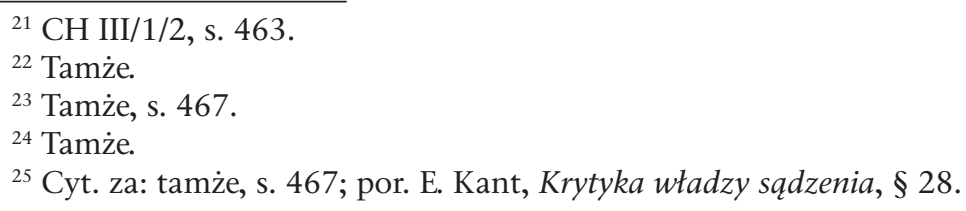


w wyższe piękno. Zachowuje chrześcijańską wrażliwość, która jakkolwiek ukryta, zdaje sobie sprawę z krzyża"26. Wprawdzie człowiek kantowski pozostaje otwarty na to, co wzniosłe, świadomy jest jednak faktu, że mimo nieustannego dążenia do tego, co nieskończone, jego wola nigdy nie może się złączyć ze świętością Boga.

\section{Chwała i dzieło sztuki}

Chrześcijański punkt wyjścia dostrzega Balthasar początkowo w filozofii Fichtego w ustanowieniu zasady Ja doskonałego, wolnego posiadania siebie w czynie. Dopiero bowiem Bóg objawienia stał się Ja, człowiek Jego ty, a objawienie Boga jest jednocześnie objawieniem bytu. Innymi słowy, skończoność staje się objawieniem nieskończoności. W ten sposób Bóg i świat tworzą całość. Balthasar, odwołując się do języka estetyki, widzi tę całość jako „dzieło sztuki, w którym Bóg jest »światłem «, świat »formą «, Bóg jest życiem, świat kształtem. Kategorie artystycznej (świeckiej) estetyki (...) wypożyczają swój język ze szczególnym uprzywilejowaniem metafizyki. Świat jest »wyrazem « Boga" ${ }^{27}$.

Treścią zachodniej metafizyki było - według Balthasara przekonanie, że Bóg jest istotą niepoznawalną, niemożliwą do ujęcia w pojęciu, pozostaje tajemnicą także w swoim stworzeniu i objawieniu. Sądził on, że Fichte wpisuje się w tę myśl alternatywnej filozofii, która przebiegała „pomiędzy spinozjańskim fatalizmem i kantowską nauką o wolności”28, i uznawał jego wybór za błędny. Sądził bowiem, że właściwa droga alternatywnej filozofii winna przebiegać myślami Augustyna i Pseudo-Dionizego,

\footnotetext{
${ }^{26} \mathrm{CH}$ III/1/2, s. 467.

27 Tamże, s. 498.

${ }^{28}$ Tamże, s. 503.
} 
którzy „umieścili głębiej sięgającą ideę Boga Biblii rozjaśniająco w idei antycznej: Bóg we wszystkim i ponad wszystkim"29. Droga ta prowadziła do filozofii neoplatońskiej, gdzie „ostatecznie zakwestionowany zostaje każdy rodzaj zależności Boga od jego przejawiania się zarówno w królestwie duchów, jak i w świecie, zaś wspaniałe światło tajemnicy niewyrażalnej Jedni staje się chwałą niedostępnej światłości, która uniża się, powodowana czystą miłością"30. Ta miłość jest relacją ludzkiej wolności jako wyrazu niewyrażalnej tajemnicy bytu. Nie ulega wątpliwości, że Balthasar zmierza w takim myśleniu ostatecznie ku chrystologii rozumianej jako formy filozoficznej nauki o stworzeniu. Fichte zdaje się powoli otwierać na przestrzeń, w której relacja między Bogiem i człowiekiem zostaje wchłonięta w wewnątrzboski proces tworzenia. Fichteańska jaźń, która postrzega siebie jako „»wolność“ wyłaniająca się z bytu i występująca wobec bytu jako »istnienie«, sama może być odczuwana jako czysta łaska i dlatego może okazać się prawdziwie wdzięczna, wyłącznie oddając wolność z powrotem bytowi" 31 . Wydaje się, że Fichte bliski jest stwierdzenia, że Boga nie można traktować jako przedmiotu i widzieć Go jako czystą negację wszelkiej pojęciowości. Droga, którą przeszedł Fichte, niesie z sobą konieczną dialektykę: „Najpierw Bóg został wchłonięty przez czyste ja (faza pierwsza do ok. 1800 roku), następnie ja (»istnienie «) poddane zostało w Bogu procesowi pustoszenia, aż do poświęcenia osobowej nieśmiertelności”32.

${ }^{29}$ Tamże.

30 Tamże.

31 Tamże, s. 504.

32 Tamże. Balthasar przywołuje tutaj fragment sonetu Fichtego Nichts ist denn Gott, und Gott ist nichts denn Leben (cyt. za: CH III/1/2, s. 505):

„Jawnie zasłona unosi się z ciebie, Jest nią twoje ja; obumiera to, co zniszczalne, A odtąd tylko Bóg w twoim dążeniu żyje.

Dojrzyj to, co to dążenie przetrwało, 
Balthasar jest przekonany, że panteistyczny charakter myślenia Fichteańskiego otwiera na dialektykę nieskończoności i skończoności. Z niej wyłania się chrześcijański obraz miłości i modlitwy. „To, co pojmuję, staje się przez samo pojmowanie skończone i nie da się nigdy zamienić w nieskończoność, przez nieskończone nawet stopniowanie. Różnisz się od skończoności nie stopniem, lecz rodzajem. (...) Ale twe względy i stosunek do mnie, skończonego i do wszelkiej nieskończoności są dla mnie jasne: niech będę, czym powinienem" ${ }^{33}$. Dialektyka ta zatem z jednej strony jawi się jako wolność i czyn i jest koniecznym kształtem Boga, z drugiej zaś wiedzą o tym, czego wiedzieć nie można. Jeśli zostaje ona zniesiona w samym Bogu, to przeobraża się „w myślenie wyciszonego, wręcz nieświadomego działania wypływającego z ekstatycznego spojrzenia posłanego w źródło swojego powołania" ${ }^{34}$. To działanie mające swe źródło w ekstatycznym spojrzeniu jest dla Balthasara rdzeniem etyczności i tego, co estetyczne, nabiera ponownie rysu plotyńskiego. Przywołuje w tym miejscu Balthasar słowa Fichtego: „Niech Państwo pomyślą sobie na przykład świętą kobietę, która wyniesiona ku chmurom, prowadzona przez zastępy niebieskie, które zatapiają w niej swoje zachwycone spojrzenia, otoczona całym blaskiem niebios, których najwyższą ozdobą i rozkoszą jest ona sama, która - jedyna spośród wszystkich - nie jest w stanie dostrzec tego, co wokół niej się dzieje, całkowicie zatopiona i pogrążona w jednym uczuciu: jestem Pańską służebnicą, niech mi się stanie to, czego on pragnie; niech Państwo teraz nadadzą temu jednemu uczuciu w tym otoczeniu kształty ludzkiego ciała, otrzymacie Państwo bez wątpienia pięk-

Wnet zasłona jako zasłona staje się widoczna dla ciebie, A dostrzegasz teraz odsłonięte boskie życie".

${ }^{33}$ J.G. Fichte, Powołanie człowieka, tłum. i wstęp A. Zieleńczyk, Hachette, Warszawa 2010, s. 169; por. CH III/1/2, s. 505.

${ }^{34} \mathrm{CH}$ III/1/2, s. 505. 
ność w pewnej określonej formie. Czym jest to, co sprawia, że postać ta jest piękna? Czy poszczególne członki i części? Czy nie jest to raczej wyłącznie jedno uczucie, które przelewa się przez członki i części?"35.

Balthasar określa myśl Fichtego jako głęboko patetyczną, polegającą już nie tylko na posiadaniu idei piękna, ale na „byciu pochwyconym przez idee" ${ }^{36}$, która rodzi pobożność w sensie antycznym i chrześcijańskim i która przenika idealistyczną formę myślenia. Właśnie przez rozwijającą się logikę tej formy zostanie jednak ogarnięty fichteański entuzjazm estetyczny. Balthasar widzi w niej strukturę, która prowadzi Fichtego do negatywnych konkluzji. Jeśli bowiem „ja jest absolutnym czynem i absolutną wiedzą, zaś jako »fundament " posiada byt nie do przezwyciężenia, czy Bóg sam, na ile można go ująć jako ducha, nie posiadałby takiego mrocznego fundamentu, z którego się wyłania? Czy owa mroczna baza wszystkich istot i postaci zmysłowych nie byłaby raczej nicością, pozbawioną świadomości Nirwaną, a dla wyłaniających się rzeczy wprawdzie pięknem, ale jedynie tragicznym, które musi znieść samo siebie?" ${ }^{37}$. Wtedy istotą piękna jest sprzeczność oraz nieustanne przezwyciężanie się przez siebie. Ostatecznie, według Balthasara, Fichte odrzuca opowiedzenie się za „żywym Bogiem” Biblii ${ }^{38}$.

Za najbardziej estetyczną uważa Balthasar - jak to już zostało wspomniane w rozdziale trzecim - filozofię Schellinga, która jawi się jako równowaga między nieskończonością i skończonością. Jest ona jednak nie filozofią chwały, lecz filozofią sztuki, ponieważ filozofią chwały nie może być żadna filozofia tożsamości ${ }^{39}$.

\footnotetext{
${ }^{35}$ Cyt. za: tamże, s. 506.

${ }^{36}$ Cyt. za: tamże.

37 Tamże, s. 506-507.

38 Por. tamże, s. 499.

${ }^{39}$ Por. tamże, s. 514-515.
} 
Otóż zgodnie z myślą Schellinga wszelka nieskończoność przejawia się w „kształcie”, który widoczny jest i zrozumiały w tym, co nieskończone, a co istnieje w formie piękna. W filozofii tożsamości Schellinga znika kantowski problem relacji między pięknem i wzniosłością, bowiem „nie może istnieć żadne prawdziwe, obiektywne przeciwieństwo między pięknem i wzniosłością: Prawdziwe i absolutne piękno jest zawsze wzniosłe, wzniosłość (jeżeli jest prawdziwa) jest zawsze piękna"40.

Schelling jest świadomy przenikania się transcendentaliów, są one ostatecznie różnymi sposobami widzenia Absolutu. Estetyka rozumiana jako przejawianie się nieskończoności w skończonej postaci jest mitologią. Balthasar uważa, że jest ona jednym z zasadniczych problemów młodego Schellinga. „Ponieważ wieczne stawanie się Boga przejawia się czasowo w świadomości świata, religia musi pojawić się najpierw w skończonej formie (naturalnej) mitycznego piękna, z której Schelling słusznie wyprowadza przedchrześcijańską sztukę, zanim przeobrazi się ona w nieskończoną formę (duchową), objawienia-piękna, gdzie Bóg naprawdę staje się człowiekiem, z całą powagą cierpi i umiera w skończoności, aby zmartwychwstając, powrócić do wiecznego świata idei i tam wpisać obraz rzeczywistego człowieka"41. W ten sposób Chrystus jest zamknięciem mitologii, wraz z Nim zmienił się kierunek myślenia i rzeczywistości: nieskończoność prawdziwa przeszła w skończoność. Ta zmiana jednak nie ma na celu ubóstwienia skończoności, skończoność ma być ofiarowana Bogu i z Nim pojednana na nowo.

Schellingowskie rozumienie mitu przeniknięte jest, według Balthasara, od samego początku głębokim racjonalizmem. „Tam, gdzie nieskończoność utrzymuje swoją przewagę nad skończono-

\footnotetext{
${ }^{40}$ Cyt. za: tamże, s. 515.

${ }^{41}$ Tamże, s. 516.
} 
ścią (objawienie), skończoność (która była najpierw mitycznie ważnym naczyniem nieskończoności) może służyć jedynie jej estetycznej kontemplacji" ${ }^{42}$. Element mityczny rozpływa się w filozofii sztuki. Filozoficzna relacja między Bogiem i człowiekiem, między nieskończonością i skończonością, jest jednocześnie relacją zawartą w objawieniu Chrystusa (jako objawionego Boga-Człowieka) i może być uchwycona w spojrzeniu estetycznym. Synteza wszelkich sprzeczności znajduje się ostatecznie w ,»idei cierpiącego dobrowolnie Boga «, w przeciwieństwie do bogów mitologii, bowiem »ci nie cierpią, lecz są szczęśliwi w swojej skończoności «"43.

Jaka jest zatem relacja teologii i filozofii? Czyżby pierwsza miała być wchłonięta przez drugą? Balthasar uważa, że w rzeczywistości takie wchłonięcie jest tylko pozorne. Z perspektywy estetycznej: „łaskawość i wolność objawienia Bożego stworzonemu człowiekowi były już zawsze wliczone w konieczny proces stawania się Boga Bogiem i człowieka człowiekiem, co oznacza równocześnie stawania się Boga człowiekiem i człowieka Bogiem. Wszelkie mówienie o »dobrowolności« nie może tutaj znaczyć więcej niż »fundamentalny charakter « piękna, które uzyskało systematyczne pierwszeństwo $\mathrm{w}$ interpretacji prawdy i dobra bytu" 44 .

Filozofia niesie dla Schellinga jednoznaczność rozumu w pojęciu. Rozum zdaje sobie sprawę, że „Boga może skonstruować tylko jako ideę, nie zaś jako żywotną rzeczywistość (...), myślące ja nie chce jego idei, lecz »Boga samego «"45. Myśl drąży samą siebie, uznaje swoje granice i ustanawia poza samą sobą byt, który może ją w pełni ukształtować. Schelling zdaje sobie sprawę, że

\footnotetext{
${ }^{42}$ Tamże, s. 517.

${ }^{43}$ Cyt. za: tamże, s. 518.

${ }^{44}$ Tamże.

${ }^{45}$ Tamże, s. 519.
} 
rzeczywiste istnienie poza wszelką ideą „wyrywa rozum »absolutnie ekstatycznie « z siebie samego, (...) rozum musi się po prostu »poddać«, obumrzeć samemu sobie, dać pierwszeństwo bytowi”46. Balthasar przywołuje tutaj słowa Schellinga: „Stosownie do swej czystej natury rozum ustanawia tylko nieskończony byt; na odwrót zatem jest on w ustanawianiu tego samego jak nieruchomy, jak odrętwiały, quasi attonita, lecz odrętwiały wobec pokonującego go bytu, aby przez to poddanie siebie dotrzeć do prawdziwej i wiecznej treści, której nie może znaleźć w świecie zmysłowym, do poznania której doszedł rzeczywiście, a którą dlatego właśnie posiada na wieczność" ${ }^{47}$. Według Balthasara, Schelling ostatecznie rozumie jednak to ekstatyczne działanie (pozostawienie wszystkiego oraz wyjście naprzeciw) jako przedsięwzięcie rozumu. Rozum powinien zachować się jedynie jako możność w stosunku do bytu, dla którego wszelkie myślenie nie może znaleźć podstawy bądź początku. Jeśli rozum pozostaje wierny swej naturze, „może jego nieskończonej możności poznania odpowiadać jedynie nieskończony akt" ${ }^{48}$. Wszelkie działania wobec wychodzącego naprzeciw żywego Boga mogą być przedmiotem teologii, a nie filozofii objawienia. Balthasar podsumuje filozofię Schellinga słowami: „Schelling budował na »niedającym się dokończyć moście«, pojmując objawienie jako najwyższą formę mitu; lecz tam, gdzie należało umieścić wspornik, pozostał niepewny, miara odstępu wypadła mu z ręki"49.

Wspornik taki odważnie postawi dopiero Hegel, u którego „nigdzie bardziej nie można poszukiwać chwały niż w totalności absolutnego ducha" ${ }^{50}$. Przeprowadzi on chrześcijańską wiarę w wie-

\footnotetext{
46 Tamże.

${ }^{47}$ Cyt. za: tamże, s. 520.

${ }^{48}$ Cyt. za: tamże, s. 520.

49 Tamże, s. 521.

50 Tamże, s. 519-520.
} 
dzę filozoficzną. Jego myślenie przebiega opozycyjnie w stosunku do Fichtego i Schellinga: „Podczas gdy tamci krążyli wokół zasady tożsamości, (...) Hegel we wczesnym okresie swojej twórczości długo zmagał się z Chrystusem, sensem jego życia oraz tym, co po sobie pozostawił, aby następnie wyraźnie zdecydować, co można $\mathrm{z}$ tego materiału zużytkować filozoficznie oraz wcielić w jego system, co zaś jako niestrawną resztę odrzucić" ${ }^{51}$. Życie Boskie miało być wyjaśnione za pomocą miłości, ostatecznie jednak całość myślenia zniknie we wnętrzu wiedzy absolutnej. Analizując filozofię Hegla, Balthasar pisał: „Do strony zjawiskowej Boga należą »wiara « (bądź »przedstawienie«: religia) i »ogląd « (sztuka), obydwie spoglądają poprzez skończoność na przejawiającą się w niej w sposób ukryty nieskończoność; filozofia jako wiedza ogarnia i przewyższa obie, nie niszcząc ich, podczas gdy jednak tamte wznoszą swoje spojrzenie ku chwale, filozofia bądź wiedza Boga jest samą chwałą" 52 .

W polemice ze Starym Testamentem Hegel dostrzeże element, który jest zbyteczny w jego systemie myślowym. Tym elementem będzie wyniosłość Boga nad światem, starotestamentowa forma chwały Bożej, kabod ${ }^{53}$. Wyniosłość Boga nad światem jest dla Hegla zasadą, która rozrywa Boga i świat, „nieszczęśliwą świadomością" z Fenomenologii ducha, a pojęcie Boga staje się abstrakcyjne i pozbawione treści. Hegel jednoznacznie rozstrzygnie, że „to, co zostało »objawione « historycznie, jest tym samym »objawione " raz na zawsze" ${ }^{54}$. Zatem nie ma już nic tajemnego w Bogu, a religia jest „wiedzą ducha o sobie samym jako duchu”" W5 ten sposób otwiera Hegel przejście wiary w wiedzę i filozofię. Wiara

\footnotetext{
51 Tamże, s. 521.

52 Tamże, s. 523.

53 Por. tamże, s. 527.

54 Tamże, s. 531.

55 Tamże.
} 
jest wiedzą w specyficznej formie, która „rozpoczyna się wraz ze zmysłowym przedstawieniem, (...) lecz substancjalnie zawiera już w sobie wiedzę duchową. Pod tym względem odróżnia się od mitu, w którym boskość postrzegana i osiągana jest w formie skończonej" "56. Jeśli Bóg objawił się w całości w człowieku, wówczas i myślenie całości bytu jest chwałą, a przecież - zauważa Balthasar - „wcześniej chwałą było to, że »Bóg równocześnie jest ponad swoim odsłonięciem się, jednocześnie w nim, odróżniając się od niego «"57. Tymczasem „owo w-p on a d zostaje bez reszty sprowadzone do [samego] w" ${ }^{58}$.

Myśl Heglowska wyrasta z wnętrza całości, która wchłania w siebie wszelkie rozdarcia i przeciwności w świecie natury i ducha. Tę całość widzi Hegel zarówno w sensie metafizycznym, logicznym, jak też historycznym i estetycznym. Moment estetyczny ukazuje ,spełniony ogląd siebie przez nieskończonego i absolutnego Ducha w tym, co skończone, doczesne, ludzkie (...), jest nieomal wyłącznie zobrazowaną świadomością promiennej szczęśliwości samej wiedzy absolutnej" ${ }^{59}$. Według Balthasara, to właśnie estetyka jest jednym z najbardziej dojrzałych dzieł Hegla. Skoro dotyczy ona przede wszystkim spełnionego oglądu siebie przez absolutnego Ducha, to piękno natury zajmuje najmniejsze, tymczasowe miejsce. Ponieważ duchowy blask Absolutu wypływa ze skończoności, estetyka staje się dla Hegla „nauką o pięknie sztuki" ${ }^{60}$. Czym jest sztuka? Według Balthasara, jest ona dla Hegla przedstawieniem idei, „»konkretnego absolutnego pojęcia siebie samej« w całości jej skończonej naturalnej wykładni ro-

\footnotetext{
56 Tamże.

${ }^{57}$ Cyt. za: tamże, s. 532.

58 Tamże.

59 Tamże, s. 533.

${ }^{60}$ Tamże.
} 
zumiejącej siebie duchowej (boskiej) prawdy w jej wolności"61. Estetyczny ogląd idei, wcielenia nieskończoności w skończoność nie jest jednak dla rozumu ostatecznością, ponieważ filozofia znosi także ten ogląd. W zasadzie Hegel zdaje sobie sprawę, że moment najwyższy sztuki został przekroczony zarówno przez religię, jak i przez myśl i refleksję. Sztuka przestała być najwyższą potrzebą ducha. Ciągle jednak może się rozwijać. Balthasar stwierdza: „Tutaj, jeżeli gdziekolwiek, ważność posiada sentencja Heglowska o sowie Minerwy, która wylatuje o zmierzchu - i wymyśla estetykę" 62 .

Wydaje się, że najważniejszym momentem w rozważaniach na temat chwały w filozofii idealistycznej jest idea, że ,jeżeli wydarza się w człowieku myślenie absolutne, przebiega przezeń oś bytu, jego myślenie ujmuje w sobie prostą całość. Dlatego może wznosić »królestwo czystego myślenia «, zaś »królestwo to jest prawdą samą w sobie i bez osłony «, zatem »przedstawieniem Boga, takiego, jakim jest w swojej wiecznej istocie przed stworzeniem natury i skończonego ducha «"63.

Pozostaje jednak pytanie, czy Bóg ten jest rzeczywisty, czy jedynie wymyślony. Balthasar uważa, że podobnie jak u Schellinga trudno ten problem rozstrzygnąć. Pojęcie bytu realnego może się bowiem pojawić jedynie jako przeciwstawne w stosunku do ducha. W logice heglowskiej byt, który jest podstawą procesu myślenia, okazuje się przecież nicością, aby zostać zapośredniczony w stawaniu się i pojawić się jako pojęcie. Metafizyka ducha i bytu rozwija się w ramach kantowskiego rozróżnienia pojęcia i naoczności tego, co ogólne i szczegółowe, które „w obrębie jednoznaczności nie do przebycia są w odniesieniu do siebie mate-

\footnotetext{
${ }^{61}$ Tamże.

62 Tamże, s. 534.

${ }^{63}$ Tamże.
} 
rią i formą" ${ }^{64}$. Balthasar uważa, że z myślenia Hegla wypływają ostatecznie ateistyczne wnioski. Heglowska „droga w sposób niepowstrzymany i logiczny wiedzie od logicznej jednoznaczności (»ogólność«) lub od logicznego materializmu do materializmu przyrodoznawczego. A ponieważ człowiek w swoim własnym myśleniu posiada całościowe pojęcie rzeczywistości, nie istnieje żaden powód, aby nie wyciągnąć ateistycznych wniosków lewicy heglowskiej" ${ }^{65}$. Wprawdzie niebezpieczeństwo materializmu pojawiło się w filozofii Karola Marksa, ale zasadnicza konkluzja związana z myślą Heglowską zmierzała do wydobycia jeszcze raz relacji pomiędzy myślą chrześcijańską a refleksją filozoficzną. Dlatego też Balthasar napisze: ,Jak u Hölderlina, tak u Hegla chrześcijaństwo zniesie się w momencie wszechobecnej kenozy bytu, w której dla obu wydarzy się niedościgniona »wspaniałość « rzeczywistości. U Hegla zatem nigdzie bardziej nie można poszukiwać chwały niż w totalności absolutnego ducha. Myślenie absolutne wypromieniowuje ją w porównywalnej z Leibnizem triumfalności" 66 .

\footnotetext{
${ }^{64}$ Tamże, s. 535.

${ }^{65}$ Tamże.

${ }^{66}$ Tamże, s. 522.
} 
- 


\section{Zakończenie}

Balthasara ciągle inspirowało pytanie o ponadhistoryczny wymiar ludzkiego myślenia i działania, o stosunek tego, co ludzkie, ziemskie, do tego, co chrześcijańskie, nadprzyrodzone. Był przekonany, że zachodni humanizm, od filozofii greckiej do niemieckiego idealizmu, do klasycznych form kultury Zachodu, jawił się jako jedność, którą trzeba nieustannie odkrywać i stale na nowo tworzyć i doskonalić. Zdawał sobie jednocześnie sprawę z faktu, że owa jedność jest ciągle zagrożona przez różne nurty myślowe, przez rozwijający się sekularyzm i eliminowanie myśli chrześcijańskiej z przestrzeni europejskiego życia społecznego i kulturowego. Nie ulega wątpliwości, że rozważania Balthasara na temat relacji pomiędzy refleksją chrześcijańską a myślą filozoficzną trzeba umieścić w kontekście związku ogólnie pojętej filozofii i teologii. Balthasar, pytany kiedyś o ich wzajemny stosunek, wyjaśniał go, wskazując na trzy fazy ludzkich koncepcji myślowych, które postrzegał przede wszystkim jako próby zrozumienia sensu bytu i rzeczywistości.

Po pierwsze: przed pojawieniem się Chrystusa filozofia była teologią, a jej najważniejszym zadaniem było poszukiwanie Absolutu przez człowieka. Jeśli umiłowanie mądrości prowadziło do konieczności zadania pytania i próby zrozumienia, czym jest 
byt, to wyzwaniem teologii było poszukiwanie odpowiedzi na pytanie, czy człowiek przy swoich ograniczonych możliwościach potrafi znaleźć nieskończonego Boga.

Po drugie: w refleksji chrześcijańskiej istotną rolę odgrywają zdolność i możliwości myślącego podmiotu oraz świadomość, że teologia bezpośrednio i w sposób konieczny niesie w sobie filozofię. Wyrazem treści teologicznych mogą być różne formy filozofii, których cechą charakterystyczną jest zdolność bycia ujmowanymi na różne sposoby. Przejście od myślenia obrazowego i mitycznego do filozoficznego charakteryzuje w sposób wyraźny opisy zawarte w Piśmie Świętym.

Po trzecie: po dokonaniu przez Chrystusa dzieła Odkupienia świata, a w nim człowieka, pojawiają się trudności z określeniem relacji filozofii i teologii, ponieważ w Chrystusie zrozumienie sensu bytu zostało w pełni wyjaśnione - sam Chrystus jest tym sensem.

Tym samym „to, co w filozofii chrześcijańskiej na przestrzeni dziejów było i jest żywe, zawdzięcza swoje życie wierze i teologii. Tylko jeżeli wielcy myśliciele chrześcijańscy są teologami, są także wielkimi filozofami. Decyzja chrześcijańska zajmuje u nich to miejsce, w którym myśliciele niechrześcijańscy decydują się na Absolut, na swojego boga. Filozofowie chrześcijańscy sami z siebie stają się teologami, jeśli są myślicielami z »ostatecznej namiętności «"67. W powołaniu filozofa Balthasar podkreślał rolę troski o to, by strzec poprawności myślenia. W zasadzie przed każdym człowiekiem, a zwłaszcza religijnym, stawiał szczególne zadanie bycia strażnikiem filozofii ${ }^{68}$. Zadanie to na przestrzeni

${ }^{67}$ OZFK, s. 21.

${ }^{68}$ Pośród strażników filozofii Balthasar dostrzega postać Wiktora Sołowjowa i umieszcza go obok Johanna Georga Hamanna. Według Balthasara, „Sołowjow lepiej niż dzisiejsi ewolucjoniści wiedział, jak głębię idealizmu niemieckiego zmieścić w wymiarach swej myśli ekumenicznej”; tenże, 
wieków polega nie tylko na dbałości o poprawność myślenia teologicznego i konieczności wzajemnego przenikania się filozofii i teologii, ale jest przede wszystkim określeniem celu prawdziwej filozofii chrześcijańskiej, czyli przywracaniem zsekularyzowanemu myśleniu jego prawdziwej postaci. Tę zsekularyzowaną formę myślenia chrześcijańskiego widzi Balthasar przede wszystkim $\mathrm{w}$,twierdzeniach pozornie czystej filozofii, np. w gnozie, w heretyckiej mistyce średniowiecza od Eriugeny do Böhmego, czy wreszcie także w idealizmie od Kanta do Hegla i w całkowicie przesiąkniętej chrześcijańskimi motywami filozofii życia i filozofii egzystencjalnej" ${ }^{69}$.

Balthasar opisuje postawy człowieka przedstawione w literaturze, sztuce, filozofii i teologii nie tylko z czysto historycznego, neutralnego punktu widzenia, lecz po to, aby krytycznie spojrzeć na umiejętność jego otwarcia się na Transcendencję, i ukazuje $\mathrm{w}$ ten sposób niejako konieczność zobiektywizowania tych postaw. Otwarcie się człowieka na eschaton, na to, co ostateczne, staje się rzeczywiście jego fundamentalnym zadaniem. $\mathrm{Z}$ metodycznego punktu widzenia centrum rozważań stanowi świadomość samoprzedstawienia się podmiotu w jego konkretnej egzystencji. Dopiero z tego centrum można budować całościowy obraz postawy eschatologicznej. W tym sensie krytyczne spojrzenie Balthasara na idealizm należy rozumieć jako krytykę przeprowadzoną niejako od wewnątrz, wychodzącą od tego, co stanowi centrum. Objawienie ostatecznego celu jest w pierwszym rzędzie

Retrospektywa, w: OMD, s. 60. Balthasar uważał, że Sołowjow „wypowiada swą dojrzałą opinię wyrażającą sprzeciw wobec kantowsko-heglowskiego formalizmu, zapewniając miejsce dla nieistniejącej dotąd w sposób świadomy dyscypliny estetyki teologicznej, albo nadając jej kształt przynajmniej w ogólnych zarysach. Jest on »jedynym rosyjskim pisarzem, który pozostawił nam estetykę«"; CH II/1/2, s. 289.

${ }^{69}$ OZFK, s. 22. 
możliwe w podejściu do konkretnego zdarzenia, życia konkretnego podmiotu, a nie w abstrakcyjnym ujęciu „obiektywnych” danych na temat jakiegoś zdarzenia. Osąd ten dotyczyć miał wskazania ostatecznego niepowodzenia wszelkiej myśli o charakterze czysto immanentnym. Eschatologiczna postawa niemieckiej duszy postrzegana będzie ostatecznie jako tragedia; jeśli bowiem człowiek, a z nim wszystko, co jest bytem skończonym, nie może w swej postawie osiągnąc tego, co nieskończone, element nieskończony musi sam w jakiś sposób dać się temu, co skończone. Takie myślenie wymaga przyjęcia założenia wstępnego. Bóg jako eschaton, dający się i uprzedzający wszelką postawę, jawi się jako zasadnicza myśl Balthasarowskiej eschatologii.

Jeśli popatrzeć na źródła myśli idealistycznej, to w pierwszym rzędzie idealizm pozostaje dla Balthasara wykładnią filozofii Kantowskiej, w której rozumienie całości rzeczywistości musi rozwinąć się z transcendentalnej struktury aktu myślącego i działającego podmiotu. Akt ten zastępuje obiektywny system świata i sam staje się jego sensem i zasadą. Widziany zaś jako Absolut, bądź go przynajmniej zakładający, pozostaje bardzo ważnym punktem odniesienia. Ujawnia się w ten sposób powrót do człowieka jako centrum wszelkiego pojmowania i rozumienia, a tym samym odkrycie na nowo podmiotowości. Balthasar zdaje sobie sprawę, że „nawet ogromne zbliżenie systemu idealistycznego do myśli Plotyna (jako formy ostatecznej antyku) nie jest powrotem do zdecydowanej postawy otwartego oczekiwania, która była u Plotyna wiodąca, raczej ostatecznie wszystko rozstrzyga się w decyzji rozumienia chrześcijaństwa (w epoce postchrześcijańskiej) jako czystej filozofii, zatem ostatecznie jako tego, co leży w granicach możliwości człowieka, dziejów i kultury. Także (znacznie osłabiona) szansa podjęcia ostatecznej decyzji 
u Kuzańczyka: prawdopodobieństwo czy wiedza absolutna zdecydowanie rozstrzygnięta została na korzyść wiedzy absolutnej"70.

Filozoficzne i teologiczne przedstawienie niemieckiego idealizmu przez Balthasara wydaje się koncentrować wokół filozofii podmiotu rozumianego prawie paradygmatycznie, ujmowanego za pomocą takich pojęć, jak „podmiotowość”, „racjonalność” czy też „wolność samookreślenia”. Balthasar wyraźnie zmierza do krytyki idealizmu i jego subiektywnych prób opisu rzeczywistości, a szczególnie relacji jednostki do wiecznego przeznaczenia. Zbliża się natomiast ku obrazom mitycznym, założeniom estetycznym i konieczności teoriopoznawczego skoku ku jawiącej się wyraźnie postaci Bożej w Jezusie Chrystusie ${ }^{71}$. Niemiecka filozofia ducha widziana jest przez Balthasara jako postawa, w której skończony duch człowieka nie potrafi sam z siebie osiągnąc swojego celu ostatecznego. Jedynie sam Bóg jako eschaton jest tym, który może to dążenie wypełnić.

Balthasar jest przekonany, iż idealizm niemiecki należy przezwyciężyć, ale jednocześnie zachować. Zachować, ponieważ wyznacza on początek właściwej duchowej drogi w przyszłość ${ }^{72}$. Ujęcie Balthasara prowadzi ostatecznie do odwrócenia historycznego porządku myśli idealistycznej. Nieskończony duch człowieka winien za wszelką cenę ująć to, co nieskończone, ale Bóg jako eschaton, który wszystko uzasadnia i buduje, jest punktem wyjścia.

${ }^{70} \mathrm{CH}$ III/1/2, s. 498.

71 Por. M. Schulz, Sein und Trinität: systematische Erörterungen zur Religionsphilosophie G. W. F. Hegels im ontologiegeschichtlichen Rückblick auf J. Duns Scotus und I. Kant und die Hegel-Rezeption in der Seinsauslegung und Trinitätstheologie bei W. Pannenberg, E. Jüngel, K. Rahner und H.U. von Balthasar, EOS-Verlag, St. Ottilien 1997, s. 688.

72 Por. M. Bondeli, Mystische Potentialität. Hans Urs von Balthasar über den Weg von Kant zu Hegel, w: Letzte Haltungen. Hans Urs von Balthasars „Apokalypse der deutschen Seele” - neu gelesen, hrsg. von B. Hallensleben, G. Vergauwen, Academic Press-Paulusverlag, Freiburg 2006, s. 139. 
Filozofia idealizmu niemieckiego osiada często na „mieliźnie” panteizmu, nie ma w niej miejsca na miłość. Heglowskie pojęcie ducha jako „bycie w sobie i dla siebie” jest zaprzeczeniem miłości, jest zastąpieniem miłości przez rozum, który poszukuje ostatecznie sam siebie. W filozofii Hegla Balthasar dostrzega wprawdzie niejako inną możliwość refleksji, nieskończenie bliską myśli chrześcijańskiej, z której jednak chrześcijanin nie może skorzystać. Balthasar jest przekonany, że w Heglowskich próbach zbudowania relacji myśli idealistycznej i chrześcijańskiej ta ostatnia zostaje wyraźnie zdominowana i przejęta przez filozofię idealistyczną ${ }^{73}$.

Przywołując myślenie Jaspersa, Balthasar stwierdza dość radykalnie: „Kiedy Jaspers łączy ideę miłości z ideą prawdy i tę ostatnią czyni podstawą komunikacji międzyludzkiej, owo pojęcie zawodzi go w decydującym momencie: w momencie otwarcia prawdy doczesnej na prawdę wieczną. Z Bogiem nie ma komunikacji, rozmowy, wymiany"74. Filozofii niemieckiej Balthasar potrafi wytknąć braki nie tylko o charakterze filozoficznym, spekulatywnym, ale także odnoszące się do doświadczenia religijnego i odczuwania ludzkiego ducha tworzącego świat poezji i kultury. „To, czego zupełnie brakuje filozofii niemieckiej, to metafizyka uwielbienia, modlitwy, słuchania, kontemplacji jako otwarcia się i przyjęcia. Najważniejszą postawą pozostaje postawa wiedzy, lub co najwyżej czynu, obie jednak trwają skrępowane w działającym i wytwarzającym podmiocie. Zastąpienie "słowa na początku « »czynem na początku « $\mathrm{i}$ »wiedzą absolutną " poza religią skazuje Niemca na coraz gęstszą, niedostępną i przez to także coraz mniej owocną samotność, która w końcu staje się »siódmą samotnością "Nietzschego. Niemcy nie chcą się modlić. Są narodem po-

${ }^{73}$ Por. P. Henrici, O filozofii Hansa Ursa von Balthasara, w: PW 1, s. $163-164$.

${ }^{74}$ H.U. von Balthasar, Humanizm chrześcijański, w: PW 1, s. 93. 
etów i myślicieli, a nie narodem świętych. Powinni nim być jak każdy naród w zamierzeniu Boga. Ale oni ducha uczynili bogiem i dlatego odmówiono im ducha Bożej miłości"75.

Idealizm jest dla Balthasara wizją całości człowieka i dlatego też jej apokalipsą. Fichte i Schelling prezentują ją jako wizję idei ${ }^{76}$, podczas gdy Novalis, Hölderlin, Schiller, Goethe i Hegel pojawiają się jako reprezentanci wizji przedstawionej za pośrednictwem życia ${ }^{77}$. Balthasar zdawał sobie sprawę, że dla idealistów skończoność była $\mathrm{w}$ jakiś sposób tymczasowością, która w procesie myślenia i rozwoju człowieka i świata miała przyjąć inną formę, miała zostać wyniesiona w nieskończoność Absolutu. Zarówno dla Fichtego, jak i Schellinga skończoność była jedynie pewnego rodzaju punktem wyjścia. „U Fichtego to, co skończone, było na początku tylko materiałem, w oparciu o który duch miał zdobyć właściwą sobie nieskończoność. Później Fichte zaczął uznawać również duch ludzki za skończony i z powodu tejże skończoności pozwalał, aby ten »mistycznie« rozbijał się o nieskończoność Boga - jak homunkulus o wóz Galatei"78. Myślenie tożsamościowe Schellinga było wprawdzie próbą dostrzegania jedności świata skończonego i nieskończonego. Ostatecznie jednak, nawet jeśli Schelling widział element boski w samej skończoności świata, to

75 Tamże.

${ }^{76}$ Por. AP I, s. 137.

77 Por. tamże, s. 235.

${ }^{78}$ H.U. von Balthasar, Filozofia Martina Heideggera z punktu widzenia katolicyzmu, w: PW 1, s. 118. „Teza ta została przedstawiona najwyraźniej w książce Heideggera o Kancie i da się sformułować następująco: ludzki duch przez to jest duchem, że przewyższa poziom zwykłego bycia, że w swojej istocie jest transcendencją i że rzeczy tego świata naświetlone z takiego dystansu stają się dla niego przedmiotami poznania. Owo przewyższenie, które jako takie samo nie jest byciem, lecz poniekąd próżnią, jest wtargnięciem nicości w to bycie. Im bardziej więc bycie zbliża się do nicości, to znaczy im bardziej jest skończone, tym bardziej jest ono duchowe”; tamże, s. 117-118. 
216 Hans Urs von Balthasar wobec idealizmu niemieckiego

umieszczając nicość w samym Bogu, sprawił, że sam Bóg „rozpadł się w demonicznym dualizmie: w Bogu jest coś wiecznie nieboskiego, pewna ciemna otchłań"79.

Balthasar bronił z jednej strony skończoności świata, z drugiej widział konieczność wyjścia poza świat skończony. Dostrzegał jego konieczny związek z Bogiem i jednocześnie daleki był od absolutyzowania samej skończoności. Chrześcijańskie podejście podpowiadało mu postawę, w której ,jako chrześcijanie możemy spotykać się z pozytywnością skończoności (przy całej jej trwałej negatywności) równie dobrze w duchowych i przepełniających nas doświadczeniach egzystencji: w miłości doświadczamy niedającej się z niczym porównać szczególności istoty skończonej mimo całego bólu jej ograniczenia, które przeszkadza nam stać się w pełni jednością. W sztuce - cudu jednorazowego udanego przedstawienia »skończenie doskonałej « postaci. W postępowaniu etycznym - obciążonej wiecznością wyjątkowości chwili"80. Ludzkie spoglądanie w górę otwiera z kolei na Tego, który „patrzy na nas nieustannie z otchłani Absolutu i któremu chodzi o nas, o ciebie i o mnie - w naszej jedyności" ${ }^{81}$. Totalność heglowskiego ducha absolutnego wchłaniała wszelką skończoność, która przecież stanowiła także materiał dla budowy i rozwoju ducha nieskończonego. Balthasar zdawał sobie sprawę, że Hegel chciał uniknąć dowartościowania przedmiotowego świata. Zmieniając

${ }^{79}$ Tamże.

${ }^{80}$ Tamże, s. 126. „Duch jako taki jest skończonością, a skoro duch jest właściwym, prawdziwym byciem, to Heidegger może uczynić własnym zdanie Hegla, według którego (właściwe) bycie i nicość pokrywają się. Takie Heideggerowskie zrównanie ducha i skończoności nie jest jednak w myśleniu czasów współczesnych jakimś głazem narzutowym, ale raczej konsekwentnym zwornikiem całego szeregu umysłowych dążeń XIX i XX wieku, które zaczynają się wraz z odwrotem od idealistycznej filozofii Fichtego, Schellinga i Hegla"; tamże, s. 118.

${ }^{81}$ Tamże. 
pojęcie bytu absolutnego w proces, ukazał ducha jako dynamiczną zasadę, która przechodzi przez wszystkie poziomy świata skończonego, wciela się, pojmując samą siebie, i wyzwala się tym samym z ograniczoności świata. Jednak to skończoność była materiałem do zbudowania pełni nieskończonego boskiego ducha, ale ostatecznie została unicestwiona i pozbawiona wartości.

Wreszcie Balthasar wypowiada zdecydowane słowa oceny filozofii idealistycznej: „Katastroficznie przebiega inna linia, mianowicie filozofii ducha, później filozofii transcendentalnej. (...) Zapomnienie o bycie mści się u Kanta jako utrata bytu, gdzie pobożny bezpośredni dostęp do Boga utrzymuje się jeszcze w moralnym, autonomicznym ujęciu woli przez siebie, aby następnie, co nie mogło nie nastąpić, stać się tytanicznym bezpośrednim sięgnięciem po Boga przez ja formalne (początkowo filozofia Fichtego), które uzyskało w swojej wewnętrznej nieskończoności punkt widzenia Boga poprzez świat" ${ }^{\prime 2}$. Podobna ocena dotyczy rozumienia pojęcia chwały: „Tym samym »chwała « nie tylko stoczyła się do poziomu piękna świata, lecz stała się bezbożną własną chwałą ducha, który obejmuje rządy nie tylko nad sobą, ale również nad całą pozostałą rzeczywistością. Metafizyka, a wraz z nią metafizyczna miłość sięgnęły tutaj końca. Pozostały w najlepszym wypadku formy zastępcze wewnątrzkosmicznej miłości oraz miłości międzyludzkiej" 83. Także wobec myśli estetycznej pojawiają się w pismach Balthasara zdecydowane słowa: „To, co w przestrzeni metafizyki zasłużyło na nazwę »chwały «, rozwiało się; z bytu już nic nie promieniuje; piękno przepędzone ze sfery transcendentalności ograniczone zostało do sfery wewnątrzświatowej, gdzie spoczywają tylko objęte jednoznacznością, czekające na ujarzmienie napięcia i sprzeczności: tylko pod tym warunkiem

\footnotetext{
${ }^{82} \mathrm{CH}$ III/1/2, s. 583.

83 Tamże.
} 
staje się możliwa estetyka jako nauka ścisła. Ta nie należy już do przedmiotu naszych dociekań, które za przedmiot wzięły »chwałę", nie zaś wymiar wewnątrzświatowy piękna (które może się wznieść do »wzniosłości «, a może sięgać również do brzydoty)"84.

W ten sposób niemiecka filozofia ducha była dla Balthasara z jednej strony owocem chrześcijaństwa, z drugiej niosła ze sobą wielkie zagrożenie. Idealizm widział zarówno filozofię, jak i teologię w ideale wiedzy absolutnej, tymczasem zgodnie z myśleniem chrześcijańskim integracja filozofii i teologii oparta jest na wolnych czynach wolnego Boga, które są jednocześnie objawieniem najwyższego absolutnego rozumu ${ }^{85}$. Balthasar zdaje sobie sprawę, że aby dokonać przełamania filozofii idealistycznej, trzeba wskazać jej przeciwległy kraniec, to znaczy punkt, w którym następuje otwarcie się na to, co ostateczne, co wyrywa podmiot z jego skończoności i ograniczoności. W konfrontacji idealizmu niemieckiego z chrześcijańskim sposobem myślenia wzajemne przenikanie się teologii i filozofii w sposób wyraźny ukazuje, że dialektyka idealizmu odsłania w podmiocie refleksyjnym absolutny dualizm, nie wskazując możliwości skutecznego pokonania tkwiących w nim napięć i sprzeczności. Wywodzenie filozofowania jedynie z postaw subiektywnych, a nie z obiektywnego bytu, prowadzi do kreślenia horyzontu filozoficznego wyłącznie z punktu widzenia samego podmiotu i gubi przedmiotowe uwarunkowania, które w jakiś sposób mogą kształtować sam byt ${ }^{86}$. Nadzieją, ale i przestrogą pozostaje ciągle postawa prometejska, w której Balthasar zdawał się odnajdywać własną twórczość i samego siebie. W cie-

${ }^{84}$ Tamże, s. 543.

85 Por. CH II/1/2, s. 298.

${ }^{86}$ Por. M. Urban, W poszukiwaniu estetyki. Hans Urs von Balthasar czyta Włodzimierza Sołowjowa, w: Pytając o prawdę rzeczywistości. Księa jubileuszowa z okazji 70. rocznicy urodzin prof. dr. hab. Stanistawa Bafii, red. M. Pawliszyn, Tuchów 2015, s. 163-174. 
kawych słowach analizował Kunst der Fuge Jana Sebastiana Bacha, pisząc, iż wielu „wspomina czas, kiedy z wiedzy wszystkich wypływało to, co tworzyła myśl, a rysy wszystkich nadawano postaci. Mistrza w ogóle nie nazywano wówczas z imienia, a jednak jego obraz tryumfalnie niesiono ulicami. Z początkiem czasów, od których sztuka zazwyczaj nazywana jest romantyczną, zaczęto patetycznie zafałszowywać ów stosunek, jaki z dawien dawna uważany był za zgodny z istotą sztuki: stosunek artysty do społeczeństwa. Nie chciał on już sławy swego dzieła, lecz pochwały samego siebie. Samotnie wspina się do nieba, aby skraść boski ogień, nie jako posłaniec, ale jako zuchwalec, który obdarowuje. Ponieważ zaś wzniósł się ponad wspólnotę na przekór, a nie jako modlitwa wszystkich, został spętany przez swoje wyizolowanie i przez ambicję oszukany co do swoich najlepszych praw. Dym jego ognia był większy niż jego jasność" 87 . Współczesny czytelnik pragnący bliżej poznać twórczość von Balthasara często staje bezradny wobec jej ogromu. Myślenie Balthasara obejmuje nie tylko filozofię i teologię, ale również muzykę, literaturę, sztukę i łączy w sobie różne sfery. Pośród wielu doświadczeń związanych z „dotykaniem" otaczającego nas świata Balthasarowi bliskie są dwa przeżycia: estetyczne i religijne. Oba wykazują pewne analogie. Są skierowane ku temu, co obiektywne, i oscylują między dwoma biegunami: tym, co zewnętrzne, i tym, co wewnętrzne. Oba wprawdzie nastawione są na konkret, ale odsyłają jednocześnie do tego, co niewidzialne i trudne do ogarnięcia.

Drogi filozofa i chrześcijanina ostatecznie się przecinają. W każdym czasie filozof wykracza ze swoją myślą poza granice codzienności. Niedoceniany i chwalony jednocześnie, chce zrozumieć świat i przemienić go w coś wyjątkowego, ale nade wszystko prawdziwego. Ma nadzieję, że w chwilach największych słabości,

${ }^{87}$ H.U von Balthasar, Sztuka fugi, w: PW 2, s. 56-57. 
$220 \quad * \quad$ Hans Urs von Balthasar wobec idealizmu niemieckiego

na pustkowiu swoich ograniczeń, zostanie pochwycony przez to, co absolutne. Chrześcijanin „kroczy od Boga, zanurzając się coraz głębiej w świat, dzieli się jak chleb, w końcu zostaje rozszarpany, jak Orfeusz przez menady. Rozdawanie siebie jest istotą (...), o to jedynie chodzi i to jest celem" $"$.

${ }^{88}$ H.U. von Balthasar, Ziarno pszenicy. Aforyzmy, tłum. J. Ryndak, Wydawnictwo M, Kraków 2004, s. 166. 


\section{Bibliografia}

\section{Hans Urs von Balthasar - teksty źródłowe}

Apokalipsa niemieckiej duszy, w: Pisma wybrane, t. 1: Pisma filozoficzne, wybór i oprac. M. Urban, tłum. M. Urban, D. Jankowska, WAM, Kraków 2006, s. 144-151.

Apokalypse der deutschen Seele. Studien zu einer Lehre von letzten Haltungen, Bd. I: Der deutsche Idealismus (1937), Bd. II: Im Zeichen Nietzsches (1939), Bd. III: Vergöttlichung des Todes (1939). Studienausgabe der frühen Schriften unter der Leitung von A.M. Haas, Johannes Verlag Einsiedeln, Freiburg 1998.

Christlicher Universalismus, w: Verbum Caro (Skizzen zur Theologie I), Johannes Verlag, Einsiedeln 1960, s. 260-275.

Chwała. Estetyka teologiczna I. Kontemplacja postaci, tłum. E. Marszał, J. Zakrzewski, WAM, Kraków 2008.

Chwała. Estetyka teologiczna II/1. Modele teologiczne, cz. 1: Od Ireneusza do Bonawentury, tłum. E. Marszał, J. Zakrzewski, WAM, Kraków 2008.

Chwała. Estetyka teologiczna II/1. Modele teologiczne, cz. 2: Od Dantego do Peguy, tłum. E. Marszał, J. Zakrzewski, WAM, Kraków 2008. 
$222 \quad$ Hans Urs von Balthasar wobec idealizmu niemieckiego

Chwata. Estetyka teologiczna III/1. Metafizyka, cz. 1: Starożytność, tłum. L. Łysień, WAM, Kraków 2011.

Chwała. Estetyka teologiczna III/1. Metafizyka, cz. 2: Nowożytność, tłum. L. Łysień, WAM, Kraków 2013.

Cordula albo o świadectwie chrześcijanina, tłum. F. Wycisk, WAM, Kraków 2002.

Das Ganze im Fragment. Aspekte der Geschichtstheologie, Benziger, Einsiedeln 1963.

Das christliche Jahr [in Bildern von Richard Seewald und Worten von Hans Urs von Balthasar], Josef Stocker, Luzern 1944.

Die Gottesfrage des heutigen Menschen, Herold, Wien 1956.

Duch i ogień. Rozmowa Michaela Albusa z Hansem Ursem von Balthasarem, w: O moim dziele, tłum. M. Urban, Wydawnictwo M, Kraków 2004, s. 85-107.

Epilog, tłum. J. Zychowicz, WAM, Kraków 2010.

Ewangelia i filozofia, w: Pisma wybrane, t. 1: Pisma filozoficzne, wybór i oprac. M. Urban, tłum. M. Urban, D. Jankowska, WAM, Kraków 2006, s. 66-75.

Filozofia Martina Heideggera z punktu widzenia katolicyzmu, w: Pisma wybrane, t. 1: Pisma filozoficzne, wybór i oprac. M. Urban, tłum. M. Urban, D. Jankowska, WAM, Kraków 2006, s. 117-126.

Geeinte Zwienatur. Eine philosophische Besinnung, Manuskript, Archiv Hans Urs von Balthasar, Basel.

Geschichte des eschatologischen Problems in der modernen deutschen Literatur, Johannes Verlag Einsiedeln, Freiburg $1998^{2}$.

Hans Urs von Balthasar przedstawia siebie, w: O moim dziele, tłum. M. Urban, Wydawnictwo M, Kraków 2004, s. 9-14.

Humanizm chrześcijański, w: Pisma wybrane, t. 1: Pisma filozoficzne, wybór i oprac. M. Urban, tłum. M. Urban, D. Jankowska, WAM, Kraków 2006, s. 85-99.

Jeszcze jedno dziesięciolecie, w: O moim dziele, tłum. M. Urban, Wydawnictwo M, Kraków 2004, s. 67-78. 
Karl Barth. Darstellung und Deutung seiner Theologie, Hegner, KölnOlten 1951.

Klarstellungen. Zur Prüfung der Geister, Herder, Freiburg 1971.

Kosmische Liturgie. Höhe und Krise des griechischen Weltbilds bei Maximus Confessor, Herder, Freiburg 1941.

Krótki przewodnik po moich książkach, w: O moim dziele, tłum.

M. Urban, Wydawnictwo M, Kraków 2004, s. 15-33.

O moim dziele, tłum. M. Urban, Wydawnictwo M, Kraków 2004.

Origenes. Geist und Feuer. Ein Aufbau aus seinen Werken, Otto Müller, Salzburg 1938.

O zadaniach filozofii katolickiej w czasach współczesnych, tłum. M. Urban, WAM, Kraków 2003.

Pisma wybrane, t. 1: Pisma filozoficzne, wybór i oprac. M. Urban, tłum. M. Urban, D. Jankowska, WAM, Kraków 2006.

Pisma wybrane, t. 2: Pisma z zakresu sztuki i religii, wybór i oprac. M. Urban, tłum. M. Urban, D. Jankowska, WAM, Kraków 2007.

Prawda jest symfoniczna, tłum. I. Bokwa, Poznań 1998.

Prüfet alles, das Gute behaltet. Ein Gespräch mit Angelo Scola, Johannes Verlag Einsiedeln, Freiburg 2001.

Regagner une philosophie à partir de la théologie, w: Pour un philosophie chrétienne. Philosophie et théologie, Namur, Paris 1983, s. $175-187$.

Retrospektywa, w: O moim dziele, tłum. M. Urban, Wydawnictwo M, Kraków 2004, s. 35-65.

Rozwój idei muzycznej, w: Pisma wybrane, t. 2: Pisma z zakresu sztuki i religii, wybór i oprac. M. Urban, tłum. M. Urban, D. Jankowska, WAM, Kraków 2007, s. 25-53.

Spiritus Creator (Skizzen zur Theologie III), Johannes Verlag, Einsiedeln 1967.

Sponsa Verbi (Skizzen zur Theologie II), Johannes Verlag, Einsiedeln 1960.

Sur les Conditions d'une Culture, „La Revue de Culture Européenne” 1954, nr 4, s. 11-21. 
$224 \quad$ Hans Urs von Balthasar wobec idealizmu niemieckiego

Teodramatyka, t. I: Prolegomena, tłum. M. Mijalska, M. Rodkiewicz, W. Szymona, Wydawnictwo M, Kraków 2005.

Teodramatyka, t. II: Osoby dramatu, cz. 1: Człowiek w Bogu, tłum. W. Szymona, Wydawnictwo M, Kraków 2006.

Teologia dziejów. Zarys, tłum. J. Zychowicz, Kraków 1996.

Teologika, t. I: Prawda świata, tłum. J. Zychowicz, WAM, Kraków 2004. Teologika, t. II: Prawda Boga, tłum. J. Zychowicz, WAM, Kraków 2004. Teologika, t. III: Duch Prawdy, tłum. J. Zychowicz, WAM, Kraków 2005. Unser Auftrag: Bericht und Entwurf, Johannes Verlag, Einsiedeln 1984. Verbum Caro (Skizzen zur Theologie I), Johannes Verlag, Einsiedeln 1960.

Wiarygodna jest tylko miłość, tłum. E. Piotrowski, WAM, Kraków 2002. Ziarno pszenicy. Aforyzmy, tłum. J. Ryndak, Wydawnictwo M, Kraków 2004.

Pełna bibliografia dzieł Hansa Ursa von Balthasara znajduje się w: Hans Urs von Balthasar, Bibliographie 1925-2005. Neu bearbeitet von Cornelia Capol und Claudia Müller, Johannes Verlag Einsiedeln, Freiburg 2005, oraz w najbardziej aktualnej wersji elektronicznej na stronie http://www.johannes-verlag.de/jh_huvb_ bibliographie.pdf.

\section{Wybrane opracowania twórczości Hansa Ursa von Balthasara}

Albus M., Die Wahrheit ist die Liebe: zur Unterscheidung des Christlichen nach Hans Urs von Balthasar, Herder, Freiburg-Breisgau 1976.

Baatz U., Ein Anstoß zur „Abendländischen Eschatologie”: Hans Urs von Balthasars „Apokalypse der deutschen Seele”, w: Abendländische Eschatologie. Ad Jacob Taubes, hrsg. von 
R. Faber, E. Goodmann-Thau, Th. Macho, Königshausen und Neumann Verlag, Würzburg 2001, s. 321-329.

Bauer E.J., Hans Urs von Balthasar (1905-1988): Sein philosophisches Werk, w: Christliche Philosophie im katholischen Denken des 19. und 20. Jahrhunderts, Bd. 3: Moderne Strömungen im 20. Jahrhundert, hrsg. von E. Coreth, W.M. Neidl, G. Pfligersdorffer, Verlag Styria, Graz 1990, s. 285-304.

Bieler M., Meta-antropologia e cristologia. A riguardo della filosofia di Hans Urs von Balthasar, „Communio. Rivista Internazionale di Teologia e Cultura" 1991, nr 117, s. 107-121.

Bokwa I., Trynitarno-chrystologiczna interpretacja eschatologii $w$ ujeсіu Hansa Ursa von Balthasara, Wydawnictwo Diecezji Radomskiej AVE, Radom 1998.

Bollnow O.F., Hans Urs von Balthasar: Apokalypse der deutschen Seele. 2. und 3. Bd., „Die Literatur” 40 (1937/38), s. 183n., oraz 41 (1938/39), s. 761-763.

Bondeli M., Das Anfangsproblem bei Karl Leonhard Reinhold. Eine systematische und entwicklungsgeschichtliche Untersuchung zur Philosophie Reinholds in der Zeit von 1789 bis 1803, V. Klostermann, Frankfurt am Main 1995.

Bondeli M., Mystische Potentialität. Hans Urs von Balthasar über den Weg von Kant zu Hegel, w: Letzte Haltungen. Hans Urs von Balthasars „Apokalypse der deutschen Seele” - neu gelesen, hrsg. von B. Hallensleben, G. Vergauwen, Academic Press-Paulusverlag, Freiburg 2006, s. 132-158.

Brugnoli A., Hans Urs von Balthasar. La spontaneità delle cose, Casa Editrice Leonardo da Vinci, Roma 2001.

Disse J., Metaphysik der Singularität. Eine Hinführung am Leitfaden der Philosophie Hans Urs von Balthasars, Passagen Verlag, Wien 1996.

Eicher P., Offenbarung. Prinzip neuzeitlicher Theologie, Kösel, München 1977.

Faesi R., „Apokalypse der deutschen Seele”, „Neue Zürcher Zeitung” 1937, nr 1382. 
$226 \quad$ Hans Urs von Balthasar wobec idealizmu niemieckiego

Falconi G., Metafisica della soglia. Sguardo sulla filosofia di Hans Urs von Balthasar, Città Nuova, Roma 2008.

Fisichella R., Rileggendo Hans Urs von Balthasar, „Gregorianum” 71 (1990), nr 3, s. 511-546.

Fisichella R., Solo l'amore è credibile. Una rilettura dell'opera di Hans Urs von Balthasar, Lateran University Press, Città del Vaticano 2007.

Giorgio G., Il raporto di corrispondenza tra filosofia e teologia nel pensiero di Hans Urs von Balthasar, „Ricerche Teologiche” 10 (1991), nr 1, s. 271-296.

Grätzel S., Wahrheit und Spiel: Zur Philosophie und Ethik Hans Urs von Balthasars, w: Gott für die Welt: Henri de Lubac, Gustav Siewerth und Hans Urs von Balthasar in ihren Grundanliegen. Festschrift für Walter Seidel, hrsg. von P. Reifenberg, A. van Hooff, Matthias Grünewald Verlag, Mainz 2001, s. 385394.

Guerriero E., Hans Urs von Balthasar. Monografia, tłum. M. Rodkiewicz, Wydawnictwo M, Kraków 2004.

Haas A.M., Zum Geleit, w: H.U. von Balthasar, Apokalypse der deutschen Seele. Studien zu einer Lehre von letzten Haltungen, Bd. I, Johannes Verlag Einsiedeln, Freiburg 1988, s. XXVXLVIII.

Haas A.M., Hans Urs von Balthasars „Apokalypse der deutschen Seele” im Spannungsbereich von Germanistik, Philosophie und Theologie, w: Hans Urs von Balthasar: Gestalt und Werk, hrsg. von K. Lehmann, W. Kasper, Verlag für christliche Literatur Communio, Köln 1989, s. 62-77.

Haecker T., Tag- und Nachtbücher: 1939 bis 1945, Suhrkamp, Frankfurt 1975.

Hans Urs von Balthasar: Gestalt und Werk, hrsg. von K. Lehmann, W. Kasper, Verlag für christliche Literatur Communio, Köln 1989. 
Hartmann M., Ästhetik als ein Grundbegriff fundamentaler Theologie. Eine Untersuchung zu Hans Urs von Balthasar, EOS Verlag, St. Ottilien 1985.

Henrici P., Hans Urs von Balthasar: Aspekte seiner Sendung, Johannes Verlag Einsiedeln, Freiburg 2008.

Henrici P., O filozofii Hansa Ursa von Balthasara, w: H.U. von Balthasar, Pisma wybrane, t. 1: Pisma filozoficzne, wybór i oprac. M. Urban, tłum. D. Jankowska, M. Urban, WAM, Kraków 2006, s. 153-175.

Hofmann P., Balthasar liest Goethe. Die „Apokalypse der deutschen Seele” als theologische „divina comedia”, w: Letzte Haltungen. Hans Urs von Balthasars "Apokalypse der deutschen Seele” - neu gelesen, hrsg. von B. Hallensleben, G. Vergauwen, Academic Press-Paulusverlag, Freiburg 2006, s. 83-100.

Ide P., Etre et mystère: La philosophie de Hans Urs von Balthasar, Préface de Joseph Doré, Culture et Vérité, Bruxelles 1995.

Jöhri M., Descensus Dei: Teologia della croce nell'opera di Hans Urs von Balthasar, Libreria Editrice della Pontificia Univ. Lateranense, Roma 1981.

Klaghofer-Treitler W., Gotteswort im Menschenwort: Inhalt und Form von Theologie nach Hans Urs von Balthasar, Tyrolia Verlag, Innsbruck 1992.

Köster P., Letzte Haltungen? Hans Urs von Balthasars „Apokalypse der deutschen Seele" - nach über 60 Jahren wieder erschienen, w: P. Köster, Kontroversen um Nietzsche: Untersuchungen zur theologischen Rezeption, Theologischer Verlag, Zürich 2003, s. 365-378.

Krenski T., Hans Urs von Balthasar. Das Gottesdrama, Matthias Gründewald Verlag, Mainz 1995.

Kromer H.M., Hans Urs von Balthasar und Karl Barth im Kontext der „Apokalypse der deutschen Seele”: der Weg zur „Umkehrung”, w: Letzte Haltungen: Hans Urs von Balthasars „Apokalypse der deutschen Seele" - neu gelesen, hrsg. von B. Hal- 
lensleben, G. Vergauwen, Academic Press-Paulusverlag, Freiburg 2006, s. 265-279.

Letzte Haltungen: Hans Urs von Balthasars „Apokalypse der deutschen Seele" - neu gelesen, hrsg. von B. Hallensleben, G. Vergauwen, Academic Press-Paulusverlag, Freiburg 2006.

Lochbrunner M., Analogia caritatis. Darstellung und Deutung der Theologie Hans Urs von Balthasars, Herder, Freiburg-BaselWien 1981.

Löser W., Im Geiste des Origenes: Hans Urs von Balthasar als Interpret der Theologie der Kirchenväter, Josef Knecht, Frankfurt am Main 1976.

Meier H., Frühe Begegnungen mit Hans Urs von Balthasar, w: Letzte Haltungen: Hans Urs von Balthasars „Apokalypse der deutschen Seele" - neu gelesen, hrsg. von B. Hallensleben, G. Vergauwen, Academic Press-Paulusverlag, Freiburg 2006, s. $344-352$.

Moda A., Hans Urs von Balthasar: un'esposizione critica del suo pensiero, Ecumenica Editrice, Bari 1976.

Naduvilekut J., Christus der Heilsweg: Soteria als Theodrama im Werk Hans Urs von Balthasars, EOS Verlag Erzabtei, St. Ottilien 1987.

Nandkisore R., Hoffnung auf Erlösung. Die Eschatologie im Werk Hans Urs von Balthasars, Editrice Pontificia Univ. Gregoriana, Roma 1997.

Nichols A., Scattering the Seed: a Guide through Balthasar's Early Writings on Philosophy and the Arts, T \& T Clark, London 2006.

Oakes T.E., Goethe, Nietzsche and the Encounter with German Idealism, w: Pattern of Redemption: the Theology of Hans Urs von Balthasar, Continuum, New York 1994.

O'Regan C., The anatomy of misremembering: von Balthasar's response to philosophical modernity, t. I: Hegel, Chestnut Ridge, Crossroad Pub. Co, New York 2014. 
Parotto G., Lo sguardo della sibilla. Rivelazione e storia nell'interpretazione balthasariana di Schelling, „Humanitas” 15 (2005), nr 6, s. 1240-1259.

Peterson P.S., Fortschritt und Untergang: die antimoderne Moderne in Hans Urs von Balthasars frühen Schriften, „Kirchliche Zeitgeschichte" 24 (2011), nr 1, s. 225-247.

Peterson P.S., The early Hans Urs von Balthasar: Historical contexts and intellectual formation, De Gruyter, Berlin-Boston 2015.

Piotrowski E., Teodramat. Dramatyczna soteriologia Hansa Ursa von Balthasara, WAM, Kraków 1999.

Quash J.B., „Between the Brutely Given, and the Brutally, Banally Free": Von Balthasar's Theology of Drama in Dialogue with Hegel, „Modern Theology” 13 (1997), nr 3, s. 293-318.

Sachs J.R., Spirit and Life. The Pneumatology and Christian Spirituality of Hans Urs von Balthasar, Hagelloch, Tübingen 1984.

Schindler D.Ch., The Dramatic Structure of Truth: In Dialogue with Hans Urs von Balthasar and Continental Philosophy from Kant to Heidegger, The Catholic University of America, Washington DC 2001.

Schrijver de G., Le merveilleux accord de l'homme et de Dieu. Étude de l'analogie de l'être chez Hans Urs von Balthasar, coll. Bibliotheca Ephemeridum Theologicarum Lovaniensium 63, University Press, Louvain 1983.

Schulz M., Die Logik der Liebe und die List der Vernunft. Hans Urs von Balthasar und Georg Wilhelm Friedrich Hegel, w: Logik der Liebe und Herrlichkeit Gottes. Hans Urs von Balthasar im Gespräch. Festgabe für Karl Kardinal Lehmann zum 70. Geburtstag, hrsg. von W. Kasper, Matthias Grünewald Verlag, Ostfildern 2006.

Schulz M., Sein und Trinität: systematische Erörterungen zur Religionsphilosophie G. W. F. Hegels im ontologiegeschichtlichen Rückblick auf J. Duns Scotus und I. Kant und die Hegel-Rezeption in der Seinsauslegung und Trinitätstheologie bei 
W. Pannenberg, E. Jüngel, K. Rahner und H. U. von Balthasar, EOS-Verlag, St. Ottilien 1997.

Schulz M., Theologen als Philosophen: Karl Rahner und Hans Urs von Balthasar: Zum 100. Geburtstag von Karl Rahner (5. März 1904) und Hans Urs von Balthasar (12. August 1905), „Rivista Teologica di Lugano” IX (2004), nr 1, s. 61-92.

Scola A., Hans Urs von Balthasar - ein theologischer Stil: eine Einführung in sein Werk, Dr. Bonifatius Buch Verlag, Paderborn 1996.

Seubert H., Offenbares Geheimnis und Apokalypse: das religionsphilosophische Erbe des Hans Urs von Balthasar, 1. Teil, „Edith-Stein-Jahrbuch”, Bd. 6, Echter-Verlag, Würzburg 2000, s. 291-306.

Seubert H., Offenbares Geheimnis und Apokalypse: das religionsphilosophische Erbe des Hans Urs von Balthasar, 2. Teil, „Edith-Stein-Jahrbuch", Bd. 7, Echter-Verlag, Würzburg 2001, s. 211-226.

Simon U., Balthasar on Goethe, w: The Antology of Beauty. The Theology of Hans Urs von Balthasar, ed. by J. Riches, T\&T Clark, Edinburgh 1986.

Son-Tae K., Christliche Denkform: Theozentrik oder Anthropozentrik? Die Frage nach dem Subjekt der Geschichte bei Hans Urs von Balthasar und Johann Baptist Metz, Universitätsverlag, Freiburg 1999.

Splett J., Hans Urs von Balthasar: Wahrheit in Herrlichkeit, w: J. Splett, Denken vor Gott: Philosophie als Wahrheits-Liebe, Knecht, Frankfurt am Main 1996, s. 197-220.

Toniolo A., La theologia crucis nel contesto della modernità. Il rapporto tra croce e modernità nel pensiero di E. Jüngel, H. U. von Balthasar e G. W. F Hegel, Pontificio Seminario Lombardo, Roma 1995.

Urban M., W poszukiwaniu estetyki. Hans Urs von Balthasar czyta Włodzimierza Sołowjowa, w: Pytając o prawdę rzeczywistości. Księga jubileuszowa z okazji 70. rocznicy urodzin prof. 
dr. hab. Stanisława Bafii, red. M. Pawliszyn, Tuchów 2015, s. $163-174$.

Wallner K.J., Gott als Eschaton. Trinitarische Dramatik als Voraussetzung göttlicher Universalität bei Hans Urs von Balthasar, Heiligenkreuz Verlag, Wien 1992.

Wierciński A., Hermeneutik der Gabe: Die Wechselwirkung von Philosophie und Theologie bei Hans Urs von Balthasar, w: Logik der Liebe und Herrlichkeit Gottes: Hans Urs von Balthasar im Gespräch: Festgabe für Karl Kardinal Lehmann zum 70. Geburtstag, hrsg. von W. Kasper, Matthias Grünewald Verlag, Ostfildern 2006, s. 350-370.

Wolf J.C., Balthasar und Nietzsche, w: Letzte Haltungen: Hans Urs von Balthasars „Apokalypse der deutschen Seele” - neu gelesen, hrsg. von B. Hallensleben, G. Vergauwen, Academic Press-Paulusverlag, Freiburg 2006, s. 179-213.

Wood R.E., Philosophy, Aesthetics and Theology: A Review of Hans Urs von Balthasar's The Glory of the Lord, „The American Catholic Philosophical Quarterly" LXVII (1993), nr 3, Washington DC, s. 355-382.

Wrann A., Hans Urs von Balthasar als katholischer Hegelkritiker, GRIN Verlag, München 2008; 2013.

Zaborowski H., Katholische Integration. Zum Verhältnis von Philosophie und Theologie bei Hans Urs von Balthasar, w: Die Kunst Gottes verstehen: Hans Urs von Balthasars theologische Provokationen, hrsg. von M. Striet, J.-H. Tück, Herder, Freiburg 2005, s. 28-48.

Zucal S., L'interpretazione teologica di Hegel nel primo Balthasar, „Filosofia oggi” VIII (1985), nr 3, s. 523-548; IX (1986), nr 2, s. 267-304. 


\section{Literatura pomocnicza}

\section{Teksty źródłowe}

Barth K., Die kirchliche Dogmatik, Bd. II/1, Evangelischer Verlag, Zürich 1940.

Cassirer E., Das Erkenntnisproblem in der Philosophie und Wissenschaft der neueren Zeit, Bd. 3: Die nachkantischen Systeme, Wissenschaftliche Buchgesellschaft, Darmstadt 1974.

Faust A., Der Möglichkeitsgedanke. Systemgeschichtliche Untersuchungen, 1. Teil: Antike Philosophie, 2. Teil: Christliche Philosophie, C. Winter, Heidelberg 1931-1932 (reprint Garland Pub., New York 1987).

Fichte J.G., Die Anweisung zum seligen Leben oder Die Religionslehre, Felix Meiner Verlag, Hamburg 2012.

Fichte J.G., Kilka wykładów o powołaniu uczonego, tłum., wstęp i oprac. T. Kupś, Wydawnictwo Naukowe UMK, Torun 2012.

Fichte J.G., Powołanie człowieka, tłum. i wstęp A. Zieleńczyk, Hachette, Warszawa 2010.

Fichte J.G., Teoria wiedzy. Wybór pism, t. 1, wybór, tłum., wstęp i oprac. M.J. Siemek, aneks tłum. J. Garewicz, PWN, Warszawa 1996.

Gilson E., Byt i istota, tłum. P. Lubicz, J. Nowak, Instytut Wydawniczy PAX, Warszawa 1963.

Hegel G.W.F., Fenomenologia ducha, tłum. A. Landman, PWN, Warszawa 1963.

Hegel G.W.F., Pisma wczesne z filozofii religii, tłum. G. Sowiński, Znak, Kraków 1999.

Hegel G.W.F., Wykłady z historii filozofii, t. III, tłum. i przypisy Ś.F. Nowicki, PWN, Warszawa 2002.

Hegel G.W.F., Wyktady z filozofii religii, t. 1, tłum. Ś.F. Nowicki, Wydawnictwo Naukowe PWN, Warszawa 2006.

Heidegger M., Der deutsche Idealismus (Fichte, Schelling, Hegel) und die philosophische Problemlage der Gegenwart, Gesamtaus- 
gabe, II. Abteilung: Vorlesungen 1919-1944, Bd. 28, Klostermann, Frankfurt am Main 1997.

Heidegger M., Kant a problem metafizyki, tłum. B. Baran, PWN, Warszawa 1989.

Herder J.G., Myśli o filozofii dziejów, t. I-II, tłum. J. Gałecki, wstęp i komentarz E. Adler, PWN, Warszawa 1962.

Kant E., Krytyka czystego rozumu, tłum. R. Ingarden, PWN, Warszawa 1957.

Kant E., Krytyka praktycznego rozumu, tłum. i oprac. J. Gałecki, PWN, Warszawa 1984.

Kant E., Krytyka władzy sqdzenia, tłum. J. Gałecki, PWN, Warszawa 1986.

Kant E., Religia w obrębie samego rozumu, tłum., wstęp i przypisy A. Bobko, Znak, Kraków 1993.

Kant E., Uzasadnienie metafizyki moralności, tłum. M. Wartenberg, PWN, Warszawa 1984.

Plotyn, Enneady, tłum. A. Krokiewicz, Akme, Warszawa 2000-2004.

Reinhold K.L., Versuch einer neuen Theorie des menschlichen Vorstellungsvermögens, 1789, hrsg. von E.-O. Onnasch, 1. Teilband, Felix Meiner Verlag, Hamburg 2010.

Reinhold K. L., Gesammelte Schriften, Kommentierte Ausgabe, hrsg. von M. Bondeli, Schwabe-Verlag, Basel 2007.

Rilke R.M., Elegie duinejskie. Sonety do Orfeusza, tłum. A. Lam, Dom Wydawniczy ELIPSA, Warszawa 2011.

Schelling F.W.J., Filozofia objawienia: ujęcie pierwotne, tłum. K. Krzemieniowa, Wydawnictwo Naukowe PWN, Warszawa 2002.

\section{Opracowania}

Althaus P., Die letzten Dinge. Entwurf einer christlichen Eschatologie, C. Bertelsmann, Gütersloh 1922.

Baron A., Neoplatońska idea Boga a ewangelizacja. Analiza anonimowego komentarza do „Parmenidesa” Platona na tle myśli plotyńsko-porfiriańskiej, WAM, Kraków 2005. 
$234 \quad$ Hans Urs von Balthasar wobec idealizmu niemieckiego

Beierwaltes W., Platonizm $w$ chrześcijaństwie, tłum. P. Domański, Wydawnictwo Antyk, Kęty 2003.

Bobko A., Kant i Schopenhauer: między racjonalnościq a nicościa, Wydawnictwo Wyższej Szkoły Pedagogicznej, Rzeszów 1996.

Bobko A., Myślenie wobec zła. Polityczny i religijny wymiar myślenia w filozofii Kanta i Tischnera, Instytut Myśli Józefa Tischnera, Uniwersytet Rzeszowski, Kraków-Rzeszów 2007.

Bondeli M., Das Anfangsproblem bei Karl Leonhard Reinhold. Eine systematische und entwicklungsgeschichtliche Untersuchung zur Philosophie Reinholds in der Zeit von 1789 bis 1803, V. Klostermann, Frankfurt am Main 1995.

Gadacz T., Wolność a odpowiedzialność. Rosenzweiga i Levinasa krytyka heglowskiej wolności ducha, Wydawnictwo Naukowe PAT, Kraków 1990.

Hartmann N., Die Philosophie des deutschen Idealismus, BerlinNew York $1974^{3}$.

Heinrich D., Grundlegung aus dem Ich. Untersuchungen zur Vorgeschichte des Idealismus, Tübingen-Jena 1790-1794, Suhrkamp, Frankfurt 2004.

Hirsch E., Geschichte der neueren evangelischen Theologie im Zusammenhang mit den allgemeinen Bewegungen des europäischen Denkens, Bd. 4, C. Bertelsmann, Gütersloh 1952.

Historisches Wörterbuch der Philosophie, hrsg. von J. Ritter, K. Gründer, Bd. 4, Basel-Stuttgart 1976.

Kronenberg M., Geschichte des deutschen Idealismus, Bd. 1: Die idealistische Ideen-Entwicklung von ihren Anfängen bis Kant, Oskar Beck, München 1909; Bd. 2: Die Blütezeit des deutschen Idealismus. Von Kant bis Hegel, Oskar Beck, München 1912.

Kroner R., Von Kant bis Hegel, 2 Bde, Mohr Siebeck, Tübingen $1977^{3}$. Lauth R., Die Entstehung von Schellings Identitätsphilosophie in der Auseinandersetzung mit Fichtes Wissenschaftslehre: (17951801), Alber, Freiburg im Breisgau-München 1975. 
Noras A.J., Kant a neokantyzm badeński i marburski, Wydawnictwo Uniwersytetu Śląskiego, Katowice 2005.

Przyłębski A., Duch czy życie? Studia i szkice z filozofii niemieckiej, Wydawnictwo Naukowe WNS UAM, Poznań 2011.

Rocca E., Die Wahrnehmung des Glaubens. Kierkegaards Dimis-Predigt und die „Philosopischen Brocken”, „Kierkegaard Studies” 2004, ed. N.J. Cappelørn, H. Deuser, J. Stewart, Berlin-New York 2004, s. 18-38.

Rocca E., Tra estetica e teologia. Studi kierkegaardiani, Edizioni ETS, Pisa 2004.

Siemek M.J., Hegel i filozofia, Oficyna Naukowa, Warszawa 1998.

Siemek M.J., Idea transcendentalizmu u Fichtego i Kanta. Studium $z$ dziejów filozoficznej problematyki wiedzy, PWN, Warszawa 1977.

Siep L., Praktische Philosophie im Deutschen Idealismus, Suhrkamp, Frankfurt 1992.

Strumiłowski J.P., Piękno zbawi świat?, WAM, Kraków 2016.

Tilliette X., Rescherches sur l'intuition intellectuelle de Kant à Hegel, Librairie Philosophique J. Vrin, Paris 1995.

Urban M., Rozpacz tożsama z estetyka?, w: Człowiek wobec rozpaczy $w$ filozofii Sørena Kierkegaarda, red. M. Urban, W. Zuziak, Wydawnictwo Naukowe PAT, Kraków 2004.

Ziemiński I., Życie wieczne. Przyczynek do eschatologii filozoficznej, W Drodze, Poznań-Kraków 2013.

Żelazny M., Heglowska filozofia ducha, Wydawnictwo IFiS PAN, Warszawa 2000. 
- 


\section{Resume}

The debate between Christianity and philosophical thought is still topical and constitutes a part of the contemporary dispute about the proper image of the world as well as the most important issues concerned with the coexistence of various world views and religions. Hans Urs von Balthasar's deliberations on German idealism fall within the scope of this discussion about the state of Christian thought. Von Balthasar's reasoning arises out of concern for the understanding of the religious and intellectual image of the history of Europe, and creates space for a proper perception of the tasks for philosophy itself. Already at the beginning of his activity Balthasar found the links between philosophical thought and Christian ideas fascinating. $\mathrm{He}$ realised that the maintenance of mutual, dialectical relationships poses a challenge to all philosophy. Deliberations on German idealism constitute an introduction to the method and structure of Balthasar's comprehensive reasoning, which encompasses both his philosophical and theological activity. They can also be helpful in understanding the fundamental lines of the development of his activity, seen as a whole from the viewpoint of theological a priori, pervading and reinforcing all his literary and philosophical reasoning. 
Struggling through the intricacies of literature caused Balthasar to ask the question about the stance that great representatives of the German culture take on the Christian heritage, as well as afforded a new view of the great figures of the German philosophy, who would become stars shedding light on profound and broad comprehensive reasoning. The first look at philosophical idealism was not only intended as a descriptive, neutral depiction of views of a number of thinkers, but bore a clear trait of judgment and critical thought. The judgment pointed to the ultimate failure of all thought of a purely immanent character. Creative development of the world should above all be seen as a movement expressing an internal transcending capability, which is an essential point in the human nature. It ought to depict the fundamental objective of a human being: the ultimate form of a personal being justified in the absolute being - God. In contemporary reasoning Balthasar saw a tendency to approach the history of European thought and its development in a way abounding in contradictions. The development takes on a dialectical character; negatively construed occurrences become positively significant for the future.

This book reveals the origins and context of Hans Urs von Balthasar's philosophical activity, arising out of the existential experience of a man living in the world as well as out of the profound belief in the necessity to consider the activity with regard to religious thought. It also contains a description of the relationships between idealist views and Christian reflection in German literature, discussed by the Swiss thinker mainly in Apokalypse der deutschen Seele. He views the development of the German philosophy of spirit through the philosophical and historical prism, and presents more than 700 years of the German spiritual life from the Christian perspective. Balthasar casts aside aspirations that tend to see the world through the prism of the 
subject's own activity only, and searches for possibilities for steering the intellect onto the ways leading to what is transcendent, so as to find anew the lost desire for the unity of the world. Since idealist reasoning arises out of Kant's terms and speculation, von Balthasar agrees with the proposition that it was the Kantian concept of the critique of reason that led to the emergence of the speculative systems of Fichte, Schelling and Hegel. The problem with the comprehension of the idealist systems of these three philosophers shows to what extent they influenced Balthasar's thought and how he interpreted them. The dialectical tension between philosophical reflection and Christian thought is above all presented in the analysis of Hegel's thought.

The rationale behind this book is thus to understand Balthasar's attitude to German idealism in the context of the whole of his philosophical and religious thought. Coming face to face with German idealism allowed him to reveal the weight of both the philosophical reason and the reflection on the faith he lived by. Their mutual relationship can be portrayed with the aid of a human figure characterised by Promethean qualities courage and sacrifice. Balthasar's attitude to German idealism is ambivalent. On the one hand, his view of it is very positive, and he even clearly yields to the influence of its fundamental ideas. On the other hand, he distinctly dissociates himself from it, subjecting even its principal goals to critique. This attitude appears not to have been thoroughly analysed so far. In a number of research papers on the philosophical elements in Balthasar's activity and their influence on theological reasoning, German idealism is frequently mentioned as the original and pivotal point in the entirety of the author's thought. The weight of this issue features a historical aspect, for it constitutes a vital beginning of Balthasar's creative reasoning, as well as a subject matter aspect, 
for it reveals an essential problem of the relationship between man and God, which can be traced throughout his activity.

The starting point for the deliberation on idealism, in such an ambivalent context, is the attention paid to the category of beauty, which to Balthasar's mind appears to have sunk deep into oblivion - both in exact sciences and in the humanities, and above all in religion and theology. The attempt to restore the beauty to its significance should be made by philosophy, for which it is not so much a starting point for deliberation, but rather the termination point. Balthasar is convinced that in the world devoid of beauty man can neither pray, nor love. Man cannot discern good, and since he cannot discern it, he will not be able to turn it into reality. Ultimately, becoming oblivious to beauty leads to becoming oblivious to being. Human existence remains murky and incomprehensible. The task of a thinking man is to make the effort to restore the mystery of human existence. Hence, he must come to understand that he is no longer capable of certain tasks, or he must ignore the knowledge of his lack of own capabilities and understand that the time has come again to discern the truth about the whole, which is a living bond between God and the world.

Balthasar considers that it is actually a specific kind of religious aestheticism that continually added life to German idealism, and thanks to it the latter offered dynamic thinking about the world. The aesthetic and religious realities fall within the atmosphere of the German Romanticism. The very aesthetic and religious experience reveals a fundamental philosophical problem of the German idealism: a presentiment of the infinite.

True Christian philosophy was supposed to live by the passion of the divine Logos and thus restore the secularised theological matter to its real form. Hence, Balthasar shows German idealism 
from a religious perspective. It is however confronted with the perspective of modern thinking, which, along with Kant, turns eschatological metaphysics into transcendental eschatology. It desires man to be standing at the very centre, where he would be subject to temporality, and therefore to becoming. Because of this, there happens to be some kind of a shift in eschatological deliberations from the Absolute to the finite being, which is man in the world.

If German idealism sees the origin of religious deliberation in the neoplatonic tradition, Balthasar's assessment is by all means positive. But when the same idealism - with a view to understanding that which is unconditioned - turns to transcendental philosophy, which is the one which attempts to limit itself within the bounds of the finite being, and by extension within the experience of the beauty of an anthropological character, Balthasar - if not short of its rejection - dissociates himself from it. He describes man's attitudes presented in literature, art, philosophy and theology, not only on account of a purely historical, neutral interest, but also having in mind a critical look at man's ability to open up to transcendence, and thus he shows a necessity of objectifying these attitudes. Opening up to eschaton, to that which is ultimate, becomes a man's fundamental task.

Balthasar's critical look at idealism should be understood as criticism levelled from the inside. Revealing the ultimate goal is first and foremost possible in the approach to a specific occurrence, a life of a specific subject, and not in the abstract approach of "objective" data on some kind of an occurrence. Balthasar's judgment was to be concerned with pointing to an ultimate failure of all thought of a purely immanent character. Ultimately, the eschatological attitude of the German soul will be perceived as a tragedy. If man, and alongside him all that is 
finite being, cannot in his attitude reach the infinite, the infinite element must somehow and on its own give itself to that which is finite. Such thinking requires some preliminary assumption. God as eschaton, giving himself and anticipating any attitude, appears as the fundamental thought in Balthasar's eschatology. Balthasar is convinced that German idealism should be overcome, but at the same time preserved. It should be preserved, for it sets the beginning of the proper spiritual path into the future. Eventually, Balthasar's approach leads to reversing the historical order of the idealist thought. Man's infinite spirit should at all cost try and approach that which is infinite, but God as the eschaton, who justifies and builds all, is the starting point. 


\section{Zusammenfassung}

Die Diskussion zwischen dem Christentum und dem philosophischen Denken ist nach wie vor aktuell und bildet zweifellos einen wichtigen Teil der gegenwärtigen Auseinandersetzung über das richtige Weltbild und über die wichtigsten Fragen des Nebeneinanders von verschiedenen Weltanschauungen und Religionen. Zu dieser Diskussion über den Stand des christlichen Denkens gehören die Betrachtungen von Hans Urs von Balthasar zum deutschen Idealismus. Sie entspringen der Balthasarschen Sorge um das Verständnis des religiösen und intellektuellen Bildes der europäischen Geschichte und bilden den Raum für das richtige Begreifen der Aufgaben der Philosophie selbst. Die Verbindungen der Philosophie und der Ideen des Christentums faszinierten von Balthasar bereits am Anfang seiner Tätigkeit. Er war sich bewusst, dass es eine große Herausforderung für die ganze Philosophie ist, ihre gegenseitigen, dialektischen Beziehungen aufrechtzuerhalten. Die Betrachtungen von Balthasar zum deutschen Idealismus bilden die Einführung in die Methode und Struktur seines ganzen Denkens, das sich sowohl in seinem philosophischen als auch theologischen Schaffen ausdrückt. Sie können auch helfen, die Hauptrichtungen in der Entwicklung seines Werkes im Lichte 
des theologischen a priori zu verstehen, das sein ganzes literarisch-philosophisches Denken durchdringt und prägt.

Von Balthasars Kämpfen durch das Dickicht der Literatur stellte ihn vor die Frage nach der Einstellung der großen Vertreter der deutschen Kultur zum christlichen Erbe. Es ermöglichte ihm zugleich einen neuen Blick auf die wichtigen Gestalten der deutschen Philosophie - auf jene Sterne also, deren Licht das tiefe und breite Gesamtdenken beleuchtet. Die ersten Betrachtungen über die idealistische Philosophie, deren Ziel es nicht war, ausschließlich die Ansichten der einzelnen Denker zu beschreiben und neutral darzustellen, haben einen deutlich urteilenden und kritischen Charakter. Dieses Urteil deutete auf das endgültige Scheitern des rein immanent geprägten Denkens hin. Die kreative Entwicklung der Welt sollte in erster Linie als eine die innere Fähigkeit des Transzendierens ausdrückende Bewegung sichtbar werden, die das Wesentlichste der menschlichen Natur ausmacht. Dieses Transzendieren sollte das fundamentale Ziel des Menschen erscheinen lassen: die letzte Gestalt des personalen Seins, das seine Begründung im absoluten Sein, d.h. in Gott hat. In den modernen Ansichten sah von Balthasar eine gewisse Neigung zur widerspruchsvollen Auffassung von Geschichte und Entwicklung des europäischen Denkens. Diese Entwicklung nimmt einen dialektischen Charakter an; den als negativ wahrgenommenen Ereignissen wird eine positive Bedeutung für die Zukunft verliehen.

Das vorliegende Buch zeigt die Quellen und den Kontext des philosophischen Schaffens Hans Urs von Balthasars, das sich aus der existenziellen Erfahrung eines in der Welt lebenden Menschen sowie aus der tiefen Überzeugung ergibt, dieses Schaffen notwendig in Bezug auf das religiöse Denken betrachten zu müssen. Es enthält auch eine Beschreibung der Beziehungen zwischen den 
idealistischen Ansichten und der christlichen Reflexion in der deutschen Literatur, die von dem Schweizer Denker hauptsächlich in seinem Werk Apokalypse der deutschen Seele besprochen wurden. Durch das philosophisch-historische Prisma sieht er die Entwicklung der deutschen Philosophie des Geistes und präsentiert aus der christlichen Perspektive über 700 Jahre des deutschen Geisteslebens. Von Balthasar lehnt jene Bestrebungen ab, die die Welt nur im Hinblick auf die eigene Aktivität des Subjekts sehen möchten, und sucht nach Möglichkeiten, die Vernunft auf Wege zu leiten, die zum Transzendenten führen, um das verlorene Bedürfnis nach der Einheit der Welt von neuem zu finden. Da das idealistische Denken den Begriffen und Spekulationen Kants entspringt, stimmt von Balthasar der These zu, dass gerade das Kantsche Konzept der Kritik der Vernunft zur Entstehung der spekulativen Systeme von Fichte, Schelling und Hegel führte. Das Problem mit dem Verständnis der idealistischen Systeme dieser drei Philosophen zeigt, inwieweit sie das Denken von Balthasars beeinflussten und wie sie von ihm interpretiert wurden. Die dialektische Spannung zwischen der philosophischen Reflexion und dem christlichen Denken wurde vor allem in der Analyse der Ansichten Hegels präsentiert.

Das Ziel des Buches ist es also, das Verhältnis von Balthasars zum deutschen Idealismus im Zusammenhang mit seinem ganzen philosophischen und religiösen Denken zu verstehen. Die Auseinandersetzung mit dem deutschen Idealismus ließ ihn die Wichtigkeit sowohl der philosophischen Vernunft, als auch der Reflexion über den gelebten Glauben zeigen. Die gegenseitige Beziehung der beiden wird durch die Gestalt des Menschen mit prometheischen Charaktereigenschaften von Mut und Hingabe dargestellt. Das Verhältnis von Balthasars zum deutschen Idealismus ist ambivalent. Einerseits beurteilt er ihn sehr 
$246 \quad$ Hans Urs von Balthasar wobec idealizmu niemieckiego

positiv und steht sogar unter dem deutlichen Einfluss von dessen Hauptideen. Andererseits distanziert er sich aber evident davon und kritisiert selbst dessen grundlegende Ziele. Dieses Verhältnis scheint bis jetzt nicht genau analysiert worden zu sein. In vielen Bearbeitungen über die philosophischen Elemente im Schaffen von Balthasars und über ihren Einfluss auf sein theologisches Denken spricht man oft über den deutschen Idealismus als den ursprünglichen und zugleich entscheidenden Moment im Gesamtdenken des Autors. Die Frage hat einerseits einen historischen Aspekt, denn sie bildet den wesentlichen Anfang des kreativen Balthasarschen Schaffens, andererseits ist sie auch als inhaltlich wichtig zu betrachten, weil sie das grundlegende Problem der Beziehung des Menschen zu Gott darstellt, das in der ganzen Tätigkeit des Schweizers zu finden ist.

Der Ausgangspunkt für die Überlegungen zum Idealismus (in diesem ambivalenten Kontext) ist die Kategorie des Schönen, auf die von Balthasar besonders aufmerksam macht und die seiner Meinung nach vergessen wurde - sowohl von den Natur-, als auch den Geisteswissenschaften, vor allem aber von Religion und Theologie. Den Versuch, dem Schönen seine Bedeutung zurückzugeben, sollte die Philosophie unternehmen, für die es nicht den Ausgangspunkt, sondern eher das Ziel der Überlegungen bildet. Von Balthasar ist überzeugt, dass der Mensch in einer des Schönen beraubten Welt weder beten, noch lieben kann. Er ist dann auch nicht imstande, das Gute zu bemerken, und wenn er es nicht bemerkt, kann er es nicht verwirklichen. Das Schöne vergessen bedeutet letztendlich das Sein vergessen. Die menschliche Existenz bleibt düster und unverständlich. Die Aufgabe des denkenden Menschen ist es, sich die Mühe zu geben, das Geheimnis des menschlichen Daseins wiederherzustellen. Deshalb hat er zu verstehen, dass er zu manchen Aufgaben nicht mehr fähig ist, oder 
er muss das Wissen über den Mangel an eigenen Fähigkeiten ignorieren und begreifen, dass die Zeit gekommen ist, die Wahrheit des Ganzen, die die lebendige Bindung zwischen Gott und der Welt darstellt, wieder zu bemerken.

Von Balthasar meint, dass es eine Art vom religiösen Ästhetizismus war, die den deutschen Idealismus dauernd belebte, und dass er dadurch die Dynamik des Denkens über die Welt mit sich brachte. Beide Wirklichkeiten - die ästhetische und die religiöse - gehören natürlich auch zur Atmosphäre der deutschen Romantik. Die ästhetisch-religiöse Erfahrung selbst offenbart das philosophische Grundproblem des deutschen Idealismus: die Vorahnung des Unendlichen.

Die wahre christliche Philosophie sollte von der Leidenschaft zum göttlichen Logos leben und auf diese Weise die säkularisierten theologischen Inhalte zu ihrer echten Gestalt zurückholen. Deshalb zeigt von Balthasar den deutschen Idealismus aus der religiösen Perspektive. Sie wird aber mit der Perspektive des modernen Denkens konfrontiert, das zusammen mit Kant die eschatologische Metaphysik in die transzendentale umwandelt. Diese will den Menschen ins Zentrum stellen, der der Zeitlichkeit, und dadurch dem Werden unterworfen ist. Aus diesem Grund kommt es zur Verschiebung der eschatologischen Überlegungen vom Absoluten zum endlichen Sein, d.h. zum Menschen in der Welt.

Solange der deutsche Idealismus die Quelle des religiösen Denkens in der neuplatonischen Tradition sieht, beurteilt ihn von Balthasar positiv. Wenn aber derselbe Idealismus, um das Unbedingte zu verstehen, sich der transzendentalen Philosophie zuwendet, d.h. jener, die versucht, sich in den Grenzen des endlichen Seins (also in der Erfahrung des Schönen mit anthropologischem Charakter) einzuschließen, lehnt ihn von Balthasar zwar nicht völlig $a b$, distanziert sich aber davon. Er beschreibt 
die in Literatur, Kunst, Philosophie und Theologie dargestellten Haltungen des Menschen nicht nur aus rein historischem, neutralem Interesse, sondern um auf die menschliche Fähigkeit, sich der Transzendenz zu öffnen, kritisch zu blicken. Auf diese Weise zeigt er die Notwendigkeit, diese Haltungen zu objektivieren. Die Öffnung des Menschen auf das Eschaton, auf das Letzte, wird zu seiner fundamentalen Aufgabe.

Der kritische Blick von Balthasars auf den Idealismus ist als eine sozusagen von Innen durchgeführte Kritik zu verstehen. Das Offenbaren des Endziels wird vor allem im Zugang zu einem konkreten Ereignis, zum Leben eines konkreten Subjekts möglich, und nicht in der abstrakten Auffassung von „objektiven“ Daten über ein Geschehen. Das Balthasarsche Urteil sollte auf das endgültige Scheitern des rein immanenten Denkens hinweisen. Die eschatologische Haltung der deutschen Seele wird letztendlich als eine Tragödie eingeschätzt. Wenn nämlich der Mensch und mit ihm alles endliche Sein durch seine Haltung nicht das Unendliche erreichen kann, muss das unendliche Element sich in irgendeiner Weise dem Endlichen geben. Ein solches Denken verlangt eine Voraussetzung. Gott als Eschaton, das sich selbst hingibt und jede Haltung antizipiert, scheint der Hauptgedanke der Eschatologie von Balthasars zu sein. Er ist überzeugt, dass der deutsche Idealismus einerseits zu überwinden, andererseits aber zu erhalten ist. Zu erhalten, weil er den Anfang des richtigen geistigen Weges in die Zukunft markiert. Die Balthasarsche Auffassung führt letztendlich zur Umkehrung der historischen Ordnung des idealistischen Denkens. Der unendliche Geist des Menschen sollte um jeden Preis das Unendliche umfassen, Gott aber als Eschaton, das alles begründet und baut, ist der Ausgangspunkt. 


\section{Indeks nazwisk}

Adler, Alfred 39

Allers, Rudolf 38-39

Althaus, Paul 76

Anzelm, św. 38

Arystoteles 184

Augustyn, św. 177, 197

Bach, Jan Sebastian 219

Barth, Karl 41, 43-44, 59, 74, 178-179, 186

Bauer, Emmanuel J. 31, 35

Baumgarten, Alexander Gottlieb 174

Bergson, Henri 41, 54, 59, 74, 148

Bloch, Ernst 161

Bobko, Aleksander 31, 69

Boecjusz 181

Böhme, Jakub 22, 137, 146, 211

Bollnow, Otto Friedrich 64

Bondeli, Martin 92, 99

Bouillard, Henri 40
Cassierer, Ernst 101

Daniélou, Jean-Guenolé-Marie 40

Dostojewski, Fiodor 59, 73, 74

Duns Szkot, Jan 184-185

Eckhart von Hochheim 182, $185,187-188$

Eibl, Hans 39, 54

Empedokles 105

Eriugena, Jan Szkot 54, 150, 211

Faesi, Robert 60

Faust, August 14, 106, 164

Feuerbach, Ludwig 13, 96

Fichte, Johann Gottlieb 18, 21, $23,28,29,30,41,49$, $54,57,59,61,73,92$, 95, 97, 98-99, 100, 101102, 105-106, 108-124, 127, 134, 137, 148-150, 
$250 \quad$ Hans Urs von Balthasar wobec idealizmu niemieckiego

$152,156,159,162,164$, $168-170,180,188,189$, 197-200, 204, 215, 216, 217

Ficino, Marsilio 150

George, Stefan Anton 64, 74 Goethe, Johann Wolfgang von $12,14,15,18,30,40$, 49-50, 59, 61, 62, 74, $101,105,107,142,150$, $159,177,180,182,215$

Grzegorz z Nyssy 14, 40

Guardini, Roman 39

Gügler, Alois 20

Haas, Alois M. 64

Haecker, Theodor 64

Hamann, Johann Georg 77-78, 210

Hartmann, Nicolai 100

Haydn, Joseph 19

Hebbel, Christian Friedrich 13, 22, 59

Hegel, Georg Wilhelm Friedrich $13,14,18,21,22,28$, $29,41,50,53,57,62$, 74, 95-97, 98-99, 100101, 105-107, 118, 142, 143-166, 169, 171, 178, $180,182,185-186,188$, 189, 203-207, 211, 214, 215, 216
Heidegger, Martin 41, 43, 59, 74, 100, 177, 182, 215, 216

Henrici, Peter 31, 143, 149, 162

Herder, Johann Gottfried 13, 18, 22, 41, 59, 62, 73, 78-79, 85, 142, 150

Hirsch, Emanuel 132

Hofmannsthal, Hugo von 13, 40

Hölderlin, Johann Christian Friedrich, 13, 14, 18, 22, 40, 59, 61, 74, 105, 150, 156, 159, 177, 180, 207, 215

Homer 177, 181

Husserl, Edmund 47, 59, 74

Jacobi, Carl Gustav Jakob 125 Jaspers, Karl 214

Jean Paul (właśc. Johann Paul Friedrich Richter) 13, 59, 74, 105, 159

Kant, Immanuel 12, 13, 18, 21, 22, 28, 41, 49-50, 59, 62, 69, 73, 79-93, 95-97, 98-100, 101-102, 105107, 109, 112, 116, 134, $135,139,146,161,165$, 173, 178, 182, 185-186, 188, 189-197, 211, 217 
Kartezjusz (René Descartes) 151, 152, 182, 188

Kierkegaard, Søren 39, 41, 59, $63,73,96,178$

Klages, Ludwig 41, 74

Klopstock, Friedrich Gottlieb 77

Kronenberg, Moritz 99

Kroner, Richard 99

Leibniz, Gottfried Wilhelm 134, 152, 174, 182, 207

Lessing, Gotthold Ephraim 13, $18,59,61,73,77$

Löser, Werner 31, 48

Lubac, Henri de 40

Lukács, György 161

Luter, Marcin 22, 75

Marks, Karol 13, 96, 161, 207

Mahler, Gustav 39

Maksym Wyznawca 40

Maréchal, Joseph 39

Mendelssohn, Moses 142

Mikołaj z Kuzy (Kuzańczyk) 23, 54, 150, 181, 182, 213

Mozart, Wolfgang Amadeusz 19

Naduvilekut, James 48

Nietzsche, Fryderyk 13, 14, 22 , 40, 41, 59, 63, 74, 96, 214
Novalis 22, 26, 59, 61, 74, 105, 180,215

Orygenes 14, 40, 51

Platon 14, 177, 181, 184 Plotyn 23, 39, 54-57, 106, 109, 149, 150, 161, 173, 177, 185, 195, 212

Przywara, Erich 39-40, 43 Pseudo-Dionizy Areopagita 150, 197

Rahner, Karl 47, 49

Reinhold, Karl Leonhard 97-98 Rilke, Rainer Maria 13, 74, 157

Scheler, Max 13, 41, 49, 59, 74 Schelling, Friedrich Wilhelm Joseph von 18, 21, 28, 29, 30, 41, 54, 57, 59, 69, 73, 95-97, 98-99, 100, 101, 105, 124-142, 148-150, 159, 162, 166, 168-171, 177, 180, 188, 189, 200-203, 204, 206, 215-216

Schiller, Fryderyk 18, 25, 59, 74, 105, 135, 159, 178, 182, 189, 215

Schleiermacher, Friedrich

Daniel Ernst 180, 186

Schopenhauer, Arthur 96

Schulz, Michael 31, 143 
252 Hans Urs von Balthasar wobec idealizmu niemieckiego

Seewald, Richard 180

Simmel, Georg 49

Sokrates 105

Sołowjow, Wiktor 210

Sörgel, Herman 64

Spinoza, Baruch de 131, 148, $150,152,182$

Tasso, Torquato 14

Tomasz z Akwinu, św. 33, 38, $43,44,177,181,184$

Varillon, François 40

Wagner, Ryszard 13, 22, 59

Zinzendorf, Nikolaus Ludwig von 22

Żelazny, Mirosław 95 